\title{
Matematika előadások
}

'Everything should be made as simple as possible. But not simpler.' (A. Einstein)

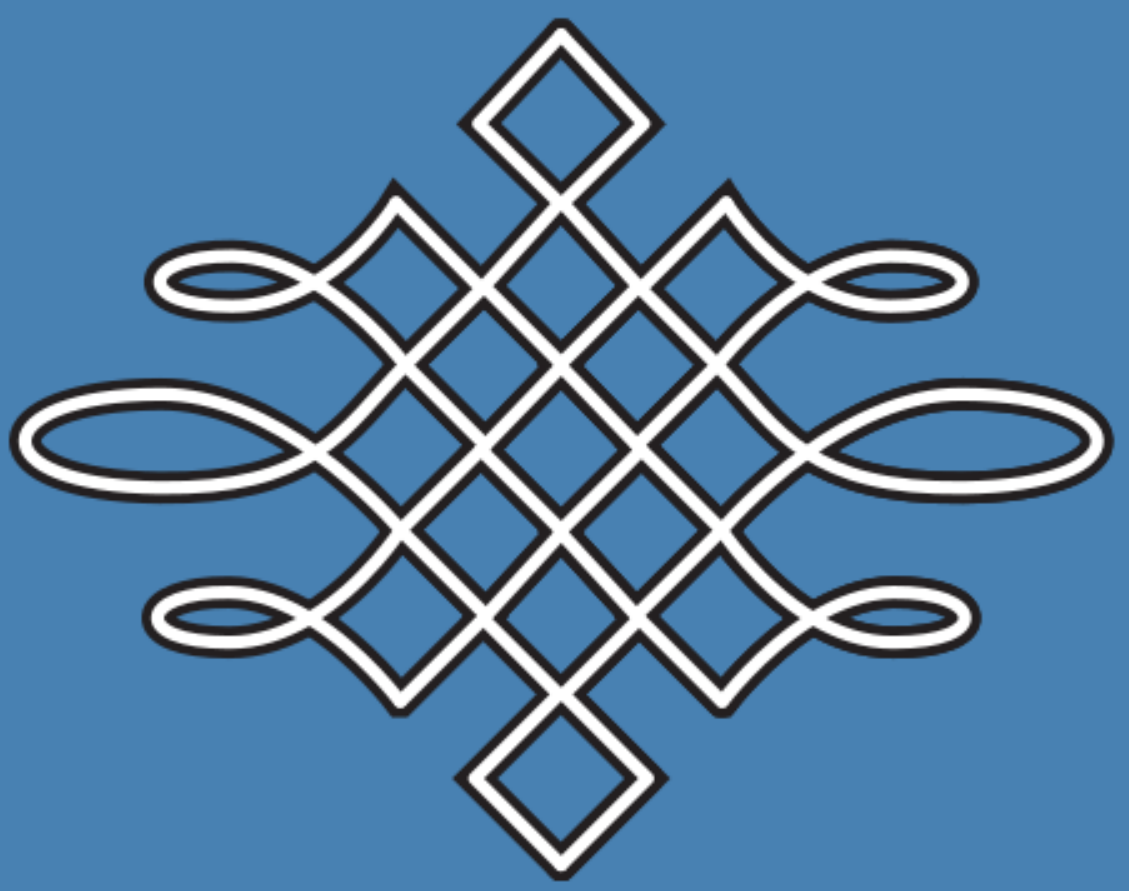

Szerző: TALLOS PÉTER

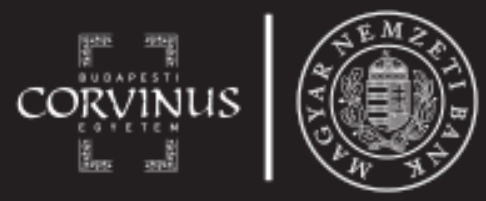


Matematika előadások

Budapest I 2018. 



\section{Tallos Péter}

\section{Matematika előadások}

Közgazdaságtudományi Kar

Matematika Tanszék 
Budapesti Corvinus Egyetem

Közgazdaságtudományi Kar

Matematika Tanszék

Cím:

Matematika előadások

Szerző:

(c) Tallos Péter

\section{Kiadó:}

Budapesti Corvinus Egyetem I 1093, Budapest, Fővám tér 8.

\section{Nyomdai kivitelezés:}

Komáromi Nyomda

ISBN 978-963-503-704-9, 978-963-503-708-7 (e-book)

DOI $10.14267 / \mathrm{cb} .2018 \mathrm{k} 01$

Budapest I 2018.

„A Budapesti Corvinus Egyetem és a Magyar Nemzeti Bank együttmúködési megállapodása keretében támogatott mú.”
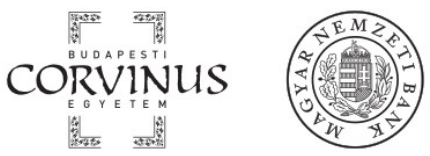


\section{TARTALOM}

\begin{tabular}{ll}
\hline Elószó & 11
\end{tabular}

I. Elsố félév: Differenciál és integrálszámítás 13

\begin{tabular}{llr}
\hline 1. & Sorozatok & 17
\end{tabular}

1.1. A határérték definicíoja . . . . . . . . . . . . . . . . . . . . 17

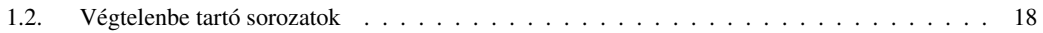

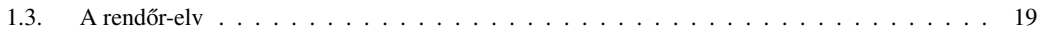

1.4. Korlátosság és monotonitás . . . . . . . . . . . . . . . . . . . . . . . . . . . . 19

1.5. Az Euler-féle $e$ szám . . . . . . . . . . . . . . . . . . . . . . . . . . . . 21

\begin{tabular}{lll}
\hline 2. Végtelen sorok & $\mathbf{2 5}$
\end{tabular}

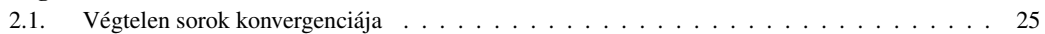

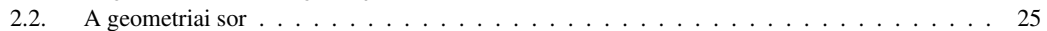

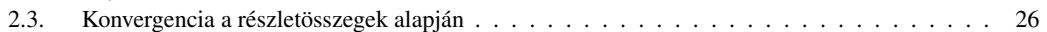

2.4. Feltételek konvergenciára $\ldots \ldots \ldots \ldots \ldots \ldots$

2.5. Abszolút konvergencia . . . . . . . . . . . . . . . . . . . . . . . . . . 28

2.6. Hányados-kritérium . . . . . . . . . . . . . . . . . . . . . . . . . . . . . . . . 29

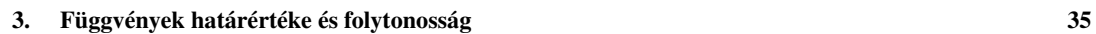

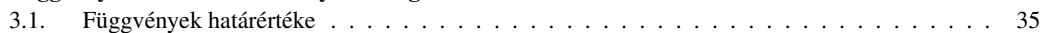

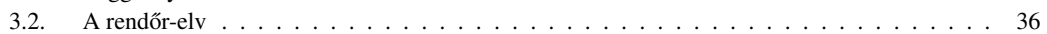

3.3. Egyoldali határérték . . . . . . . . . . . . . . . . . . . . . . . . . 37

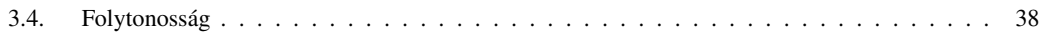

3.5. Folytonos függvények tulajdonságai $\ldots \ldots \ldots \ldots \ldots \ldots \ldots$

\begin{tabular}{lll}
\hline 4. & Függvények deriváltja & 43
\end{tabular}

$4.1 . \quad$ A derivált fogalma . . . . . . . . . . . . . . . . . . . . . . . . . 43

4.2. Görbék érintője . . . . . . . . . . . . . . . . . . . . . . . . . . 44

4.3. Differenciálási szabályok . . . . . . . . . . . . . . . . . . . . . . . 44

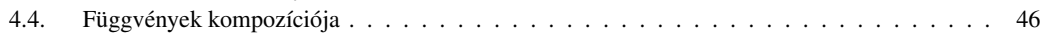

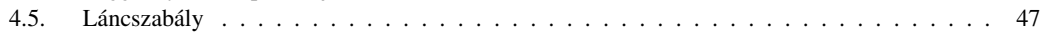

5. A középérték-tétel 51

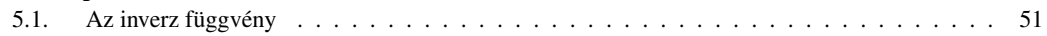

5.2. Az inverz függvény differenciálhatósága $\ldots \ldots \ldots \ldots \ldots \ldots \ldots$. . . . . . . . 51

5.3. Az exponenciális és a logaritmus függvény $\ldots \ldots \ldots \ldots \ldots \ldots$ 


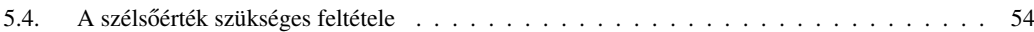

$5.5 . \quad$ Lagrange-féle középérték-tétel $\ldots \ldots \ldots \ldots \ldots \ldots \ldots \ldots$

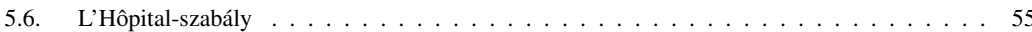

6. A teljes függvényvizsgálat 59

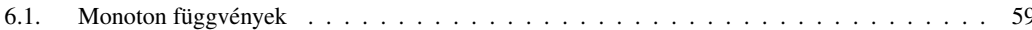

6.2. A szélsőértékhely megkeresése . . . . . . . . . . . . . . . . . . . . 60

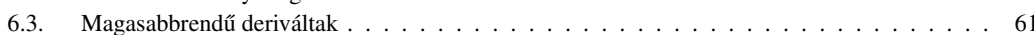

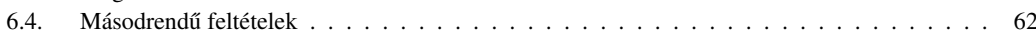

6.5 . Konvex és konkáv függvények . . . . . . . . . . . . . . . . . . . . . . 64

$\begin{array}{ll}\text { 7. Integrálás } & 69\end{array}$

7.1. A határozatlan integrál fogalma . . . . . . . . . . . . . . . . . . . . . . . . 69

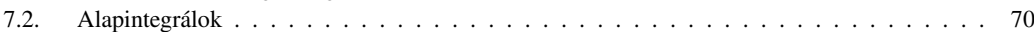

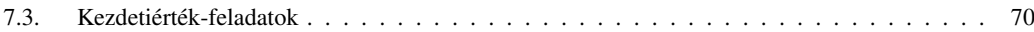

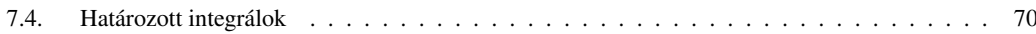

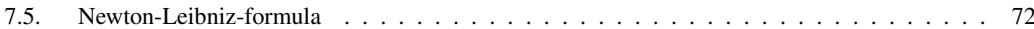

\begin{tabular}{lll}
\hline 8. Integrálási technikák & $\mathbf{7 7}$
\end{tabular}

8.1. Parciális integrálás . . . . . . . . . . . . . . . . . . . . . 77

8.2. Parciális integrálás határozott integrálokra . . . . . . . . . . . . . . . . . . . 77

8.3. Integrálás helyettesítéssel $\ldots \ldots \ldots \ldots \ldots \ldots \ldots \ldots$

8.4. Helyettesítés határozott integráloknál . . . . . . . . . . . . . . . . . . . . 80

8.5. Lineáris differenciálegyenlet $\ldots \ldots \ldots \ldots \ldots \ldots$. . . . . . . . . . . . . 80

\begin{tabular}{|l|l}
\hline 9z integrálás kiterjesztése & 85
\end{tabular}

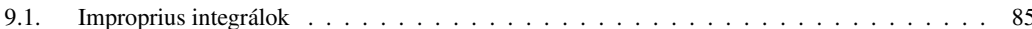

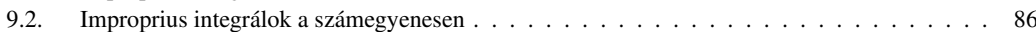

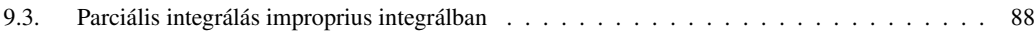

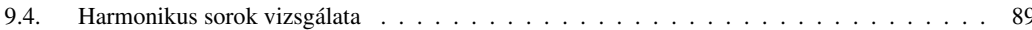

10. Hatványsorok 93

10.1. Hatványsorok összege . . . . . . . . . . . . . . . . . . . . . . . . . . . . . . . . . . . . . . . . 93

10.2. A konvergencia-sugár . . . . . . . . . . . . . . . . . . . . . . . . . . . . . . . . . . . . . . . . . 93

10.3. Hatványsor differenciálhatósága . . . . . . . . . . . . . . . . . . . . . . . . . . 95

10.4. Az együtthatók meghatározása . . . . . . . . . . . . . . . . . . . . . . . 96

10.5. Az exponenciális függvény hatványsora . . . . . . . . . . . . . . . . . . . . 97

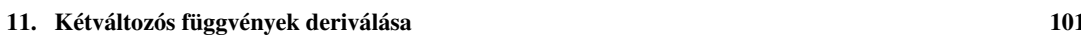

11.1. Parciális deriváltak . . . . . . . . . . . . . . . . . . . . . . . . 101

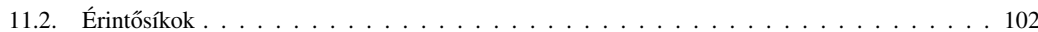

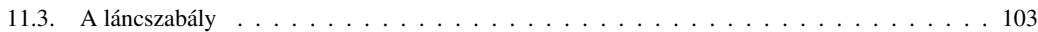

11.4. Lokális szélsőérték $\ldots \ldots \ldots \ldots$. . . . . . . . . . . . . . . . . . 104

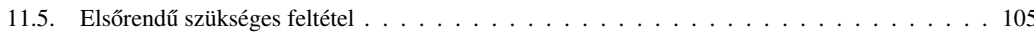

12. Feltételes szélsóérték 109

12.1. Implicit függvények $\ldots \ldots \ldots \ldots \ldots \ldots \ldots$

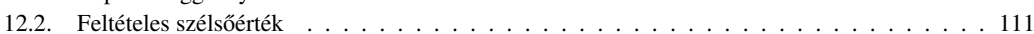

12.3. Lagrange-multiplikátorok . . . . . . . . . . . . . . . . . . . . . . . . 112

12.4. A szélsőérték-feladat megoldása . . . . . . . . . . . . . . . . . . . . . 113 
II. Második félév: Valószínúiségszámítás 115

\begin{tabular}{lr}
\hline 13. Valószínúség & 119
\end{tabular}

13.1. Kísérletek . . . . . . . . . . . . . . . . . . . . . . . . . 119

13.2. Az eseménytér . . . . . . . . . . . . . . . . . . . . . . . . . . . . 119

13.3. Események . . . . . . . . . . . . . . . . . . . . . . . . . . . 120

13.4. Mûveletek eseményekkel . . . . . . . . . . . . . . . . . . . . . . . . . 120

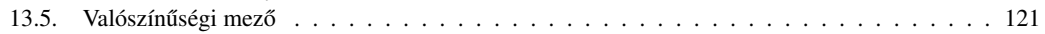

\begin{tabular}{lr}
\hline 14. Mintavételi eljárások & 127
\end{tabular}

14.1. Klasszikus valószínúségi mezôk . . . . . . . . . . . . . . . . . . . . . . . . . . 127

14.2. Mintavétel visszatevés nélkül . . . . . . . . . . . . . . . . . . . . . . . . . . . . . 129

14.3. Mintavétel visszatevéssel . . . . . . . . . . . . . . . . . . . . . . . . 130

14.4. A Bernoulli-kísérlet . . . . . . . . . . . . . . . . . . . . . . . . . 131

15. Feltételes valószínúség és Bayes-tétel 135

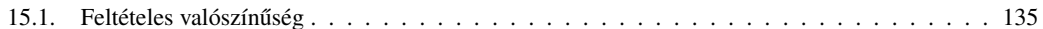

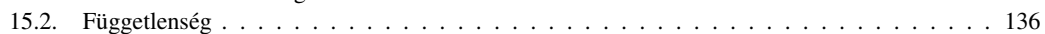

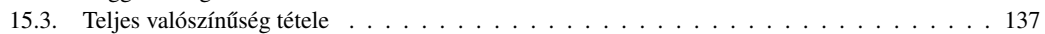

15.4. Bayes-tétel . . . . . . . . . . . . . . . . . . . . . . . . . . . 139

16. Valószínúségi változók és eloszlások 143

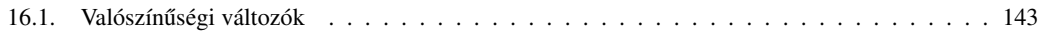

16.2. Diszkrét valószínúségi változó eloszlása . . . . . . . . . . . . . . . . . . . . . . . . . . . . 143

16.3. Az eloszlásfüggvény . . . . . . . . . . . . . . . . . . . . . . . . . . . . . . 144

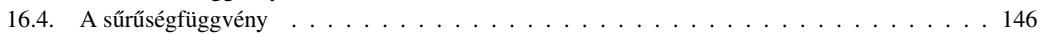

17. A várható érték és a szórás 151

17.1. Diszkrét eloszlások várható értéke . . . . . . . . . . . . . . . . . . . . 151

17.2. Végtelen elemú eloszlások várható értéke . . . . . . . . . . . . . . . . . . . . . . . . . . 152

17.3. Folytonos eloszlások várható értéke . . . . . . . . . . . . . . . . . . . . . . 153

17.4. A várható érték tulajdonságai . . . . . . . . . . . . . . . . . . . . . . . . . . . . 154

17.5. A variancia és a szórás . . . . . . . . . . . . . . . . . . . . . . . 155

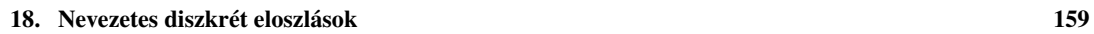

18.1. Karakterisztikus eloszlás. . . . . . . . . . . . . . . . . . . . . . . . . . . 159

18.2. Binomiális eloszlás . . . . . . . . . . . . . . . . . . . . . . . . . . . 159

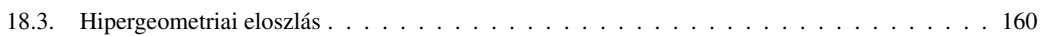

18.4. Geometriai eloszlás . . . . . . . . . . . . . . . . . . . . . . . . . . . . . 161

18.5. Poisson-eloszlás . . . . . . . . . . . . . . . . . . . . . . . . . . 162

\begin{tabular}{lr}
\hline 19. & 167
\end{tabular}

19.1. Egyenletes eloszlás . . . . . . . . . . . . . . . . . . . . . . . . . . . . . . 167

19.2. Exponenciális eloszlás . . . . . . . . . . . . . . . . . . . . . . . 168

19.3. A standard normális eloszlás . . . . . . . . . . . . . . . . . . . . . . . . . . . . . 169

19.4. Normális eloszlás . . . . . . . . . . . . . . . . . . . . . . . . . . . . 171

\begin{tabular}{lr}
\hline 20. Együttes eloszlások & 175
\end{tabular}

20.1. Együttes eloszlásfüggvény . . . . . . . . . . . . . . . . . . . . . . . . . 175

20.2. Diszkrét együttes eloszlások . . . . . . . . . . . . . . . . . . . . . . . . 175

20.3. Folytonos együttes eloszlások . . . . . . . . . . . . . . . . . . . . . 176

20.4. Függetlenség . . . . . . . . . . . . . . . . . . . . . . . 178 
20.5. Feltételes eloszlások … . . . . . . . . . . . . . . . . . . . . . . 179

21. Kovariancia és korreláció 183

21.1. Összeg várható értéke . . . . . . . . . . . . . . . . . . . . . . . . . . . . 183

21.2. Szorzat várható értéke . . . . . . . . . . . . . . . . . . . . . . . . . . . . . . . . 184

21.3. Összeg varianciája . . . . . . . . . . . . . . . . . . . . . . . . . . . . . . . . . 184

21.4. Kovariancia és korreláció . . . . . . . . . . . . . . . . . . . . . . . . . . 185

21.5. Teljes várható érték tétel . . . . . . . . . . . . . . . . . . . . . . . . . 187

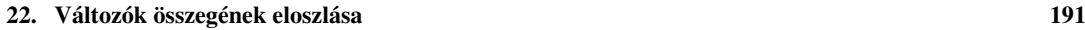

22.1. Diszkrét változók összegének eloszlása . . . . . . . . . . . . . . . . . . . . . . . 191

22.2. Folytonos változók összegének eloszlása . . . . . . . . . . . . . . . . . . . . . . . . . . 191

22.3. A Poisson-folyamat . . . . . . . . . . . . . . . . . . . . . . . . . . . 193

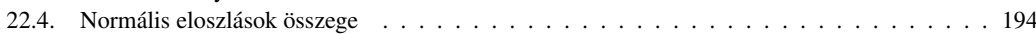

22.5. Centrális határeloszlás-tétel . . . . . . . . . . . . . . . . . . . . . . . . 195

23. A nagy számok törvénye 199

23.1. Csebisev-egyenlőtlenség. . . . . . . . . . . . . . . . . . . . . . . . . . . . 199

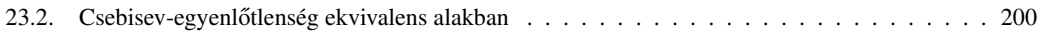

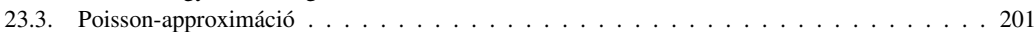

23.4. Nagy számok törvénye. . . . . . . . . . . . . . . . . . . . . . . . . 202

$\begin{array}{lr}\text { 24. A statisztika nevezetes eloszlásai } & \mathbf{2 0 7}\end{array}$

$24.1 . \quad$ Kétdimenziós normális eloszlás . . . . . . . . . . . . . . . . . . . . . . . . . . . . . . . . 207

24.2. Korrelálatlan normális eloszlások . . . . . . . . . . . . . . . . . . . . . . . . . 208

$24.3 . \quad$ Normálisból származtatott eloszlások . . . . . . . . . . . . . . . . . . . . . . . . . 208

24.4. A $\chi^{2}$-eloszlás, a $t$-eloszlás és az $F$-eloszlás . . . . . . . . . . . . . . . . . . . 210

III. Harmadik félév: Lineáris algebra 211

25. Vektorterek és alterek $\quad 215$

25.1. Az $\mathbb{R}^{n}$ vektortér . . . . . . . . . . . . . . . . . . . . . . . . . . 215

$25.2 . \quad$ Alterek . . . . . . . . . . . . . . . . . . . . . . . . . . . . . . 216

25.3. Generált altér . . . . . . . . . . . . . . . . . . . . . . . . . . . . . . . . 217

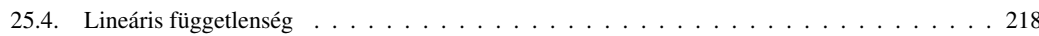

26. Lineáris függetlenség és bázis $\quad 223$

26.1. Generátorrendszer . . . . . . . . . . . . . . . . . . . . . . . 223

$26.2 . \quad$ Bázis . . . . . . . . . . . . . . . . . . . . . . . . . . . . . . . . . . . 224

$26.3 . \quad$ Dimenziól. . . . . . . . . . . . . . . . . . . . . . . . . . . . . . 225

26.4. Elemi bázistranszformáció . . . . . . . . . . . . . . . . . . . . . . . . . . . . . 226

27. Lineáris leképezések és mátrixok 231

27.1. Lineáris leképezések . . . . . . . . . . . . . . . . . . . . . . . . . . . . . . . . 231

27.2. Leképezések mátrixa. . . . . . . . . . . . . . . . . . . . . . . . . 232

27.3. Mátrix rangja és szabadságfoka . . . . . . . . . . . . . . . . . . . . 233

27.4. Mátrixok szorzása . . . . . . . . . . . . . . . . . . . . . . . . . . . . . . . . 235

\begin{tabular}{|r|r|}
\hline 28. & Lineáris egyenletrendszerek
\end{tabular}

28.1. Homogén lineáris egyenletrendszerek . . . . . . . . . . . . . . . . . . . . . . . . . . 239 
28.2. Inhomogén lineáris egyenletrendszerek . . . . . . . . . . . . . . . . . . . . . . . 240

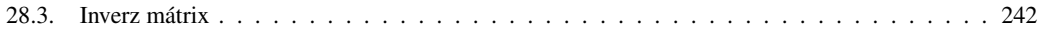

$28.4 . \quad$ Az inverz mátrix meghatározása . . . . . . . . . . . . . . . . . . . . . . . . . . . . . 244

\begin{tabular}{lr}
\hline 29. & 249
\end{tabular}

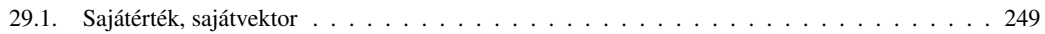

29.2. Sajátaltér . . . . . . . . . . . . . . . . . . . . . . . 250

29.3. Sajátvektorok meghatározása . . . . . . . . . . . . . . . . . . . . . 251

29.4. Lineárisan független sajátvektorok . . . . . . . . . . . . . . . . . . . . . . . . . . . . . . . . . . . . 251

29.5. Transzformációk diagonális alakja . . . . . . . . . . . . . . . . 252

\begin{tabular}{ll}
\hline 30. & $\mathbf{2 5 7}$
\end{tabular}

30.1. Permutációk . . . . . . . . . . . . . . . . . . . . . . . . 257

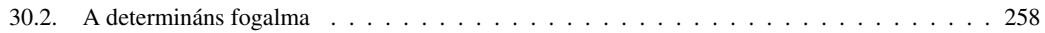

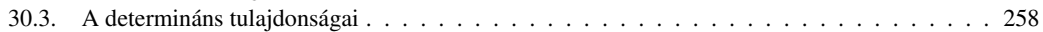

30.4. A determináns kiszámítása . . . . . . . . . . . . . . . . . . . . . . . . . . . . 260

30.5. Sajátértékek meghatározása . . . . . . . . . . . . . . . . . . . . . . . 261

\begin{tabular}{lr}
\hline 31. Skaláris szorzat & 265
\end{tabular}

31.1. Skaláris szorzat . . . . . . . . . . . . . . . . . . . . . . 265

31.2. Vektorok szöge, merôlegesség. . . . . . . . . . . . . . . . . . . 265

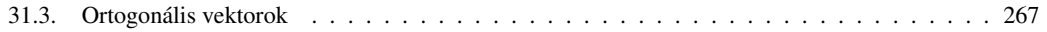

31.4. Gram-Schmidt-féle eljárás . . . . . . . . . . . . . . . . . . . . . . 268

31.5. Az ortogonális komplementer . . . . . . . . . . . . . . . . . . . . . . . . 268

$\begin{array}{lr}\text { 32. A spektráltétel } & 273\end{array}$

32.1. Transzponált mátrix . . . . . . . . . . . . . . . . . . . . . . . . . . 273

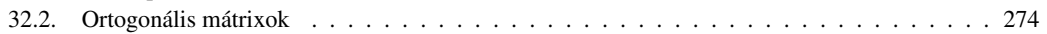

32.3. Szimmetrikus mátrixok . . . . . . . . . . . . . . . . . . . . . . . 275

32.4. Szimmetrikus mátrixok spektráltétele . . . . . . . . . . . . . . . . . . . . . 276

\begin{tabular}{lr}
\hline 33. Kvadratikus alakok & 281
\end{tabular}

$33.1 . \quad$ Kvadratikus alakok . . . . . . . . . . . . . . . . . . . . . . 281

33.2. Kvadratikus alak mátrixa . . . . . . . . . . . . . . . . . . . . . . . . . . 282

33.3. Kvadratikus alakok definitsége . . . . . . . . . . . . . . . . . . . . . . . . 283

33.4. Teljes négyzetté alakítás . . . . . . . . . . . . . . . . . . . . . . . . . . . . . . . . 284

33.5. Definitség a sajátértékek alapján. . . . . . . . . . . . . . . . . . . . . 285

34. Többváltozós függvények deriválása 289

34.1. Differenciálhatóság . . . . . . . . . . . . . . . . . . . . . . . . . . . . . 289

34.2. Láncszabály . . . . . . . . . . . . . . . . . . . . . . . . . . . . . . . 291

34.3. Parciális deriváltak . . . . . . . . . . . . . . . . . . . . . . 292

34.4. A Jacobi-mátrix és a gradiens . . . . . . . . . . . . . . . . . . . . . . . . . . 293

$\begin{array}{lr}\text { 35. Másodrendú deriváltak } & 299\end{array}$

35.1. Folytonos differenciálhatóság . . . . . . . . . . . . . . . . . . . . . . . . . . . 299

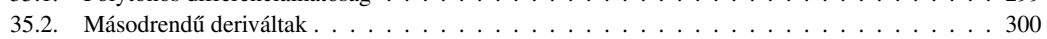

$35.3 . \quad$ Young-tétel . . . . . . . . . . . . . . . . . . . . . . . . . 301

35.4. Taylor-formula . . . . . . . . . . . . . . . . . . . . . . . 302

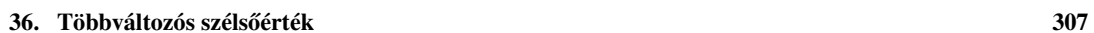

36.1. Lokális szélsőérték . . . . . . . . . . . . . . . . . . . . . . . . . . 307 


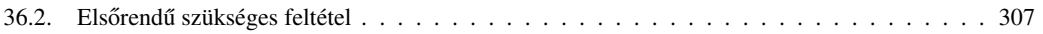

36.3. Másodrendú szükséges feltétel ． . . . . . . . . . . . . . . . . . . . . . . 308

36.4. A szélsóérték elégséges feltétele. . . . . . . . . . . . . . . . . . . . . . . . . . . . . . . 309

36.5. A szélsóérték meghatározása . . . . . . . . . . . . . . . . . . . . . . . . . . . . . 309 


\section{Előszó}

Ez a tankönyv a Budapesti Corvinus Egyetem Alkalmazott közgazdaságtan alapszakának matematika tananyagát tartalmazza. Igyekszünk minden olyan matematikai fogalmat és eljárást bemutatni, amely a mikroökonómia, makroökonómia, statisztika tárgyakban előfordul, illetve felhasználásra kerül, továbbá biztos alapokat ad további haladó szintû közgazdaságtani tárgyak elsajátításához. Ezek a témakörök az egyváltozós analízis, a valószínúségszámítás elemei, a lineáris algebra, és a többváltozós szélsőérték.

Az esetek többségében kerüljük az aprólékos bizonyításokat. Azokon a helyeken azonban, ahol ez segít a mélyebb megértésben és a készség kialakításában, megkíséreljük a tételeinket és állításainkat intuitív (és nem teljesen preciz) indoklással alátámasztani. Hangsúlyt helyezünk ugyanakkor a definíciók pontos megfogalmazására.

A megtárgyalt anyagrészeket bőséges példaanyaggal illusztráljuk. Ezek a példák segítenek a megértésben, bemutatják az alkalmazás módját és számos esetben rávilágítanak a tételeinkben megfogalmazott feltételek fontosságára. Ezért az anyag elsajátításában a példák részletes áttanulmányozása kiemelkedően fontos otthoni feladat.

Minden egyes fejezet pontosan egy tanulmányi hét tanulnivalóit tartalmazza. Ennek megfelelően mindhárom félév tananyaga, 12 szorgalmi hetet feltételezve, 12 fejezetre oszlik. Mindegyik fejezet végén részletes útmutatót adunk az otthoni tanuláshoz, és a feladatokon keresztüli gyakorláshoz. Az útmutatókban szereplő feldolgozandó tankönyvi utalásokat a következóképpen kell értelmezni.

Tankönyv-1: K. Sydsaeter, P. Hammond: Matematika közgazdászoknak, Aula Kiadó, Budapest, 2005.

Feladatgyứjtemény-1: Ernyes Éva, Mala József, Orosz Ágota, Racsmány Anna, Szakál Szilvia: Matematikai alapok feladatgyújtemény, Aula Kiadó, Budapest, 2007.

Tankönyv-2: Denkinger Géza: Valószínűségszámítás, Tankönyvkiadó, Budapest, 1977.

Feladatgyứjtemény-2: Denkinger Géza: Valószínúségszámítási gyakorlatok, Tankönyvkiadó, Budapest, 1977. 
Köszönettel tartozom a könyv lektorának Komlósi Sándornak, valamint Puskás Csaba, Ernyes Éva, és Fleiner Balázs tanszéki kollégáimnak, akik megjegyzéseikkel, javaslataikkal segítettek érthetôbbé tenni a tananyagot. A tananyag oktatásában szerzett tapasztalat, és a visszajelzések függvényében az internetes file folyamatosan frissül.

Budapest, 2018. június.

Tallos Péter 
I. rész

Első félév:

Differenciál és

integrálszámítás 

1. SOROZATOK 



\subsection{A határérték definiciója}

A természetes számok $\mathbb{N}$ halmazán értelmezett

$$
a: \mathbb{N} \rightarrow \mathbb{R}
$$

függvényt (végtelen) sorozatnak nevezzük. A sorozat $n$-ik elemére az $a_{n}$ jelölést használjuk. Ha ez nem okoz félreértést, a sorozat jelölésére röviden az $a_{n}$ szimbólumot használjuk.

1.1 Definíció. Azt mondjuk, hogy az $a_{n}$ sorozat konvergens, és az A számhoz tart, jelölésben $a_{n} \rightarrow A$, vagy

$$
\lim _{n \rightarrow \infty} a_{n}=A,
$$

ha bármely $\varepsilon$ pozitív számhoz van olyan $N$ index, hogy minden $n \geq N$ indexre

$$
\left|a_{n}-A\right|<\varepsilon .
$$

Ha ilyen $A$ valós szám nincs, akkor azt mondjuk, hogy a sorozat divergens.

Konvergens sorozat esetében azt is mondjuk, hogy az $A$ szám az $a_{n}$ sorozat határértéke.

1.2 Példa. Tekintsük az $a_{n}=1 / n$ sorozatot. Ekkor tetszőleges $\varepsilon>0$ mellett legyen $N$ az $1 / \varepsilon$ számnál nagyobb egész szám. Világos, hogy minden $n \geq N$ esetén

$$
\frac{1}{n}<\varepsilon
$$

ezért az 1.1Definíció értelmében

$$
\lim _{n \rightarrow \infty} \frac{1}{n}=0 .
$$

1.3 Példa. Hasonló módon más sorozatok határértékét is meghatározhatjuk. Tekintsük például az

$$
a_{n}=\frac{2 n^{2}+5}{n^{2}-6 n+8}
$$

sorozatot. Ha a számlálót és a nevezőt is $n^{2}$-tel osztjuk, akkor a sorozat $n$-ik eleme

$$
a_{n}=\frac{2+5 / n^{2}}{1-6 / n+8 / n^{2}}
$$

alakba írható, ahol a számláló határértéke 2, a nevezőé pedig 1, így

$$
\lim _{n \rightarrow \infty} a_{n}=2 \text {. }
$$


Minden irracionális szám előáll racionális számok sorozatának határértékeként. Például az $a_{1}=1.4, a_{2}=1.41, a_{3}=1.414, a_{4}=1.4142 \ldots$ sorozat esetén

$$
\lim _{n \rightarrow \infty} a_{n}=\sqrt{2}
$$

Valóban, a 1.1 Definíció értelmében, ha $\varepsilon=10^{-N}$, akkor az $n \geq N$ indexekre $\mid a_{n}-$ $\sqrt{2} \mid<\varepsilon$.

Tipikus példa olyan sorozatra, amelynek nincs határértéke:

$$
a_{n}=(-1)^{n}
$$

hiszen itt a páros indexú elemek értéke 1, a páratlan indexúeké pedig -1.

1.4 Tétel. Legyenek $a_{n}$ és $b_{n}$ olyan sorozatok, amelyekre $\lim a_{n}=A$ és $\lim b_{n}=B$. Ekkor $\lim \left(a_{n}+b_{n}\right)=A+B$ és $\lim \left(a_{n} b_{n}\right)=A B$. Ha még egyik $b_{n}$ sem nulla és $B \neq 0$, akkor $\lim \left(a_{n} / b_{n}\right)=A / B$.

\subsection{Végtelenbe tartó sorozatok}

Vannak olyan sorozatok is, amelyeket nem nevezünk konvergensnek, de létezik határértékük. Vizsgáljuk meg például az

$$
a_{n}=2 n+5
$$

(számtani) sorozatot. Ez a sorozat bármely előre megadott $K$ valós számnál nagyobb értékeket vesz föl egy indextől kezdve. Ilyenkor azt mondjuk, hogy a sorozat határértéke $+\infty$.

1.5 Definíció. Azt mondjuk, hogy az $a_{n}$ sorozat határértéke $+\infty$, jelölésben

$$
\lim _{n \rightarrow \infty} a_{n}=+\infty
$$

ha bármely elôre megadott $K$ valós számhoz található olyan $N$ index, hogy minden $n \geq N$ mellett $a_{n}>K$.

Teljesen hasonló módon értelmezhetjük azt, hogy egy sorozat a $-\infty$-hez tart, azaz $\lim _{n \rightarrow \infty} a_{n}=-\infty$. 


\subsection{A rendőr-elv}

Sorozatok határértéke gyakran meghatározható más, ismert sorozatok határértéke segítségével. Ezt fogalmazza meg a rendőr-elv.

1.6 Tétel. Legyenek $a_{n}, b_{n}$ és $c_{n}$ olyan sorozatok, amelyekre minden $n$ indexre

$$
a_{n} \leq b_{n} \leq c_{n}
$$

továbbá az $a_{n}$ és $c_{n}$ sorozatoknak létezik határértéke és

$$
\lim _{n \rightarrow \infty} a_{n}=\lim _{n \rightarrow \infty} c_{n}=A .
$$

Akkor a $b_{n}$ sorozatnak is létezik határértéke éspedig $\lim _{n \rightarrow \infty} b_{n}=A$.

1.7 Példa. Legyen $a>1$ valós szám, és tekintsük a $b_{n}=\sqrt[n]{a}$ sorozatot. Mivel $a>1$, azért a sorozat elemei

$$
\sqrt[n]{a}=1+h_{n}
$$

alakban írhatók fel, ahol $h_{n}>0$. Innen a binomiális tétel szerint

$$
a=\left(1+h_{n}\right)^{n}>1+n h_{n} .
$$

Az egyenlőtlenség átrendezésével

$$
0<h_{n}<\frac{a-1}{n}
$$

Mivel a jobb oldali kifejezés nullához tart, a rendőr-elv szerint $h_{n} \rightarrow 0$, azaz $\sqrt[n]{a} \rightarrow 1$.

Nyilván hasonló megállapítást tehetünk, ha $0<a \leq 1$, hiszen akkor a sorozat elemeinek reciprokaira térhetünk át.

\subsection{Korlátosság és monotonitás}

Egy végtelenbe tartó sorozat elemei természetesen nem maradnak két fixen választott valós szám között. Bevezetjük az alábbi definíciót.

1.8 Definíció. Az $a_{n}$ sorozatot felülről korlátosnak nevezzük, ha van olyan $K$ valós szám, hogy $a_{n} \leq K$ minden $n$ indexre. Hasonlóan értelmezzük az alulról korlátos sorozatokat. Egy sorozatot korlátosnak nevezünk, ha felülről és alulról is korlátos. 
1.9 Példa. Döntsük el például, hogy az

$$
a_{n}=\frac{2 n}{\sqrt{4 n^{2}+5}+8}
$$

sorozat korlátos-e? Ha a számlálót és a nevezőt is $2 n$-nel osztjuk, akkor

$$
a_{n}=\frac{1}{\sqrt{1+5 / 4 n^{2}}+8 / 2 n}
$$

aminek alapján $0 \leq a_{n} \leq 1$, ezért a sorozat alulról és felülrôl is korlátos. Az is világos, hogy e sorozat legkisebb felső korlátja 1, míg egy (de nem a legnagyobb) alsó korlátja 0 .

Kitüntetett szerepe van a monoton sorozatoknak.

1.10 Definíció. Azt mondjuk, hogy az $a_{n}$ sorozat monoton növő, ha minden $n$ indexre $a_{n} \leq a_{n+1}$. Hasonlóan értelmezzük a monoton fogyó sorozatokat.

1.11 Példa. Tekintsük például az

$$
a_{n}=\frac{2 n-1}{n+2}
$$

sorozatot. Egyszerű átalakítással látható, hogy

$$
a_{n}=\frac{2 n+4-5}{n+2}=2-\frac{5}{n+2}
$$

azaz a 2-ből levont tört értéke csökken, ha $n$ növekszik, ezért a sorozat monoton növő, tehát $a_{n} \leq a_{n+1}$ minden $n$ indexre. Az is világos, hogy ez a sorozat felülrôl korlátos, és a legkisebb felsô korlátja 2, valamint

$$
\lim _{n \rightarrow \infty} a_{n}=2 .
$$

Az alábbi tételünk azt mondja ki, hogy ez a tulajdonság monoton és korlátos sorozatokra tipikus jelenség.

1.12 Tétel. Egy monoton növó és felülról korlátos sorozat konvergens.

A tételt nem igazoljuk, csak megjegyezzük, hogy a valós számok azon tulajdonságán múlik, hogy a felső korlátok között mindig van legkisebb. Ezt a sorozat felsô határának nevezzük. Nyilván analóg állítást fogalmazhatunk meg monoton fogyó és alulról korlátos sorozatokra. 


\subsection{Az Euler-féle $e$ szám}

Nevezetes, és gyakran előforduló sorozat az

$$
a_{n}=\left(1+\frac{1}{n}\right)^{n}
$$

Megmutatható, hogy ez a sorozat monoton növő és felülről korlátos, így konvergens is. Ehhez felhasználjuk a számtani és mértani közepek közötti egyenlőtlenséget. Nevezetesen, ha $x_{1}, \ldots, x_{n}$ pozitív számok, akkor

$$
x_{1} \ldots x_{n} \leq\left(\frac{x_{1}+\ldots+x_{n}}{n}\right)^{n}
$$

bármely $n$ természetes számra, és egyenlőség akkor és csak akkor áll fenn, ha $x_{1}=\ldots=$ $x_{n}$, azaz mindegyik szám egyenlő.

1.13 Állítás. Az 1.1 alatti $a_{n}$ sorozat szigorúan monoton növó és felülról korlátos.

Bizonyítás. Legyen adott egy $n$ természetes szám. Először tekintsük az

$$
x_{1}=1+\frac{1}{n}, \ldots, x_{n}=1+\frac{1}{n}, x_{n+1}=1
$$

$n+1$ darab pozitív számot, amelyek nem mind egyenlőek. Ezekre a számtani-mértani egyenlőtlenség az

$$
\left(1+\frac{1}{n}\right)^{n}<\left(\frac{n+1+1}{n+1}\right)^{n+1}=\left(1+\frac{1}{n+1}\right)^{n+1}
$$

alakot ölti, ahonnan látszik, hogy a sorozat szigorúan monoton növő.

Másodszor tekintsük az

$$
x_{1}=1+\frac{1}{n}, \ldots, x_{n}=1+\frac{1}{n}, x_{n+1}=\frac{1}{2}, x_{n+2}=\frac{1}{2}
$$

$n+2$ darab különböző pozitív számot. Ezekre a számtani-mértani egyenlőtlenség

$$
\frac{1}{4} \cdot\left(1+\frac{1}{n}\right)^{n}<\left(\frac{n+1+1}{n+2}\right)^{n+2}=1
$$

alakban írható fel. Innen adódik, hogy $a_{n}<4$, azaz a sorozat felülrôl korlátos, és ezért konvergens is. 
E sorozat határértékére az $e$ jelölést használjuk. Pontosabb számítás azt mutatja, hogy $e$ irracionális, és

$$
e=2.7182 \ldots
$$

1.14 Állítás. Legyen $\alpha$ tetszóleges valós szám. Akkor

$$
\lim _{n \rightarrow \infty}\left(1+\frac{\alpha}{n}\right)^{n}=e^{\alpha}
$$

1.15 Példa. Tekintsük például az

$$
a_{n}=\left(\frac{2 n+1}{2 n+3}\right)^{n}
$$

sorozatot. Ekkor

$$
a_{n}=\left(\frac{2 n+1}{2 n+3}\right)^{n}=\frac{\left(1+\frac{1 / 2}{n}\right)^{n}}{\left(1+\frac{3 / 2}{n}\right)^{n}} \rightarrow \frac{e^{1 / 2}}{e^{3 / 2}}
$$

és így $\lim _{n \rightarrow \infty} a_{n}=e^{-1}$.

\section{Otthoni tanuláshoz}

1. A Feladatgyưjjtemény-1 I/1 szakasza kidolgozott példáinak feldolgozása.

2. Házi feladatok: az I/1 szakasz 1.1.5, 1.1.6, 1.1.8, 1.2.5, 1.2.6, 1.2.8, 1.3.6, 1.3.9, 1.6.2, 1.8.6, 1.8.9 feladatai.

3. Tankönyv-1 1 . fejezet és 6.4 szakasz. 


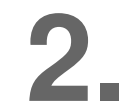

VÉGTELEN SOROK 



\subsection{Végtelen sorok konvergenciája}

Tekintsünk egy végtelen valós $a_{k}$ sorozatot és képezzük a formális

$$
\sum_{k=1}^{\infty} a_{k}
$$

összeget. Ezt a szimbólumot végtelen sornak nevezzük.

Természetesen meg kell mondanunk, hogy mit értünk egy ilyen kifejezésen, hiszen végtelen sok tagú összeget eddig nem értelmeztünk.

Legyen $n$ tetszőleges természetes szám és vezessük be a 2.1 sor $n$-ik részletösszegét az alábbi módon:

$$
S_{n}=\sum_{k=1}^{n} a_{k}
$$

Ilyen módon egy $S_{n}$ valós sorozatot képeztünk.

2.1 Definíció. Azt mondjuk, hogy a 2.1 végtelen sor konvergens, és az összege az $S$ valós szám, jelölésben

$$
S=\sum_{k=1}^{\infty} a_{k}
$$

ha az $S_{n}$ számsorozat konvergens és határértéke $S$. Ellenkező esetben a sort divergensnek nevezzük.

Egy végtelen sor tehát divergens, ha az $S_{n}$ sorozatnak nincs határértéke, de akkor is, ha ez a határérték létezik, de végtelen. Például ha $a_{k}=(-1)^{k}$ minden $k$ esetén, akkor

$$
S_{n}=\sum_{k=1}^{n}(-1)^{k}=0 \text { ha } n \text { páros és } S_{n}=\sum_{k=1}^{n}(-1)^{k}=-1 \text { ha } n \text { páratlan }
$$

és ez az $S_{n}$ sorozat nyilvánvalóan divergens.

\subsection{A geometriai sor}

2.2 Példa. (A geometriai sor) Legyen $r$ valós szám, és tekintsük az $r$ hányadosú geometriai sort:

$$
\sum_{k=0}^{\infty} r^{k}
$$

Ennek a sornak az $n$-ik részletösszege:

$$
S_{n}=\sum_{k=0}^{n} r^{k}=\frac{1-r^{n+1}}{1-r}
$$


Itt a sorozatokról tanultak alapján $r^{n} \rightarrow 0$ ha $|r|<1$, minden más esetben a sorozat divergens. Tehát a geometriai sor akkor és csak akkor konvergens, ha $|r|<1$, és ekkor

$$
S=\sum_{k=0}^{\infty} r^{k}=\frac{1}{1-r}
$$

hiszen $|r|<1$ esetén $r^{n} \rightarrow 0$.

\subsection{Konvergencia a részletösszegek alapján}

2.3 Példa. További példaként vizsgáljuk meg a

$$
\sum_{k=2}^{\infty} \frac{1}{k(k-1)}
$$

végtelen sort. Mivel

$$
\frac{1}{k(k-1)}=\frac{1}{k-1}-\frac{1}{k}
$$

azért a sor $n$-ik részletösszege az alábbi módon írható:

$$
S_{n}=(1-1 / 2)+(1 / 2-1 / 3)+\ldots+(1 /(n-1)-1 / n)=1-1 / n
$$

ahol az egymást követô zárójelekben a negatív és pozitív tagok kiejtik egymást. Ennek a sorozatnak a határértéke 1 , tehát a sor konvergens és az összege $S=1$.

\subsection{Feltételek konvergenciára}

2.4 Tétel. (A konvergencia szükséges feltétele) Tegyük fel, hogy a

$$
\sum_{k=1}^{\infty} a_{k}
$$

sor konvergens. Akkor $\lim _{k \rightarrow \infty} a_{k} \rightarrow 0$.

2.5 Példa. Tételünk csak szükséges feltételt fogalmaz, de nem elégséges. Például megmutatható, hogy a

$$
\sum_{k=1}^{\infty} \frac{1}{k}
$$

sorra a szükséges feltétel teljesül, de a sor divergens. Ezt a sort harmonikus sornak nevezzük. 
Valóban, legyen $n$ adott természetes szám, és tekintsük a harmonikus sor $2^{n}$-ik részletösszegét. Csoportosítsuk a tagokat a következő módon:

$$
S_{2^{n}}=1+\frac{1}{2}+\left(\frac{1}{3}+\frac{1}{4}\right)+\left(\frac{1}{5}+\ldots+\frac{1}{8}\right)+\ldots+\left(\frac{1}{2^{n-1}+1}+\ldots+\frac{1}{2^{n}}\right),
$$

ahol mindegyik zárolejeles kifejezésben a következő 2 hatványig megyünk el. Könnyen látható, hogy mindegyik zárójelen belül a tagok összege több, mint 1/2, ezért

$$
S_{2^{n}}>1+\frac{1}{2} n .
$$

Innen adódik, hogy a részletösszegek sorozata nem korlátos, ezért a harmonikus sor divergens.

2.6 Tétel. (A konvergencia elégséges feltétele) Tegyük fel, hogy minden $k$ indexre $a_{k} \geq 0$ és $a$

$$
\sum_{k=1}^{\infty} a_{k}
$$

sor konvergens. Ha minden $k$ indexre $0 \leq b_{k} \leq a_{k}$, akkor a

$$
\sum_{k=1}^{\infty} b_{k}
$$

sor is konvergens.

Valóban, a feltételeink szerint az $S_{n}=\sum_{k=1}^{n} b_{k}$ részletösszegek sorozata egyrészt monoton növő, másrészt felülről korlátos, tehát konvergens is.

Hasonló módon nyerhetünk elégséges feltételt divergenciára is: egy nemnegatív tagú divergens sor tagjainál nagyobb tagokból álló sor nyilvánvalóan szintén divergens!

2.7 Példa. Példaként tekintsük a $\sum_{k=1}^{\infty} 1 / k^{2}$ sort. Mivel minden $k>1$ indexre

$$
\frac{1}{k^{2}}<\frac{1}{k(k-1)}
$$

azért az $n$-ik részletösszegre az adódik, hogy

$$
S_{n}=\sum_{k=1}^{n} \frac{1}{k^{2}}<1+\sum_{k=2}^{n} \frac{1}{k(k-1)}
$$

Tehát az elégséges feltételünk szerint a fenti sor konvergens és az összege $S<2$.

Általában megmutatható, hogy a $\sum_{k=1}^{\infty} 1 / k^{\alpha}$ sor divergens, ha $\alpha \leq 1$, és konvergens, ha $\alpha>1$ (lásd a 9. fejezetben). 


\subsection{Abszolút konvergencia}

Ebben a szakaszban olyan végtelen sorokat vizsgálunk, amelyekben pozitív és negatív tagok is előfordulhatnak. Tekintsük ezért a

$$
\sum_{k=1}^{\infty} a_{k}
$$

végtelen sort, ahol az $a_{k}$ tagok nem feltétlenül mind nemnegatívak.

2.8 Definíció. Azt mondjuk, hogy a 2.3 sor abszolút konvergens, ha a

$$
\sum_{k=1}^{\infty}\left|a_{k}\right|
$$

sor konvergens.

2.9 Tétel. Ha egy sor abszolút konvergens, akkor konvergens is.

A bizonyítás részleteibe nem megyünk. Indoklásként azonban megjegyezzük a következőket. Jelentse $S_{n}$ az első $n$ tag abszolút értékeinek összegét, ez a feltételünk szerint konvergens, azaz

$$
\lim \sum_{k=1}^{n}\left|a_{k}\right|=\lim S_{n}=S .
$$

Jelentse továbbá $R_{n}$ illetve $T_{n}$ a $\sum_{k=1}^{\infty} a_{k}$ sor első $n$ tagjából a negatív, illetve a nemnegatív tagok összegét. Ekkor $R_{n}$ monoton fogyó, illetve $T_{n}$ monoton növő, és mindkét sorozat korlátos, hiszen

$$
R_{n} \geq-S \text { illetve } T \leq S .
$$

Ezért mindkét sorozat konvergens, jelölésben $\lim R_{n}=R$, illetve $\lim T_{n}=T$. Tehát a sor $n$-ik részletösszege

$$
\lim \sum_{k=1}^{n} a_{k}=\lim \left(T_{n}+R_{n}\right)=T+R,
$$

azaz a sor valóban konvergens.

Az alábbi példában megmutatjuk, hogy a fenti tételünk állítása nem fordítható meg.

2.10 Példa. Tekintsük az alábbi váltakozó előjelû sort:

$$
\sum_{k=1}^{\infty} \frac{(-1)^{k-1}}{k}
$$

Világos, hogy ez a sor nem abszolút konvergens, hiszen a tagok abszolút értékeiből álló sor éppen a harmonikus sor, amely divergens. 
Megmutatjuk azonban, hogy a fenti sor konvergens. Valóban, a páros indexú részletösszegek sorozatára az adódik, hogy

$$
\begin{aligned}
S_{2 n} & =\left(1-\frac{1}{2}\right)+\left(\frac{1}{3}-\frac{1}{4}\right)+\ldots+\left(\frac{1}{2 n-1}-\frac{1}{2 n}\right)= \\
& =\frac{1}{2}+\frac{1}{12}+\ldots+\frac{1}{2 n(2 n-1)} .
\end{aligned}
$$

A 2.3 Példa alapján ez a sorozat monoton növő, és felülről korlátos, hiszen $S_{2 n}<2$. Tehát konvergens is, jelölje a határértéket

$$
\lim S_{2 n}=S
$$

Másrészt a páratlan indexű részletösszegekre

$$
S_{2 n-1}=S_{2 n}+\frac{1}{2 n}
$$

ezért $\lim S_{2 n-1}=S$, tehát $\lim S_{n}=S$. Ez azt jelenti, hogy a sor konvergens.

\subsection{Hányados-kritérium}

Az alábbiakban egy elégséges feltételt feltételt fogalmazunk meg sorok konvergenciájára, illetve divergenciájára. Képezzük a

$$
\sum_{k=1}^{\infty} a_{k}
$$

sor szomszédos tagjainak hányadosait, és tegyük fel, hogy létezik a

$$
\lim _{k \rightarrow \infty}\left|\frac{a_{k+1}}{a_{k}}\right|=\alpha
$$

határérték.

\subsection{Tétel. (Hányados-kritérium)}

- Ha $\alpha<1$, akkor a sor abszolút konvergens.

- Ha $\alpha>1$, akkor a sor divergens.

- ha $\alpha=1$, akkor mindkét eset lehetséges. 
Bizonyítás. Ha $\alpha<1$, akkor válasszunk egy $\beta$ számot, amelyre $\alpha<\beta<1$. Ekkor valamely $N$ indextôl kezdve

$$
\left|\frac{a_{k+1}}{a_{k}}\right|<\beta
$$

minden $k \geq N$ indexre. Innen lépesenként visszafelé haladva azt kapjuk, hogy

$$
\left|a_{k+1}\right|<\beta\left|a_{k}\right|<\beta^{2}\left|a_{k-1}\right|<\ldots<\beta^{k-N+1}\left|a_{N}\right|
$$

Tehát az $n+1$-ik részletösszegre

$$
S_{n+1}=\sum_{k=0}^{n}\left|a_{k+1}\right|<\sum_{k=0}^{N-1}\left|a_{k+1}\right|+\left|a_{N}\right| \cdot \sum_{k=N}^{n} \beta^{k-N+1}
$$

ahol az utóbbi szumma $0<\beta<1$ miatt egy konvergens geometriai sor részletösszege, tehát korlátos, ha $n \rightarrow \infty$. Innen adódik az állítás.

Ha $\alpha>1$, akkor a bizonyítás hasonlóan végezhető el, csak $1<\beta<\alpha$ választással egy divergens geometriai sorra vezetjük vissza.

2.12 Példa. Ebben a példában megmutatjuk, hogy $\alpha=1$ esetén a sor konvergenciájáról semmit sem mondhatunk a Hányados-kritérium alapján.

Valóban, ha a divergens harmonikus sort tekintjük, akkor $a_{k}=1 / k$ miatt

$$
\frac{a_{k+1}}{a_{k}}=\frac{k}{k+1} \rightarrow 1 \quad \text { ha } k \rightarrow \infty .
$$

Ha viszont azt a konvergens sort tekintjük, ahol $a_{k}=1 / k^{2}$, akkor

$$
\frac{a_{k+1}}{a_{k}}=\left(\frac{k}{k+1}\right)^{2} \rightarrow 1 \quad \text { ha } k \rightarrow \infty,
$$

azaz valóban mindkét eset előfordulhat.

2.13 Példa. Vizsgáljuk meg, hogy konvergens-e a

$$
\sum_{k=1}^{\infty} \frac{k^{2} \cdot 2^{k}}{k !}
$$

sor. Használjuk a Hányados-kritériumot:

$$
\frac{a_{k+1}}{a_{k}}=\frac{(k+1)^{2} 2^{k+1}}{(k+1) !} \cdot \frac{k !}{k^{2} 2^{k}}=2\left(\frac{k+1}{k}\right)^{2} \cdot \frac{1}{k+1} \rightarrow 0
$$

Tehát $\alpha=0<1$, azaz a sor konvergens. 


\section{Otthoni tanuláshoz}

1. A Feladatgyújtemény-1 I/2 szakasz kidolgozott példáinak feldolgozása.

2. Házi feladatok: az I/2 szakasz 2.1.7, 2.1.8, 2.1.9, 2.1.10, 2.1.11, 2.2.3, 2.2.4, 2.2.8, 2.2.9, 2.3.10, 2.3.11, 2.3.12, 2.3.15 feladatai.

3. Tankönyv-1 6.5 szakasza. 



\section{FÜGGVÉNYEK HATÁRÉRTÉKE ÉS FOLYTONOSSÁG}





\subsection{Függvények határértéke}

Az alábbiakban $f: \mathbb{R} \rightarrow \mathbb{R}$ függvények határértékével foglalkozunk. Legyen $x_{0}$ olyan pont (lehet $\pm \infty$ is), amelyhez van olyan $x_{n}$ sorozat az $f$ értelmezési tartományából, hogy $x_{n} \neq x_{0}$ és $x_{n} \rightarrow x_{0}$.

3.1 Definíció. Azt mondjuk, hogy $f$ határértéke az $x_{0}$ pontban $A$ (ez lehet $\pm \infty$ is), jelölésben

$$
\lim _{x \rightarrow x_{0}} f(x)=A
$$

ha az értelmezési tartományból vett bármely $x_{n} \rightarrow x_{0}$ sorozatra amelyre $x_{n} \neq x_{0}$, $f\left(x_{n}\right) \rightarrow A$.

3.2 Példa. Határozzuk meg a

$$
\lim _{x \rightarrow 2} \frac{x^{2}-4}{x-2}
$$

határértéket! Ez a függvény az $x=2$ helyen nincs értelmezve, de minden $x \neq 2$ helyen $x+2$-vel egyenlő. Ezért könnyen látható, hogy

$$
\lim _{x \rightarrow 2} \frac{x^{2}-4}{x-2}=4
$$

3.3 Példa. Tekintsük az $f(x)=1 / x$ függvényt. Ez a függvény az $x=0$ helyen nincs értelmezve. Másrészt az értelmezési tartományból választott bármely $x_{n}>0, x_{n} \rightarrow 0$ sorozatra $f\left(x_{n}\right) \rightarrow+\infty$, míg ugyanezen sorozat negatívjaira $f\left(-x_{n}\right) \rightarrow-\infty$. Tehát ennek a függvénynek az $x=0$ helyen nincs határértéke, azaz

$$
\lim _{x \rightarrow 0} \frac{1}{x}
$$

nem létezik.

3.4 Példa. Tekintsük a következô határértéket:

$$
\lim _{x \rightarrow+\infty} \frac{2 x^{4}-5 x^{3}+x-8}{8 x^{3}-x^{2}+12}
$$

Ha a számlálóból és a nevezőből is $x^{3}$-t kiemelünk, akkor a

$$
\frac{2 x-5+1 / x^{2}-8 / x^{3}}{8-1 / x+12 / x^{3}}
$$

kifejezéshez jutunk. Ekkor bármely $x_{n} \rightarrow+\infty$ sorozat esetén a számláló határértéke $+\infty$, míg a nevező határértéke 8 , így a tört $+\infty$-hez tart. 
Hasonlóan látható, hogy e tört határértéke $-\infty$, ha $x \rightarrow-\infty$.

3.5 Példa. Lássuk be, hogy

$$
\lim _{x \rightarrow+\infty}\left(\sqrt{1+x^{2}}-x\right)=0 .
$$

Valóban,

$$
\sqrt{1+x^{2}}-x=\frac{1}{\sqrt{1+x^{2}}+x}
$$

és a jobb oldali kifejezés 0 -hoz tart, ha $x \rightarrow+\infty$.

A 1.4 Tétel alapján fogalmazhatjuk meg a következő állítást.

3.6 Tétel. Ha az $f$ és $g$ függvényekre

$$
\lim _{x \rightarrow x_{0}} f(x)=A \quad \text { és } \quad \lim _{x \rightarrow x_{0}} g(x)=B,
$$

akkor

$$
\lim _{x \rightarrow x_{0}}(f(x)+g(x))=A+B \quad \text { és } \quad \lim _{x \rightarrow x_{0}} f(x) g(x)=A B .
$$

Ha még g nem nulla az $x_{0}$ egy környezetében, és $B \neq 0$, akkor

$$
\lim _{x \rightarrow x_{0}} \frac{f(x)}{g(x)}=\frac{A}{B} .
$$

\subsection{A rendőr-elv}

A sorozatokhoz hasonlóan a függvények határértékére is érvényes a rendőr-elv.

3.7 Tétel. Legyenek $f, g$ és h olyan függvények, amelyekre minden x mellett

$$
f(x) \leq g(x) \leq h(x),
$$

továbbá $\lim _{x \rightarrow x_{0}} f(x)=\lim _{x \rightarrow x_{0}} h(x)=$ A. Akkor a g függvénynek is létezik határértéke az $x_{0}$ helyen, és

$$
\lim _{x \rightarrow x_{0}} g(x)=A
$$


3.8 Példa. Határozzuk meg a

$$
\lim _{x \rightarrow 0} \frac{\sin x}{x}
$$

határértéket! Ez a függvény páros, így elég pozitív $x$-eket vizsgálni. Geometriai interpretáció mutatja, hogy minden $0<x<\pi / 2$ pontban

$$
\sin x<x<\tan x
$$

azaz a $\sin x$ kifejezéssel osztva és reciprokra térve

$$
\cos x<\frac{\sin x}{x}<1 .
$$

Tehát a rendőr-elv alkalmazásával azt kapjuk, hogy

$$
\lim _{x \rightarrow 0} \frac{\sin x}{x}=1 \text {. }
$$

\subsection{Egyoldali határérték}

3.9 Definíció. Azt mondjuk, hogy az $f$ függvénynek az $x_{0}$ helyen létezik jobb oldali határértéke, és ez $A$, jelölésben

$$
\lim _{x \rightarrow x_{0}+} f(x)=A
$$

ha az értelmezési tartományból választott bármely $x_{n} \rightarrow x_{0}, x_{n}>x_{0}$ sorozatra $f\left(x_{n}\right) \rightarrow$ $A$. Analóg módon értelmezzük a bal oldali határértéket is.

3.10 Példa. Vizsgáljuk meg az alábbi függvényt:

$$
f(x)=\frac{2 x+1}{x-2}
$$

Nem hehéz belátni, hogy ha $x_{n}$ jobbról tart 2-höz, akkor $f\left(x_{n}\right) \rightarrow+\infty$, míg ha $x_{n}$ balról tart 2-höz, akkor $f\left(x_{n}\right) \rightarrow-\infty$. Ezért

$$
\lim _{x \rightarrow 2-} f(x)=-\infty \text { és } \lim _{x \rightarrow 2+} f(x)=+\infty .
$$




\subsection{Folytonosság}

Tekintsünk egy intervallumon értelmezett $f$ függvényt.

3.11 Definíció. Azt mondjuk, hogy az $f$ függvény az értelmezési tartomány valamely $x_{0}$ pontjában folytonos, ha

$$
\lim _{x \rightarrow x_{0}} f(x)=f\left(x_{0}\right) .
$$

Ha $f$ az értelmezési tartomány valamely $x_{0}$ pontjában nem folytonos, akkor azt mondjuk, hogy ott szakadása van.

FIGYELEM! Folytonosságról csak az értelmezési tartomány pontjaiban beszélhetünk. Például az $f(x)=1 / x$ függvény az értelmezési tartomány (azaz $x \neq 0$ ) minden pontjában folytonos. Az $x_{0}=0$ pont nincs az értelmezési tartományban, így ott nem is beszélhetünk szakadásról.

Másrészt azonban nem is definiálhatjuk az $f$ függvényt az $x_{0}=0$ pontban úgy, hogy ott folytonos legyen, hiszen ott a függvénynek nincs határértéke.

Általában elmondható, hogy a folytonos függvényekből kompozícióval, illetve az alapmúveletekkel előállított függvények folytonosak, kivéve, ha egy hányados nevezője nulla.

3.12 Példa. Tekintsük például az alábbi függvényt:

$$
f(x)= \begin{cases}\frac{1-\cos x}{x^{2}} & \text { ha } x \neq 0 \\ \frac{1}{2} & \text { ha } x=0\end{cases}
$$

Világos, hogy ez a függvény az $x \neq 0$ helyeken folytonos, másrészt

$$
\frac{1-\cos x}{x^{2}}=\frac{1-\cos ^{2} x}{(1+\cos x) x^{2}}=\left(\frac{\sin x}{x}\right)^{2} \cdot \frac{1}{1+\cos x}
$$

amiből látható, hogy a függvény határértéke a 0 helyen $1 / 2$. Tehát ez a függvény az egész számegyenesen folytonos.

\subsection{Folytonos függvények tulajdonságai}

Egy folytonos függvényt úgy képzelünk el, hogy a grafikonja folyamatos vonallal lerajzolható. Ezt fogalmazza meg Bolzano tétele.

3.13 Tétel. (Bolzano-tétel) Legyen $f$ folytonos függvény az $[a, b]$ intervallumon, és tegyük fel, hogy $f(a)$ és $f(b)$ ellenkezó elójelüek. Akkor van olyan $a<c<b$ hely, amelyre $f(c)=0$. 
A tételt nem bizonyítjuk, de egy rövid indoklást megmutatunk. Felezzük meg az $[a, b]$ intervallumot, és válasszuk azt a felét, amelynek végpontjaiban $f$ különböző előjelú (ha nulla lenne, akkor kész a bizonyítás). A kiválasztott részintervallumot újra megfelezzük, és újra azt a felét választjuk, amelynek végpontjaiban $f$ ellenkező előjelú, stb...

Az eljárást folytatva egymásba skatulyázott zárt intervallumok sorozatához jutunk, ahol az $n$-ik $\left[a_{n}, b_{n}\right]$ részintervallum hosszára azt kapjuk, hogy

$$
b_{n}-a_{n}=\frac{b-a}{2^{n}} .
$$

Úgy képzeljük, hogy ezen intervallumok metszete nem üres, és nyilván csak egyetlen pontot tartalmazhat. Jelölje $c \in[a, b]$ ezt a pontot, nevezetesen

$$
\bigcap_{n=1}^{\infty}\left[a_{n}, b_{n}\right]=\{c\} .
$$

Világos, hogy nem lehet $f(c)>0$, hiszen akkor a folytonosság miatt a $c$ egy kis környezetében is pozitív lenne, ami ellentmond a konstrukciónak. Hasonlóan nem lehet $f(c)<0$ sem. Tehát $f(c)=0$.

3.14 Példa. Vizsgáljuk meg, hogy vajon megoldható-e a

$$
2 x^{5}-18 x^{4}+3 x^{3}+20 x-13=0
$$

egyenlet? Világos, hogy a bal oldalon álló kifejezés egy folytonos $f$ függvényt definiál, amelyre

$$
\lim _{x \rightarrow+\infty} f(x)=+\infty \quad \text { és } \quad \lim _{x \rightarrow-\infty} f(x)=-\infty
$$

ezért $f$ elég nagy $x$ értékekre pozitív, míg elég kis $x$ értékekre negatív értéket vesz fel. Tehát Bolzano tétele szerint az egyenletnek van legalább egy valós gyöke.

A szélsőértékek és optimalizálási feladatok szempontjából alapvető jelentőségú a folytonos függvények következő tulajdonsága.

3.15 Tétel. (Weierstrass-tétel) Legyen $f$ folytonos függvény az $[a, b]$ intervallumon. Akkor $f$ ezen az intervallumon felveszi a maximumát és a minimumát.

Nem bizonyítunk, csak heurisztikus gondolatmenetet adunk pl. a maximum létezésére. Először gondoljuk meg, hogy $[a, b]$ intervallumon folytonos függvény felülrôl korlátos. Ezt indirekt módon láthatjuk be.

Másrészt úgy képzeljük (NEM NYILVÁNVALÓ!), hogy a felső korlátok között van legkissebb, jelölje ezt $M$. Ekkor bármely $n$ természetes számhoz van olyan $x_{n} \in[a, b]$, amelyre $f\left(x_{n}\right)>M-1 / n$. Ellenkezô esetben ugyanis $M-1 / n$ lenne a legkissebb felsô korlát. 
Ha most az $x_{n}$ sorozatnak valamely részsorozata a $c \in[a, b]$ számhoz tart, akkor a folytonosság miatt $f\left(x_{n}\right) \rightarrow f(c)$. Továbbá

$$
M-\frac{1}{n}<f\left(x_{n}\right) \leq M
$$

ezért a Rendôr-elv miatt csak $f(c)=M$ állhat fenn.

Hasonló gondolatmenet alkalmazható minimum esetére.

Például az

$$
f(x)= \begin{cases}x & \text { ha } 0 \leq x \leq 1 \\ 3-x & \text { ha } 1<x \leq 2\end{cases}
$$

függvény nem veszi fel a maximumát a $[0,2]$ intervallumon, de nem is folytonos az 1 helyen.

\section{Otthoni tanuláshoz}

1. A Feladatgyưjtemény-1 I/4 és I/5 szakaszok kidolgozott példáinak feldolgozása.

2. Házi feladatok: az I/4 szakasz 4.1.4, 4.1.5, 4.2.5, 4.3.6, 4.3.9, 4.4.6, 4.4.7, továbbá az I/5 szakasz 5.1.7, 5.1.8, 5.2.1 feladatai.

3. Tankönyv-1 2. és 3. fejezetek, 6.1, 6.2, 6.3, 6.6, 6.7, 7.1 és 7.2 szakaszok. 


\section{4.}

FÜGGVÉNYEK DERIVÁLTJA 



\subsection{A derivált fogalma}

Legyen $f$ valamely intervallumon értelmezett függvény, és tegyük fel, hogy $x_{0}$ az intervallum belső pontja.

4.1 Definíció. Azt mondjuk, hogy $f$ differenciálható az $x_{0}$ pontban, ha létezik és véges az alábbi határérték:

$$
\lim _{h \rightarrow 0} \frac{f\left(x_{0}+h\right)-f\left(x_{0}\right)}{h}
$$

Ezt a határértéket az $f$ deriváltjának nevezzük az $x_{0}$ pontban, jelölése $f^{\prime}\left(x_{0}\right)$. Az $f$ függvényt differenciálhatónak nevezzük egy intervallumban, ha annak minden belsô pontjában differenciálható.

A fenti hányadost az $f$ függvény különbségi hányadosának nevezzük az $x_{0}$ pontban.

4.2 Példa. Tekintsük az $f(x)=x^{2}$ függvényt. Az $x_{0}$ pontbeli különbségi hányados:

$$
\frac{f\left(x_{0}+h\right)-f\left(x_{0}\right)}{h}=\frac{\left(x_{0}+h\right)^{2}-x_{0}^{2}}{h}=2 x_{0}+h
$$

amelynek határértéke $2 x_{0}$, ha $h \rightarrow 0$. Következésképpen

$$
f^{\prime}\left(x_{0}\right)=2 x_{0}
$$

Teljesen hasonló módon látható, hogy $f(x)=x^{n}$ esetén, ahol $n$ természetes szám,

$$
f^{\prime}\left(x_{0}\right)=n x_{0}^{n-1}
$$

4.3 Állítás. Ha $f$ differenciálható az x pontban, akkor ott folytonos is.

Bizonyítás. Legyen $h_{n} \rightarrow 0$ tetszőleges sorozat, akkor a differenciálhatóság folytán

$$
\lim _{n \rightarrow \infty} \frac{f\left(x+h_{n}\right)-f(x)}{h_{n}}=f^{\prime}(x) .
$$

Ez csak úgy lehetséges, ha $\lim _{n \rightarrow \infty}\left(f\left(x+h_{n}\right)-f(x)\right)=0$, azaz $\lim _{n \rightarrow \infty} f\left(x+h_{n}\right)=$ $f(x)$. Ez éppen azt jelenti, hogy $f$ folytonos az $x$ pontban. 
FIGYELEM! Az állítás megfordítása általában nem igaz, amint azt a következő példa mutatja.

4.4 Példa. Tekintsük az $f(x)=|x|$ függvényt a számegyenesen, és vizsgáljuk meg az $x_{0}=0$ pontbeli különbségi hányadost. Világos, hogy

$$
\frac{f(h)-f(0)}{h}=\frac{|h|}{h}=\left\{\begin{array}{rr}
1 & \text { ha } h>0 \\
-1 & \text { ha } h<0
\end{array}\right.
$$

ezért a határérték $h \rightarrow 0$ esetén nem létezik, hiszen a jobb oldali határérték +1 , míg a bal oldali határérték -1 . Tehát az $f$ függvény a 0 pontban nem differenciálható.

Minden más pontban azonban igen, nevezetesen $f^{\prime}(x)=1$, ha $x>0$, és $f^{\prime}(x)=-1$, ha $x<0$.

\subsection{Görbék érintője}

A geometriai interpretáció azt mutatja, hogy az $f^{\prime}\left(x_{0}\right)$ derivált az $f$ függvény grafikonjához az $x_{0}$ pontban húzott érintő meredekségét jelenti.

Ennek alapján meghatározhatjuk egy differenciálható függvény grafikonjához az $x_{0}$ pontban húzható érintő egyenletét:

$$
y=f^{\prime}\left(x_{0}\right)\left(x-x_{0}\right)+f\left(x_{0}\right) .
$$

Például az $f(x)=x^{3}$ függvény grafikonjához az $x_{0}=1$ pontban húzható érintố egyenlete:

$$
y=3(x-1)+1
$$

4.5 Példa. Állítsuk elő az $f(x)=\sin x$ függvény grafikonjához az $x_{0}=0$ pontban húzott érintő egyenletét. Ekkor az érintő egyrészt átmegy az origón, másrészt a meredeksége:

$$
f^{\prime}(0)=\lim _{h \rightarrow 0} \frac{f(h)-f(0)}{h}=\lim _{h \rightarrow 0} \frac{\sin h}{h}=1 .
$$

Ezért az érintő egyenlete $y=x$, amely az origóban átmetszi a grafikont.

\subsection{Differenciálási szabályok}

Tekintsük az $f$ és $g$ függvényeket, amelyek egyaránt differenciálhatók az $x$ pontban. A határérték tulajdonságaiból adódnak az alábbi szabályok. 
Összeg és számszoros deriváltja Ha $\alpha$ és $\beta$ tetszőleges valós számok, akkor $\alpha f(x)+$ $\beta g(x)$ is differenciálható az $x$ pontban és

$$
(\alpha f(x)+\beta g(x))^{\prime}=\alpha f^{\prime}(x)+\beta g^{\prime}(x),
$$

Szorzat deriváltja $f(x) \cdot g(x)$ is differenciálható és

$$
(f(x) \cdot g(x))^{\prime}=f^{\prime}(x) \cdot g(x)+f(x) \cdot g^{\prime}(x),
$$

Hányados deriváltja ha $g(x) \neq 0$, akkor $f(x) / g(x)$ is differenciálható és

$$
\left(\frac{f(x)}{g(x)}\right)^{\prime}=\frac{f^{\prime}(x) g(x)-f(x) g^{\prime}(x)}{g(x)^{2}} .
$$

Példaként tekintsük a szorzat differenciálási szabályának igazolását.

$$
\begin{aligned}
& \frac{f(x+h) \cdot g(x+h)-f(x) \cdot g(x)}{h}= \\
& \frac{f(x+h) \cdot g(x+h)-f(x+h) \cdot g(x)}{h}+ \\
& \frac{f(x+h) \cdot g(x)-f(x) \cdot g(x)}{h}= \\
& f(x+h) \frac{g(x+h)-g(x)}{h}+g(x) \frac{f(x+h)-f(x)}{h}
\end{aligned}
$$

Itt az elsô tört határértéke $f(x) g^{\prime}(x)$ az $f$ folytonossága miatt, míg a második tört $f^{\prime}(x) g(x)$-hez tart, ha $h \rightarrow 0$. Innen adódik az állítás. A többi szabály igazolása hasonlóan történik.

4.6 Példa. Mutassuk meg, hogy az $f(x)=1 / x$ függvény grafikonjának bármely pontjában húzott érintô a koordináta-tengelyekkel azonos területû háromszöget zár be.

A szimmetria miatt nyilván elég $x_{0}>0$ koordinátájú pontokra szorítkozni. A hányados deriválási szabálya alapján

$$
f^{\prime}\left(x_{0}\right)=-\frac{1}{x_{0}^{2}}
$$

ezért az $x_{0}$ pontban húzható érintő egyenlete

$$
y=-\frac{1}{x_{0}^{2}}\left(x-x_{0}\right)+\frac{1}{x_{0}}
$$

Ennek az egyenesnek a tengelymetszetei: 


$$
x=0 \text { esetén az } y \text {-tengelyen } b=2 / x_{0}
$$

illetve

$$
y=0 \text { esetén az } x \text {-tengelyen } a=2 x_{0} .
$$

Tehát a közbezárt háromszög területe

$$
T=\frac{1}{2} a b=\frac{1}{2} \cdot 2 x_{0} \cdot \frac{2}{x_{0}}=2
$$

ami valóban független az $x_{0}$ pont választásától.

\subsection{Függvények kompozíciója}

Legyenek $f$ és $g$ egyaránt $\mathbb{R} \rightarrow \mathbb{R}$ függvények úgy, hogy $g$ értékkészlete az $f$ értelmezési tartományában fekszik. Ekkor az

$$
x \rightarrow f(g(x))
$$

hozzárendelést az $f$ és $g$ függvények kompozíciójának nevezzük. Jelölése $f \circ g$, azaz

$$
f \circ g(x)=f(g(x)) .
$$

Ha például $f(x)=\sqrt{x}$ és $g(x)=1+x^{2}$, akkor

$$
f \circ g(x)=\sqrt{1+x^{2}}
$$

\section{Figyelem, a sorrend fontos!}

Általában $f \circ g \neq g \circ f$. Ha a fenti példát tekintjük, akkor

$$
g \circ f(x)=1+x
$$

de ez a függvény csak $x \geq 0$ esetén van értelmezve!

Az is előfordulhat, hogy $f \circ g$ az egész számegyenesen értelmezve van, de $g \circ f$ nem is definiálható. Ha például

$$
f(x)=-1-x^{4} \quad \text { és } \quad g(x)=\sqrt{x},
$$

akkor $f \circ g(x)=-1-x^{2}$, ha $x \geq 0$, de $g \circ f(x)=\sqrt{-1-x^{4}}$ egyetlen valós számra sincs értelmezve. 


\subsection{Láncszabály}

A kompozíció-függvény differenciálhatóságáról szóló tételünk igen erős eszköz bonyolultabb függvények deriváltjának előállításhoz.

4.7 Tétel. (Láncszabály) Tegyük fel, hogy g differenciálható az x pontban, és $f$ differenciálható a $g(x)$ pontban, akkor $f \circ g$ is differenciálható az x pontban, és

$$
(f \circ g)^{\prime}(x)=f^{\prime}(g(x)) \cdot g^{\prime}(x)
$$

Ha bevezetjük a $k=g(x+h)-g(x)$ jelölést, akkor az $f \circ g$ függvény különbségi hányadosa az $x$ helyen a következô módon írható:

$$
\begin{aligned}
& \frac{f(g(x+h))-f(g(x))}{h}= \\
& \frac{f(g(x)+k)-f(g(x))}{k} \cdot \frac{g(x+h)-g(x)}{h}
\end{aligned}
$$

amennyiben $g(x+h)-g(x) \neq 0$. Ilyenkor $h \rightarrow 0$ esetén a $g$ folytonossága miatt $k \rightarrow 0$, és így a jobb oldali kifejezés határértéke

$$
f^{\prime}(g(x)) \cdot g^{\prime}(x)
$$

Ez a gondolat nem múködik akkor, ha $k=0$. Ekkor a bizonyítás egy kicsit komplikáltabb, ezt nem részletezzük.

4.8 Példa. Legyen például

$$
F(x)=\left(1+3 x-x^{2}\right)^{6}
$$

Ekkor a derivált a hatványozás elvégzése nélkül előállítható, ha észrevesszük, hogy az $f(x)=x^{6}$ és $g(x)=1+3 x-x^{2}$ jelölésekkel $F=f \circ g$. Tehát a tételünk szerint:

$$
F^{\prime}(x)=6\left(1+3 x-x^{2}\right)^{5} \cdot(3-2 x)
$$


4.9 Példa. Legyen most

$$
F(x)=\left(\frac{2 x+3}{5+x^{2}}\right)^{3} \quad x \in \mathbb{R}
$$

Ekkor a

$$
g(x)=\frac{2 x+3}{5+x^{2}} \quad \text { és } \quad f(x)=x^{3}
$$

jelölésekkel $F=f \circ g$. Vegyük figyelembe, hogy a $g$ hányadosként áll elő, így

$$
F^{\prime}(x)=f^{\prime}(g(x)) \cdot g^{\prime}(x)=3\left(\frac{2 x+3}{5+x^{2}}\right)^{2} \cdot \frac{2\left(5+x^{2}\right)-2 x(2 x+3)}{\left(5+x^{2}\right)^{2}}
$$

amelyet még valamivel egyszerűbb alakra hozhatunk.

\section{Otthoni tanuláshoz}

1. A Feladatgyưjtemény-1 I/3 és I/6 szakaszok kidolgozott példáinak feldolgozása.

2. Házi feladatok: az I/3 szakasz 3.1.4, 3.1.5, továbbá az I/6 szakasz 6.1.2, 6.1.4, 6.2.3, 6.2.7, 6.2.9 feladatai.

3. Tankönyv-1 4. fejezet, 5.2 és 5.6 szakaszok. 


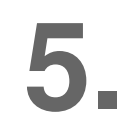

A KÖZÉPÉRTÉK-TÉTEL 



\subsection{Az inverz függvény}

Tekintsünk egy $f: \mathbb{R} \rightarrow \mathbb{R}$ függvényt, amely kölcsönösen egyértelmú valamely intervallumon. Ez például egy folytonos függvényre azt jelenti, hogy $f$ vagy szigorúan monoton növő, vagy szigorúan monoton fogyó.

5.1 Definíció. Az $f$ függvény inverzén azt az $f^{-1}$ függvényt értjük, amelynek értelmezési tartománya az $f$ értékkészlete, és értékkészlete az $f$ értelmezési tartománya, továbbá

$$
f^{-1} \circ f(x)=x
$$

az $f$ értelmezési tartományának minden pontjában.

Ezt a „fordított” hozzárendelést úgy állíthatjuk elő, hogy az

$$
y=f(x)
$$

egyenlőségből kifejezzük $x$-et $y$ függvényeként:

$$
x=f^{-1}(y) .
$$

Ha például $f(x)=(2 x+5)^{3}$, akkor világos, hogy

$$
f^{-1}(y)=\frac{\sqrt[3]{y}-5}{2}
$$

Világos, hogy $f^{-1}$ grafikonja és $f$ grafikonja az $y=x$ egyenesre nézve tükrös helyzetúek.

\subsection{Az inverz függvény differenciálhatósága}

5.2 Tétel. Tegyük fel, hogy $f$ folytonos, szigorúan monoton valamely intervallumon, differenciálható annak valamely $x$ belsố pontjában és $f^{\prime}(x) \neq 0$. Akkor $f^{-1}$ is differenciálható az $y=f(x)$ pontban, és

$$
\left(f^{-1}\right)^{\prime}\left(y_{0}\right)=\frac{1}{f^{\prime}\left(x_{0}\right)}
$$


Vázlatosan a következőről van szó. Tekintsük a különbségi hányadost:

$$
\frac{f^{-1}(y+h)-f^{-1}(y)}{h}
$$

Legyenek $x$ és $x+k$ olyan pontok az $f$ értelmezési tartományából, amelyekre $y=f(x)$ és $y+h=f(x+k)$. Akkor a különbségi hányados úgy írható, hogy

$$
\frac{x+k-x}{f(x+k)-f(x)}=\frac{1}{\frac{f(x+k)-f(x)}{k}}
$$

Ha itt $h \rightarrow 0$, akkor $k \rightarrow 0$ (FIGYELEM, nem nyilvánvaló!), és így a jobb oldali tört határértéke valóban $1 / f^{\prime}(x)$.

5.3 Példa. Határozzuk meg a

$$
g(x)=\sqrt[n]{x}
$$

függvény deriváltját valamely $x>0$ pontban. Ekkor $g$ éppen az $f(x)=x^{n}$ hatványfüggvény inverze a pozitív félegyenesen, azaz $g(y)=f^{-1}(y)$. Ezért

$$
g^{\prime}(y)=\frac{1}{f^{\prime}(x)}=\frac{1}{n x^{n-1}}=\frac{1}{n} \cdot y^{\frac{1}{n}-1}
$$

hiszen $y=x^{n}$ és így

$$
x^{n-1}=y^{\frac{n-1}{n}}
$$

Ezen példa alapján könnyen láthatjuk, hogy bármely $r$ racionális kitevő esetén az $F(x)=x^{r}$ függvény bármely $x>0$ pontban differenciálható, és

$$
F^{\prime}(x)=r x^{r-1}
$$

5.4 Példa. Állítsuk elő az

$$
F(x)=\sqrt{1+x^{4}}
$$

függvény deriváltját. Legyen $f(x)=\sqrt{x}$ és $g(x)=1+x^{4}$, ezekkel a jelölésekkel $F=$ $f \circ g$. Ezért

$$
F^{\prime}(x)=f^{\prime}(g(x)) \cdot g^{\prime}(x)=\frac{4 x^{3}}{2 \sqrt{1+x^{4}}}
$$




\subsection{Az exponenciális és a logaritmus függvény}

Tekintsük a számegyenesen az $e$ alapú exponenciális függvényt, és annak inverzét, az $e$ alapú logaritmus függvényt (ennek jelölésére az ln jel használatos):

$$
f(x)=e^{x} \quad f^{-1}(x)=\ln x \quad(x>0) .
$$

Ezeket természetes alapú exponenciális, illetve logaritmus függvénynek nevezzük. Ezen függvények deriváltjait szeretnénk előállítani. Ehhez felhasználjuk, hogy

$$
\lim _{x \rightarrow \pm \infty}\left(1+\frac{1}{x}\right)^{x}=e .
$$

Határozzuk meg a természetes alapú logaritmus függvény deriváltját az $x_{0}=1$ helyen.

$$
\frac{\ln (1+h)-\ln 1}{h}=\ln (1+h)^{1 / h}
$$

amelynek (feltételezve a logaritmus függvény folytonosságát) jobb és bal oldali határértéke egyaránt ln $e$ a 0 helyen. Tehát a derivált értéke 1.

Az $f(x)=e^{x}$ függvény deriváltját a 0 helyen az inverz függvény deriváltjára vonatkozó tételünk alapján határozhatjuk meg:

$$
f^{\prime}(0)=\lim _{h \rightarrow 0} \frac{e^{h}-1}{h}=\frac{1}{(\ln )^{\prime}(1)}=1 .
$$

Innen már könnyen megkapjuk az exponenciális függvény deriváltját tetszőleges $x$ pontban:

$$
f^{\prime}(x)=\lim _{h \rightarrow 0} \frac{e^{x+h}-e^{x}}{h}=e^{x} \cdot \lim _{h \rightarrow 0} \frac{e^{h}-1}{h}=e^{x}
$$

Ismét az inverz függvény deriválási szabályát alkalmazva adódik a logaritmus függvény deriváltja tetszóleges $x>0$ pontban:

$$
\left(f^{-1}\right)^{\prime}(x)=\frac{1}{e^{\ln x}}=\frac{1}{x} .
$$

5.5 Példa. Alkalmazásképpen állítsuk elő az

$$
f(x)=x^{\alpha}
$$

általános hatványfüggvény deriváltját valamely $x>0$ pontban, ahol $\alpha$ tetszőleges valós szám. Világos, hogy

$$
f(x)=x^{\alpha}=e^{\alpha \ln x}
$$

és így a kompozíció függvény deriválási szabálya folytán:

$$
f^{\prime}(x)=\alpha \frac{1}{x} e^{\alpha \ln x}=\alpha \frac{1}{x} x^{\alpha}=\alpha x^{\alpha-1}
$$

Ez azt jelenti, hogy a deriválás ugyanúgy végezhető el, mint racionális kitevő esetében. 


\subsection{A szélsőérték szükséges feltétele}

Tekintsünk egy $f: \mathbb{R} \rightarrow \mathbb{R}$ függvényt.

5.6 Definíció. Azt mondjuk, hogy az értelmezési tartomány valamely $x_{0}$ pontja az $f$ (globális) minimumhelye, ha $f\left(x_{0}\right) \leq f(x)$ az értelmezési tartomány bármely $x \neq x_{0}$ pontjára.

Azt mondjuk, hogy az értelmezési tartomány valamely $x_{0}$ pontja az $f$ lokális minimumhelye, ha létezik olyan $\varepsilon>0$ szám, hogy $f\left(x_{0}\right) \leq f(x)$ az értelmezési tartomány bármely olyan $x$ pontjára, amelyre $0<\left|x-x_{0}\right|<\varepsilon$.

Mindkét esetben szigorú minimumhelyről beszélünk, ha szigorú egyenlőtlenség teljesül.

Analóg definíció érvényes maximum esetében.

Nyilvánvaló, hogy egy globális minimumhely egyben lokális minimumhely is, a megfordítás azonban nem érvényes. Például az

$$
f(x)= \begin{cases}(x+1)^{2} & \text { ha } x<0 \\ (x-1)^{2} & \text { ha } x \geq 0\end{cases}
$$

függvénynek az $x=0$ pontban lokális maximumhelye van (itt a függvény folytonos, de nem differenciálható, ellenőrizzük!), de a függvénynek nincs is globális maximumhelye, hiszen felülrôl nem korlátos.

Differenciálható függvények esetében a szélsőértékhely következő karakterizációját adhatjuk.

5.7 Tétel. Tegyük fel, hogy f egy intervallumon értelmezett függvény, és ennek valamely $x_{0}$ belsö pontjában $f$ differenciálható. Ha $x_{0}$ az $f$ lokális minimumhelye, akkor $f^{\prime}\left(x_{0}\right)=$ 0 .

Valóban, tekintsük a különbségi hányadost:

$$
\frac{f\left(x_{0}+h\right)-f\left(x_{0}\right)}{h} .
$$

Ha $h>0$, akkor a különbségi hányados a $h$ elég kicsi értékeire nem negatív, így a jobb oldali határérték is nem negatív. Másrészt ha $h<0$, akkor hasonlóképpen a különbségi hányados nem pozitív, ezért a bal oldali határérték is nem pozitív. A differenciálhatósági feltétel folytán azonban a különbségi hányadosnak létezik határértéke, ami így csak nulla lehet. Tehát $f^{\prime}\left(x_{0}\right)=0$.

Ez a tételünk a szélsőérték szükséges feltételét fogalmazza meg, amely azonban nem elégséges. Például az $f(x)=x^{3}$ függvénynek nincs szélsőértékhelye, de $f^{\prime}(0)=0$.

Egy differenciálható függvény esetében azon $x_{0}$ pontokat, amelyben $f^{\prime}\left(x_{0}\right)=0$, a függvény kritikus pontjainak nevezzük.

Ezzel a szóhasználattal az értelmezési tartomány belső pontjai között minden szélsôértékhely kritikus pont, de ennek megfordítása nem érvényes. 


\subsection{Lagrange-féle középérték-tétel}

A geometriai interpretáció alapján szemléletes állítást fogalmaz meg a Lagrange-féle középérték-tétel:

5.8 Tétel. Legyen $f$ folytonos az $[a, b]$ véges, zárt intervallumon és differenciálható $a z$ intervallum belsejében. Akkor található olyan $\xi \in(a, b)$ pont, amelyre

$$
f^{\prime}(\xi)=\frac{f(b)-f(a)}{b-a}
$$

Bizonyítás. Tekintsük ugyanis a

$$
g(x)=f(x)-f(a)-\frac{f(b)-f(a)}{b-a}(x-a)
$$

függvényt. Ez a függvény a feltételünk szerint folytonos az $[a, b]$ intervallumon, így Weierstrass tétele értelmében felveszi a minimumát és a maximumát az $[a, b]$ intervallumon. A minimum és a maximumhely közül legalább az egyik létezik az intervallum belsejében, hiszen

$$
g(a)=g(b)=0 .
$$

Ha ez a szélsőértékhely $\xi \in(a, b)$, akkor az előző tételünk értelmében $g^{\prime}(\xi)=0$. Ez éppen azt jelenti, hogy

$$
f^{\prime}(\xi)-\frac{f(b)-f(a)}{b-a}=0 .
$$

Vegyük észre, hogy a tételünkben a folytonosssági feltevés lényeges, készítsünk ábrát!

\subsection{L'Hôpital-szabály}

Az alábbi eljárás megkönnyíti határértékek kiszámítását.

Legyenek $f$ és $g$ egyaránt differenciálhatók az $x_{0}$ pontban, és tegyük fel, hogy $f\left(x_{0}\right)=g\left(x_{0}\right)=0$. Képzeljük el, hogy a

$$
\lim _{x \rightarrow x_{0}} \frac{f(x)}{g(x)}
$$

határértéket kell meghatároznunk (amely így 0/0 „határozatlan” alakú). 
Tegyük fel, hogy $g^{\prime}\left(x_{0}\right) \neq 0$. Ekkor

$$
\frac{f(x)}{g(x)}=\frac{\frac{f(x)-f\left(x_{0}\right)}{x-x_{0}}}{\frac{g(x)-g\left(x_{0}\right)}{x-x_{0}}}
$$

Itt $x \rightarrow x_{0}$ esetén a jobb oldali törtben a számlálónak és a nevezőnek is létezik véges határértéke, és ez a nevezőben nem nulla, tehát

$$
\lim _{x \rightarrow x_{0}} \frac{f(x)}{g(x)}=\frac{f^{\prime}\left(x_{0}\right)}{g^{\prime}\left(x_{0}\right)}
$$

Ezt az egyenlőséget L’Hôpital-szabálynak nevezzük.

5.9 Példa. Tekintsük például a

$$
\lim _{x \rightarrow 0} \frac{2 \sin x}{1-\sqrt{1+x}}
$$

határértéket. Ekkor a L'Hôpital-szabály szerint:

$$
\lim _{x \rightarrow 0} \frac{2 \sin x}{1-\sqrt{1+x}}=\frac{2 \cos 0}{-\frac{1}{2 \sqrt{1+0}}}=-4
$$

\section{Otthoni tanuláshoz}

1. A Feladatgyújtemény-1 I/3, I/6 és I/7 szakaszok kidolgozott példáinak feldolgozása.

2. Házi feladatok: az I/3 szakasz 3.2.3, 3.2.4, 3.2.5, továbbá az I/6 szakasz 6.3.5, 6.3.6, 6.3.10, továbbá az I/7 szakasz 7.1.6, 7.1.8 és 7.1.9 feladatai

3. Tankönyv-1 5.1, 5.4, 7.5 és 7.6 szakaszok, 8. fejezet. 


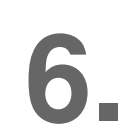

A TELJES FÜGGVÉNYVIZSGÁLAT 



\subsection{Monoton függvények}

6.1 Definíció. Azt mondjuk, hogy $f$ valamely intervallumon monoton növő, ha az intervallum bármely két $x_{1}<x_{2}$ pontjára $f\left(x_{1}\right) \leq f\left(x_{2}\right)$. Analóg a monoton fogyó függvény értelmezése.

Szigorú monotonitásról beszélünk, ha az utóbbi egyenlőtlenség szigorú formában teljesül.

6.2 Tétel. Legyen $f$ folytonos az $[a, b]$ véges, zárt intervallumon és differenciálható az intervallum belsejében. Ha minden belsố pontban $f^{\prime}(x)>0$, akkor $f a z[a, b]$ intervallumon szigorúan monoton növó.

Valóban, ha $x_{1}<x_{2}$ az $[a, b]$ intervallum két tetszőleges pontja, akkor a Lagrange-féle középérték-tétel szerint található olyan $x_{1}<\xi<x_{2}$ pont, amelyre

$$
f\left(x_{2}\right)-f\left(x_{1}\right)=f^{\prime}(\xi)\left(x_{2}-x_{1}\right) \text {. }
$$

A feltételünk szerint a jobb oldalon álló kifejezés pozitív, ezért

$$
f\left(x_{2}\right)-f\left(x_{1}\right)>0
$$

azaz $f$ valóban szigorúan monoton növő.

Vizsgáljunk most meg egy intervallumon monoton növő, differenciálható függvényt. Könnyen látható, hogy az intervallum bármely két különböző $x$ és $x+h$ pontjára fennáll

$$
\frac{f(x+h)-f(x)}{h} \geq 0
$$

tehát a $h \rightarrow 0$ határértékre térve $f^{\prime}(x) \geq 0$. Ezt az észrevételt az előző tételünkkel egybevetve a következó állítást fogalmazhatjuk meg:

6.3 Tétel. Legyen $f$ folytonos az $[a, b]$ intervallumon és differenciálható az intervallum belsejében. Az $f$ függvény akkor és csak akkor monoton növö az intervallumon, ha $f^{\prime}(x) \geq 0$ az intervallum minden belsó pontjában.

Hasonló állítás érvényes a monoton fogyó esetben is.

Az azonban nem igaz, hogy ha $f$ szigorúan monoton növő, akkor $f^{\prime}(x)>0$ lenne minden $x$ pontban. Például az $f(x)=x^{3}$ függvény az egész számegyenesen szigorúan monton növő, de $f^{\prime}(0)=0$. 


\subsection{A szélsőértékhely megkeresése}

Tekintsünk egy $f: \mathbb{R} \rightarrow \mathbb{R}$ függvényt, és legyen $x_{0}$ az értelmezési tartomány belső pontja. Tegyük fel, hogy $f$ differenciálható az $x_{0}$ pontban.

Amint láttuk, annak szükséges feltétele, hogy $x_{0}$ szélsőértékhely legyen, az, hogy $f^{\prime}\left(x_{0}\right)=0$. Kérdés, hogy milyen elégséges feltételt fogalmazhatunk meg a szélsőérték létezésére. Világos, hogy ha található olyan $\varepsilon>0$ szám, amelyre $f$ monoton fogyó az $\left[x_{0}-\varepsilon, x_{0}\right]$ intervallumon, továbbá $f$ monoton növő az $\left[x_{0}, x_{0}+\varepsilon\right]$ intervallumon, akkor $x_{0}$ az $f$ lokális minimumhelye.

Differenciálható függények esetében ezt az észrevételünket az alábbi tételben fogalmazzuk meg.

6.4 Tétel. Tegyük fel, hogy $f$ differenciálható egy intervallumban és $x_{0}$ az intervallum belsố pontja. Ha van olyan $\varepsilon>0$ szám, hogy

- $f^{\prime}(x) \leq 0$, ha $x \in\left(x_{0}-\varepsilon, x_{0}\right)$

- $f^{\prime}(x) \geq 0$, ha $x \in\left(x_{0}, x_{0}+\varepsilon\right)$

akkor $x_{0}$ az $f$ lokális minimumhelye.

Nyilván analóg állítás érvényes lokális maximumhely esetére is.

6.5 Példa. Keressük meg az

$$
f(x)=x^{2} e^{-x}
$$

függvény szélsőértékeit és monotonitási szakaszait. Könnyen látható, hogy

$$
f^{\prime}(x)=\left(2 x-x^{2}\right) e^{-x}
$$

amelynek előjele csak az első tényezőtől függ. Ennek alapján a következőt kapjuk.

- Ha $x \in(-\infty, 0)$, akkor $f^{\prime}(x)<0$, ezért itt $f$ monoton fogyó

- Ha $x=0$, akkor $f^{\prime}(0)=0$, ez kritikus pont

- Ha $x \in(0,2)$, akkor $f^{\prime}(x)>0$, ezért itt $f$ monoton növő

- Ha $x=2$, akkor $f^{\prime}(2)=0$, ez kritikus pont

- Ha $x \in(2,+\infty)$, akkor $f^{\prime}(x)<0$, ezért itt $f$ monoton fogyó

Az $f^{\prime}$ előjelváltásai alapján láthatjuk, hogy az $x=0$ pont (globális) minimumhely, míg $x=2$ lokális maximumhely. 
6.6 Példa. Tekintsük például a számegyenesen az

$$
f(x)=x+\sin x
$$

függvényt. Mivel $f^{\prime}(x)=1+\cos x$, világos, hogy a függvénynek az

$$
x=(2 k+1) \pi \quad k=0, \pm 1, \pm 2, \ldots
$$

helyeken kritikus pontjai vannak. Ezek közül azonban egyikben sem lehet szélsőérték, ugyanis

$$
x \neq(2 k+1) \pi \quad \text { esetén } \quad f^{\prime}(x)>0,
$$

hiszen ezekben a pontokban $\cos x>-1$.

Ez a függvény tehát az egész számegyenesen szigorúan monoton növő.

\subsection{Magasabbrendú deriváltak}

Ha egy $f$ függvény egy intervallumban mindenütt differenciálható, akkor az $x \rightarrow f^{\prime}(x)$ hozzárendelést az $f$ derivált-függvényének nevezzük. Ha $f^{\prime}$ differenciálható valamely $x_{0}$ pontban, akkor azt mondjuk, hogy $f$ itt kétszer differenciálható. Ilyenkor az $\left(f^{\prime}\right)^{\prime}\left(x_{0}\right)$ jelölés helyett az

$$
f^{\prime \prime}\left(x_{0}\right)
$$

jelölést használjuk, és ezt az $f$ második deriváltjának nevezzük az $x_{0}$ pontban.

Teljesen hasonlóan tetszóleges $n$ természetes szám esetén beszélhetünk az $f n$-ik deriváltjáról az $x_{0}$ pontban, ennek jelölése

$$
f^{(n)}\left(x_{0}\right) \text {. }
$$

Például az $f(x)=1 / x$ függvényre valamely $x_{0} \neq 0$ pontban

$$
f^{\prime \prime}\left(x_{0}\right)=\frac{2}{x_{0}^{3}} \quad \text { valamint } \quad f^{(n)}\left(x_{0}\right)=\frac{(-1)^{n} n !}{x^{n+1}}
$$

minden $n$ természetes számra.

6.7 Példa. Tekintsük az $f(x)=\sin x$ függvényt, és állítsuk elő a derivált-függvényét. Egyrészt

$$
\begin{aligned}
f^{\prime}(x) & =\lim _{h \rightarrow 0} \frac{\sin (x+h)-\sin x}{h}=\lim _{h \rightarrow 0} \frac{\sin x \cos h+\cos x \sin h-\sin x}{h} \\
& =\sin x \cdot \lim _{h \rightarrow 0} \frac{\cos h-1}{h}+\cos x \cdot \lim _{h \rightarrow 0} \frac{\sin h}{h}
\end{aligned}
$$


Itt a 3.12 Példa alapján az első határérték 0, míg a 3.8 Példa szerint a második határérték 1. Eszerint

$$
f^{\prime}(x)=\cos x
$$

Teljesen hasonló eljárással mutatható meg, hogy

$$
(\cos x)^{\prime}=-\sin x
$$

Tehát az $f(x)=\sin x$ függvény magasabbrendű deriváltjaira az alábbi eredmény adódik:

$$
f^{(n)}(x)=\left\{\begin{aligned}
\cos x & \text { ha } n \text { 4-gyel osztva } 1 \text { maradékot ad } \\
-\sin x & \text { ha } n \text { 4-gyel osztva } 2 \text { maradékot ad } \\
-\cos x & \text { ha } n \text { 4-gyel osztva } 3 \text { maradékot ad } \\
\sin x & \text { ha } n \text { 4-gyel osztható }
\end{aligned}\right.
$$

\subsection{Másodrendű feltételek}

Előfordulhat, hogy olyan bonyolult függvényt kell vizsgálunk, amelynél a derivált előjelét nehéz meghatározni. Ilyen esetekben bizonyulhat hasznosnak a szélsőérték másodrendû (elégséges) feltétele.

6.8 Tétel. Legyen $f$ differenciálható valamely intervallumban, és tegyük fel, hogy az intervallum valamely $x_{0}$ belsö pontjában $f$ kétszer differenciálható.

Ha $f^{\prime}\left(x_{0}\right)=0$ és $f^{\prime \prime}\left(x_{0}\right)>0$, akkor $x_{0}$ az $f$ lokális minimumhelye.

Valóban, a különbségi hányados vizsgálata alapján

$$
\begin{aligned}
f^{\prime \prime}\left(x_{0}\right) & =\lim _{h \rightarrow 0} \frac{f^{\prime}\left(x_{0}+h\right)-f^{\prime}\left(x_{0}\right)}{h}= \\
& =\lim _{h \rightarrow 0} \frac{f^{\prime}\left(x_{0}+h\right)}{h}>0
\end{aligned}
$$

és ez azt jelenti, hogy az $f^{\prime}\left(x_{0}+h\right) / h$ hányados pozitív, ha $0<|h|<\varepsilon$ valamely $\varepsilon>0$ mellett. Innen adódik, hogy

- ha $x \in\left(x_{0}-\varepsilon, x_{0}\right)$, akkor $f^{\prime}(x)<0$,

- ha $x \in\left(x_{0}, x_{0}+\varepsilon\right)$, akkor $f^{\prime}(x)>0$.

Tehát a 6.4 Tételünk alapján $x_{0}$ valóban lokális minimumhely.

Természetesen analóg elégséges feltételt fogalmazhatunk meg a lokális maximumhely esetére is. 
Indirekt meggondolással azonnal kapjuk a szélsőérték másodrendú szükséges feltételét is.

6.9 Tétel. Tegyük fel, hogy $f$ kétszer differenciálható egy intervallumban, és legyen $x_{0}$ az intervallum valamely belsó pontja.

- Ha $x_{0}$ lokális minimumhely, akkor $f^{\prime}\left(x_{0}\right)=0$, és $f^{\prime \prime}\left(x_{0}\right) \geq 0$.

- Ha $x_{0}$ lokális maximumhely, akkor $f^{\prime}\left(x_{0}\right)=0$, és $f^{\prime \prime}\left(x_{0}\right) \leq 0$.

6.10 Példa. Legyen például $x>0$ esetén

$$
f(x)=x \ln x
$$

Ekkor $f^{\prime}(x)=1+\ln x$, tehát az $f$ függvény egyetelen kritikus pontja $x=1 / e$. Mivel $f^{\prime \prime}(x)=1 / x$, ezen a helyen

$$
f^{\prime \prime}(1 / e)=e>0,
$$

tehát az $f$ függvénynek az $x=1 / e$ helyen lokális minimumhelye van. Nem nehéz belátni, hogy ez egyben globális minimum is.

Vegyük észre, hogy az eddigi tételeink nem tartalmaznak információt egy olyan $x_{0}$ kritikus pont esetében, ahol

$$
f^{\prime \prime}\left(x_{0}\right)=0
$$

Ennek az az oka, hogy ebben a ,határesetben” bármi előfordulhat. Vizsgáljuk meg ugyanis az

$$
f(x)=x^{n} \quad(n \geq 3)
$$

hatványfüggvény viselkedését az $x_{0}=0$ kritikus pontban. Világos, hogy itt $f^{\prime}(0)=0$ és $f^{\prime \prime}(0)=0$. Másrészt

- ha $n$ páros, akkor $x_{0}=0$ (globális) minimumhely,

- ha $n$ páratlan, akkor $x_{0}=0$ nem szélsőértékhely.

Teljesen hasonlóan páros $n$ esetén $x_{0}=0 \mathrm{a}-f$ függvénynek (globális) maximumhelye. 


\subsection{Konvex és konkáv függvények}

6.11 Definíció. Az $f$ függvényt konvexnek nevezzük az $[a, b]$ intervallumon, ha az intervallum tetszőleges $x_{1}$ és $x_{2}$ pontjaira és bármely $0 \leq \alpha \leq 1$ valós számra

$$
f\left(\alpha x_{1}+(1-\alpha) x_{2}\right) \leq \alpha f\left(x_{1}\right)+(1-\alpha) f\left(x_{2}\right) .
$$

Ez geometriailag azt jelenti, hogy a függvény grafikonjához rajzolt húr sehol sem lehet a függvény grafikonja alatt.

Konkáv függvényeket a fordított irányú egyenlőtlenséggel értelmezzük.

Kétszer differenciálható függvényekre a konvexitásnak egy igen egyszerú, és geometriailag is világos jellemzését adhatjuk.

6.12 Tétel. Tegyük fel, hogy f folytonos valamely intervallumon és kétszer differenciálható az intervallum belsejében. Annak szükséges és elégséges feltétele, hogy $f$ konvex az intervallumon:

$$
f^{\prime \prime}(x) \geq 0
$$

az intervallum minden belsố pontjában.

Ez azt jelenti, hogy konvex függvény esetében az érintő meredeksége monoton növő. Ezt úgy is szemléltethetjük, hogy egy konvex függvény esetében a függvény grafikonja sehol sincs az érintő alatt.

6.13 Példa. Vizsgáljuk meg az

$$
f(x)=\frac{x}{1+x^{2}}
$$

függvényt. Könnyen ellenőrizhetjük, hogy

$$
f^{\prime}(x)=\frac{1-x^{2}}{\left(1+x^{2}\right)^{2}} .
$$

A derivált előjelének vizsgálata alapján

- $f$ szigorúan monoton fogyó a $(-\infty,-1)$ intervallumon

- $x=-1$ (globális) minimumhely

- $f$ szigorúan monoton növő a $(-1,1)$ intervallumon

- $x=1$ (globális) maximumhely 
- $f$ szigorúan monoton fogyó a $(1,+\infty)$ intervallumon

A konvexitást a második derivált előjele alapján vizsgálhatjuk:

$$
f^{\prime \prime}(x)=\frac{2 x^{3}-6 x}{\left(1+x^{2}\right)^{3}}
$$

Világos, hogy a nevező minden pontban pozitív, ezért elég a

$$
2 x^{3}-6 x=2 x\left(x^{2}-3\right)
$$

számláló előjelét tekinteni. Tehát

- $f$ konkáv a $(-\infty,-\sqrt{3})$ intervallumon

- $f$ konvex a $(-\sqrt{3}, 0)$ intervallumon

- $f$ konkáv a $(0, \sqrt{3})$ intervallumon

- $f$ konvex a $(\sqrt{3},+\infty)$ intervallumon

Vegyük észre, hogy $f^{\prime \prime}(-\sqrt{3})=f^{\prime \prime}(0)=f^{\prime \prime}(\sqrt{3})=0$, és ezekben a pontokban a második derivált előjelet vált. Ezek a pontok tehát az $f$ függvény konvex és konkáv szakaszait választják el. Az ilyen pontokat az $f$ inflexiós pontjainak nevezzük.

Inflexiós pontban az érintő átmetszi a függvény grafikonját.

A konvex függvények egyik legfontosabb tulajdonsága, hogy a lokális és a globális minimumhely fogalma egybeesik.

6.14 Tétel. Tekintsünk egy $f$ kétszer differenciálható konvex függvényt egy intervallumon, és legyen $x_{0}$ az intervallum egy belsó pontja. Ha $x_{0}$ lokális minimumhely, akkor globális minimumhely is.

Valóban, a feltételeink szerint $f^{\prime}\left(x_{0}\right)=0$, másrészt a konvexitás miatt $f^{\prime}$ monoton növő. Ezért az intervallum belső pontjaiban

- $x<x_{0}$ esetén $f^{\prime}(x) \leq 0$,

- $x>x_{0}$ esetén $f^{\prime}(x) \geq 0$.

Innen az $f^{\prime}$ monotonitása miatt adódik az állítás.

Természetesen most is analóg állítást fogalmazhatunk meg konkáv függvények maximumhelyére vonatkozóan.

\section{Otthoni tanuláshoz}

1. A Feladatgyưjtemény-1 I/6 és I/7 szakaszok kidolgozott példáinak feldolgozása.

2. Házi feladatok: az I/6 szakasz 6.6.3, 6.6.4, 6.6.6, 6.6.8, továbbá az I/7 szakasz 7.3.4, 7.3.7, 7.3.8 feladatai.

3. Tankönyv-1 9. fejezet. 



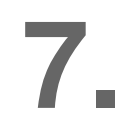

INTEGRÁLÁS 



\subsection{A határozatlan integrál fogalma}

7.1 Definíció. Legyen $f$ valamely $I$ intervallumon értelmezett függvény. Azt mondjuk, hogy az $I$ intervallumon értelmezett differenciálható $F$ függvény az $f$ határozatlan integrálja, vagy más elnevezéssel primitív függvénye, ha

$$
F^{\prime}(x)=f(x)
$$

minden $x \in I$ esetén.

Világos, hogy a határozatlan integrál a deriválás fordított múvelete. A határozatlan integrál fogalma azonban nem egyértelmú! Ha ugyanis egy $F$ függvény az $f$ határozatlan integrálja, akkor ahhoz bármely $C$ konstanst adva ugyancsak határozatlan integrálhoz jutunk. Valóban:

$$
(F(x)+C)^{\prime}=F^{\prime}(x)=f(x)
$$

minden $x$ pontban.

Beláthatjuk, hogy más típusú határozatlan integrál nem is létezhet.

7.2 Tétel. Ha $F$ az $f$ határozatlan integrálja az I intervallumon, akkor az $f$ minden határozatlan integrálja $F+C$ alakú valamely $C$ konstans mellett.

Bizonyítás. Valóban, ha a $G$ differenciálható függvény is az $f$ határozatlan integrálja az $I$ intervallumon, akkor minden $x \in I$ pontban

$$
(F(x)-G(x))^{\prime}=f(x)-f(x)=0
$$

Ez azt jelenti, hogy $F-G$ deriváltja az $I$ intervallumon zérus, ezért a Lagrange-féle középérték-tétel miatt $F-G$ konstans ezen az intervallumon.

A fenti tételünknek megfelelően a következő jelölésmódot használjuk a határozatlan integrálokra:

$$
\int f(x) d x=F(x)+C
$$

Például közvetlen deriválással ellenőrizhető, hogy

$$
\int \cos x d x=\sin x+C
$$

vagy teljesen hasonlóan

$$
\int x^{\alpha} d x=\frac{x^{\alpha+1}}{\alpha+1}+C \quad(\alpha \neq-1)
$$

tetszóleges $C$ konstans mellett. Ez azt mutatja, hogy ha egy függvénynek egy intervallumon van határozatlan integrálja, akkor végtelen sok is van. 


\subsection{Alapintegrálok}

Számos határozatlan integrál kiszámításakor segít az alábbi szabály:

7.3 Tétel. $\int(\alpha f(x)+\beta g(x)) d x=\alpha \int f(x) d x+\beta \int g(x) d x$

Ez a szabály természetesen tetszőleges véges tagú összegre általánosítható.

Figyelem: Nem minden függvénynek van határozatlan integrálja! Ha például az $f$ függvénynek olyan szakadási pontja van, amelyben a jobb és bal oldali határértékek végesek, de különbözőek, akkor nem létezhet határozatlan integrál. Az alábbi tétel hasznos elégséges feltételt fogalmaz meg.

7.4 Tétel. Ha f folytonos az I intervallumon, akkor létezik határozatlan integrálja.

Határozatlan integrálok meghatározására szabályokat a deriválási szabályok megfordításával nyerhetünk. Az elemi függvények deriváltjait megadó formulákat megfordítva az elemi függvények határozatlan integráljaihoz jutunk, ezeket nevezzük alapintegráloknak. Az alapintegrálokat összefoglaló listát találunk a Feladatgyújtemény-1-ben, TANULMÁNYOZZUK RÉSZLETESEN!

\subsection{Kezdetiérték-feladatok}

Az előzőekben láttuk, hogy egy függvénynek végtelen sok határozatlan integrálja lehet, amelyek csak konstansban különbözhetnek egymástól. Ha azonban a koordinátarendszer egy pontját rögzítjük, azon már csak egyetlen határozatlan integrál halad át.

7.5 Példa. Keressük meg azt az $F$ függvényt, amelyre

$$
F^{\prime}(x)=2 e^{-x} \quad \text { és } \quad F(0)=1
$$

Ekkor

$$
F(x)=2 \int e^{-x} d x=-2 e^{-x}+C
$$

Innen a kezdeti értékre vonatkozó feltételből $C=3$ adódik.

\subsection{Határozott integrálok}

Ebben a szakaszban röviden felvázoljuk azt, ahogy Bernhard Riemann német matematikus, a göttingeni egyetem professzora értelmezte a határozott integrál fogalmát a 
XIX. században. Ez az elképzelés az Arkhimédesz-féle kétoldali közelítés elvén alapul, ami az emberi gondolkodás egyik meghatározó eleme (és ez volt az az eljárás, ahogy az ókori Szirakuzában Archimedes meghatározta a kör területét a belülrôl és kívülről közelítő szabályos sokszögek területei alapján).

Legyen $f$ folytonos függvény az $[a, b]$ véges intervallumon, és tekintsük az intervallum egy

$$
a=x_{0}<x_{1}<\ldots<x_{n}=b
$$

felosztását $n$ számú részintervallumra. Minden egyes $\left[x_{k-1}, x_{k}\right]$ részintervallumon jelentse $m_{k}$ az $f$ függvény legkisebb, és $M_{k}$ a legnagyobb értékét, amelyek Weierstrass tétele értelmében léteznek. Készítsük el az

$$
s_{n}=\sum_{k=1}^{n} m_{k}\left(x_{k}-x_{k-1}\right)
$$

úgynevezett alsó összeget, illetve az

$$
S_{n}=\sum_{k=1}^{n} M_{k}\left(x_{k}-x_{k-1}\right)
$$

felső összeget. Ezen téglalapok területeinek összegei, az $f$ grafikonja alatti területet alulról, illetve felülről közelítik. KÉSZÍTSÜNK ÁBRÁT!

Könnyen ellenőrizhetjük, hogy újabb osztópont beiktatásával $s_{n}$ nem csökkenhet, míg $S_{n}$ nem nôhet. Megmutatható, hogy a felosztás súrítésével az alsóösszegek felső határa megegyezik a felső összegek alsó határával. Riemann értelmezésében ezt a közös $S$ értéket az $f$ függvény határozott integráljának nevezzük az $[a, b]$ véges intervallumon, jelölésben:

$$
S=\int_{a}^{b} f(x) d x
$$

ami az $f$ függvény grafikonja alatti (előjeles!) területet jelenti.

Megfogalmazzuk a határozott integrál néhány fontos tulajdonságát, amelyeket természetesnek látunk az integrál geometriai interpretációja alapján.

7.6 Tétel. Legyenek $f$ és g olyan függvények, amelyeknek létezik integrálja.

1. Ha $f(x) \leq g(x) a z[a, b]$ intervallumon, akkor

$$
\int_{a}^{b} f(x) d x \leq \int_{a}^{b} g(x) d x
$$

2. Speciálisan, $\left|\int_{a}^{b} f(x) d x\right| \leq \int_{a}^{b}|f(x)| d x$.

3. Speciálisan, ha $f(x) \leq M a z[a, b]$ intervallumon (M konstans) akkor

$$
\int_{a}^{b} f(x) d x \leq M(b-a)
$$


4. Ha folytonos $a z[a, b]$ intervallumon, akkor található olyan $\bar{x} \in[a, b]$, amelyre $\int_{a}^{b} f(x) d x=f(\bar{x})(b-a)$.

5. $\int_{a}^{c} f(x) d x=\int_{a}^{b} f(x) d x+\int_{b}^{c} f(x) d x$

Készítsünk ábrákat, amelyeken értelmezzük a fenti állításokat!

\subsection{Newton-Leibniz-formula}

Ebben a szakaszban megvizsgáljuk, hogy a határozott integrál hogyan számítható ki a primitív függvény ismeretében.

7.7 Tétel. (Newton-Leibniz-formula) $H a F$ az f folytonos függvény primitív függvénye az $[a, b]$ véges intervallumon, akkor

$$
\int_{a}^{b} f(x) d x=F(b)-F(a)
$$

Indoklás (nem bizonyítás!): Világos, hogy az állításunk nem függ attól, hogy melyik határozatlan integrált választottuk. Ha ugyanis $G$ is az $f$ függvény határozatlan integrálja, akkor

$$
G(x)=F(x)+C
$$

alakú az $[a, b]$ intervallumon, valamely $C$ konstans mellett a 7.2 Tétel értelmében. Tehát ekkor

$$
\int_{a}^{b} f(x) d x=[G(x)]_{a}^{b}=G(b)-G(a)=(F(b)+C)-(F(a)+C)=F(b)-F(a) .
$$

Másrészt tekintsük tetszőleges $x \in[a, b]$ mellett az

$$
F(t)=\int_{a}^{t} f(x) d x
$$

integrált. Ekkor $F(a)=0$, hiszen ekkor az integrálási út hossza zérus. Elég belátnunk, hogy $F$ az $f$ határozatlan integrálja.

Valóban, ekkor tetszőleges $a<t<b$ és olyan $h \neq 0$ esetén, amelyre $t+h \in[a, b]$, az integrál tulajdonságai alapján található olyan $\bar{x}$ a $t$ és a $t+h$ pontok között, amelyre

$$
\frac{1}{h}(F(t+h)-F(t))=\frac{1}{h} \int_{t}^{t+h} f(x) d x=\frac{1}{h} f(\bar{x}) \cdot h
$$

Ha most $h \rightarrow 0$, akkor $\bar{x} \rightarrow t$, ezért $f$ folytonossága miatt $f(\bar{x}) \rightarrow f(t)$, azaz

$$
\lim _{h \rightarrow 0} \frac{1}{h}(F(t+h)-F(t))=F^{\prime}(t)=\lim _{h \rightarrow 0} f(\bar{x})=f(t)
$$

tehát $F$ valóban $f$ primitív függvénye. 
Newton és Lebniz, és a korabeli matematika fantasztikus teljesítménye volt, hogy a határozott integrál geometriai fogalmát kapcsolatba tudta hozni a derivált fogalmával a tételünkben megfogalmazott módon.

Ez a felismerés hihetlen gyors fejlődést eredményezett elôször a fizika és a kémia, majd némi késéssel a biológia és a közgazdaságtan kvantitatív elemzésében is. Összességében azt mondhatjuk, hogy meghatározó szerepe volt a precíz tudományos nyelvezet létrejöttében minden tudományterületen.

A fenti bizonyítás egy következményeként fogalmazhatjuk meg a következő állítást.

7.8 Következmény. Ha f folytonos egy intervallumon, akkor ott van primitív függvénye.

Bizonyítás. Valóban, a fenti bizonyítás szerint az

$$
F(t)=\int_{a}^{t} f(x) d x
$$

függvény az $f$ primitív függvénye.

7.9 Példa. Számítsuk ki például az alábbi határozott integrált.

$$
\int_{1}^{2}\left(2 x^{3}+1+\frac{1}{x^{2}}\right) d x=\left[\frac{x^{4}}{2}+x-\frac{1}{x}\right]_{1}^{2}=9
$$

\section{Otthoni tanuláshoz}

1. A Feladatgyưjjtemény-1 I/9 és I/10 szakaszai kidolgozott példáinak feldolgozása.

2. Házi feladatok: az I/9 szakasz 9.1.7, 9.1.10, 9.1.17, 9.2.9, 9.2.11, 9.2.14, valamint az I/10 szakasz 10.1.6, 10.1.9, 10.1.13 és 10.1 .14 feladatai.

3. Tankönyv-1 10. fejezete. 



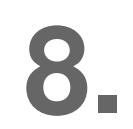

INTEGRÁLÁSI TECHNIKÁK 



\subsection{Parciális integrálás}

Ha $f$ és $g$ folytonosan differenciálható függvények valamely $I$ intervallumon, akkor a szorzat differenciálási szabálya alapján:

$$
\int f^{\prime}(x) g(x) d x=f(x) g(x)-\int f(x) g^{\prime}(x) d x
$$

Ezt a formulát parciális integrálásnak nevezzük. Tekintsük például az

$$
\int x e^{-x} d x
$$

integrált, akkor az $f^{\prime}(x)=e^{-x}$ és a $g(x)=x$ szereposztással (lehetne máshogy?):

$$
\int x e^{-x} d x=-x e^{-x}+\int e^{-x} d x=-x e^{-x}-e^{-x}+C
$$

8.1 Példa. Tekintsük példaként az

$$
\int x^{n} \ln x d x
$$

integrált. Integráljunk parciálisan az $f^{\prime}(x)=x^{n}$ és $g(x)=\ln x$ szereposztással (mit kapnánk a fordított szereposztással?):

$$
\int x^{n} \ln x d x=\frac{x^{n+1}}{n+1} \ln x-\int \frac{x^{n}}{n+1} d x=\frac{x^{n+1}}{n+1} \ln x-\frac{x^{n+1}}{(n+1)^{2}}+C
$$

Speciálisan $n=0$ esetén:

$$
\int \ln x d x=x \ln x-x+C=x(\ln x-1)+C
$$

\subsection{Parciális integrálás határozott integrálokra}

A parciális integrálást használhatjuk határozott integrálok kiszámítására az alábbi módon:

$$
\int_{a}^{b} f^{\prime}(x) g(x) d x=[f(x) g(x)]_{a}^{b}-\int_{a}^{b} f(x) g^{\prime}(x) d x
$$

Például az $f^{\prime}(x)=\sin x$ és $g(x)=x$ szereposztással (vajon a fordított jó lenne?):

$$
\begin{aligned}
\int_{0}^{\pi} x \sin x d x & =[-x \cos x]_{0}^{\pi}+\int_{0}^{\pi} \cos x d x \\
& =\pi+[\sin x]_{0}^{\pi}=\pi
\end{aligned}
$$


Ez az eljárás általában gyorsabb, mint először a határozatlan integrál kiszámítása parciális integrálással, majd ezután a határok behelyettesítése.

8.2 Példa. Néha szükség van a parciális integrálás többszöri elvégzésére. Tekintsük például az

$$
\int x^{2} e^{-\lambda x} d x
$$

integrált, ahol $\lambda>0$ adott paraméter. Használjuk az $f^{\prime}(x)=e^{-\lambda x}$, illetve $g(x)=x^{2}$ szereposztást, akkor

$$
\int x^{2} e^{-\lambda x} d x=-\frac{1}{\lambda} x^{2} e^{-\lambda x}+\frac{1}{\lambda} \int 2 x e^{-\lambda x} d x
$$

Az utóbbi integrált újabb parciális integrálással számíthatjuk ki.

Figyelem! Itt újra az $f^{\prime}(x)=e^{-\lambda x}$ illetve $g(x)=x$ szereposztást kell választanunk, ellenkező esetben egy használhatatlan azonossághoz jutunk!

$$
\int x^{2} e^{-\lambda x} d x=-\frac{1}{\lambda} x^{2} e^{-\lambda x}-\frac{2}{\lambda^{2}} x e^{-\lambda x}-\frac{2}{\lambda^{3}} e^{-\lambda x}+C
$$

8.3 Példa. Számítsuk ki az alábbi határozott integrált:

$$
\int_{0}^{\pi} e^{x} \sin x d x
$$

Használjuk az $f^{\prime}(x)=e^{x}$ és $g(x)=\sin x$ szereposztást, akkor kétszeri parciális integrálással:

$$
\begin{aligned}
\int_{0}^{\pi} e^{x} \sin x d x & =\left[e^{x} \sin x\right]_{0}^{\pi}-\int_{0}^{\pi} e^{x} \cos x d x \\
& =-\left[e^{x} \cos x\right]_{0}^{\pi}-\int_{0}^{\pi} e^{x} \sin x d x
\end{aligned}
$$

Fejezzük ki ebből az egyenlőségből a keresett integrált:

$$
2 \int_{0}^{\pi} e^{x} \sin x d x=-\left[e^{x} \cos x\right]_{0}^{\pi}
$$

azaz

$$
\int_{0}^{\pi} e^{x} \sin x d x=\frac{1}{2}\left(e^{\pi}+1\right)
$$




\subsection{Integrálás helyettesítéssel}

Az összetett függvény deriválási szabályából (láncszabály), annak integrálásával, adódik a következő formula:

$$
\int f(g(t)) g^{\prime}(t) d t=\int f(x) d x
$$

ahol $x=g(t)$ folytonosan differenciálható függvény egy adott intervallumon. Ezt a szabályt helyettesitéses integrálásnak nevezzük.

8.4 Példa. Határozzuk meg például az alábbi integrált:

$$
\int 5 t^{3} \sqrt{2+t^{4}} d t
$$

integrált. Vegyük észre, hogy az $x=g(t)=t^{4}$ helyettesítéssel az integrál a következő alakba írható:

$$
\int 5 t^{3} \sqrt{2+t^{4}} d t=\frac{5}{4} \int \sqrt{2+x} d x=\frac{5}{4} \cdot \frac{2}{3}(2+x)^{3 / 2}+C
$$

A visszehelyettesítést elvégezve:

$$
\int 5 t^{3} \sqrt{2+t^{4}} d t=\frac{5}{6}\left(2+t^{4}\right)^{3 / 2}+C
$$

8.5 Példa. Lássunk olyan példát, ahol a fordított eljárás a célravezetô:

$$
\int e^{x} \sqrt{1+e^{x}} d x
$$

Vezessük be az $x=\ln t$ helyettesítést, ekkor a formalizmus szerint $d x=\frac{1}{t} d t$, és így:

$$
\int e^{x} \sqrt{1+e^{x}} d x=\int t \sqrt{1+t} \frac{1}{t} d t=\frac{2}{3}(1+t)^{3 / 2}+C
$$

A $t=e^{x}$ visszahelyettesítéssel:

$$
\int e^{x} \sqrt{1+e^{x}} d x=\frac{2}{3}\left(1+e^{x}\right)^{3 / 2}+C
$$




\subsection{Helyettesítés határozott integráloknál}

Határozott integrálok kiszámításánál a visszahelyettesítésnél célravezetőbb és gyorsabb a határok megváltoztatása a helyettesítésnek megfelelően:

$$
\int_{a}^{b} f(g(t)) g^{\prime}(t) d t=\int_{g(a)}^{g(b)} f(x) d x
$$

8.6 Példa. Az alábbi példában az $x=\cos t, d x=-\sin t d t$ helyettesítést alkalmazzuk:

$$
\begin{aligned}
\int_{0}^{\pi / 2} \frac{\sin 2 t}{1+\cos ^{2} t} d t & =\int_{0}^{\pi / 2} \frac{2 \sin t \cos t}{1+\cos ^{2} t} d t \\
& =-\int_{1}^{0} \frac{2 x}{1+x^{2}} d x=\int_{0}^{1} \frac{2 x}{1+x^{2}} d x \\
& =\left[\ln \left(1+x^{2}\right)\right]_{0}^{1}=\ln 2
\end{aligned}
$$

8.7 Példa. Végül határozzuk meg az alábbi nevezetes integrált:

$$
\int_{0}^{1} \sqrt{1-x^{2}} d x
$$

Vezessük be az $x=\sin t$ helyettesítést, ekkor $d x=\cos t d t$ és (figyeljük meg a határok megváltoztatását!):

$$
\begin{aligned}
\int_{0}^{1} \sqrt{1-x^{2}} d x & =\int_{0}^{\pi / 2} \cos ^{2} t d t \\
& =\frac{1}{2} \int_{0}^{\pi / 2}(1+\cos 2 t) d t=\frac{1}{2}\left[t+\frac{\sin 2 t}{2}\right]_{0}^{\pi / 2}=\frac{\pi}{4}
\end{aligned}
$$

Vegyük észre, hogy itt éppen az origó középpontú, egységsugarú kör területének egynegyedét határoztuk meg helyettesítéses integrálással.

\subsection{Lineáris differenciálegyenlet}

Differenciálegyenleten egy olyan egyenletet értünk, amelyben az ismeretlen függvény, és annak deriváltja is szerepel. Számos mikro és makroökonómiai probléma vezet ilyen feladatra. Egy tipikus ilyen feladat a lineáris differenciálegyenlet. 
Legyenek $a$ és $b$ adott valós számok, és keressük azt az y ismeretlen differenciálható függvényt, amelyre

$$
\begin{aligned}
y^{\prime} & =a y+b \\
y(0) & =y_{0}
\end{aligned}
$$

ahol $y_{0}$ egy előre adott valós szám.

Itt az $y(0)=y_{0}$ egyenlőséget kezdeti feltételnek nevezzük. Azt mondjuk, hogy az $y$ differenciálható függvény a fenti feladat megoldása, ha bármely $t \in \mathbb{R}$ esetén $y^{\prime}(t)=$ $a y(t)+b$, továbbá $y(0)=y_{0}$. Kérdés, hogy hogyan állítható elő a feladat megoldása?

Tegyük fel tehát a továbbaikban, hogy y megoldás. Szorozzuk meg az egyenlet mindkét oldalát az $e^{-a t}$ kifejezéssel, akkor átrendezés után azt kapjuk, hogy

$$
y^{\prime}(t) e^{-a t}-a y(t) e^{-a t}=b e^{-a t}
$$

minden $t$ valós számra. Vegyük észre, hogy a bal oldalon éppen az $y(t) e^{-a t}$ szorzat deriváltja áll. Tehát mindkét oldalt a 0 ponttól $t$-ig integrálva (és az integrálási változót $t$-ről $s$-re cserélve)

$$
\int_{0}^{t}\left(y^{\prime}(s) e^{-a s}-a y(s) e^{-a s} d s=\left[y(s) e^{-a s}\right]_{0}^{t}=\int_{0}^{t} b e^{-a s} d s\right.
$$

A határok behelyettesítésével az adódik, hogy

$$
y(t) e^{-a t}-y(0)=\int_{0}^{t} b e^{-a s} d s .
$$

Átrendezve, és mindkét oldalt az $e^{a t}$ kifejezéssel szorozva az alábbi tételben fogalmazhatjuk meg az eredményünket.

8.8 Tétel. (Cauchy-formula) $A$ (8.1) feladat megoldása

$$
y(t)=e^{a t}\left(y_{0}+\int_{0}^{t} b e^{-a s}\right) d s
$$

a számegyenesen.

Ebből azt is láthatjuk, hogy ha az $y(0)=y_{0}$ kezdeti feltételt nem írnánk elő, akkor a 8.1 differenciálegyenletnek végtelen sok megoldása lenne.

8.9 Példa. Ha például az

$$
\begin{aligned}
y^{\prime} & =2 y+5 \\
y(0) & =3
\end{aligned}
$$

lineáris differenciálegyenlet megoldását keressük, akkor a Cauchy-formula szerint

$$
y(t)=e^{2 t}\left(3+\int_{0}^{t} 5 e^{-2 s} d s\right)=e^{2 t}\left(3-\frac{5}{2}\left[e^{-2 s}\right]_{0}^{t}\right)=\frac{11}{2} e^{2 t}-\frac{5}{2}
$$

minden $t \in \mathbb{R}$ mellett. 
Közvetlen behelyettesítéssel ellenőrizzük a megoldás helyességét!

\section{Otthoni tanuláshoz}

1. A Feladatgyứjtemény-1 I/9 és I/10 szakaszai kidolgozott példáinak feldolgozása.

2. Házi feladatok: az I/9 szakasz 9.3.4, 9.3.6, 9.3.8, 9.3.10, 9.3.13, 9.5.3, 9.5.6, valamint az I/10 szakasz 10.1.7, 10.1.9, 10.1.10 feladatai.

3. Tankönyv-1 11.1 és 11.2 szakaszai. 
AZ INTEGRÁLÁS KITERJESZTÉSE 



\subsection{Improprius integrálok}

Tegyük fel, hogy $f$ folytonos az $[a,+\infty)$ intervallumon. Ekkor bármely $b \geq a$ esetén létezik az $\int_{a}^{b} f(x) d x$ integrál.

9.1 Definíció. Azt mondjuk, hogy $f$ improprius értelemben integrálható az $[a, \infty)$ intervallumon, ha létezik a $\lim _{b \rightarrow \infty} \int_{a}^{b} f(x) d x$ határérték és véges. Az improprius integrál értékét ekkor az

$$
\int_{a}^{\infty} f(x) d x=\lim _{b \rightarrow \infty} \int_{a}^{b} f(x) d x
$$

egyenlőséggel definiáljuk. Ha a fenti határérték nem véges, vagy nem létezik, akkor azt mondjuk, hogy az improprius integrál nem létezik (vagy nem konvergens).

Analóg módon értelmezzük a

$$
\int_{-\infty}^{a} f(x) d x
$$

alakú improprius integrálokat is.

9.2 Példa. Vizsgáljuk meg az

$$
\int_{1}^{\infty} \frac{1}{x} d x
$$

integrált. A definíció alapján

$$
\int_{1}^{b} \frac{1}{x} d x=[\ln x]_{1}^{b}=\ln b
$$

tehát ez az improprius integrál nem létezik, hiszen $b \rightarrow \infty$ mellett a határérték nem véges.

Ugyanakkor az

$$
\int_{1}^{\infty} \frac{1}{x^{2}} d x
$$

integrál létezik, ugyanis újra a definíció alapján

$$
\lim _{b \rightarrow \infty} \int_{1}^{b} \frac{1}{x^{2}} d x=\lim _{b \rightarrow \infty}\left[-\frac{1}{x}\right]_{1}^{b}=1
$$

azaz az improprius integrál értéke 1.

A fenti gondolatmenet alapján könnyen látható, hogy az

$$
\int_{1}^{\infty} \frac{1}{x^{\alpha}} d x
$$

akkor és csak akkor létezik, ha $\alpha>1$, és ilyenkor az improprius integrál értéke

$$
\int_{1}^{\infty} \frac{1}{x^{\alpha}} d x=\frac{1}{\alpha-1}
$$

a felső határban ugyanis a határérték nulla. 
9.3 Példa. Tekintsük az alábbi példát (az exponenciális eloszlás sưrúségfüggvénye):

$$
\int_{0}^{\infty} \lambda e^{-\lambda x} d x
$$

ahol $\lambda>0$ adott konstans. Ekkor bármely $b>0$ mellett:

$$
\int_{0}^{b} \lambda e^{-\lambda x} d x=\left[-e^{-\lambda x}\right]_{0}^{b}=1-e^{-\lambda b}
$$

Tehát

$$
\int_{0}^{\infty} \lambda e^{-\lambda x} d x=\lim _{b \rightarrow \infty}\left(1-e^{-\lambda b}\right)=1
$$

bármely $\lambda>0$ konstans esetén.

\subsection{Improprius integrálok a számegyenesen}

9.4 Definíció. Azt mondjuk, hogy $f$ improprius értelemben integrálható a számegyenesen, ha a

$$
\int_{-\infty}^{0} f(x) d x \text { és } \int_{0}^{\infty} f(x) d x
$$

integrálok mindegyike létezik. Ekkor $\int_{-\infty}^{\infty} f(x) d x$ értéke e két integrál összege.

9.5 Példa. Például az

$$
\int_{-\infty}^{\infty} \frac{2 x}{1+x^{2}} d x
$$

integrál nem létezik, jóllehet bármely $b>0$ mellett

$$
\int_{-b}^{b} \frac{2 x}{1+x^{2}} d x=0
$$

hiszen az integrandus páratlan függvény. Azonban

$$
\int_{0}^{b} \frac{2 x}{1+x^{2}} d x=\ln \left(1+b^{2}\right)
$$

és ennek határértéke $b \rightarrow \infty$ esetén $+\infty$, ezért a definíció értelmében a fenti improprius integrál nem létezik. Nyilván ugyanígy nem létezik az integrál a $(-\infty, 0]$ intervallumon sem. 
9.6 Példa. Határozzuk meg az alábbi improprius integrált:

$$
I=\int_{0}^{\infty} x e^{-c x^{2}} d x
$$

ahol $c>0$ adott konstans. Itt bármely $b>0$ esetén

$$
\int_{0}^{b} x e^{-c x^{2}} d x=\left[-\frac{1}{2 c} e^{-c x^{2}}\right]_{0}^{b}
$$

Innen adódik, hogy $I=1 / 2 c$, és ennek alapján

$$
\int_{-\infty}^{\infty} x e^{-c x^{2}} d x=0
$$

hiszen az integrandus páratlan függvény.

9.7 Példa. (Gauss-féle integrál) Fontos szerepet játszik a valószínúségszámításban az

$$
I=\int_{-\infty}^{\infty} e^{-x^{2}} d x
$$

improprius integrál, amely a normális eloszlás sűrüségfüggvényével van kapcsolatban. Ennek kiszámítása elég komplikált eszközöket igényel, amelyeket itt nem részletezünk. Ennek oka az, hogy a primitív függvényt nem tudjuk elóállítani.

FIGYELEM! Ez nem azt jelenti, hogy nincs primitív függvény, hiszen az elôző fejezetünk értelmében létezik, mert az integrandus folytonos. A probléma az, hogy ezt a primitív függvényt elemi függvények segítségével nem lehet zárt alakban elóállítani.

Megmutatható, hogy

$$
\int_{0}^{\infty} e^{-x^{2}} d x=\frac{\sqrt{\pi}}{2}
$$

és innen az integrandus párossága folytán $I=\sqrt{\pi}$.

Egyszerú helyettesítéssel, ahol $x=t \sqrt{2}$, azt is láthatjuk, hogy

$$
\frac{1}{\sqrt{2 \pi}} \int_{-\infty}^{\infty} e^{-\frac{x^{2}}{2}} d x=1
$$

Ezt az egyenlőséget felhasználjuk a valószínúségszámításban. 


\subsection{Parciális integrálás improprius integrálban}

A következő példákban parciális integrálást használunk improprius integrálokban. A rövidség kedvéért a továbbiakban a $b \rightarrow+\infty$ határátmenet helyett a $+\infty$ felsô határt használjuk.

9.8 Példa. Határozzuk meg adott $\lambda$ pozitív konstans mellett az

$$
\int_{0}^{\infty} \lambda x e^{-\lambda x} d x
$$

improprius integrált. Az $f^{\prime}(x)=\lambda e^{-\lambda x}$ és $g(x)=x$ szereposztással (azért, hogy az $x$ szorzó eltûnjön), azt kapjuk, hogy

$$
\begin{aligned}
\int_{0}^{\infty} \lambda x e^{-\lambda x} d x & =\left[-x e^{-\lambda x}\right]_{0}^{\infty}-\int_{0}^{\infty}-e^{-\lambda x} d x \\
& =\left[\frac{e^{-\lambda x}}{\lambda}\right]_{0}^{\infty}=\frac{1}{\lambda}
\end{aligned}
$$

Ugyanis a kiintegrált rész nulla! Gondoljuk át: a L’Hôpital-szabály következménye.

9.9 Példa. Az előző példához hasonlóan határozzuk meg adott $\lambda$ pozitív konstans mellett az

$$
\int_{0}^{\infty} \lambda x^{2} e^{-\lambda x} d x
$$

improprius integrált. Az $f^{\prime}(x)=\lambda e^{-\lambda x}$ és $g(x)=x^{2}$ szereposztással (azért, hogy az $x^{2}$ szorzó fokszáma csökkenjen), két egymás utáni parciális integrálással (ugyanazon szereposztással) azt kapjuk, hogy

$$
\begin{aligned}
\int_{0}^{\infty} \lambda x^{2} e^{-\lambda x} d x & =\left[-x^{2} e^{-\lambda x}\right]_{0}^{\infty}-\int_{0}^{\infty}-2 x e^{-\lambda x} d x \\
& =\left[\frac{-2 x e^{-\lambda x}}{\lambda}\right]_{0}^{\infty}-\int_{0}^{\infty}-2 \frac{e^{-\lambda x}}{\lambda} d x \\
& =\left[-2 \frac{e^{-\lambda x}}{\lambda^{2}}\right]_{0}^{\infty}=\frac{2}{\lambda^{2}}
\end{aligned}
$$

Ebben a példában két egymás utáni parciális integrálásra volt szükségünk, és az előző példához hasonlóan a kiintegrált részek nullák a L’Hôpital-szabály miatt. 
9.10 Példa. Parciális integrálással keressük meg az

$$
\int_{-\infty}^{\infty} x^{2} e^{-x^{2} / 2} d x
$$

improprius integrál értékét. A tényezők szerepét ügyesen kiosztva a következőt kapjuk:

$$
\int_{-\infty}^{\infty}(-x) \cdot\left(-x e^{-x^{2} / 2}\right) d x=\left[-x e^{-x^{2} / 2}\right]_{-\infty}^{\infty}+\int_{-\infty}^{\infty} e^{-x^{2} / 2} d x=\sqrt{2 \pi}
$$

a 9.2 formula értelmében. Vegyük ugyanis észre, hogy a kiintegrált tagban mindkét határérték zérus a L'Hôpital-szabály miatt. Következésképpen

$$
\int_{-\infty}^{\infty} x^{2} e^{-x^{2} / 2} d x=\sqrt{2 \pi}
$$

\subsection{Harmonikus sorok vizsgálata}

A korábbiakban láttuk, hogy valamely $\alpha>0$ valós kitevő mellett a

$$
\sum_{k=1}^{\infty} \frac{1}{k^{\alpha}}
$$

végtelen sor divergens, ha $\alpha \leq 1$, illetve konvergens, ha $\alpha \geq 2$. Nem tudtunk azonban választ adni az $1<\alpha<2$ esetben. Erre most megoldást tudunk adni az improprius integrálok segítségével. Valóban, tekintsük a fenti sor $n$-ik részletösszegét

$$
S_{n}=\sum_{k=1}^{n} \frac{1}{k^{\alpha}}
$$

és rajzoljuk fel az

$$
f(x)=\frac{1}{x^{\alpha}}
$$

függvény grafikonját a pozitív félegyenesen. Vegyük fel a függvényértékeket az $1, \ldots, n$ egész helyeken, akkor a grafikont vizsgálva könnyen látható, hogy

$$
S_{n}<1+\int_{1}^{n} \frac{1}{x^{\alpha}} d x
$$

hiszen az $f$ függvény szigorúan monoton fogyó.

KÉSZÍTSÜNK ÁBRÁT! 
Másrészt az $f$ függvény pozitív és $\alpha>1$ esetén az improprius integrálja véges az $[1, \infty)$ intervallumon, lásd a 9.1 egyenlőséget. Tehát

$$
S_{n}<1+\int_{1}^{n} \frac{1}{x^{\alpha}} d x<1+\int_{1}^{\infty} \frac{1}{x^{\alpha}} d x=1+\frac{1}{\alpha-1}=\frac{\alpha}{\alpha-1} .
$$

Mivel $S_{n}$ szigorúan monoton növő, innen adódik, hogy korlátos is, azaz konvergens. Ezt az eredményünket az alábbi állításban fogalmazzuk meg.

9.11 Állítás. A 9.4 alatti végtelen sor akkor és csak akkor konvergens, ha $\alpha>1$, és ebben az esetben

$$
\sum_{k=1}^{\infty} \frac{1}{k^{\alpha}}<\frac{\alpha}{\alpha-1}
$$

\section{Otthoni tanuláshoz}

1. A Feladatgyújtemény-1 I/10 szakasza kidolgozott példáinak feldolgozása.

2. Házi feladatok: a Feladatgyújtemény-1 I/10 szakaszának 10.2.10, 10.2.13, 10.2.14, 10.2.16, 1.6.2, 1.8.6, 1.8.9 feladatai.

3. Tankönyv-1 11.3 és 11.4 szakaszai. 
10.

HATVÁNYSOROK 



\subsection{Hatványsorok összege}

Ha $-1<x<1$ valós szám, akkor a geometriai sorokról láttuk, hogy a sor konvergens, és

$$
\frac{1}{1-x}=\sum_{k=0}^{\infty} x^{k} .
$$

Számos alkalmazásban fontos kérdés, hogy valamely $f$ függvény megadható-e

$$
f(x)=\sum_{k=0}^{\infty} a_{k} x^{k}
$$

alakban alkalmas $a_{k}$ együtthatókkal. Ilyenkor azt mondjuk, hogy $f$ hatványsorba fejthetô.

10.1 Definíció. A 10.1 egyenlőség jobb oldalán álló sort hatványsornak nevezzük, a bal oldalon álló $f$ függvény a hatványsor összegfüggvénye.

Két kérdést vizsgálunk a fejezet hátralévő részében.

1. Milyen $x$ értékekre konvergens egy hatványsor, és ott mi az $f$ összegfüggvény.

2. Fordítva, egy adott $f$ függvény esetén hogyan található meg az a hatványsor, amelynek $f$ az összegfüggvénye.

Világos, hogy bármely hatványsor $x=0$ esetén konvergens, és az összege $a_{0}$. Azon $x$ értékek halmazát, amelyekre a hatványsor konvergens, konvergencia-halmaznak nevezzük.

\subsection{A konvergencia-sugár}

Egy hatványsor konvergencia-halmaza mindig egy origóra szimmetrikus intervallum, ezt fogalmazza meg a következő tételünk.

10.2 Tétel. (Cauchy-Hadamard-tétel) $A(10.1$ hatványsorhoz található olyan $R$ nemnegatív szám (lehet $R=0$ vagy végtelen is), hogy a sor konvergens $a-R<x<R$ nyílt intervallumban, és divergens a $[-R, R]$ zárt intervallumon kívül. 
Bizonyítás. Csak arra az esetre szorítkozunk, amikor létezik a

$$
\lim _{k \rightarrow \infty}\left|\frac{a_{k+1}}{a_{k}}\right|=r
$$

határérték. Vezessük be a következő jelölést:

$$
R= \begin{cases}1 / r & \text { ha } 0<r<+\infty \\ +\infty & \text { ha } r=0 \\ 0 & \text { ha } r=\infty\end{cases}
$$

A Hányados-kritérium alapján a hatványsor konvergens, ha

$$
\lim _{k \rightarrow \infty}\left|\frac{a_{k+1} x^{k+1}}{a_{k} x^{k}}\right|<1
$$

ez a fenti jelölésünkkel éppen azt jelenti, hogy $|x|<R$.

Teljesen hasonló módon láthatjuk be a hányados-kritérium felhasználásával, hogy a hatványsor divergens, ha $|x|>R$.

10.3 Definíció. A fent bevezetett $R$ számot a hatványsor konvergencia-sugarának nevezzük.

10.4 Példa. Tekintsük például a

$$
\sum_{k=0}^{\infty} \frac{x^{k}}{k !}
$$

hatványsort, itt

$$
\lim _{k \rightarrow \infty} \frac{a_{k+1}}{a_{k}}=\lim _{k \rightarrow \infty} \frac{k !}{(k+1) !}=\lim _{k \rightarrow \infty} \frac{1}{k+1}=0
$$

ezért itt $R=\infty$, azaz a hatványsor az egész számegyenesen konvergens.

Egyik másik példaként vizsgáljuk meg a

$$
\sum_{k=1}^{\infty} \frac{x^{k}}{k}
$$

hatványsort. Világos, hogy ekkor

$$
\lim _{k \rightarrow \infty} \frac{a_{k+1}}{a_{k}}=\lim _{k \rightarrow \infty} \frac{k}{k+1}=1
$$

tehát $R=1$, ezért a hatványsor konvergens a $(-1,1)$ nyílt intervallumban, és divergens a $[-1,1]$ zárt intervallumon kívül. Másrészt látható, hogy $x=1$ esetén a divergens harmonikus sorhoz jutunk, továbbá $x=-1$ esetén pedig a konvergens váltakozó előjelú sorhoz, lásd a 2.10 Példát. Tehát a

$$
[-1,1)
$$

balról zárt, jobbról nyílt intervallum a sor konvergencia-halmaza. 


\subsection{Hatványsor differenciálhatósága}

Tekintsünk egy hatványsort, amelynek $R>0$ a konvergencia-sugara, és $f$ az összegfüggvénye, azaz

$$
\sum_{k=0}^{\infty} a_{k} x^{k}=f(x)
$$

minden $-R<x<R$ mellett.

10.5 Tétel. A hatványsor f összegfüggvénye differenciálható, mégpedig

$$
f^{\prime}(x)=\sum_{k=1}^{\infty} k a_{k} x^{k-1}
$$

$a(-R, R)$ nyílt intervallumban.

A tétel bizonyítását nem végezzük el, csak megjegyezzük, hogy az úgynevezett "egyenletes konvergencia" fogalmán múlik. Néhány további megjegyzést könnyen kiolvashatunk a tétel állításából.

- A derivált a hatványsor tagonkénti deriválásával állítható elő. Ez nem nyilvánvaló, hiszen a tagonkénti deriválás szabályát csak véges összegre igazoltuk, végtelen összegre általában nem érvényes. KERESSÜNK PÉLDÁT!

- Vegyük észre, hogy a tagonkénti deriválással előállított hatványsor konvergencia-sugara továbbra is $R$. ELLENŐRIZZÜK!

- Mivel $f^{\prime}$ is egy hatványsor összege ugyanazon intervallumon, ezért a tétel többszöri alkalmazásával láthatjuk, hogy ilyenkor $f$ akárhányszor differenciálható a $(-R, R)$ nyílt intervallumban.

10.6 Példa. Tekintsük például $-1<x<1$ esetén a

$$
\sum_{k=0}^{\infty} x^{k}=\frac{1}{1-x}
$$

hatványsort. Vegyük észre, hogy a sor első tagja 1, amelynek deriváltja nulla. Igy a fenti tételünk szerint

$$
\sum_{k=1}^{\infty} k x^{k-1}=\frac{1}{(1-x)^{2}}
$$

minden $-1<x<1$ esetén. 
10.7 Példa. Keressük meg azt az $f$ függvényt, amelyet a következő sor állít elő

$$
f(x)=\sum_{k=1}^{\infty}(-1)^{k-1} \frac{x^{k}}{k}
$$

Egyszerú számolással adódik, hogy a konvergencia-sugár $R=1$. Ekkor egyrészt $f(0)=$ 0, másrészt a hatványsor differenciálhatósága alapján

$$
f^{\prime}(x)=\sum_{k=1}^{\infty} k \frac{(-x)^{k-1}}{k}=\sum_{k=1}^{\infty}(-x)^{k-1}=\frac{1}{1+x}
$$

minden $-1<x<1$ esetén. Innen

$$
f(x)=f(0)+\int_{0}^{x} \frac{1}{1+t} d t=[\ln (1+t)]_{0}^{x}=\ln (1+x)
$$

a $(-1,1)$ nyílt intervallumban. Sőt, ez utóbbi sor a 2.10 Példa szerint az $x=1$ helyen is konvergens, ahonnan a nevezetes

$$
1-\frac{1}{2}+\frac{1}{3}-\frac{1}{4}+\frac{1}{5}-\ldots=\ln 2
$$

azonosság adódik.

\subsection{Az együtthatók meghatározása}

Felmerül a kérdés, hogy egy adott $f$ függvény előállítható-e valamely hatványsor összegeként egy adott intervallumban. A differenciálhatósági tétel szerint ilyenkor $f$ szükségképpen akárhányszor differenciálható. Vajon hogyan kaphatjuk meg az $a_{k}$ együtthatókat?

A differenciálhatósági tétel alapján a (10.1) alatti $f$ függvényhez tartozó $a_{k}$ együtthatókat meghatározhatjuk az $f$ deriváltjai segítségével. Vegyük észre, hogy

$$
f(0)=a_{0}, \quad f^{\prime}(0)=a_{1}, \quad f^{\prime \prime}(0)=2 a_{2}, \quad \ldots
$$

és általában tetszőleges $k$ indexre

$$
f^{(k)}(0)=k ! \cdot a_{k}
$$

Ha ezeket a kifejezéseket beírjuk az $a_{k}$ együtthatók helyére, akkor az

$$
f(x)=\sum_{k=0}^{\infty} \frac{f^{(k)}(0)}{k !} x^{k}
$$

előállításhoz jutunk. Ezt az alakot az $f$ függvény Taylor-sorának nevezzük. 


\subsection{Az exponenciális függvény hatványsora}

Tekintsük ebben a szakaszban az $e^{x}$ exponenciális függvényt. Ha ez a függvény valamely hatványsor összegeként áll elő, akkor a sor együtthatói csak az

$$
a_{k}=\frac{1}{k !}
$$

kifejezések lehetnek, hiszen a függvény akárhányadik deriváltja is $e^{x}$, amely az $x=0$ helyen az 1 értéket veszi fel. Ez azt mutatja, hogy az $e^{x}$ függvényhez rendelt hatványsor

$$
\sum_{k=0}^{\infty} \frac{x^{k}}{k !}
$$

amely a korábbi példánk szerint az egész számegyenesen konvergens.

Csak az a probléma, és ezért nem írtunk egyenlőséget, mert egyelőre nem világos, hogy az $e^{x}$ függvény valóban előáll-e hatványsor összegfüggvényeként.

Ennek megválaszolásához tekintsük az

$$
f(x)=\sum_{k=0}^{\infty} \frac{x^{k}}{k !}
$$

egyelőre ismeretlen függvényt a számegyenesen. Világos, hogy egyrészt $f(0)=1$, másrészt a differenciálhatósági tételünk szerint

$$
f^{\prime}(x)=\sum_{k=1}^{\infty} k \frac{x^{k-1}}{k !}=\sum_{k=1}^{\infty} \frac{x^{k-1}}{(k-1) !}=f(x)
$$

minden $-\infty<x<\infty$ esetén. Ez egy egyszerú lineáris differenciálegyenlet az ismeretlen $f$ függvényre, amelynek megoldása

$$
f(x)=e^{x}
$$

az egész számegyenesen. Innen adódik a nevezetes azonosság

$$
e=1+\frac{1}{1 !}+\frac{1}{2 !}+\ldots+\frac{1}{n !}+\ldots
$$

az $x=1$ behelyettesítésével.

\section{Otthoni tanuláshoz}

1. A Feladatgyưjtemény-1 I/2 és I/8 szakaszai kidolgozott példáinak feldolgozása.

2. Házi feladatok: az I/2 szakasz 2.1.7, 2.1.9, 2.1.11, 2.2.3, 2.2.9, valamint az I/8 szakasz 8.1.8, 8.2.4, 8.2.5 és 8.3.3 feladatai.

3. Tankönyv-1 6.5 szakasza. 



\section{1.}

\section{KÉTVÁLTOZÓS FÜGGVÉNYEK DERIVÁLÁSA}





\subsection{Parciális deriváltak}

Tekintsünk egy kétváltozós $f: \mathbb{R}^{2} \rightarrow \mathbb{R}$ függvényt. Rögzítsünk le egy $y=b$ pontot és vizsgáljuk az így keletkező

$$
x \rightarrow f(x, b)
$$

egyváltozós függvényt. Tegyük fel, hogy ez a függvény differenciálható valamely $a$ helyen és határozzuk meg a deriváltját.

11.1 Definíció. A fenti deriváltat az $f x$ változó szerinti parciális deriváltjának nevezzük az $(a, b)$ helyen. Jelölése:

$$
\frac{\partial f}{\partial x}(a, b)=f_{1}^{\prime}(a, b)
$$

Néha használatos az $f_{x}^{\prime}(a, b)$ jelölés is.

11.2 Példa. Tekintsük például $f(x, y)=(x+2 y) e^{x+3 y-1}$ függvényt és határozzuk meg az $x$ változó szerinti parciális deriváltat az $(1,1)$ pontban.

Ekkor $f(x, 1)=(x+2) e^{x+2}$, amelynek deriváltja az $x$ helyen

$$
f_{1}^{\prime}(x, 1)=e^{x+2}+(x+2) e^{x+2}=(x+3) e^{x+2}
$$

Ennek az $x=1$ helyen felvett értéke $f_{1}^{\prime}(1,1)=4 e^{3}$.

11.3 Példa. Elvileg azt is megtehetnénk, hogy formálisan meghatároznánk az $f$ függvény $x$ változó szerinti parciális deriváltját tetszőleges fix $y$ mellett, majd ezt követően behelyettesítenénk az $x=a$ és $y=b$ értékeket. Ez azonban nem mindig célszerú, amint ezt a következő példán láthatjuk. Legyen

$$
f(x, y)=\sqrt{x^{2}+y^{2}+5} \cdot e^{-2 x+y} \cdot \cos (y+\pi / 2)
$$

és határozzuk meg az $x$-szerinti parciális deriváltat az $(1,0)$ pontban. Ekkor a deriválás elvégzése hosszadalmas lenne. Ha azonban a definíció szerint járunk el, akkor láthatjuk, hogy

$$
f(x, 0)=0
$$

minden $x$ értékre, ezért $f_{1}^{\prime}(1,0)=0$.

$\mathrm{Az}$

$$
x \rightarrow \frac{\partial f}{\partial x}(x), \quad x \in \mathbb{R}
$$

hozzárendelést az $f$ függvény $x$ változó szerinti parciális deriváltfüggvényének nevezzük. 


\section{2. Érintősíkok}

A parciális deriváltaknak (az egyváltozós esethez hasonlóan) geometriai értelmezés is adható. Tekintsünk egy $f: \mathbb{R}^{2} \rightarrow \mathbb{R}$ kétváltozós függvényt. Ennek grafikonja egy felületet ad a háromdimenziós térben. Válasszuk ki e felületnek a

$$
P(a, b, f(a, b))
$$

pontját. Ha ezt a felületet metszi a $P$ ponton átmenő $y=b$ sík, akkor egy görbéhez jutunk. E görbe érintőjének meredeksége a $P$ pontban az $f_{1}^{\prime}(a, b)$ parciális derivált. Teljesen hasonló interpretációt adhatunk az $x=a$ síkban fekvő érintő meredekségére is. A két érintő által meghatározott sík normálvektora tehát

$$
v=\left[f_{1}^{\prime}(a, b), f_{2}^{\prime}(a, b),-1\right]
$$

azaz a $c=f(a, b)$ jelöléssel a sík egyenlete

$$
f_{1}^{\prime}(a, b)(x-a)+f_{2}^{\prime}(a, b)(y-b)-(z-c)=0 .
$$

Ezt a síkot a felület $P$ pontbeli érintősíkjának nevezzük.

11.4 Példa. Adjuk meg az $p$ paraméter értékét úgy, hogy az

$$
f(x, y)=p x \sqrt{x^{2}+y^{2}+1}-7
$$

függvény $a=2, b=2, c=f(2,2)$ pontnál húzott érintősíkja átmegy a $Q(2,-1,6)$ ponton.

Világos, hogy $f(2,2)=3 p-7$, azaz a $P(2,2,3 p-7)$ ponthoz húzott érintősík egyenletét keressük. Mivel

$$
\frac{\partial f}{\partial x}(2,2)=\frac{10}{3} p \quad \text { és } \quad \frac{\partial f}{\partial y}(2,2)=\frac{2}{3} p
$$

azért az érintősík egyenlete a $P$ pontban

$$
\frac{10}{3} p(x-2)+\frac{2}{3} p(y-2)-(z-3 p+7)=0 .
$$

Ha az érintôsík átmegy a $Q$ ponton, akkor annak koordinátái kielégítik a sík egyenletét. Ez a következő egyenletet adja az ismeretlen $p$ paraméterre:

$$
-\frac{2}{3} 3 p=13-3 p
$$

Ennek egyetlen megoldása $p=13$. 


\subsection{A láncszabály}

Tekintsük most az $f: \mathbb{R}^{2} \rightarrow \mathbb{R}$ valamint a $g: \mathbb{R} \rightarrow \mathbb{R}^{2}$ függvényeket, ahol minden $t \in \mathbb{R}$ esetén

$$
g(t)=\left(g_{1}(t), g_{2}(t)\right)
$$

Tegyük fel, hogy $g$ értékkészlete az $f$ értelmezési tartományában fekszik. Ekkor vizsgálhatjuk az

$$
f \circ g: \mathbb{R} \rightarrow \mathbb{R}
$$

kompozíció függvény differenciálhatóságát.

11.5 Tétel. (Láncszabály) $\mathrm{Ha}_{1} \mathrm{~g}_{1}$ é $g_{2}$ differenciálhatóak a t pontban és $f$ parciális deriváltfüggvényei folytonosak a $g(t)$ pontban, akkor $f \circ g$ is differenciálható a $t$ pontban, és

$$
(f \circ g)^{\prime}(t)=\frac{\partial f}{\partial x}(g(t)) g_{1}^{\prime}(t)+\frac{\partial f}{\partial y}(g(t)) g_{2}^{\prime}(t)
$$

Tételünk állítása az egyváltozós láncszabályhoz (lásd a 4. fejezetben) technikailag kicsit bonyolultabban, de teljesen hasonló elven igazolható.

11.6 Példa. Legyen például $f(x, y)=x^{2}-x y+y^{2}$, továbbá

$$
x=g_{1}(t)=\cos t \quad y=g_{2}(t)=\sin t
$$

és tekintsük az $F(t)=(f \circ g)(t)$ összetett függvényt. Ekkor a láncszabály szerint

$$
\begin{aligned}
F^{\prime}(t) & =(f \circ g)^{\prime}(t)=\frac{\partial f}{\partial x}(g(t)) g_{1}^{\prime}(t)+\frac{\partial f}{\partial y}(g(t)) g_{2}^{\prime}(t) \\
& =(2 \cos t-\sin t)(-\sin t)+(-\cos t+2 \sin t) \cos t=\sin ^{2} t-\cos ^{2} t
\end{aligned}
$$

minden $t \in \mathbb{R}$ esetén.

11.7 Példa. Tekintsünk egy $f: \mathbb{R}^{2} \rightarrow \mathbb{R}$ függvényt, amelynek a parciális deriváltjai léteznek és folytonosak, és legyen $v=\left(v_{1}, v_{2}\right) \in \mathbb{R}^{2}$ adott vektor. Ekkor a $P(a, b) \in \mathbb{R}^{2}$ ponton átmenő, $v$ irányvektorú egyenes egyenlete

$$
g(t)=(a, b)+t v=\left(a+t v_{1}, b+t v_{2}\right) .
$$

Ezekkel a jelöléssekkel egyrészt $g_{1}^{\prime}(t)=v_{1}, g_{2}^{\prime}(t)=v_{2}$, másrészt az

$$
F(t)=f(a+t v)
$$


egyváltozós függvény deriváltja a láncszabály szerint:

$$
F^{\prime}(t)=\frac{\partial f}{\partial x}((a, b)+t v) v_{1}+\frac{\partial f}{\partial y}((a, b)+t v) v_{2}
$$

illetve speciálisan $t=0$ esetén

$$
F^{\prime}(0)=\frac{\partial f}{\partial x}(a, b) v_{1}+\frac{\partial f}{\partial y}(a, b) v_{2}
$$

FIGYELEM! Ellenőrizzük ezt az eredményt a $g$ függvény közvetlen behelyettesítésével, majd az így kapott $F=f \circ g$ függvény deriválásával is!

\subsection{Lokális szélsőérték}

A továbbiakban a kétdimenziós tér valamely $v=(x, y)$ vektorának abszolút értékét (az origótól mért távolságát) a következő módon értelmezzük:

$$
\|v\|=\left(x^{2}+y^{2}\right)^{1 / 2}
$$

amelyet a $v$ vektor normájának nevezünk.

11.8 Definíció. Az $\mathbb{R}^{2}$ tér origó középpontú egységsugarú környezetén a

$$
B=\left\{v \in \mathbb{R}^{2}:\|v\| \leq 1\right\}
$$

halmazt értjük. Világos, hogy valamely $(a, b) \in \mathbb{R}^{n}$ pont körüli $r>0$ sugarú környezete az

$$
(a, b)+r B=\left\{v \in \mathbb{R}^{2}:\|v-(a, b)\| \leq r\right\}
$$

formulával adható meg.

Tekintsünk egy $f: \mathbb{R}^{2} \rightarrow \mathbb{R}$ függvényt. Azt mondjuk, hogy az értelmezési tartomány valamely $P(a, b)$ pontja az $f$ lokális minimumhelye, ha található olyan $\varepsilon>0$, hogy

$$
f(x, y) \geq f(a, b)
$$

az értelmezési tartomány mindazon $(x, y)$ pontjaiban, amelyekre $(x, y) \in(a, b)+\varepsilon B$, azaz $\|(x, y)-(a, b)\| \leq \varepsilon$.

Hasonlóan értelmezzük a lokális maximum fogalmát, és értelemszerúen fogalmazhatjuk meg a globális minimum és maximum definícióját is.

Tegyük fel a továbbiakban, hogy az $f: \mathbb{R}^{2} \rightarrow \mathbb{R}$ függvény parciális deriváltjai léteznek és folytonosak. 


\subsection{Elsőrendű szükséges feltétel}

11.9 Tétel. Ha az $(a, b) \in \mathbb{R}^{2}$ pont az $f$ lokális minimumhelye, akkor $f_{1}^{\prime}(a, b)=0$ és $f_{2}^{\prime}(a, b)=0$.

Bizonyítás. Legyen ugyanis $v \in \mathbb{R}^{n}$ egy tetszőleges nem nulla vektor, és tekintsük az alábbi függvényt

$$
F(t)=f((a, b)+t v) .
$$

A lokális minimum definíciója alapján az $F$ függvénynek lokális minimumhelye van a $t=0$ pontban, másrészt a láncszabály szerint $F$ differenciálható is, éspedig

$$
F^{\prime}(t)=\frac{\partial f}{\partial x}((a, b)+t v) v_{1}+\frac{\partial f}{\partial y}((a, b)+t v) v_{2}
$$

A lokális minimumhely miatt $F^{\prime}(0)=0$ bármely $v$ vektor mellett, azaz

$$
\frac{\partial f}{\partial x}((a, b)) v_{1}+\frac{\partial f}{\partial y}((a, b)) v_{2}=0
$$

bármely $v_{1}$ és $v_{2}$ valós számokra. Ez csak úgy lehetséges, ha

$$
\frac{\partial f}{\partial x}((a, b))=0 \quad \text { és } \quad \frac{\partial f}{\partial y}((a, b))=0
$$

amit igazolni akartunk.

A fenti tétel szerint a parciális deriváltakra felírt egyenletrendszer megoldásai között kereshetjük a függvény szélsőértékhelyeit. Ez az egyenletrendszer azonban (az egyváltozós esethez hasonlóan) csak szükséges feltételt fogalmaz meg. Például az

$$
f(x, y)=x^{3} y^{2}
$$

függvény esetében az $f_{1}^{\prime}(x, y)=f_{2}^{\prime}(x, y)=0$ egyenletrendszer egyik megoldása $(x, y)=$ $(0,0)$. Ekkor

$$
f(0,0)=0
$$

de ez nem lehet szélsőérték, hiszen $f$ az origó körüli bármilyen sugarú gömb belsejében felvesz pozitív és negatív értékeket is.

11.10 Példa. Tekintsük az

$$
f(x, y)=\frac{1}{x}+\frac{1}{y}+\frac{x y}{8}
$$


függvényt a síkon, ahol $x \neq 0$ és $y \neq 0$, és keressük a szélsőértékeket. A fenti tételünk értelmében szélsőérték csak a parciális deriváltak zérushelyeinél lehet. Keressük meg tehát a

$$
\begin{aligned}
& \frac{\partial f}{\partial x}=-\frac{1}{x^{2}}+\frac{y}{8}=0 \\
& \frac{\partial f}{\partial y}=-\frac{1}{y^{2}}+\frac{x}{8}=0
\end{aligned}
$$

egyenletrendszer megoldásait. Ennek az egyenletrendszernek az egyetlen megoldása

$$
x=2 \text { és } y=2 \text {, }
$$

és az $f$ függvénynek csak ebben a pontban lehet szélsőértéke.

Azt, hogy egy ilyen kritikus pont valóban szélsőérték-e, a Lineáris Algebra tárgyban kifejtett eszközökkel tudjuk majd megvizsgálni (lásd a harmadik félévben). Megjegyezzük, hogy jelen esetben a $P(2,2)$ pont a függvény minimumhelye.

\section{Otthoni tanuláshoz}

1. A Feladatgyújtemény-1 III/1 szakasza kidolgozott példáinak feldolgozása.

2. Házi feladatok: a III/1 szakasz 1.1.4, 1.1.5, 1.1.6, 1.1.7, 1.4.3, 1.4.4, 1.4.5, 1.5.3, 1.5.4, 1.6.3, 1.6.5 feladatai.

3. Tankönyv-1 15.3, 15.4, 15.6, 16.1 és 16.2 szakaszai. 
12.

FELTÉTELES SZÉLSŐÉRTÉK 



\subsection{Implicit függvények}

A mikróökonómiában gyakran felmerülő probléma, hogy valamely

$$
F(x, y)=0
$$

egyenletből az $y$ változó mikor fejezhető ki egyértelmúen az $x$ függvényeként. Más szavakkal: található-e egyetlen olyan $y=g(x)$ függvény, amelyre fennáll az

$$
F(x, g(x))=0
$$

azonosság minden $x$ pontban.

Ilyen függvény nem feltétlenül létezik. Például az

$$
F(x, y)=x^{2}+y^{2}-1=0
$$

egyenlet esetében (az egységsugarú kör egyenlete) az y nem fejezhető ki egyértelmúen az $x$ függvényeként. Geometriailag ez azt jelenti, hogy az $F(x, y)=0$ egyenletet kielégítő pontok a síkon nem alkothatják egy függvény grafikonját. Ennek az az oka, hogy a fenti görbét az $y$-tengellyel párhuzamos egyenesek két helyen is metszik.

Előfordulhat az is, hogy az implicit egyenletből az y változó algebrai átalakításokkal nem fejezhető ki. Például ilyen az

$$
F(x, y)=e^{x+y}-2 \cos y+1=0
$$

egyenlet. Látható, hogy az egyenletet az $(x, y)=(0,0)$ pont kielégíti, de az y változót nem tudjuk kifejezni.

Felmerül az is, hogy ha $F$ differenciálható függvény, akkor mikor fejezhetô ki a fenti egyenletből $y$ az $x$ differenciálható függvényeként. Erre ad választ az alábbi tétel.

12.1 Tétel. (Implicitfüggvény-tétel) Tegyük fel, hogy valamely $\left(x_{0}, y_{0}\right)$ pontban

$$
F\left(x_{0}, y_{0}\right)=0
$$

továbbá $F$ parciális deriváltjai folytonosak e pont egy környezetében, és

$$
F_{2}^{\prime}\left(x_{0}, y_{0}\right) \neq 0
$$

Akkor létezik egyetlen olyan folytonosan differenciálható g függvény az $x_{0}$ pont egy környezetében, amelyre

- $g\left(x_{0}\right)=y_{0}$

- $F(x, g(x))=0$ minden $x$ pontban

- $g^{\prime}(x)=-F_{1}^{\prime}(x, g(x)) / F_{2}^{\prime}(x, g(x))$ 
Felhívjuk a figyelmet arra, hogy a parciális deriváltak folytonosságából adódik, hogy $F_{2}^{\prime}(x, g(x)) \neq 0$ az $x_{0}$ egy kis környezetében.

Tételünk geometriailag azt fejezi ki, hogy ha az $F(x, y)=0$ egyenletû́ síkbeli görbéhez az $\left(x_{0}, y_{0}\right)$ pontban húzott érintő nem párhuzamos az $y$-tengellyel, akkor e pont egy környezetében (lokálisan) az y kifejezhetô az $x$ differenciálható függvényeként.

12.2 Példa. Tekintsük például az

$$
F(x, y)=e^{x+y}+x+y-1=0
$$

implicit egyenletet. Ezt az egyenletet a $(0,0)$ pont kielégíti. Másrészt ebben a pontban

$$
F_{2}^{\prime}(0,0)=2
$$

Tehát $F$ kielégíti az Implicitfüggvény-tétel feltételeit, ezért az egyenlet egyértelmúen meghatároz egy $y=g(x)$ differenciálható függvényt. A tétel szerint

$$
\begin{aligned}
g^{\prime}(x) & =-F_{1}^{\prime}(x, g(x)) / F_{2}^{\prime}(x, g(x)) \\
& =-\frac{1}{e^{x+g(x)}+1} \cdot\left(e^{x+g(x)}+1\right)=-1
\end{aligned}
$$

minden $x$ pontban. Mivel $g(0)=0$, ez azt jelenti, hogy

$$
g(x)=-x
$$

és ez az egyetlen megoldás.

12.3 Példa. Tekintsük a fentebb említett

$$
F(x, y)=e^{x+y}-2 \cos y+1=0
$$

implicit egyenletet. Ezt az egyenletet a $(0,0)$ pont kielégíti. Másrészt ebben a pontban

$$
F_{2}^{\prime}(0,0)=1
$$

ezért fennállnak az Implicitfüggvény-tétel feltételei. Tehát ez az egyenlet egyértelmúen meghatároz egy $g$ differenciálható függvényt, bár ezt a függvényt az egyenletből algebrai átalakításokkal nem tudjuk előállítani. 


\subsection{Feltételes szélsőérték}

Tekintsük az $f$ és $F$ egyaránt $\mathbb{R}^{2} \rightarrow \mathbb{R}$ függvényeket, és tegyük fel a továbbiakban hogy léteznek és folytonosak a parciális deriváltjaik. Feltételes szélsőérték-feladaton az

$$
\begin{aligned}
& f(x, y) \rightarrow \min \\
& F(x, y)=c
\end{aligned}
$$

ahol $c$ adott valós állandó. Más szavakkal az $f$ minimumát (vagy máskor maximumát) keressük a

$$
H=\left\{(x, y) \in \mathbb{R}^{2}: F(x, y)=c\right\}
$$

halmazon.

12.4 Definíció. Azt mondjuk, hogy az $\left(x_{0}, y_{0}\right) \in H$ pont a 12.1 feltételes szélsőértékfeladat megoldása, ha

$$
f\left(x_{0}, y_{0}\right) \leq f(x, y)
$$

minden $(x, y) \in H$ esetén. Analóg definíció érvényes maximum esetére.

12.5 Példa. Az alábbi példánk azt illusztrálja, hogy a korábbi szélsőértékre vonatkozó szükséges feltételeink az ilyen feladatokban nem múködnek. Tekintsük például az

$$
f(x, y)=x^{2}+2 y, \quad F(x, y)=x+y \quad \text { azaz } \quad c=0
$$

feladatot. Ekkor az $x+y=0$ feltételből $y=-x$, és így $f(x, y)=x^{2}-2 x$. Ennek az $x=1$ pontban van minimuma, és itt a feltétel szerint $y=-1$, azaz a feltételes minimum az

$$
\left(x_{0}, y_{0}\right)=(1,-1)
$$

pontban található. Ebben a pontban azonban a

$$
\frac{\partial f}{\partial x}=0, \quad \frac{\partial f}{\partial y}=0
$$

egyenlőségek egyike sem teljesül.

A fenti példában láthatjuk, hogy a feltételes szélsőérték-feladat feltétel nélkülivé alakítható át, ha az $F(x, y)=c$ feltételből az y változó kifejezhető. Nehezebb feladatoknál ezt azonban algebrai átalakításokkal nem tudjuk elvégezni. 


\subsection{Lagrange-multiplikátorok}

Tekintsük a (12.1 feltételes szélsőérték-feladatot. Az implicitfüggvény-tétel segítségével feltételt adhatunk arra, hogy az $F(x, y)=c$ feltételből az $y$ változót kifejezhessük, és így megoldhassuk a feladatot. Ezt fogalmazzuk meg az alábbiakban.

12.6 Definíció. A 12.1 feladat Lagrange-függvényén az

$$
\mathscr{L}(x, y, \lambda)=f(x, y)-\lambda(F(x, y)-c)
$$

függvényt értjük, ahol $\lambda$ egyelőre tetszőleges valós szám.

12.7 Tétel. (Lagrange-módszer) Tegyük fel, hogy $\left(x_{0}, y_{0}\right)$ a 12.1 feladat megoldása, továbbá $f$ és $F$ parciális deriváltjai léteznek és folytonosak e pont környezetében. $\mathrm{Ha}$

$$
F_{2}^{\prime}\left(x_{0}, y_{0}\right) \neq 0,
$$

akkor található pontosan egy olyan $\lambda$ valós szám, amelyre

$$
\frac{\partial \mathscr{L}}{\partial x}\left(x_{0}, y_{0}, \lambda\right)=0, \quad \text { és } \quad \frac{\partial \mathscr{L}}{\partial y}\left(x_{0}, y_{0}, \lambda\right)=0
$$

Bizonyítás. A 12.2 feltételünk miatt alkalmazhatjuk az implicitfüggvény-tételt. Eszerint található olyan $g$ folytonosan differenciálható függvény, amelyre

- $g\left(x_{0}\right)=y_{0}$, és

- $F(x, g(x))=c$ az $x_{0}$ egy környezetében, továbbá

- $g^{\prime}\left(x_{0}\right)=-F_{1}^{\prime}\left(x_{0}, y_{0}\right) / F_{2}^{\prime}\left(x_{0}, y_{0}\right)$.

Ha $\left(x_{0}, y_{0}\right)$ a 12.1 feladat megoldása, akkor az $x \rightarrow f(x, g(x))$ függvénynek minimuma van az $x_{0}$ pontban, ezért itt a deriváltja nulla. Ez a derivált a láncszabály szerint

$$
f_{1}^{\prime}\left(x_{0}, y_{0}\right)+f_{2}^{\prime}\left(x_{0}, y_{0}\right) g^{\prime}\left(x_{0}\right)=f_{1}^{\prime}\left(x_{0}, y_{0}\right)-\frac{f_{2}^{\prime}\left(x_{0}, y_{0}\right)}{F_{2}^{\prime}\left(x_{0}, y_{0}\right)} F_{1}^{\prime}\left(x_{0}, y_{0}\right)=0 .
$$

Vezessük be a következő jelölést:

$$
\lambda=\frac{f_{2}^{\prime}\left(x_{0}, y_{0}\right)}{F_{2}^{\prime}\left(x_{0}, y_{0}\right)} .
$$

Ezzel a jelöléssel a fenti derivált úgy is írható, hogy:

$$
\frac{\partial \mathscr{L}}{\partial x}\left(x_{0}, y_{0}, \lambda\right)=f_{1}^{\prime}\left(x_{0}, y_{0}\right)-\lambda F_{1}^{\prime}\left(x_{0}, y_{0}\right)=0 .
$$


A tétel állításának második egyenlősége $\lambda$ behelyettesítésével nyilvánvaló azonosság, hiszen:

$$
\frac{\partial \mathscr{L}}{\partial y}\left(x_{0}, y_{0}, \lambda\right)=f_{2}^{\prime}\left(x_{0}, y_{0}\right)-\lambda F_{2}^{\prime}\left(x_{0}, y_{0}\right)=0 .
$$

Tételünket ugyanígy fogalmazhatjuk meg maximum esetére is.

\subsection{A szélsőérték-feladat megoldása}

Az előző tételünk alapján a 12.1 feltételes szélsőérték-feladat megoldásának menete a következő.

1. Állítsuk elő a feladat Lagrange-függényét.

2. Határozzuk meg az $x$ és $y$ szerinti parciális deriváltakat, és tegyük óket nullával egyenlővé.

3. Vegyük figyelembe, hogy $F\left(x_{0}, y_{0}\right)=c$.

4. Oldjuk meg az így nyert háromismeretlenes egyenletrendszert.

A megoldásként kapott $\left(x_{0}, y_{0}\right)$ kielégíti a szélsőérték szükséges feltételét. Az egyenletrendszer megoldásaként nyert $\lambda$ valós számot a feladathoz tartozó Lagrangemultiplikátornak nevezzük.

12.8 Példa. Oldjuk most meg a 12.5 Példában vizsgált feladatot Lagrange módszerével. Ekkor a feladat Lagrange-függvénye:

$$
\mathscr{L}(x, y, \lambda)=x^{2}+2 y-\lambda(x+y)
$$

Egyenletrendszerünk tehát a következő alakot ölti:

$$
\begin{aligned}
& \frac{\partial \mathscr{L}}{\partial x}\left(x_{0}, y_{0}, \lambda\right)=2 x_{0}-\lambda=0 \\
& \frac{\partial \mathscr{L}}{\partial y}\left(x_{0}, y_{0}, \lambda\right)=2-\lambda=0 \\
& \frac{\partial \mathscr{L}}{\partial \lambda}\left(x_{0}, y_{0}, \lambda\right)=x_{0}+y_{0}=0
\end{aligned}
$$

Innen azonnal adódik, hogy $\lambda=2, x_{0}=1$ és $y_{0}=-1$. 
12.9 Példa. Tekintsünk most egy kicsit bonyolultabb, és a mikroökonómiában gyakran felmerülő feladatot. Keressük meg a fogyasztói keresletre vonatkozó

$$
\begin{aligned}
& x^{\alpha} y^{\beta} \rightarrow \max \\
& p x+y=m
\end{aligned}
$$

feltételes maximumfeladat egyetlen lehetséges megoldását, ahol $\alpha, \beta, p$ és $m$ adott pozitív állandók. Ekkor

$$
f(x, y)=x^{\alpha} y^{\beta} \quad \text { és } \quad F(x, y)=p x+y,
$$

ezért a feladat Lagrange-függvénye

$$
\mathscr{L}(x, y, \lambda)=x^{\alpha} y^{\beta}-\lambda(p x+y-m) .
$$

A Lagrange-módszerrel adódó egyenletrendszer tehát

$$
\begin{aligned}
& \frac{\partial \mathscr{L}}{\partial x}\left(x_{0}, y_{0}, \lambda\right)=\alpha \cdot x_{0}^{\alpha-1} y_{0}^{\beta}-\lambda p=0 \\
& \frac{\partial \mathscr{L}}{\partial y}\left(x_{0}, y_{0}, \lambda\right)=\beta \cdot x_{0}^{\alpha} y_{0}^{\beta-1}-\lambda=0 \\
& \frac{\partial \mathscr{L}}{\partial \lambda}\left(x_{0}, y_{0}, \lambda\right)=p x_{0}+y_{0}-m=0 .
\end{aligned}
$$

Ennek az egyenletrendszernek egyetlen megoldása

$$
p x_{0}=\frac{\alpha}{\alpha+\beta} m \quad \text { és } \quad y_{0}=\frac{\alpha}{\alpha+\beta} m,
$$

a $\lambda$ Lagrange-multiplikátor a második egyenletből meghatározható.

\section{Otthoni tanuláshoz}

1. A Feladatgyújtemény-1 III/1.8 és III/5 szakaszok kidolgozott példáinak feldolgozása.

2. Házi feladatok: a III/1 szakasz 1.8.3 és 1.8.5, továbbá az III/5 szakasz 5.1.5, 5.1.6, 5.1.7 és 5.2.3 feladatai.

3. Tankönyv-1 16.3, 18.1, 18.2, 18.3, 18.4, 18.5 és 18.6 szakaszok. 
II. rész

Második félév: Valószínúségszámítás 

13. VALÓSZÍNŰSÉG 



\subsection{Kísérletek}

Az alábbiakban (véletlen) kísérletekkel és azok (véletlen) kimeneteleivel foglalkozunk. Olyan kísérleteket vizsgálunk, amelyek kimenetelét nem tudjuk előre meghatározni.

1. Földobunk egy dobókockát, és megnézzük hányast dobtunk.

2. Földobunk egy dobókockát kétszer egymás után.

3. Feldobunk egy dobókockát, majd egy érmét annyiszor, ahányat a kockával dobtunk.

4. Egy dobókockát addig dobunk, amíg először 6-ost kapunk.

5. Válasszunk az egységsugarú körlapon véletlenszerúen egy pontot.

További bonyolultabb példák:

- Egy kereszteződésen 10 és 11 óra között áthaladó autók száma.

- Egy telefonközpontba 8 és 9 között érkező hívások száma.

- Két hívás között eltelt időintervallum hossza.

- Egy részvény tôzsdei árfolyama a zárás időpontjában.

- Ügyfélszolgálati irodában a várakozási idő hossza.

\subsection{Az eseménytér}

13.1 Definíció. Jelölje a továbbiakban $\Omega$ egy kísérlet kimeneteleinek halmazát. Az $\Omega$ halmazt az adott kísérlethez tartozó eseménytérnek nevezzük.

Állítsuk elő az előző példáinkhoz tartozó eseménytereket. Ekkor sorrendben:

1. $\Omega=\{1,2,3,4,5,6\}$

2. $\Omega=\{(1,1),(1,2),(2,1),(1,3), \ldots,(6,6)\}$

3. $\Omega=\{1 F, 1 I, 2 F F, 2 F I, 2 I F, 2 I I, \ldots\}$ (Kérdés: vajon hány elemből áll ez az eseménytér?)

4. $\Omega$ mindazon véges számsorozatokból, amelynek utolsó eleme 6 , az előző elemek pedig az 1,2,3,4,5 számjegyek valamelyike.

5. $\Omega=\left\{(x, y): x^{2}+y^{2} \leq 1\right\}$ 


\subsection{Események}

13.2 Definíció. Az eseménytér részhalmazait eseményeknek nevezzük.

Tekintsük néhány példát az előző eseményterekben.

1. Jelentse $A$ azt az eseményt, hogy a dobott szám páros. Ekkor $A=\{2,4,6\}$.

2. Jelentse $A$ azt az eseményt, hogy a dobott számok összege 7. Ekkor $A=$ $\{(1,6),(6,1),(2,5),(5,2),(3,4),(4,3)\}$.

3. Jelentse $A$ azt az eseményt, hogy egyetlen Irást sem dobunk. Ekkor $A=$ $\{1 F, 2 F F, 3 F F F, 4 F F F F, 5 F F F F F, 6 F F F F F F\}$.

4. Jelentse $A$ azt az eseményt, hogy legfeljebb két dobásra van szükségünk. Ekkor $A=\{6,16,26,36,46,56\}$.

5. Jelentse $A$ azt az eseményt, hogy a választott pont a középponthoz 1/2-nél közelebb van. Ekkor $A=\left\{(x, y): x^{2}+y^{2}<1 / 4\right\}$.

\subsection{Múveletek eseményekkel}

Azt mondjuk, hogy az $A \subset \Omega$ esemény bekövetkezik, ha a kísérletnek olyan $\omega \in \Omega$ kimenetele következik be, amelyre $\omega \in A$.

A lehetetlen eseménynek egyetlen eleme sincs, jelölése: $\emptyset$ (üres halmaz). A biztos esemény: $\Omega$ (az egész eseménytér).

1. $A \cap B$ pontosan akkor következik be, ha $A$ és $B$ is bekövetkezik. Azt mondjuk, hogy $A$ és $B$ egymást kizáró események, ha $A \cap B=\emptyset$.

2. $A \cup B$ pontosan akkor következik be, ha vagy $A$ vagy $B$ bekövetkezik (vagy mindkettő).

3. $\bar{A}$ (az $A$ ellentettje, komplementere) pontosan akkor következik be, ha $A$ nem következik be.

Azt mondjuk, hogy az $A$ esemény bekövetkezése maga után vonja $B$ bekövetkezését ( $A$ implikálja $B$-t), ha $A \subset B$.

\subsection{Tétel. (De Morgan formulák)}

1. $\overline{A \cup B}=\bar{A} \cap \bar{B}$

2. $\overline{A \cap B}=\bar{A} \cup \bar{B}$ 
Ezek az azonosságok tetszóleges számú eseményre is érvényesek.

Bizonyítás. Az első egyenlőséget igazoljuk. Legyen $x \in \overline{A \cup B}$ tetszőleges. Ekkor

$$
x \in \overline{A \cup B} \Rightarrow x \notin A \cup B \Rightarrow x \notin A \text { és } x \notin B \Rightarrow x \in \bar{A} \text { és } x \in \bar{B} \Rightarrow x \in \bar{A} \cap \bar{B}
$$

Ez azt igazolja, hogy $\overline{A \cup B} \subset \bar{A} \cap \bar{B}$. A másik irányú tartalmazás (és így az egyenlőség) abból adódik, hogy a gondolatmenetben az implikációk mindegyike fordítva is igaz (és így ekvivalenciák). A második egyenlőség teljesen hasonlóan ellenőrizhetô.

Egy kísérlet elvégzésekor nem biztos, hogy minden kimenetele megfigyelhetô. Például ha két azonos kockát feldobunk, az $(1,2)$ és $(2,1)$ kimenetelekről nem dönthető el, hogy melyik következett be. Csak azt tudjuk megfigyelni, hogy az $\{(1,2),(2,1)\}$ esemény bekövetkezett.

Jelölje $\mathscr{A}$ a megfigyelhető események halmazát. Tulajdonságai:

- Ha $A \in \mathscr{A}$, akkor $\bar{A} \in \mathscr{A}$ és $\Omega \in \mathscr{A}$.

- Ha $A_{1}, A_{2}, \ldots \in \mathscr{A}$, akkor $A_{1} \cup A_{2} \cup \ldots \in \mathscr{A}$.

A továbbiakban kísérleten a $\mathscr{K}=(\Omega, \mathscr{A})$ kettőst értjük.

\subsection{Valószínúségi mező}

Tegyük fel, hogy egy $\mathscr{K}$ kísérletet $n$-szer egymás után elvégzünk és minden alkalommal megfigyeljük az $A \in \mathscr{A}$ esemény bekövetkezését. Ha az $A k_{n}$ esetben következett be, akkor az $A$ relatív gyakorisága:

$$
\frac{k_{n}}{n}
$$

A tapasztalat azt mutatja, hogy az $n$ növekedésével a relatív gyakoriság egyre kisebb kilengésekkel egy bizonyos szám körül ingadozik. Ezt tekintjük az A esemény valószínüségének.

A továbbiakban a valószínűség fogalmára olyan axiomatikus bevezetést kívánunk felépíteni, amelyből ez a tapasztalati tény levezethető.

13.4 Definíció. Tekintsünk egy $\mathscr{K}=(\Omega, \mathscr{A})$ kísérletet. A valószínüség egy

$$
P: \mathscr{A} \rightarrow[0,1]
$$

függvény, amely a következő tulajdonságokkal rendelkezik:

1. $P(\Omega)=1$

2. Ha $A_{1}, A_{2}, \ldots \in \mathscr{A}$, egymást páronként kizáró események, akkor

$$
P\left(\bigcup_{k=1}^{\infty} A_{k}\right)=\sum_{k=1}^{\infty} P\left(A_{k}\right)
$$


Ebben az esetben az $(\Omega, \mathscr{A}, P)$ hármast valószínüségi mezônek nevezzük.

Ez az axiomatikus felépítés A. N. Kolmogorovtól (1933) származik.

Az axiómákból könnyen levezethetốk a valószínúségi mező alábbi tulajdonságai.

\subsection{Tétel.}

1. Bármely $A \in \mathscr{A}$ esetén

$$
P(\bar{A})=1-P(A)
$$

és ezért $P(\emptyset)=0$.

2. Ha $A, B \in \mathscr{A}$ és $A \subset B$, akkor

$$
P(A) \leq P(B)
$$

3. $H a A, B \in \mathscr{A}$, akkor

$$
P(A \cup B)=P(A)+P(B)-P(A \cap B)
$$

Bizonyítás. Csak a 3. állítást igazoljuk. Az $A \cup B$ eseményt diszjunkt részekre bontjuk a következô módon:

$$
A \cup B=(A \cap \bar{B}) \cup(\bar{A} \cap B) \cup(A \cap B) .
$$

Ekkor a valószínúség axiómái alapján

$$
\begin{aligned}
P(A \cup B) & =P(A \cap \bar{B})+P(\bar{A} \cap B)+P(A \cap B) \\
& =P(A)-P(A \cap B)+P(B)-P(A \cap B)+P(A \cap B)
\end{aligned}
$$

ahonnan azonnal adódik az állítás.

13.6 Példa. Egy AK szakos évfolyam esetén annak a valószínúsége, hogy egy találomra választott hallgató levizsgázott matematikából 0.72, míg annak, hogy mikroökonómiából 0.66. Annak a valószínúsége, hogy mind a kettőből levizsgázott 0.54 . Mi a valószínúsége, hogy egy véletlenszerűen választott hallgató

(a) legalább az egyik tárgyból levizsgázott,

(b) levizsgázott mikroökonómiából, de matematikából nem,

(c) egyik tárgyból sem vizsgázott le.

Jelölje $A$ azt az eseményt, hogy a hallgató levizsgázott matematikából, és $B$ azt az eseményt, hogy mikroökonómiából. Ekkor $P(A)=0.72, P(B)=0.66$ és $P(A \cap B)=$ 0.54. Az $A$ és $B$ eseményekkel a kérdéses valószínúségek az alábbi módon adhatók meg.

(a) $P(A \cup B)=P(A)+P(B)-P(A \cap B)=0.84$

(b) $P(\bar{A} \cap B)=P(B)-P(A \cap B)=0.12$

(c) $P(\bar{A} \cap \bar{B})=P(\overline{A \cup B})=1-P(A \cup B)=0.16$ 


\section{Otthoni tanuláshoz}

1. A Feladatgyújtemény-2 II/ és III/3 szakaszainak feldolgozása.

2. Házi feladatok: a II szakasz 130, 131, 133, 134, 135, továbbá a III/3 szakasz 196, 198, 199 feladatai.

3. Tankönyv-2 2. fejezete és a 3.1, 3.2, 3.5 szakaszok. Továbbá: A KÖZÉPISKOLAI KOMBINATORIKA ALAPOS ÁTISMÉTLÉSE! 



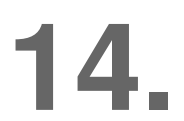

MINTAVÉTELI ELJÁRÁSOK 



\subsection{Klasszikus valószínüségi mezők}

14.1 Definíció. Tekintsünk egy $(\Omega, \mathscr{A}, P)$ valószínúségi mezőt. Ezt klasszikus valószínüségi mezônek nevezzük, ha

- $\Omega$ véges halmaz,

- Minden $\omega \in \Omega$ esetén $\{\omega\} \in \mathscr{A}$,

- Az $\Omega$ minden egyelemú részhalmaza azonos valószínúségú.

Világos, hogy ha $\Omega$ éppen $n$-elemú, akkor bármely $\omega \in \Omega$ esetén

$$
P(\{\omega\})=\frac{1}{n}
$$

Nevezetesen, ha az $A \subset \Omega$ esemény $k$ elemből áll, akkor

$$
P(A)=\frac{k}{n}
$$

Ezt úgy interpretálhatjuk, hogy az $A$ valószínúsége:

$$
P(A)=\frac{\text { kedvezó esetek száma }}{\text { összes esetek száma }}
$$

A 14.1) formulát a továbbiakban klasszikus képletnek nevezzük.

14.2 Példa. Egy szabályos dobókockát feldobunk egymás után kétszer. Mi a valószínúsége, hogy a dobott számok összege pontosan 7 ?

Jelentse $A$ azt az eseményt, hogy az összeg 7. Látható, hogy $\Omega 36$ elemú halmaz (összes esetek száma), míg $A$ egy 6 elemú részhalmaz (kedvező esetek száma), amely az $(1,6),(6,1),(2,5),(5,2),(3,4),(4,3)$ elemekből áll. Ezért

$$
P(A)=\frac{6}{36}=\frac{1}{6}
$$

a 14.1 klasszikus képlet alapján.

14.3 Példa. Egy 52 lapos kártyapakliból kihúzunk véletlenszerúen 5 lapot. Mi a valószínúsége, hogy vagy mind az 5 lap treff, vagy van közte ász? 
Vezessük be a következő jelöléseket:

$$
A=\{\text { mind az öt lap treff }\} \quad B=\{\text { van közte ász }\}
$$

Világos, hogy $P(A \cup B)$ értékét keressük. Feltételünk szerint bármelyik 5 lap húzása egyformán valószínú, ezért:

$$
P(A)=\frac{\left(\begin{array}{c}
13 \\
5
\end{array}\right)}{\left(\begin{array}{c}
52 \\
5
\end{array}\right)} \quad P(B)=1-\frac{\left(\begin{array}{c}
48 \\
5
\end{array}\right)}{\left(\begin{array}{c}
52 \\
5
\end{array}\right)}
$$

továbbá

$$
P(A \cap B)=\frac{\left(\begin{array}{c}
12 \\
4
\end{array}\right)}{\left(\begin{array}{c}
52 \\
5
\end{array}\right)}
$$

Innen

$$
P(A \cup B)=P(A)+P(B)-P(A \cap B)
$$

14.4 Példa. Egy kiárusitáson egy kosárban van 10 különböző pár cipő. Egy tolvaj véletlenszerúen elvisz 4 cipót. Mi a valószínúsége, hogy van közte legalább egy pár?

Az alábbiakban két gondolatmenetet vázolunk, de csak az egyik vezet helyes eredményre.

- Először válasszunk ki egy párt, majd a másik kettő tetszőleges lehet, tehát vagy egy újabb pár, vagy két bármilyen cipő, azaz:

$$
\frac{10\left(\begin{array}{c}
18 \\
2
\end{array}\right)}{\left(\begin{array}{c}
20 \\
4
\end{array}\right)}
$$

- Nézzük meg mi a valószínúsége, hogy a kiválasztott cipők között egyetlen pár sincs. Ezt úgy érhetjük el, hogy egy kiválasztott cipő után annak párját félretesszük. Figyeljünk arra, hogy a kiválasztásnál a sorrend nem számít, így:

$$
1-\frac{\frac{20 \cdot 18 \cdot 16 \cdot 14}{4 !}}{\left(\begin{array}{c}
20 \\
4
\end{array}\right)}
$$

Ellenőrizzük, hogy a fenti két érték nem egyenlő! Vajon melyik helyes?

14.5 Példa. Tegyük fel, hogy egy kockával addig dobunk, amíg először 6-os nem jön ki. Mi a valószínúsége, hogy páros sok dobásra van szükségünk? 
Jelentse $A$ azt az eseményt, hogy páros számú dobásra van szükségünk, illetve $A_{k}$ azt az eseményt, hogy $k$ számú dobásra van szükségünk. Világos, hogy

$$
P\left(A_{k}\right)=\left(\frac{5}{6}\right)^{k-1} \cdot \frac{1}{6}
$$

ahol $k=1,2, \ldots$ Az $A$ esemény így állítható elo:

$$
A=A_{2} \cup A_{4} \cup \ldots=\bigcup_{k=1}^{\infty} A_{2 k}
$$

A jobb oldalon álló események páronként kizárják egymást, ezért

$$
P(A)=\sum_{k=1}^{\infty} P\left(A_{2 k}\right)=\sum_{k=1}^{\infty}\left(\frac{5}{6}\right)^{2 k-1} \cdot \frac{1}{6}=\frac{5}{11}
$$

\subsection{Mintavétel visszatevés nélkül}

Tekintsünk egy $N$ számú objektumból álló halmazt, amelyek közül $m$ számú selejtes. Válasszunk ki az egész halmazból véletlenszerúen egy $n$-elemú mintát visszatevés nélkül $(n \leq m)$. Jelentse $A_{k}$ azt az eseményt, hogy a minta pontosan $k$ számú selejtes elemet tartalmaz $(0 \leq k \leq n)$. Ekkor

$$
P\left(A_{k}\right)=\frac{\left(\begin{array}{c}
m \\
k
\end{array}\right) \cdot\left(\begin{array}{c}
N-m \\
n-k
\end{array}\right)}{\left(\begin{array}{l}
N \\
n
\end{array}\right)}
$$

amelyet a visszatevés nélküli mintavétel formulájának nevezünk.

14.6 Példa. Egy 52 lapos kártyapakliból válasszunk ki véletlenszerúen 5 lapot. Mi a valószínúsége, hogy a kiválasztott lapok között pontosan 2 treff van?

jelentse $A$ a kérdéses eseményt. A visszatevés nélküli mintavétel formulája alapján

$$
P(A)=\frac{\left(\begin{array}{c}
13 \\
2
\end{array}\right) \cdot\left(\begin{array}{c}
39 \\
3
\end{array}\right)}{\left(\begin{array}{c}
52 \\
5
\end{array}\right)} .
$$

Itt értelemszerúen a treffek a "selejtes objektumok".

14.7 Példa. Keressük meg annak valószínúségét, hogy a hagyományos lottón egy véletlenszerúen kitöltött szelvénnyel legalább kettes találatunk van. 
Jelölje $A$ azt az eseményt, hogy legalább kettes találatunk van, illetve $A_{k}$ azt, hogy pontosan $k$ találatunk van. Világos, hogy az $A_{k}$ események $k=2, \ldots, 5$ esetén egymást páronként kizárják. Mivel $A=A_{2} \cup A_{3} \cup A_{4} \cup A_{5}$, ezért

$$
P(A)=\sum_{k=2}^{5} P\left(A_{k}\right)=\sum_{k=2}^{5} \frac{\left(\begin{array}{l}
5 \\
k
\end{array}\right) \cdot\left(\begin{array}{c}
85 \\
5-k
\end{array}\right)}{\left(\begin{array}{c}
90 \\
5
\end{array}\right)}
$$

hiszen az unió valószínúsége összegként áll elő.

\subsection{Mintavétel visszatevéssel}

Tekintsünk újra egy $N$ számú objektumból álló halmazt, amelyek közül $m$ számú selejtes. Válasszunk ki az egész halmazból véletlenszerúen, egyenként visszatevéssel egy $n$-elemú mintát. Jelentse $A_{k}$ azt az eseményt, hogy a minta pontosan $k$-számú selejtes elemet tartalmaz.

Vizsgáljuk meg a különböző sorrendű húzásokat. Mivel bármelyik adott sorrendben $k$ selejtes és $n-k$ nem selejtes kihúzásának valószínúsége éppen

$$
\frac{m^{k} \cdot(N-m)^{n-k}}{N^{n}}=\left(\frac{m}{N}\right)^{k}\left(1-\frac{m}{N}\right)^{n-k}
$$

és ilyen húzásból pontosan $\left(\begin{array}{l}n \\ k\end{array}\right)$ darab van, és ezek páronként kizáróak, ezért

$$
P\left(A_{k}\right)=\left(\begin{array}{l}
n \\
k
\end{array}\right)\left(\frac{m}{N}\right)^{k}\left(1-\frac{m}{N}\right)^{n-k}
$$

Ezt a visszatevéses mintavétel formulájának nevezzük.

14.8 Példa. Egy 52 lapos kártyapakliból húzzunk ki egymás után visszatevéssel véletlenszerúen 5 lapot (a kihúzott lapot húzás után mindig visszatesszük). Mi a valószínúsége, hogy

(a) pontosan 2 treffet húztunk,

(b) legalább 2 treffet húztunk.

Jelentse $A_{k}$ azt az eseményt, hogy pontosan $k$ treffet húztunk. Ekkor

$$
\text { (a) } P\left(A_{2}\right)=\left(\begin{array}{l}
5 \\
2
\end{array}\right)\left(\frac{1}{4}\right)^{2}\left(1-\frac{1}{4}\right)^{3}
$$

valamint

$$
\text { (b) } P\left(A_{2} \cup \ldots \cup A_{5}\right)=\sum_{k=2}^{5}\left(\begin{array}{l}
5 \\
k
\end{array}\right)\left(\frac{1}{4}\right)^{k}\left(\frac{3}{4}\right)^{5-k}
$$

hiszen az $A_{2}, \ldots, A_{5}$ események páronként kizárják egymást. 


\subsection{A Bernoulli-kísérlet}

A fenti gondolatmenet általánosítható is a következő módon. Tegyük fel, hogy egy kísérletben az $A$ esemény bekövetkezésének valószínúsége valamely adott $0 \leq p \leq 1$ szám.

Tegyük fel, hogy elvégezzük ezt a kísérletet (egymástól függetlenül) egymás után $n$-szer, és minden esetben megfigyeljük, hogy az $A$ esemény bekövetkezik-e vagy sem. Ezt a kísérletsorozatot Bernoulli-féle kísérletnek nevezzük.

Legyen $0 \leq k \leq n$ adott természetes szám. Jelentse $A_{k}$ azt az eseményt, hogy az $n$ számú kísérletből $A$ pontosan $k$ esetben következik be.

A visszatevéses mintavételnél követett gondolatmenetet alkalmazva láthatjuk, hogy a kérdéses valószínûség:

$$
P\left(A_{k}\right)=\left(\begin{array}{l}
n \\
k
\end{array}\right) p^{k}(1-p)^{n-k}
$$

bármely $k=0,1, \ldots, n$ esetén.

14.9 Példa. Egy hagyományos lottószelvény esetében azt mondjuk, hogy nyerő, ha legalább kéttalálatos. Vásárolunk 20 szelvényt, és véletlenszerúen (egymástól függetlenül) kitöltjük ôket. Mi a valószínúsége, hogy legalább 5 nyerô szelvényünk lesz?

Világos, hogy egyetlen szelvény esetében annak valószínúsége, hogy nyerő:

$$
p=\sum_{k=2}^{5} \frac{\left(\begin{array}{l}
5 \\
k
\end{array}\right) \cdot\left(\begin{array}{c}
85 \\
5-k
\end{array}\right)}{\left(\begin{array}{c}
90 \\
5
\end{array}\right)}
$$

Mivel ez mindegyik szelvényre érvényes, és a szelvényeket egymástól függetlenül töltöttük ki, eredeti feladatunk egy Bernoulli-féle kísérletnek tekinthető ezzel a $p$ paraméterrel. Tehát a kérdéses valószínúség:

$$
\sum_{k=5}^{20}\left(\begin{array}{c}
20 \\
k
\end{array}\right) p^{k}(1-p)^{20-k}
$$

ahol $p$ a fenti valószínúség.

\section{Otthoni tanuláshoz}

1. A Feladatgyújtemény-2 III/1 szakaszának feldolgozása.

2. Házi feladatok: a III/3 szakasz 143, 144, 145, 153, 154, 157, 159, 165 és 173 feladatai.

3. Tankönyv-2 3.3 szakasza. Továbbá: A KÖZÉPISKOLAI KOMBINATORIKA ALAPOS ÁTISMÉTLÉSE! 



\section{5.}

FELTÉTELES VALÓSZíNŰSÉG ÉS BAYES-TETEL 



\subsection{Feltételes valószínűség}

Számos esetben kell az $A$ esemény valószínúségét meghatározni olyan a priori feltétel mellett, hogy valamely $B$ eseményről tudjuk, hogy bekövetkezett. Ilyen esetekben az eseménytér elemei közül csak azokat vesszük számításba, amelyek a $B$-nek is elemei.

Ez azt jelenti, hogy az $\Omega$ helyett az eseményteret a $B$ eseményre szúkítjük, és erre vonatkozóan számítjuk ki egy $A$ esemény (feltételes) valószínúségét.

15.1 Definíció. Tekintsünk egy $(\Omega, \mathscr{A}, P)$ valószínúségi mezőt és egy olyan $B \in \mathscr{A}$ eseményt, amelyre $P(B) \neq 0$. Az $A \in \mathscr{A}$ esemény $B$-re vonatkozó feltételes valószínúségén az alábbit értjük:

$$
P(A \mid B)=\frac{P(A \cap B)}{P(B)}
$$

15.2 Példa. Tegyük fel, hogy két kockával dobunk, de nem látjuk az eredményt. Valaki megmondta, hogy az egyik dobás 5-ös. Mi a valószínúsége, hogy a másik 6-os?

Figyelem, az eredmény nem $1 / 6$ lesz!

Jelentse $A$ és $B$ a következő eseményeket:

$$
B=\{\text { az egyik dobás 5-ös }\} \quad A=\{\text { a másik dobás 6-os }\}
$$

Ekkor $P(B)=11 / 36$ hiszen 11 olyan számpár van, amelyben az 5-ös szerepel. Másrészt $A \cap B=\{(5,6),(6,5)\}$, ezért $P(A \cap B)=2 / 36$. Tehát

$$
P(A \mid B)=\frac{P(A \cap B)}{P(B)}=\frac{2 / 36}{11 / 36}=\frac{2}{11}
$$

15.3 Példa. Egy ismerôsünket keressük az egyetemen, aki 5 különböző teremben lehet egyforma valószínúséggel. Annak valószínúsége, hogy egyáltalalán az egyetemen van $0<p<1$. Az 5 terem közül már 4-ben kerestük, de egyikben sem volt. Mi a valószínúsége, hogy az 5-ik teremben van? 
Jelentse $A_{k}$ azt az eseményt, hogy az ismerősünk a $k$-ik teremben van $(k=1, \ldots 5)$, ekkor $P\left(A_{1} \cup \ldots \cup A_{5}\right)=p$. Mivel az $A_{k}$ események egymást páronként kizárják, innen $P\left(A_{k}\right)=p / 5$ mindegyik $k$ indexre. Tehát a De Morgan azonosság alapján:

$$
\begin{aligned}
P\left(A_{5} \mid \overline{A_{1}} \cap \ldots \cap \overline{A_{4}}\right) & =P\left(A_{5} \mid \overline{A_{1} \cup \ldots \cup A_{4}}\right) \\
& =\frac{P\left(A_{5} \cap\left(\overline{A_{1} \cup \ldots \cup A_{4}}\right)\right.}{P\left(\overline{A_{1} \cup \ldots \cup A_{4}}\right)}
\end{aligned}
$$

Nyilvánvaló, hogy

$$
A_{5} \subset \overline{A_{1} \cup \ldots \cup A_{4}}
$$

és ezért

$$
P\left(A_{5} \cap\left(\overline{A_{1} \cup \ldots \cup A_{4}}\right)\right)=P\left(A_{5}\right)
$$

Tehát a kérdéses valószínűség:

$$
\begin{aligned}
P\left(A_{5} \mid \overline{A_{1}} \cap \ldots \cap \overline{A_{4}}\right) & =P\left(A_{5} \mid \overline{A_{1} \cup \ldots \cup A_{4}}\right) \\
& =\frac{P\left(A_{5} \cap\left(\overline{A_{1} \cup \ldots \cup A_{4}}\right)\right)}{P\left(\overline{A_{1} \cup \ldots \cup A_{4}}\right)} \\
& =\frac{P\left(A_{5}\right)}{P\left(\overline{A_{1} \cup \ldots \cup A_{4}}\right)}=\frac{p / 5}{1-4 p / 5}=\frac{p}{5-4 p}
\end{aligned}
$$

\subsection{Függetlenség}

Tekintsük a következő nagyon egyszerú példát. Két kockával dobunk, de az eredményt nem látjuk. Valaki megmondta, hogy az elsô dobás páratlan. Mi a valószínúsége, hogy a dobott számok összege 7 ?

Jelentse $A$ és $B$ a következő eseményeket:

$$
A=\{\text { az összeg } 7\} \quad B=\{\text { az első dobás páratlan }\}
$$

Ekkor a feltételes valószínúség definíciója szerint

$$
P(A \mid B)=\frac{P(A \cap B)}{P(B)}=\frac{3 / 36}{18 / 36}=\frac{1}{6}
$$

Ez a korábbi példánkra tekintettel azt jelenti, hogy

$$
P(A \mid B)=P(A)
$$

azaz "a $B$ esemény bekövetkezése nem befolyásolja az $A$ valószínúségét". Ezt úgy fogalmazzuk meg, hogy $A$ független a $B$ eseménytől. 
Világos, hogy $P(B) \neq 0$ esetén a $P(A \mid B)=P(A)$ feltétel ekvivalens a következővel:

$$
P(A \cap B)=P(A) \cdot P(B)
$$

Mivel úgy képzeljük, hogy a függetlenség szimmetrikus reláció (azaz ha $A$ független $B$ től, akkor $B$ is $A$-tól), és a fenti egyenlőség esetében ez nyilvánvalóan látható, célszerú ez utóbbi egyenlőséget a függetlenség definíciójául használni.

15.4 Definíció. Legyen $(\Omega, \mathscr{A}, P)$ adott valószínűségi mező és $A, B \in \mathscr{A}$ megfigyelhető események. Azt mondjuk, hogy $A$ és $B$ függetlenek, ha fennáll az 15.1 egyenlőség.

15.5 Példa. Egy 52 lapos kártyapakliból kihúzunk egymás után visszatevéssel két lapot. Mi a valószínúsége, hogy elsőre treffet, másodikra ászt húzunk?

Vezessük be a következő eseményeket:

$$
A=\{\text { elsôre treffet húzunk }\} \quad B=\{\text { másodikra ászt húzunk }\}
$$

Ekkor

$$
P(A \cap B)=\frac{13 \cdot 4}{52^{2}}=\frac{13}{52} \cdot \frac{4}{52}=P(A) \cdot P(B)
$$

azaz az $A$ és $B$ események függetlenek.

Figyelem! Soha nem úgy érvelünk, hogy mivel $A$ és $B$ "láthatóan" függetlenek, azért $P(A \cap B)=P(A) \cdot P(B)$. Fordítva: az események függetlenségére úgy következtetünk, hogy ezt az egyenlőséget ellenőrizzük!

\subsection{Teljes valószínúség tétele}

15.6 Példa. Három egyforma boríték van előttünk,

1. az elsőben 2 darab ezres és 3 kétezres bankjegy,

2. a másodikban 5 ezres és 2 kétezres,

3. a harmadikban 5 kétezres bankjegy.

Véletlenszerűen kiválasztunk egy borítékot, majd abból találomra kihúzunk egy bankjegyet. Mi a valószínúsége, hogy kétezrest húzunk?

Jelentse $A$ azt az eseményt, hogy kétezrest húzunk. Nyilván $P(A)$ könnyen meghatározható lenne, ha tudnánk, melyik borítékot választottuk. Nevezetesen, ha $B_{k}$ jelöli azt az eseményt, hogy a $k$-ik borítékot választottuk, akkor a $P\left(A \mid B_{k}\right)$ feltételes valószínúségek rendre $3 / 5,2 / 7$ és 1 . 
Ez az észrevétel azonnal útmutatást is ad a megoldásra, ugyanis a $B_{k}$ események egymást páronként kizárják, és egyesítésük a biztos esemény. Tehát:

$$
A=A \cap \Omega=A \cap\left(B_{1} \cup B_{2} \cup B_{3}\right)=\left(A \cap B_{1}\right) \cup\left(A \cap B_{2}\right) \cup\left(A \cap B_{3}\right)
$$

Mivel a jobb oldali események egymást páronként kizárják:

$$
\begin{aligned}
P(A) & =P\left(A \cap B_{1}\right)+P\left(A \cap B_{2}\right)+P\left(A \cap B_{3}\right) \\
& =P\left(A \mid B_{1}\right) P\left(B_{1}\right)+P\left(A \mid B_{2}\right) P\left(B_{2}\right)+P\left(A \mid B_{3}\right) P\left(B_{3}\right) \\
& =\frac{3}{5} \cdot \frac{1}{3}+\frac{2}{7} \cdot \frac{1}{3}+1 \cdot \frac{1}{3}
\end{aligned}
$$

Ez a gondolatmenet nyilván továbbvihetố tetszőleges számú $B_{k}$ eseményre is, ezért vezessük be a következő definíciót.

15.7 Definíció. Azt mondjuk, hogy a $B_{1}, B_{2}, \ldots \in \mathscr{A}$ megfigyelhető események teljes eseményrendszert alkotnak, ha egyik sem nulla valószínúségú, továbbá

1. egymást páronként kizárják, azaz $B_{i} \cap B_{j}=\emptyset$ ha $i \neq j$,

2. egyikük biztosan bekövetkezik, azaz $B_{1} \cup B_{2} \cup \ldots=\Omega$.

A 15.6 Példában alkalmazott gondolatmenetet követve tetszőleges számú $B_{k}$ eseményre adódik a következő tételünk.

15.8 Tétel. (Teljes valószínúség tétele) Tegyük fel, hogy az $(\Omega, \mathscr{A}, P)$ valószínüségi mezóben a $B_{1}, B_{2}, \ldots$ nem nulla valószínüségü események teljes eseményrendszert alkotnak. Akkor tetszóleges $A \in \mathscr{A}$ eseményre

$$
P(A)=P\left(A \mid B_{1}\right) P\left(B_{1}\right)+P\left(A \mid B_{2}\right) P\left(B_{2}\right)+\ldots
$$

Bizonyítás. Valóban, ha a $B_{k}$ események teljes eseményrendszert alkotnak, akkor

$$
A=\left(A \cap B_{1}\right) \cup\left(A \cap B_{2}\right) \cup\left(A \cap B_{3}\right) \cup \ldots
$$

ahol az unió tagjai egymást páronként kizárják. Innen

$$
P(A)=P\left(A \cap B_{1}\right)+P\left(A \cap B_{2}\right)+P\left(A \cap B_{3}\right)+\ldots
$$

Mivel a feltételes valószínúség definíciója alapján minden $k$ indexre

$$
P\left(A \cap B_{k}\right)=P\left(A \mid B_{k}\right) \cdot P\left(B_{k}\right)
$$

innen azonnal adódik a tétel állítása.

15.9 Példa. Ha például annak valószínúsége, hogy egy telefonközpontba egy adott napon $n$ hívás érkezik $0<q_{n}<1$, és mindegyik hívás adott $0<p<1$ valószínúséggel téves, akkor mi a valószínúsége, hogy ezen a napon éppen $k$ számú téves hívás érkezik? 
Vezessük be a következő jelöléseket. Jelentse $A$ azt az eseményt, hogy központba $k$ számú téves hívás érkezik, illetve $B_{n}$ azt az eseményt, hogy az adott napon a beérkező hívások száma éppen $n$. Ekkor a $B_{n}$ események teljes eseményrendszert alkotnak, ezért a teljes valószínúség tétele alapján

$$
P(A)=\sum_{n=1}^{\infty} P\left(A \mid B_{n}\right) \cdot P\left(B_{n}\right)=\sum_{n=k}^{\infty} q_{n}\left(\begin{array}{l}
n \\
k
\end{array}\right) p^{k}(1-p)^{n-k}
$$

ugyanis $n \geq k$ esetén a téves hívások egy Bernoulli-féle kísérlet eredményeként adódnak: $n$ számú kísérletből hányszor következik be a téves hívás. Vegyük még figyelembe, hogy itt $P\left(A \mid B_{n}\right)=0$, ha $n<k$.

\subsection{Bayes-tétel}

Térjünk vissza a 15.6Példa vizsgálatára. Tegyük fel, hogy valaki elvégezte a húzást (mi nem láttuk), és közölte, hogy kétezres bankjegyet húzott. Mi a valószínúsége, hogy az elsô borítékból húzta?

Az ottani jelöléseinket használva a $P\left(B_{1} \mid A\right)$ feltételes valószínűségről van szó.

$$
P\left(B_{1} \mid A\right)=\frac{P\left(A \cap B_{1}\right)}{P(A)}=\frac{P\left(A \mid B_{1}\right) P\left(B_{1}\right)}{P(A)}
$$

Az utóbbi tört nevezője a Teljes valószínúség tételével határozható meg. Tehát:

$$
\begin{aligned}
P\left(B_{1} \mid A\right) & =\frac{P\left(A \mid B_{1}\right) P\left(B_{1}\right)}{P\left(A \mid B_{1}\right) P\left(B_{1}\right)+P\left(A \mid B_{2}\right) P\left(B_{2}\right)+P\left(A \mid B_{3}\right) P\left(B_{3}\right)} \\
& =\frac{\frac{3}{5} \cdot \frac{1}{3}}{\frac{3}{5} \cdot \frac{1}{3}+\frac{2}{7} \cdot \frac{1}{3}+1 \cdot \frac{1}{3}}
\end{aligned}
$$

Ez a gondolatmenetünk általánosítható tetszőleges elemszámú teljes eseményrendszerre is.

15.10 Tétel. (Bayes-tétel) Tegyük fel, hogy az $(\Omega, \mathscr{A}, P)$ valószínüségi mezóben a $B_{1}, B_{2}, \ldots$ nem nulla valószínúségü események teljes eseményrendszert alkotnak. Akkor tetszóleges $A \in \mathscr{A}, P(A) \neq 0$ eseményre és $i$ indexre

$$
P\left(B_{i} \mid A\right)=\frac{P\left(A \mid B_{i}\right) P\left(B_{i}\right)}{P\left(A \mid B_{1}\right) P\left(B_{1}\right)+P\left(A \mid B_{2}\right) P\left(B_{2}\right)+\ldots}
$$


Bizonyítás. Valóban, a feltételes valószínúség definíciója alapján

$$
P\left(B_{i} \mid A\right)=\frac{P\left(A \cap B_{i}\right)}{P(A)}=\frac{P\left(A \mid B_{i}\right) P\left(B_{i}\right)}{P(A)},
$$

és innen a teljes valószínúség tétele alapján adódik az állítás.

15.11 Példa. Például a telefonközpontos 15.9 példánkban annak valószínúsége, hogy az adott napon $i$ hívás érkezett feltéve, hogy éppen $k$ téves hívást regisztráltak $i \geq k$ esetén:

$$
P\left(B_{i} \mid A\right)=\frac{q_{i}\left(\begin{array}{l}
i \\
k
\end{array}\right) p^{k}(1-p)^{i-k}}{\sum_{n=k}^{\infty} q_{n}\left(\begin{array}{l}
n \\
k
\end{array}\right) p^{k}(1-p)^{n-k}}
$$

míg $i<k$ esetén ez a feltételes valószínúség 0 .

\section{Otthoni tanuláshoz}

1. A Feladatgyújtemény-2 III/4 és III/5 szakaszainak feldolgozása.

2. Házi feladatok: a III/4 szakasz 228, 229, 232, 233, 237, 242, 251, 257 továbbá a III/4 szakasz 264, 265, 269, 270, 280 feladatai.

3. Tankönyv-2 3.6, 3.7, 3.8 és 3.9 szakaszai. Továbbá: A KÖZÉPISKOLAI KOMBINATORIKA ALAPOS ÁTISMÉTLÉSE! 


\section{6.}

\section{VALÓSZÍNŰSÉGI VÁLTOZÓK ÉS}

ELOSZLÁSOK 



\subsection{Valószínúségi változók}

16.1 Definíció. Tekintsünk egy $(\Omega, \mathscr{A}, P)$ valószínúségi mezőt. Az

$$
X: \Omega \rightarrow \mathbb{R}
$$

függvényt valószínúségi változónak nevezünk, ha bármely $x \in \mathbb{R}$ esetén

$$
\{X<x\}=\{\omega \in \Omega: X(\omega)<x\} \in \mathscr{A}
$$

azaz minden ilyen nívóhalmaz megfigyelhető (és így van valószínûsége).

Az alábbi példákban állapítsuk meg a megadott valószínúségi változók $R$ értékkészletét!

\subsection{Példa.}

1. Két kockával dobunk. Jelentse $X$ a dobott számok összegét. Ekkor $R=$ $\{2,3, \ldots, 12\}$

2. Jelentse $X$ a hagyományos lottón kihúzott öt nyerő szám közül a legkisebbet. Ekkor $R=\{1,2, \ldots, 86\}$

3. Egy kockával addig dobunk, amíg először 6-os jön ki. Jelentse $X$ a dobások számát. Ekkor $R=\mathbb{N}$.

4. Válasszunk az origó középpontú egységsugarú körlemezben véletlenszerúen egy pontot. Jelentse $X$ a pont origótól mért távolságát. Ekkor $R=[0,1]$.

16.3 Definíció. Egy valószínûségi változót diszkrétnek nevezünk, ha az értékkészlete véges vagy végtelen sorozatba rendezhető (azaz megszámlálható halmaz).

Példáinkban az első három változó diszkrét, míg a negyedik nem az.

\subsection{Diszkrét valószínúségi változó eloszlása}

16.4 Definíció. Legyen $X$ diszkrét valószínúségi változó, amelynek értékkészlete $R=$ $\left\{x_{1}, x_{2}, \ldots\right\}$. Ekkor a

$$
p_{k}=P\left(X=x_{k}\right), \quad k=1,2, \ldots
$$

sorozatot az $X$ eloszlásának nevezzük.

16.5 Példa. Tekintsük a bevezetô példáinkat diszkrét valószínúségi változókra. 
1. Ha $X$ a két dobott szám összegét jelenti, akkor az eloszlás az alábbi táblázattal adható meg:

\begin{tabular}{c|c|c|c|c|c}
$x_{k}$ & 2 & 3 & 4 & $\ldots$ & 12 \\
\hline$p_{k}$ & $\frac{1}{36}$ & $\frac{2}{36}$ & $\frac{3}{36}$ & $\ldots$ & $\frac{1}{36}$
\end{tabular}

2. Ha $X$ a legkisebb kihúzott lottószámot jelenti, akkor az eloszlás az alábbi formulával adható meg:

$$
p_{k}=\frac{\left(\begin{array}{c}
90-k \\
4
\end{array}\right)}{\left(\begin{array}{c}
90 \\
5
\end{array}\right)} \quad k=1,2, \ldots 86
$$

3. Ha $X$ az első 6-osig szükséges dobások száma, akkor $X$ eloszlása:

$$
p_{k}=\left(\frac{5}{6}\right)^{k-1} \cdot \frac{1}{6} \quad k=1,2, \ldots
$$

Az előző két példától eltérően az eloszlás itt végtelen sorozat.

Az eloszlás legfontosabb tulajdonságait a következő tételben foglaljuk össze.

16.6 Tétel. Tekintsünk egy $X$ diszkrét valószínüségi változót, amelynek értékkészlete $R=\left\{x_{1}, x_{2}, \ldots\right\}$ és eloszlása $p_{k}=P\left(X=x_{k}\right), k=1,2, \ldots$ Ekkor

- $0 \leq p_{k} \leq 1$ minden $k=1,2, \ldots$ indexre.

- $p_{1}+p_{2}+\ldots=1$.

- Ha a $<$ b tetszóleges valós számok, akkor

$$
P(a<X<b)=\sum_{a<x_{k}<b} p_{k}
$$

ahol mindazon $p_{k}$ valószínüségeket összegezzük, amelyek indexeire fennáll az $a<x_{k}<b$ egyenlötlenség. Itt bármelyik szigorú egyenlótlenség helyett mindkét oldalon egyszerre $\leq$ is használható.

\subsection{Az eloszlásfüggvény}

16.7 Definíció. Tekintsünk egy $(\Omega, \mathscr{A}, P)$ valószínúségi mezőt és egy $X: \Omega \rightarrow \mathbb{R}$ valószínúségi változót. Minden $x \in \mathbb{R}$ esetén legyen

$$
F(x)=P(X<x)
$$

Az így értelmezett $F: \mathbb{R} \rightarrow[0,1]$ függvényt az $X$ eloszlásfüggvényének nevezzük. 
16.8 Példa. Könnyen ellenőrizhető, hogy a körlemezes példánkban (bevezetô 4. példa) az $X$ változó eloszlásfüggvénye

$$
F(x)= \begin{cases}0 & \text { ha } x \leq 0 \\ x^{2} & \text { ha } 0<x \leq 1 \\ 1 & \text { ha } x>1\end{cases}
$$

Úgy képzeljük ugyanis, hogy annak valószínúsége, hogy a véletlenszerúen választott pont a körlemez egy adott részhalmazában van, arányos a részhalmaz területével. Nevezetesen például $P(0 \leq X<1 / 2)=1 / 4$.

A valószínúségszámítás és a statisztika számos feladatában van szükség valamely $P(a \leq X<b)$ alakú valószínűség meghatározására. Ehhez nyújt segítséget az eloszlásfüggvény, amelynek tulajdonságait az alábbi tételben foglaljuk össze.

16.9 Tétel. Tekintsünk egy X valószínüségi változót és jelölje $F$ az X eloszlásfüggvényét.

- Minden $x \in \mathbb{R}$ esetén $0 \leq F(x) \leq 1$.

- F monoton növó és minden pontban balról folytonos.

- $\lim _{x \rightarrow-\infty} F(x)=0$ és $\lim _{x \rightarrow+\infty} F(x)=1$.

- Ha a < b tetszólegesen adott valós számok, akkor

$$
P(a \leq X<b)=F(b)-F(a) .
$$

Ha egy $X$ diszkrét valószínúségi változó értékkészlete $R=\left\{x_{1}, x_{2}, \ldots\right\}$ ahol $x_{1}<$ $x_{2}<\ldots$, és $X$ ezeket az értékeket rendre $p_{1}, p_{2}, \ldots$ valószínúségekkel veszi fel, akkor az $X$ eloszlásfüggvénye ilyen alakú:

$$
F(x)= \begin{cases}0 & \text { ha } x \leq x_{1} \\ p_{1}+\ldots+p_{k} & \text { ha } x_{k}<x \leq x_{k+1}\end{cases}
$$

bármely $k=1,2, \ldots$ esetén. Készítsünk grafikont!

Ez azt jelenti, hogy ilyen esetben az eloszlásfüggvény szakaszonként konstans. Célszerú ilyenkor az $P(a \leq X<b)=F(b)-F(a)$ képlet alkalmazása helyett összegyújteni az $X$ értékkészletének mindazon elemeit, amelyek $a$ és $b$ közé esnek. Nevezetesen ha $P\left(X=x_{k}\right)=p_{k}$ minden $k$-ra:

$$
P(a \leq X<b)=\sum_{a \leq x_{k}<b} p_{k}
$$

Mivel itt csak a $P\left(X=x_{k}\right)$ valószínúségek szerepelnek, vezessük be a diszkrét változó eloszlásának fogalmát. 


\subsection{A sürüségfüggvény}

16.10 Definíció. Azt mondjuk, hogy $X$ folytonos eloszlású, ha található olyan $f$ integrálható függvény a számegyenesen, amelyre

$$
F(x)=\int_{-\infty}^{x} f(t) d t
$$

minden $x \in \mathbb{R}$ mellett. Ilyenkor az $f$ függvényt az $X$ sürüségfüggvényének nevezzük.

Például az 16.1 példában könnyen ellenôrizhető, hogy

$$
f(t)= \begin{cases}2 t & \text { ha } 0<t<1 \\ 0 & \text { különben }\end{cases}
$$

Ha az $X$ valószínúségi változó folytonos eloszlású, akkor az $F$ eloszlásfüggvény folytonos, és minden olyan $x$ pontban, ahol az $f$ sürúségfüggvény folytonos $F$ differencálható és:

$$
F^{\prime}(x)=f(x)
$$

16.11 Tétel. Ha X folytonos eloszlású és $f$ a sûrüségfüggvénye, akkor bármely $a<b$ esetén

$$
P(a \leq X<b)=\int_{a}^{b} f(t) d t
$$

Vajon milyen valószínúséggel vesz fel egy $X$ valószínúségi változó egyetlen pontot? Legyen $a \in \mathbb{R}$ tetszőleges, ekkor belátható, hogy

$$
\begin{aligned}
P(X=a) & =P\left(\bigcap_{n=1}^{\infty}\left\{a \leq X<a+\frac{1}{n}\right\}\right)=\lim _{n \rightarrow \infty} P\left(a \leq X<a+\frac{1}{n}\right) \\
& =\lim _{n \rightarrow \infty}\left(F\left(a+\frac{1}{n}\right)-F(a)\right)=\lim _{x \rightarrow a+} F(x)-F(a)
\end{aligned}
$$

Tehát $P(X=a)$ az $F$ a-pontbeli "ugrásával" egyenlő.

Elôző gondolatmenetünk azt jelenti, hogy $P(X=a)=0$ akkor és csak akkor áll fenn, ha $F$ folytonos az a pontban. Nevezetesen, ha $X$ folytonos eloszlású, akkor $F$ folytonos az egész számegyenesen, tehát bármely $a<b$ valós számokra

$$
P(a<X<b)=P(a \leq X \leq b)
$$

Foglaljuk össze a sûrűségfüggvény tulajdonságait.

16.12 Tétel. Ha $f$ az $X$ valószínüségi változó sürüségfüggvénye, akkor 
1. $f(x) \geq 0$ minden $x \in \mathbb{R}$ esetén

2.

$$
\int_{-\infty}^{+\infty} f(x) d x=1
$$

3. ha a $<$ b tetszóleges valós számok, akkor

$$
P(a<X<b)=P(a \leq X \leq b)=\int_{a}^{b} f(x) d x
$$

16.13 Példa. Legyen például az $X$ sûrúségfüggvénye

$$
f(x)= \begin{cases}x & \text { ha } 0<x \leq 1 \\ 2-x & \text { ha } 1<x<2 \\ 0 & \text { különben }\end{cases}
$$

Könnyen ellenôrizhetjük, hogy $f$ valóban kielégíti az előző tétel feltételeit. Ekkor például

$$
\begin{aligned}
P(0 \leq X \leq 3 / 2) & =P(0<X<3 / 2)=\int_{0}^{3 / 2} f(x) d x \\
& =\int_{0}^{1} x d x+\int_{1}^{3 / 2}(2-x) d x \\
& =1-\int_{3 / 2}^{2}(2-x) d x=\frac{7}{8}
\end{aligned}
$$

\section{Otthoni tanuláshoz}

1. A Feladatgyưjjtemény-2 IV/1 szakaszának feldolgozása.

2. Házi feladatok: a IV/1 szakasz 299, 303, 306, , 314, 316, 323 és 324 feladatai.

3. Tankönyv-2 4.1, 4.2, 4.3, 4.4 szakaszai. 

17.

A VÁRHATÓ ÉRTÉK ÉS A SZÓRÁS 

Hétköznapi szóhasználattal egy valószínúségi változó várható értéke az átlagértékét, a szórása pedig az átlagtól való átlagos eltérést jelenti. A pontos definíciókat az alábbiakban fogalmazzuk meg.

\subsection{Diszkrét eloszlások várható értéke}

17.1 Definíció. Tekintsünk egy $X$ diszkrét valószínúségi változót, amelynek eloszlása

$$
P\left(X=x_{k}\right)=p_{k} \quad k=1,2, \ldots
$$

Azt mondjuk, hogy az $X$-nek van várható értéke, ha a $\sum_{k=1}^{\infty}\left|x_{k}\right| \cdot p_{k}$ sor konvergens, és ekkor az

$$
E(X)=\sum_{k=1}^{\infty} x_{k} \cdot p_{k}
$$

sorösszeget az X várható értékének nevezzük.

Megjegyezzük, hogy a $\sum_{k=1}^{\infty}\left|x_{k}\right| \cdot p_{k}$ sor konvergenciája azért fontos feltétel, mert ellenkező esetben $E(X)$ értéke függhetne a sor tagjainak sorrendjétől.

17.2 Példa. Egy kockát feldobunk kétszer egymás után. Határozzuk meg a dobott számok összegének várható értékét.

Jelentse $X$ a dobott számok összegét, akkor $X$ eloszlását a 16.5 Példában láthatjuk. Tehát a definíció szerint a várható érték:

$$
E(X)=\sum_{k=2}^{12} k p_{k}=2 \cdot \frac{1}{36}+3 \cdot \frac{2}{36}+\ldots+12 \cdot \frac{1}{36}=7 .
$$

17.3 Példa. Egy 52 lapos kártyapakliból véletlenszerúen válasszunk ki 5 lapot. Adjuk meg a kihúzott treffek számának várható értékét.

Jelentse $X$ a kihúzott treffek számát, akkor a visszatevés nélküli mintavételi feladat alapján az $X$ eloszlása:

$$
P(X=k)=\frac{\left(\begin{array}{c}
13 \\
k
\end{array}\right) \cdot\left(\begin{array}{c}
39 \\
5-k
\end{array}\right)}{\left(\begin{array}{c}
52 \\
5
\end{array}\right)} \quad k=0, \ldots, 5
$$

Ennek alapján a várható érték:

$$
\begin{aligned}
E(X) & =\sum_{k=0}^{5} k P(X=k)=\sum_{k=0}^{5} k \frac{\left(\begin{array}{c}
13 \\
k
\end{array}\right) \cdot\left(\begin{array}{c}
39 \\
5-k
\end{array}\right)}{\left(\begin{array}{c}
52 \\
5
\end{array}\right)} \\
& =\frac{13}{\left(\begin{array}{c}
52 \\
2
\end{array}\right)} \sum_{k=1}^{5}\left(\begin{array}{c}
12 \\
k-1
\end{array}\right)\left(\begin{array}{c}
39 \\
4-(k-1)
\end{array}\right)=\frac{5 \cdot 13}{52} .
\end{aligned}
$$


17.4 Példa. Tekintsük a 2.6 fejezetben vizsgált Bernoulli-kísérletet, és határozzuk meg, hogy $n$ kísérletből várhatóan hányszor következik be az $A$ esemény.

Jelentse $X$ az $A$ esemény bekövetkezéseinek számát, ekkor $X$ eloszlása:

$$
P(X=k)=\left(\begin{array}{l}
n \\
k
\end{array}\right) p^{k}(1-p)^{n-k} \quad k=0,1, \ldots, n
$$

Tehát $X$ várható értéke a binomiális tétel alapján

$$
\begin{aligned}
E(X) & =\sum_{k=0}^{n} k\left(\begin{array}{l}
n \\
k
\end{array}\right) p^{k}(1-p)^{n-k} \\
& =n p \sum_{k=1}^{n} \frac{(n-1) !}{(k-1) !(n-k) !} p^{k-1}(1-p)^{n-k} \\
& =n p \sum_{k=1}^{n}\left(\begin{array}{l}
n-1 \\
k-1
\end{array}\right) p^{k-1}(1-p)^{n-k}=n p
\end{aligned}
$$

\subsection{Végtelen elemű eloszlások várható értéke}

Ebben a szakaszban olyan példákat vizsgálunk, ahol a diszkrét valószínúségi változó értékkészlete végtelen halmaz.

17.5 Példa. Egy kockát ismételten addig dobunk, amíg 6-os nem jön ki. Mennyi a dobások számának várható értéke?

Jelentse $X$ a dobások számát, akkor $X$ eloszlása

$$
P(X=k)=\left(\frac{5}{6}\right)^{k-1} \cdot \frac{1}{6} \quad k=1,2, \ldots
$$

Tehát a várható érték

$$
E(X)=\sum_{k=1}^{\infty} k \cdot\left(\frac{5}{6}\right)^{k-1} \cdot \frac{1}{6}=\frac{1}{6} \cdot \frac{1}{(1-5 / 6)^{2}}=6
$$


17.6 Példa. Legyen $\lambda$ adott pozitív szám, és $X$ olyan valószínűségi változó, amelynek eloszlása

$$
P(X=k)=\frac{\lambda^{k}}{k !} e^{-\lambda} \quad k=0,1,2, \ldots
$$

Ekkor az exponenciális függvény hatványsora alapján az $X$ várható értéke:

$$
\begin{aligned}
E(X) & =\sum_{k=0}^{\infty} k \frac{\lambda^{k}}{k !} e^{-\lambda}=\lambda \sum_{k=1}^{\infty} \frac{\lambda^{k-1}}{(k-1) !} e^{-\lambda} \\
& =\lambda e^{-\lambda} \sum_{i=0}^{\infty} \frac{\lambda^{i}}{i !}=\lambda e^{-\lambda} e^{\lambda}=\lambda
\end{aligned}
$$

17.7 Példa. Egy dobozban 1 fekete és 1 fehér golyó van. Találomra kiveszünk egyet. Ha fekete, akkor visszatesszük, és hozzáteszünk még egy fekete golyót. A húzásokat addig folytatjuk, amíg a fehér golyót ki nem húzzuk. Adjuk meg a húzások számának várható értékét.

Jelentse $X$ a húzások számát, akkor $X$ eloszlása a következő:

$$
P(X=k)=\frac{1}{2} \cdot \frac{2}{3} \cdot \frac{3}{4} \cdots \frac{k-1}{k} \cdot \frac{1}{k+1}=\frac{1}{k(k+1)} \quad k=1,2, \ldots
$$

Tehát az $X$ változó várható értékére az alábbi végtelen sor adódik:

$$
E(X)=\sum_{k=1}^{\infty} k P(X=k)=\sum_{k=1}^{\infty} k \frac{1}{k(k+1)}=\sum_{k=1}^{\infty} \frac{1}{k+1}
$$

Ez utóbbi sor azonban az első tag híján pontosan megegyezik a harmonikus sorral, ami divergens. Tehát ennek a valószínúségi változónak nincs várható értéke.

\subsection{Folytonos eloszlások várható értéke}

17.8 Definíció. Legyen $X$ olyan folytonos eloszlású valószínúségi változó, amelynek sűrűségfüggvénye $f$. Azt mondjuk, hogy az $X$-nek van várható értéke, ha az $\int_{-\infty}^{\infty}|x|$. $f(x) d x$ improprius integrál konvergens, és ekkor az

$$
E(X)=\int_{-\infty}^{\infty} x \cdot f(x) d x
$$

integrál értékét az X várható értékének nevezzük. 
17.9 Példa. Gondoljuk meg például, hogy az alábbi függvény sưrúségfüggvényt definiál

$$
f(x)=\frac{1}{\pi} \cdot \frac{1}{1+x^{2}} \quad-\infty<x<\infty
$$

(ez az úgynevezett Cauchy-eloszlás), de nincs várható értéke, hiszen az

$$
\frac{1}{\pi} \int_{-\infty}^{\infty} \frac{x}{1+x^{2}} d x
$$

improprius integrál divergens.

17.10 Példa. Legyen $[a, b]$ egy adott intervallum a számegyenesen, és tegyük fel, hogy az $X$ valószínúségi változó sưrúségfüggvénye

$$
f(x)= \begin{cases}\frac{1}{b-a} & \text { ha } a<x<b \\ 0 & \text { különben }\end{cases}
$$

Ellenőrizzük, hogy $f$ valóban sûrűségfüggvény! Ekkor az $X$ várható értéke

$$
E(X)=\int_{a}^{b} \frac{x}{b-a} d x=\frac{1}{b-a} \cdot \frac{b^{2}-a^{2}}{2}=\frac{a+b}{2}
$$

ami éppen az $[a, b]$ intervallum felezőpontja.

\subsection{A várható érték tulajdonságai}

Az $X$ változó második momentumának nevezzük az $E\left(X^{2}\right)$ várható értéket (ha ez létezik). Megmutatható, hogy

$$
E\left(X^{2}\right)= \begin{cases}\sum_{k} x_{k}^{2} p_{k} & \text { ha } X \text { diszkrét eloszlású } \\ \int_{-\infty}^{\infty} x^{2} f(x) d x & \text { ha } X \text { folytonos eloszlású }\end{cases}
$$

Az alábbiakban összefoglaljuk a várható érték két fontos tulajdonságát.

\subsection{Tétel.}

1. Ha az $X$ változónak van várható értéke, akkor tetszóleges $\alpha$ és $\beta$ valós számokra $E(\alpha X+\beta)=\alpha E(X)+\beta$.

2. Ha léteznek $E(X), E\left(X^{2}\right)$, úgy $E\left(\alpha X^{2}+\beta X+\gamma\right)=\alpha E\left(X^{2}\right)+\beta E(X)+\gamma$. 
17.12 Példa. Legyen $\lambda$ adott pozitív szám, és tegyük fel, hogy az $X$ valószínûségi változó sûrûségfüggvénye

$$
f(x)= \begin{cases}\lambda e^{-\lambda x} & \text { ha } x>0 \\ 0 & \text { különben. }\end{cases}
$$

A 9.3 Példa alapján ez valóban sűrüségfüggvény, hiszen

$$
\int_{0}^{\infty} f(x) d x=1
$$

másrészt a 9.8 Példa szerint

$$
E(X)=\int_{0}^{\infty} x f(x) d x=\frac{1}{\lambda} .
$$

Ennek a változónak a második momentuma a 9.9 Példa alapján

$$
E\left(X^{2}\right)=\int_{0}^{\infty} x^{2} f(x) d x=\frac{2}{\lambda^{2}} .
$$

\subsection{A variancia és a szórás}

Egy változó varianciáján a várható értéktől mért átlagos négyzetes eltérést értjük.

17.13 Definíció. Az $X$ változó varianciája (ha ez létezik)

$$
\operatorname{Var}(X)=E\left((X-E(X))^{2}\right)
$$

Ekkor az $X$ változó szórása: $D(X)=\sqrt{\operatorname{Var}(X)}$. is.

A variancia helyett néha használatos a szórásnégyzet elnevezés, és a $D^{2}(X)$ jelölés A variancia a következő módon számítható ki egyszerúbb alakban:

$$
\begin{aligned}
\operatorname{Var}(X) & =E\left((X-E(X))^{2}\right)=E\left(X^{2}-2 E(X) X+E(X)^{2}\right) \\
& =E\left(X^{2}\right)-2 E(X)^{2}+E(X)^{2}=E\left(X^{2}\right)-E(X)^{2}
\end{aligned}
$$

Fontos tulajdonságai:

$$
\operatorname{Var}(\alpha X+\beta)=\alpha^{2} \operatorname{Var}(X), \quad D(\alpha X+\beta)=|\alpha| \cdot D(X)
$$


Ellenőrizzük ezeket közvetlenül a definíció alapján.

17.14 Példa. Példaként határozzuk meg adott $\lambda>0$ mellett a 17.12 Példában vizsgált folytonos eloszlású valószínúségi változó varianciáját és szórását.

$$
\operatorname{Var}(X)=E\left(X^{2}\right)-E(X)^{2}=\frac{2}{\lambda^{2}}-\frac{1}{\lambda^{2}}=\frac{1}{\lambda^{2}}
$$

nevezetesen

$$
D(X)=\frac{1}{\lambda}
$$

17.15 Példa. Tekintsük most a 17.10 Példában vizsgált folytonos eloszlású valószínúségi változót. Ennek második momentuma a következőképpen számítható ki:

$$
\begin{aligned}
E\left(X^{2}\right) & =\int_{-\infty}^{\infty} x^{2} f(x) d x=\int_{a}^{b} \frac{x^{2}}{b-a} d x=\frac{1}{b-a}\left[\frac{x^{3}}{3}\right]_{a}^{b} \\
& =\frac{b^{3}-a^{3}}{3(b-a)}=\frac{b^{2}+a b+a^{2}}{3}
\end{aligned}
$$

Tehát a varianciára az alábbi adódik:

$$
\operatorname{Var}(X)=E\left(X^{2}\right)-E(X)^{2}=\frac{b^{2}+a b+a^{2}}{3}-\frac{a^{2}+2 a b+b^{2}}{4}=\frac{(b-a)^{2}}{12}
$$

továbbá az $X$ szórása ennek négyzetgyöke, azaz

$$
D(X)=\frac{b-a}{2 \sqrt{3}} .
$$

\section{Otthoni tanuláshoz}

1. A Feladatgyújtemény-2 IV/2 szakaszának feldolgozása.

2. Házi feladatok: a IV/2 szakasz 351, 352, 354, 355, 358, 361, 369, 374 és 375 feladatai.

3. Tankönyv-2 4.6 és 4.7 szakaszai. 
18.

NEVEZETES DISZKRÉT
ELOSZLÁSOK 

Ebben a fejezetben a gyakorlatban leginkább előforduló diszkrét eloszlások tulajdonságait foglaljuk össze.

\subsection{Karakterisztikus eloszlás}

Legyen $(\Omega, \mathscr{A}, P)$ egy valószínúségi mező és tekintsünk egy $A \in \mathscr{A}$ eseményt, amelyre $P(A)=p$, ahol $0<p<1$. Ekkor az

$$
X= \begin{cases}1 & \text { ha } A \text { bekövetkezik } \\ 0 & \text { ha } A \text { nem következik be }\end{cases}
$$

valószínúségi változó eloszlása

$$
P(X=0)=1-p \quad P(X=1)=p
$$

Ezt az A eseményhez tartozó karakterisztikus eloszlásnak nevezzük. Könnyen ellenőrizhetjük a következő tulajdonságokat.

\subsection{Tétel.}

- Az eloszlás paramétere: $0<p<1$.

- Az eloszlás várható értéke: $E(X)=p$

- Az eloszlás varianciája: $\operatorname{Var}(X)=p(1-p)$.

Bizonyítás. Csak a varianciát kell ellenôriznünk. Mivel a második momentum $E\left(X^{2}\right)=p$, innen azonnal adódik az állítás.

\subsection{Binomiális eloszlás}

Legyen újra $(\Omega, \mathscr{A}, P)$ egy valószínûségi mező és tekintsük a Bernoulli-kísérletet, ahol egymás után $n$ független kísérletet végzünk, amelyek mindegyikében megfigyeljük, hogy egy bizonyos $A$ esemény bekövetkezik-e vagy sem. Tegyük fel, hogy $P(A)=p$, $0<p<1$ adott. Jelentse $X$ az $A$ bekövetkezéseinek számát. A Bernoulli-kísérletról mondottak alapján az $X$ változó eloszlása:

$$
P(X=k)=\left(\begin{array}{l}
n \\
k
\end{array}\right) p^{k}(1-p)^{n-k} \quad k=0,1,2, \ldots, n
$$

ezt az eloszlást binomiális eloszlásnak nevezzük. Tulajdonságai az alábbiak (lásd a 17.4 Példát).

\subsection{Tétel.}


- Az eloszlás paraméterei: $n \in \mathbb{N}$ és $0<p<1$.

- Az eloszlás várható értéke: $E(X)=n p$

- Az eloszlás varianciája: $\operatorname{Var}(X)=n p(1-p)$.

Bizonyítás. Ismét csak a varianciát kell ellenőriznünk. Ehhez meghatározzuk a második momentumot.

$$
\begin{aligned}
E\left(X^{2}\right) & =\sum_{k=1}^{n} k^{2}\left(\begin{array}{l}
n \\
k
\end{array}\right) p^{k}(1-p)^{n-k}= \\
& =\sum_{k=2}^{n} k(k-1)\left(\begin{array}{l}
n \\
k
\end{array}\right) p^{k}(1-p)^{n-k}+\sum_{k=1}^{n} k\left(\begin{array}{l}
n \\
k
\end{array}\right) p^{k}(1-p)^{n-k} \\
& =n(n-1) p^{2} \sum_{k=2}^{n}\left(\begin{array}{l}
n-2 \\
k-2
\end{array}\right) p^{k-2}(1-p)^{n-k}+n p=\left(n^{2}-n\right) p^{2}+n p .
\end{aligned}
$$

Tehát a variancia

$$
\operatorname{Var}(X)=E\left(X^{2}\right)-E(X)^{2}=n(n-1) p^{2}+n p-n^{2} p^{2}=n p(1-p)
$$

ahol felhasználtuk, hogy az első sorban a második szumma éppen a várható érték.

\subsection{Hipergeometriai eloszlás}

Nézzük most a következő visszatevés nélküli mintavételi kísérletet. Tekintsünk egy $N$ számú objektumból álló halmazt, amelyek közül $m$ számú selejtes. Válasszunk ki az egész halmazból véletlenszerúen egy $n$-elemú mintát visszatevés nélkül $(n \leq m)$. Jelentse $X$ a selejtes elemek számát a mintában. Ekkor $X$ eloszlása:

$$
P(X=k)=\frac{\left(\begin{array}{c}
m \\
k
\end{array}\right) \cdot\left(\begin{array}{c}
N-m \\
n-k
\end{array}\right)}{\left(\begin{array}{l}
N \\
n
\end{array}\right)} \quad k=0,1,2, \ldots, n
$$

Ezt az eloszlást hipergeometriai eloszlásnak nevezzük. Ennek tulajdonságait az előző fejezet példája alapján a következő listában foglaljuk össze.

\subsection{Tétel.}

- Az eloszlás paraméterei: $N, m, n \in \mathbb{N}$.

- Az eloszlás várható értéke:

$$
E(X)=n \cdot \frac{m}{N}
$$


- Az eloszlás varianciája:

$$
\operatorname{Var}(X)=\frac{N-n}{N-1} \cdot n \cdot \frac{m}{N}\left(1-\frac{m}{N}\right) .
$$

Bizonyítás. Ismét csak a variancia szorul igazolásra. Számítsuk ki a második momentumot.

$$
\begin{aligned}
E\left(X^{2}\right) & =\sum_{k=1}^{n} k^{2} \frac{\left(\begin{array}{c}
m \\
k
\end{array}\right)\left(\begin{array}{c}
N-m \\
n-k
\end{array}\right)}{\left(\begin{array}{c}
N \\
n
\end{array}\right)}=\sum_{k=2}^{n} k(k-1) \frac{\left(\begin{array}{c}
m \\
k
\end{array}\right)\left(\begin{array}{c}
N-m \\
n-k
\end{array}\right)}{\left(\begin{array}{c}
N \\
n
\end{array}\right)}+\sum_{k=1}^{n} k \frac{\left(\begin{array}{c}
m \\
k
\end{array}\right)\left(\begin{array}{c}
N-m \\
n-k
\end{array}\right)}{\left(\begin{array}{c}
N \\
n
\end{array}\right)} \\
& =\frac{m(m-1) n(n-1)}{N(N-1)} \sum_{k=2}^{n} \frac{\left(\begin{array}{c}
m-2 \\
k-2
\end{array}\right) \cdot\left(\begin{array}{c}
N-m \\
n-k+2
\end{array}\right)}{\left(\begin{array}{c}
N-2 \\
n-2
\end{array}\right)} \\
& =\frac{m(m-1) n(n-1)}{N(N-1)}+n \frac{m}{N} .
\end{aligned}
$$

Innen adódik, hogy

$$
\operatorname{Var}(X)=\frac{m(m-1) n(n-1)}{N(N-1)}+n \frac{m}{N}-n^{2} \frac{m^{2}}{N^{2}}=\frac{N-n}{N-1} \cdot n \cdot \frac{m}{N}\left(1-\frac{m}{N}\right),
$$

amit állítottunk.

\subsection{Geometriai eloszlás}

Tekintsünk újra egy $(\Omega, \mathscr{A}, P)$ valószínúségi mezôt, és benne egy $A$ eseményt, amelyre $P(A)=p$, ahol $0<p<1$ adott. A kísérletet egymás után függetlenül egészen addig ismételten elvégezzük, amíg az $A$ esemény először bekövetkezik. Jelentse $X$ a kísérletek számát. Ekkor $X$ eloszlása:

$$
P(X=k)=(1-p)^{k-1} p \quad k=1,2, \ldots
$$

Ezt az eloszlást geometriai eloszlásnak nevezzük.

\subsection{Tétel.}

- Az eloszlás paramétere: $0<p<1$.

- Az eloszlás várható értéke:

$$
E(X)=\frac{1}{p}
$$

- Az eloszlás varianciája:

$$
\operatorname{Var}(X)=\frac{1-p}{p^{2}}
$$


Bizonyítás. Mivel a várható érték a 17.5 Példa gondolatmenetét követve könnyen adódik, csak a varianciát kell igazolnunk. Esetünkben a második momentum a következő módon számolható ki. A hatványsor második deriváltját használva bármely $|x|<1$ mellett

$$
\sum_{k=2}^{\infty} k(k-1) x^{k-2}=\frac{2}{(1-x)^{3}}
$$

Ezt az azonosságot az $x=1-p$ esetben felhasználva

$$
\begin{aligned}
E\left(X^{2}\right) & =\sum_{k=1}^{\infty} k^{2}(1-p)^{k-1} p=\sum_{k=2}^{\infty} k(k-1)(1-p)^{k-1} p+\sum_{k=1}^{\infty} k(1-p)^{k-1} p \\
& =p(1-p) \sum_{k=1}^{\infty} k(k-1)(1-p)^{k-2}+\frac{1}{p}=\frac{2 p(1-p)}{p^{3}}+\frac{1}{p}
\end{aligned}
$$

Innen azt kapjuk, hogy

$$
\operatorname{Var}(X)=E\left(X^{2}\right)-E(X)^{2}=\frac{2 p(1-p)}{p^{3}}+\frac{1}{p}-\frac{1}{p^{2}}=\frac{1-p}{p^{2}}
$$

amit igazolni akartunk.

\subsection{Poisson-eloszlás}

Tegyük fel, hogy $X$ olyan valószínúségi változó, amelynek értékkészlete $\{0\} \cup \mathbb{N}$ és eloszlása

$$
P(X=k)=\frac{\lambda^{k}}{k !} e^{-\lambda} \quad k=0,1,2, \ldots
$$

ahol $\lambda>0$ adott valós szám.

Nem nehéz belátni, hogy valóban eloszlást definiáltunk, ugyanis

$$
\sum_{k=0}^{\infty} \frac{\lambda^{k}}{k !} e^{-\lambda}=e^{-\lambda} \cdot e^{\lambda}=1
$$

az exponenciális függvény hatványsora alapján. Ezt a végtelen elemú eloszlást Poissoneloszlásnak nevezzük.

\subsection{Tétel.}

- Az eloszlás paramétere: $\lambda>0$.

- Az eloszlás várható értéke: $E(X)=\lambda$,

- Az eloszlás varianciája: $\operatorname{Var}(X)=\lambda$. 
Bizonyítás. A 17.6Példa gondolatmenetét követve ismét csak a variancia szorul igazolásra. Vizsgáljuk meg a második momentumot.

$$
\begin{aligned}
E\left(X^{2}\right) & =\sum_{k=1}^{\infty} k^{2} \frac{\lambda^{k}}{k !} e^{-\lambda} \\
& =\sum_{k=1}^{\infty} k(k-1) \frac{\lambda^{k}}{k !} e^{-\lambda}+\sum_{k=1}^{\infty} k \frac{\lambda^{k}}{k !} e^{-\lambda} \\
& =\lambda^{2} \sum_{k=2}^{\infty} \frac{\lambda^{k-2}}{(k-2) !} e^{-\lambda}+\lambda .
\end{aligned}
$$

Innen a varianciára az adódik, hogy

$$
\operatorname{Var}(X)=E\left(X^{2}\right)-E(X)^{2}=\lambda^{2}+\lambda-\lambda^{2}=\lambda
$$

és ezzel a bizonyítás kész.

Megjegyezzük, hogy a Poisson-eloszlás a binomiális eloszlás "határeloszlásaként" származtatható az alábbi értelemben.

18.6 Tétel. Ha adott $\lambda>0$ és $0<p_{n}<1$ olyan sorozat, amelyre $n p_{n}=\lambda$, akkor

$$
\lim _{n \rightarrow \infty}\left(\begin{array}{l}
n \\
k
\end{array}\right) p_{n}^{k}\left(1-p_{n}\right)^{n-k}=\frac{\lambda^{k}}{k !} e^{-\lambda}
$$

bármely $k=0,1,2, \ldots$ esetén.

Bizonyítás. Valóban, a feltételünk szerint bármely rögzített $k$ index mellett

$$
\begin{aligned}
\left(\begin{array}{l}
n \\
k
\end{array}\right) p_{n}^{k}\left(1-p_{n}\right)^{n-k} & =\left(\begin{array}{l}
n \\
k
\end{array}\right)\left(\frac{\lambda}{n}\right)^{k}\left(1-\frac{\lambda}{n}\right)^{n-k} \\
& =\frac{n(n-1) \ldots(n-k+1)}{n^{k}} \cdot \frac{\lambda^{k}}{k !}\left(1-\frac{\lambda}{n}\right)^{n}\left(1-\frac{\lambda}{n}\right)^{-k}
\end{aligned}
$$

Itt a négy tényező határértékeit egyenként vizsgálva könnyen láthatjuk, hogy azok rendre $1, \lambda^{k} / k !, e^{-\lambda}$ és 1 . Innen már adódik a tétel állítása.

Ez a gyakorlatban azt eredményezi, hogy nagy $n$ értékekre és kicsi $p$ értékekre a binomiális eloszlás jól közelíthető a Poisson-eloszlással,

$$
\left(\begin{array}{l}
n \\
k
\end{array}\right) p_{n}^{k}\left(1-p_{n}\right)^{n-k} \approx \frac{\lambda^{k}}{k !} e^{-\lambda}
$$

bármely $0 \leq k \leq n$ természetes számra.

18.7 Példa. Tegyük fel, hogy annak valószínűsége, hogy egy újonnan gyártott Suzuki Vitara gépkocsiban hibás a légzsák 0.002 egymástól függetlenül. A gyár visszahívást 
rendel el, ha egy adott hónapban legyártott 2000 gépkocsiban legalább 10 esetben hibás a légzsák. Mi a valószínúsége, hogy nem kell visszahívást elrendelni?

Jelölje $X$ a hibás gépkocsik számát egy adott hónapban. Mivel a kísérletünk egy Bernoulli-kísérlet (hiszen a meghibásodás valószínúsége minden autóban 0.002 egymástól függetlenül), ezért $X$ binomiális eloszlású $n=2000$ és $p=0.002$ paraméterekkel. Tehát a keresett valószínúség pontos értéke

$$
P(X \leq 9)=\sum_{k=0}^{9}\left(\begin{array}{c}
2000 \\
k
\end{array}\right) 0.002^{k} 0.998^{2000-k}
$$

amelynek kiszámítása elég reménytelen feladat. Fenti tételünk értelmében azonban közelítő értéket adhatunk a Poisson eloszlás használatával, hiszen " $n$ elég nagy és $p$ elég kicsi", továbbá $\lambda=n p=4$, így

$$
\sum_{k=0}^{9}\left(\begin{array}{c}
2000 \\
k
\end{array}\right) 0.002^{k} 0.998^{2000-k} \approx \sum_{k=0}^{9} \frac{4^{k}}{k !} e^{-4} \approx 0.9919
$$

Ez utóbbi értéket a Poisson-eloszlásra vonatkozó táblázat alapján állapíthatjuk meg, amely a Feladatgyújtemény-2 332-ik oldalán található.

Annak vizsgálata, hogy ez a közelítés mennyire pontos, meghaladja e könyv kereteit.

\section{Otthoni tanuláshoz}

1. A Feladatgyújtemény-2 VI/1, VI/2, VI/3, VI/4, VI/5 és VI/6 szakaszainak feldolgozása.

2. Házi feladatok: a VI/1 szakasz 533, 534, VI/2 szakasz 546, 558, 559, VI/3 szakasz 566, 568, 572, VI/4 szakasz 581, 582, 583, VI/5 szakasz 588, 598, 600, 603, VI/6 szakasz 622, 624, 630 és 632 feladatai. feladatai.

3. Tankönyv-2 4.8 és 4.9 szakaszai. 


\section{9.}

NEVEZETES FOLYTONOS ELOSZLÁSOK 



\subsection{Egyenletes eloszlás}

Legyen $[a, b]$ adott intervallum. Tekintsük azt az $X$ valószínúségi változót, amelynek sûrűségfüggvénye:

$$
f(x)= \begin{cases}\frac{1}{b-a} & \text { ha } a<x<b \\ 0 & \text { különben }\end{cases}
$$

Ekkor az $X$ változót az $[a, b]$ intervallumon egyenletes eloszlásúnak nevezzük. Az elnevezés onnan ered, hogy ilyenkor az $[a, b]$ valamely részintervallumába esés valószínúsége a részintervallum hosszával arányos.

\subsection{Tétel.}

- Az eloszlás paraméterei: $a$ és $b, a<b$.

- Az eloszlás várható értéke:

$$
E(X)=\frac{a+b}{2}
$$

- Az eloszlás varianciája:

$$
\operatorname{Var}(X)=\frac{(b-a)^{2}}{12}
$$

Bizonyítás. Állításaink azonnal következnek a 17.10 és 17.15 Példák eredményiből.

19.2 Példa. Legyen $X$ olyan egyenletes eloszlású változó, amelyre $E(X)=5$ és $\operatorname{Var}(X)=3$. Határozzuk meg a $P(4<X<10)$ valószínúséget!

Az intervallum ismeretlen $a$ és $b$ végpontjaira a feltételek szerint az

$$
\begin{aligned}
\frac{a+b}{2} & =5 \\
\frac{(b-a)^{2}}{12} & =3
\end{aligned}
$$

adódik, amelynek megoldásai $a=2$ és $b=8$. Tehát

$$
P(4<X<10)=P(4<X<8)=\frac{2}{3}
$$

hiszen a $[4,8]$ intervallumon túlnyúló rész 0 valószínúségú. 


\subsection{Exponenciális eloszlás}

Legyen $\lambda>0$ adott valós szám. Tekintsük azt a valószínúségi változót, amelynek sûrûségfüggvénye

$$
f(x)= \begin{cases}\lambda e^{-\lambda x} & \text { ha } x>0 \\ 0 & \text { különben }\end{cases}
$$

Ekkor az $X$ változót exponenciális eloszlásúnak nevezzük. A 9.3Példában elmondottak szerint $f$ valóban sưrűségfüggvény.

\subsection{Tétel.}

- Az eloszlás paraméterei: $\lambda$.

- Az eloszlás várható értéke: $E(X)=1 / \lambda$,

- Az eloszlás varianciája: $\operatorname{Var}(X)=1 / \lambda^{2}$.

Bizonyítás. Tételünk közvetlenül következik a 17.12 és 17.14 Példák egyenlőségeiből.

19.4 Példa. Tekintsünk egy $X$ adott $\lambda>0$-paraméterú exponenciális elsozlású változót. Határozzuk meg a $P(X>E(X))$ valószínúséget!

Mivel tételünk szerint $E(X)=1 / \lambda$, azért

$$
P(X>E(X))=P\left(X>\frac{1}{\lambda}\right)=\int_{1 / \lambda}^{\infty} \lambda e^{-\lambda x} d x=\left[-e^{-\lambda x}\right]_{1 / \lambda}^{\infty}=\frac{1}{e} .
$$

Az exponenciális eloszlást memória nélkülinek nevezzük az alábbi értelemben. Ha $X$ valamely $\lambda$-paraméterú exponenciális eloszlású változó, továbbá $t, s>0$ tetszőlegesek, akkor

$$
P(X>t+s \mid X>t)=P(X>s) .
$$

Valóban, az $\{X>t+s\}$ eseményből következik $\{X>t\}$, ezért a bal oldalon álló feltételes valószínúség a következőképpen írható

$$
\begin{aligned}
P(X>t+s \mid X>t) & =\frac{P(X>t+s)}{P(X>t)}=\frac{1-\int_{0}^{t+s} e^{-\lambda x} d x}{1-\int_{0}^{t} e^{-\lambda x} d x} \\
& =\frac{e^{-\lambda(t+s)}}{e^{-\lambda t}}=e^{-\lambda s}=1-\int_{0}^{s} e^{-\lambda x} d x=P(X>s) .
\end{aligned}
$$

Ha például $X$ a várakozási idôt jelenti két bekövetkezés (pl. két telefonhívás, vagy két ügyfél, stb) között, akkor a memória-nélküliség azt jelenti, hogy a további várokozás ideje nem függ attól, hogy előzetesen mennyit vártunk. 
Fordítva, az is igazolható, hogy ha egy folytonos eloszlás memória nélküli, akkor az szükségképpen az exponenciális eloszlás valamilyen $\lambda>0$ paraméterrel.

Érdekes kapcsolat van a Poisson-eloszlás és az exponenciális eloszlás között. Nevezetesen, ha egy intervallumban egy véletlen esemény bekövetkezéseinek száma Poisson-eloszlású, akkor a bekövetkezések közötti követési távolság exponenciális eloszlású ugyanazon paraméterrel. Ennek az állításnak a megfordítása is érvényes. Ezekkel a kérdésekkel a 22. fejezetben foglalkozunk részletesebben.

\subsection{A standard normális eloszlás}

A standard normális eloszlás centrális jelentősége miatt a valószínúségi változóra, annak sûrúség, illetve eloszlásfüggvényére külön jelölést használunk.

19.5 Definíció. Azt mondjuk, hogy a $Z$ valószínűségi változó standard normális eloszlású, ha a sưrűségfüggvénye

$$
\varphi(x)=\frac{1}{\sqrt{2 \pi}} e^{-\frac{x^{2}}{2}} \quad-\infty<x<\infty
$$

A 9.2 egyenlőség mutatja, hogy $\varphi$ valóban sűrűségfüggvényt definiál. Gyakorlásképpen vizsgáljuk meg a $\varphi$ függvényt, és mutassuk meg, hogy rendelkezik a következő tulajdonságokkal.

$$
\lim _{x \rightarrow-\infty} \varphi(x)=\lim _{x \rightarrow+\infty} \varphi(x)=0
$$

továbbá $\varphi$ szigorúan monoton növő a $(-\infty, 0)$ intervallumon, szigorúan monoton fogyó a $(0, \infty)$ intervallumon, és globális maximuma van az $x=0$ helyen.

A második derivált vizsgálata alapján $\varphi$ konvex a $(-\infty, 1)$ és $(1,+\infty)$ intervallumokon, valamint konkáv a $(-1,1)$ intervallumon, és inflexiós pontjai vannak az $x=-1$ és $x=1$ pontokban. KÉSZÍTSÜNK ÁBRÁT! 


\subsection{Tétel.}

- Az eloszlás paraméterei: nincs paraméter,

- Az eloszlás várható értéke: $E(Z)=0$,

- Az eloszlás varianciája: $\operatorname{Var}(Z)=1$.

Bizonyítás. A 9.6 Példa szerint egyrészt $E(Z)=0$, másrészt a 9.3 egyenlőség alapján a második momentum $E\left(Z^{2}\right)=1$. Tehát

$$
\operatorname{Var}(Z)=E\left(Z^{2}\right)-E(Z)^{2}=1 .
$$

amit igazolnunk kellett.

Jelölje a továbbiakban $\Phi$ a standard normális eloszlásfüggvényt, azaz

$$
\Phi(x)=\int_{-\infty}^{x} \varphi(t) d t
$$

Ez a függvény rendelkezik az eloszlásfüggvények tulajdonságaival, de érdekessége, hogy nem lehet elemi függvényekkel, vagy azok véges kombinációival explicit alakban előállítani.

FIGYELEM! Lásd a 9. fejezetben mondottakat a $\varphi$ primitív függvényérôl!

Vegyük észre, hogy $\varphi$ páros függvény, azaz szimmetrikus az y-tengelyre. Ebből adódik, hogy $\Phi(0)=1 / 2$, valamint

$$
\Phi(-x)=1-\Phi(x)
$$

bármely $x$ valós számra.

19.7 Példa. A statisztikában és további alkalmazásokban betöltött központi szerepe miatt a $\Phi$ eloszlásfüggény étékeire táblázatokat találhatunk a legtöbb valószínúségszámítással foglalkozó tankönyvben, illetve feladatgyưjteményben, továbbá a táblázatkezelő programokban, mint például az MS Windows Office Excel alkalmazásban is. Lásd a Feladatgyûjtemény-2 338-339-ik oldalain található táblázatokat!

Ha például $Z$ standard normális eloszlású valószínúségi változó, úgy határozzuk meg a

$$
P(-2<Z<2)
$$

valószínúséget. A Feladatgyújtemény-2 339-ik oldalán található táblázatot használva

$$
\begin{aligned}
P(-2<Z<2) & =\Phi(2)-\Phi(-2)=\Phi(2)-(1-\Phi(2))=2 \Phi(2)-1= \\
& =2 \cdot 0.9772-1=0.9544
\end{aligned}
$$

ahol kihasználtuk a 19.1 alatti szimmetriatulajdonságot is. 


\subsection{Normális eloszlás}

19.8 Definíció. Legyenek $m$ és $\sigma$ adott valós számok, ahol $\sigma>0$. Legyen $Z$ standard normális eloszlású változó, ekkor az

$$
X=\sigma Z+m
$$

valószínúségi változót $(m, \sigma)$-paraméterü normális eloszlásúnak nevezzük.

A standard normális eloszlás, valamint a várható érték és szórás tulajdonságaiból (lásd a 17.11 Tételt) adódnak az $(m, \sigma)$-paraméterû normális eloszlású $X$ változó tulajdonságai.

\subsection{Tétel.}

- Az eloszlás paraméterei: $m, \sigma>0$.

- Az eloszlás várható értéke: $E(X)=m$,

- Az eloszlás varianciája: $\operatorname{Var}(X)=\sigma^{2}$.

Vajon hogyan állíthatjuk elő ennek az $X$ változónak az eloszlás, és sűrûségfüggvényét? Jelölje $F$ az $X$ eloszlásfüggvényét, és legyen $x$ tetszőleges valós szám. Ekkor

$$
F(x)=P(X<x)=P(\sigma Z+m<x)=P\left(Z<\frac{x-m}{\sigma}\right)=\Phi\left(\frac{x-m}{\sigma}\right)
$$

FIGYELEM! Fontos, hogy $\sigma>0$, hiszen így pozitív számmal osztunk, ezért az egyenlőtlenség iránya nem változik.

Az $X$ változó $f$ sûrûségfüggvényét deriválással kapjuk: bármely $x \in \mathbb{R}$ esetén

$$
f(x)=F^{\prime}(x)=\frac{1}{\sigma} \varphi\left(\frac{x-m}{\sigma}\right)=\frac{1}{\sqrt{2 \pi} \sigma} e^{-\frac{(x-m)^{2}}{2 \sigma^{2}}}
$$

a láncszabály alapján. Ennek a függvénynek globális maximumhelye van az $x=m$ pontban, továbbá inflexiós pontjai vannak az $x=m-\sigma$ és $x=m+\sigma$ helyeken. KÉSZÍTSÜNK ÁBRÁT!

19.10 Példa. Egy $(m, \sigma)$-paraméterû normális eloszlású $X$ változó esetén valamely intervallumba esés valószínűsége mindig kifejezhető a $\Phi$ eloszlásfüggvénnyel. 
Legyenek ugyanis $a<b$ tetszőleges valós számok. Ekkor

$$
P(a<X<b)=F(b)-F(a)=\Phi\left(\frac{b-m}{\sigma}\right)-\Phi\left(\frac{a-m}{\sigma}\right) .
$$

Például egy $m=10, \sigma=2$ paraméterekkel rendelkező $X$ normális eloszlású változóra

$$
\begin{aligned}
P(7<X<13) & =F(13)-F(7)=\Phi(1.5)-\Phi(-1.5)=2 \Phi(1.5)-1= \\
& =2 \cdot 0.9332-1=0.8664
\end{aligned}
$$

ahol felhasználtuk $\Phi$ szimmetriáját, és a Feladatgyújtemény-2 339-ik oldalán található táblázatot is.

\section{Otthoni tanuláshoz}

1. A Feladatgyújtemény-2 VI/1, VI/2, VI/3, VI/4, VI/5 és VI/6 szakaszainak feldolgozása.

2. Házi feladatok: a VI/1 szakasz 533, 534, VI/2 szakasz 546, 558, 559, VI/3 szakasz 566, 568, 572, VI/4 szakasz 581, 582, 583, VI/5 szakasz 588, 598, 600, 603, VI/6 szakasz 622, 624, 630 és 632 feladatai. feladatai.

3. Tankönyv-2 4.8 és 4.9 szakaszai. 



\subsection{Együttes eloszlásfüggvény}

20.1 Definíció. Legyenek $X$ és $Y$ valószínúségi változók (nem feltételenül ugyanazon az eseménytéren). Tetszőleges $x$ és $y$ valós számokra az

$$
F(x, y)=P(X<x, Y<y)
$$

függvényt az $X$ és $Y$ együttes eloszlásfüggvényének nevezzük.

A definícióból adódik a következő állítás.

20.2 Állítás. Ha F együttes eloszlásfüggvény, akkor

$$
\lim _{x \rightarrow-\infty} F(x, y)=\lim _{y \rightarrow-\infty} F(x, y)=0
$$

bármely rögzített y illetve $x$ valós szám mellett, továbbá

$$
\lim _{x, y \rightarrow+\infty} F(x, y)=1
$$

Az egydimenziós esethez hasonlóan itt is külön foglalkozunk a diszkrét és a folytonos eloszlásokkal.

\subsection{Diszkrét együttes eloszlások}

20.3 Definíció. Tegyük fel, hogy az $X$ változó értékkészlete $\left\{x_{1}, x_{2}, \ldots\right\}$, illetve az $Y$ változó értékkészlete $\left\{y_{1}, y_{2}, \ldots\right\}$. Ekkor $X$ és $Y$ együttes eloszlása

$$
p_{i k}=P\left(X=x_{i}, Y=y_{k}\right) \quad i=1,2, \ldots \quad k=1,2, \ldots
$$

Ezeket az értékeket a következő táblázattal adhatjuk meg:

\begin{tabular}{c|cccc}
$y \backslash x$ & $x_{1}$ & $x_{2}$ & $x_{3}$ & $\cdots$ \\
\hline$y_{1}$ & $p_{11}$ & $p_{21}$ & $p_{31}$ & $\cdots$ \\
$y_{2}$ & $p_{12}$ & $p_{22}$ & $p_{32}$ & $\cdots$ \\
$y_{3}$ & $p_{13}$ & $p_{23}$ & $p_{33}$ & $\cdots$ \\
$\vdots$ & $\vdots$ & $\vdots$ & $\vdots$ & $\vdots$
\end{tabular}


Világos, hogy mindegyik $p_{i k} \geq 0$ és $\sum_{i} \sum_{k} p_{i k}=1$.

Legyen $A$ a sík valamely részhalmaza. Vajon hogyan határozhatjuk meg a $P((X, Y) \in$ $A$ ) valószínúséget? Gyújtsük össze mindazon $x_{i}$ és $y_{k}$ értékeket, amelyekre $\left(x_{i}, y_{k}\right) \in A$, ekkor

$$
P((X, Y) \in A)=\sum_{\left(x_{i}, y_{k}\right) \in A} p_{i k}
$$

20.4 Példa. Például az alábbi együttes eloszlás esetén

\begin{tabular}{c|cccc}
$y \backslash x$ & 0 & 1 & 2 & 3 \\
\hline 0 & 0.1 & 0.08 & 0.13 & 0.04 \\
1 & 0.04 & 0.2 & 0.08 & 0 \\
2 & 0.03 & 0 & 0.05 & 0.25
\end{tabular}

az $A=\left\{(x, y) \in \mathbb{R}^{2}: x+y \geq 3\right\}$ tartományba esés valószínúsége:

$$
P(X+Y \geq 3)=0.04+0.08+0.05+0.25=0.42
$$

Felmerül a kérdés, hogy az együttes eloszlás ismeretében hogyan határozható meg $X$ és $Y$ eloszlása? A definícióból látható, hogy

$$
p_{i}=P\left(X=x_{i}\right)=\sum_{k} p_{i k}=\sum_{k} P\left(X=x_{i}, Y=y_{k}\right) \quad i=1,2, \ldots
$$

Nevezetesen a $p_{i}=P\left(X=x_{i}\right)$ valószínúség az $i$-ik oszlop elemeinek összegeként nyerhetô. Tehát az oszlopösszegek az $X$ változó eloszlását adják.

Teljesen analóg módon

$$
q_{k}=P\left(Y=x_{k}\right)=\sum_{i} p_{i k}=\sum_{i} P\left(X=x_{i}, Y=y_{k}\right) \quad k=1,2, \ldots
$$

azaz $Y$ eloszlása a sorok összegeként kapható.

20.5 Definíció. $X$ és $Y$ eloszlásait az együttes eloszlás peremeloszlásainak nevezzük.

\subsection{Folytonos együttes eloszlások}

20.6 Definíció. Azt mondjuk, hogy $X$ és $Y$ együttes eloszása folytonos, ha létezik olyan $f$ nemnegatív integrálható függvény a síkon, amelyre minden $x$ és $y$ valós számok mellett

$$
F(x, y)=\int_{-\infty}^{x} \int_{-\infty}^{y} f(t, s) d s d t
$$

ahol $F$ az $X$ és $Y$ valószínúségi változók együttes eloszlásfüggvénye. Ezt az $f$ függvényt az $X$ és $Y$ együttes súrüségfüggvényének nevezzük. 
Világos, hogy ha $f$ együttes sûrűségfüggvény, akkor nemnegatív a síkon, továbbá

$$
\int_{-\infty}^{\infty} \int_{-\infty}^{\infty} f(x, y) d x d y=1
$$

20.7 Példa. Legyen $A$ a sík valamely részhalmaza. Hogyan határozható meg a $P((X, Y) \in A)$ valószínúség? Ha $f$ az $X$ és $Y$ együttes sûrúségfüggvénye, akkor

$$
P((X, Y) \in A)=\iint_{A} f(x, y) d y d x
$$

Például az alábbi együttes sưrűségfüggvény esetében

$$
f(x, y)= \begin{cases}\frac{2}{3}(x+2 y) & \text { ha } 0<x<1,0<y<1 \\ 0 & \text { különben }\end{cases}
$$

az $A=\left\{(x, y) \in \mathbb{R}^{2}: x<1 / 2, y<1 / 2\right\}$ tartományba esés valószínúsége

$$
P(X<1 / 2, Y<1 / 2)=\frac{2}{3} \int_{0}^{1 / 2} \int_{0}^{1 / 2}(x+2 y) d y d x=\frac{1}{8}
$$

Felmerül a kérdés, hogy az együttes sûrúségfüggvény ismeretében hogyan határozható meg $X$ és $Y$ sưrúségfüggvénye? Belátható, hogy ha $f_{X}$ az $X$ súrúségfüggvénye, akkor minden $x$ pontban

$$
f_{X}(x)=\int_{-\infty}^{\infty} f(x, y) d y
$$

és teljesen analóg módon

$$
f_{Y}(y)=\int_{-\infty}^{\infty} f(x, y) d x
$$

bármely $x$ és $y$ pontokban.

20.8 Definíció. Az $f_{X}$ és $f_{Y}$ függvényeket az együttes eloszlás peremsûrüségfüggvényeinek nevezzük.

20.9 Példa. Például az elôző példában vizsgált együttes sưrűségfüggvény esetén

$$
f_{X}(x)=\int_{-\infty}^{\infty} f(x, y) d y= \begin{cases}\int_{0}^{1} \frac{2}{3}(x+2 y) d y & \text { ha } 0<x<1 \\ 0 & \text { különben }\end{cases}
$$

Analóg módon állítható elő az $Y$ peremsűrúségfüggvénye:

$$
f_{Y}(y)= \begin{cases}\frac{1}{3}(4 y+1) & \text { ha } 0<y<1 \\ 0 & \text { különben }\end{cases}
$$




\subsection{Függetlenség}

20.10 Definíció. Legyenek $X$ és $Y$ valószínúségi változók, amelyek együttes eloszlásfüggvénye $F$. Jelölje $F_{X}$ illetve $F_{Y}$ az $X$ illetve az $Y$ eloszlásfüggvényét. Azt mondjuk, hogy $X$ és $Y$ függetlenek, ha

$$
F(x, y)=F_{X}(x) \cdot F_{Y}(y)
$$

bármely $x, y$ valós számokra.

A definíciónk úgy is megfogalmazható, hogy $X$ és $Y$ függetlenek, ha

$$
P(X<x, Y<y)=P(X<x) \cdot P(Y<y)
$$

tetszőleges $x, y$ valós számokra. Ennek a definíciónak könnyen ellenőrizhető ekvivalens alakjait fogalmazzuk meg az alábbiakban diszkrét illetve folytonos eloszlásokra

Legyenek $X$ és $Y$ diszkrét valószínúségi változók, amelyek együttes eloszlása

$$
P\left(X=x_{i}, Y=y_{k}\right)=p_{i k} \quad i=1,2, \ldots \quad k=1,2, \ldots
$$

Tekintsük az $X$ és $Y$ peremeloszlásait:

$$
P\left(X=x_{i}\right)=p_{i} \quad i=1,2, \ldots \quad P\left(Y=y_{k}\right)=q_{k} \quad k=1,2, \ldots
$$

20.11 Tétel. $X$ és $Y$ akkor és csak akkor függetlenek, ha

$$
p_{i k}=p_{i} \cdot q_{k}
$$

minden i és $k$ indexekre.

Tételünk azt fogalmazza meg, hogy független változókra az együttes eloszlás a peremeloszlások szorzataként áll elő. Például a 20.4 Példában szereplő változók nem függetlenek, hiszen rögtön az együttes eloszlás első elemére

$$
0.17 \cdot 0.35=p_{1} \cdot q_{1} \neq p_{11}=0.1,
$$

ellenőrizzük!

Legyenek most $X$ és $Y$ folytonos eloszlású változók, amelyek együttes sűrűségfüggvénye $f$. Jelölje $f_{X}$ az $X$, illetve $f_{Y}$ az $Y$ peremsưrüségfüggvényét.

20.12 Tétel. $X$ és $Y$ akkor és csak akkor függetlenek, ha bármely x és y valós számokra

$$
f(x, y)=f_{X}(x) \cdot f_{Y}(y)
$$


Bizonyítás. Könnyen adódik az $F(x, y)=F_{X}(x) \cdot F_{Y}(y)$ egyenlőségből.

20.13 Példa. Például a 20.1 alatti példában szereplő változók nem függetlenek, hiszen

$$
f_{X}(x) \cdot f_{Y}(y) \neq f(x, y),
$$

azaz a peremsűrűségfüggvények szorzata nem állítja elő az együttes sûrûségfüggvényt.

Könnyen látható azonban, hogy ha $X$ és $Y$ együttes sûrúségfüggvénye

$$
f(x, y)= \begin{cases}4 x y & \text { ha } 0<x<1,0<y<1 \\ 0 & \text { különben }\end{cases}
$$

akkor $X$ és $Y$ függetlenek. Valóban, ekkor

$$
f_{X}(x)=\int_{-\infty}^{\infty} f(x, y) d y=\int_{0}^{1} 4 x y d y= \begin{cases}2 x & \text { ha } 0<x<1 \\ 0 & \text { különben } .\end{cases}
$$

és $f$ szimmetriája miatt $f_{Y}$ ugyanilyen alakú az y változóban. Ezért

$$
f(x, y)=f_{X}(x) \cdot f_{Y}(y)
$$

minden $x$ és $y$ valós számra.

\subsection{Feltételes eloszlások}

Tekintsük az $X$ és $Y$ diszkrét valószínúségi változókat, amelyek együttes eloszlása $P\left(X=x_{i}, Y=y_{k}\right)=p_{i k}$, ahol $i=1,2, \ldots$ és $k=1,2, \ldots$

20.14 Definíció. Tegyük fel, hogy valamely $k$ indexre $P\left(Y=y_{k}\right)>0$. Ekkor $X$ feltételes eloszlásán az $Y=y_{k}$ feltétel mellett a

$$
P\left(X=x_{i} \mid Y=y_{k}\right)=\frac{P\left(X=x_{i}, Y=y_{k}\right)}{P\left(Y=y_{k}\right)}, \quad i=1,2, \ldots
$$

eloszlást értjük.

FIGYELEM! Ellenôrizzük közvetlenül a definíció alapján, hogy valóban eloszlást definiáltunk.

20.15 Definíció. Az $X$ változó feltételes várható értékén az $Y=y_{k}$ feltétel mellett az

$$
E\left(X \mid Y=y_{k}\right)=\sum_{i=1} x_{i} \cdot P\left(X=x_{i} \mid Y=y_{k}\right)
$$

szummát értjük, amely véges vagy végtelen aszerint, hogy $X$ értékkészlete véges vagy végtelen, ezért nem jelöltük a felső határt. 
20.16 Példa. Tekintsük például a 20.4 Példában megadott együttes eloszlást. Ekkor $P(Y=1)=0.32$, továbbá az $X$ feltételes várható értéke az $Y=1$ feltétel mellett

$$
E(X \mid Y=1)=0 \cdot 0.04+1 \cdot 0.2+2 \cdot 0.08+3 \cdot 0=0.36
$$

\section{Otthoni tanuláshoz}

1. A Feladatgyújtemény-2 V/1 és V/2 szakaszainak feldolgozása.

2. Házi feladatok: az V/1 szakasz 411, 412, 417, 420, 424 és 427, valamint az V/2 szakasz 435, 437 és 438 feladatai.

3. Tankönyv-2 6.1, 6.2, 6.3, 6.4, 6.5, 6.6 és 6.7 szakaszai. 


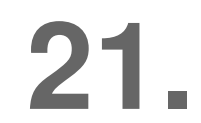

KOVARIANCIA ÉS KORRELÁCIÓ 



\section{1. Összeg várható értéke}

21.1 Tétel. Ha az $X$ és $Y$ változóknak van várható értéke, akkor $X+Y$-nak is, és

$$
E(X+Y)=E(X)+E(Y)
$$

Bizonyítás. Diszkrét esetben vázoljuk a bizonyítást, a folytonos esetben analóg módon megy.

$$
\begin{aligned}
E(X+Y) & =\sum_{i} \sum_{k}\left(x_{i}+y_{k}\right) P\left(X=x_{i}, Y=y_{k}\right) \\
& =\sum_{i} x_{i} \sum_{k} p_{i k}+\sum_{k} y_{k} \sum_{i} p_{i k} \\
& =\sum_{i} x_{i} P\left(X=x_{i}\right)+\sum_{k} y_{k} P\left(Y=y_{k}\right)=E(X)+E(Y)
\end{aligned}
$$

Tételünk természetesen tetszőleges véges összegre is érvényes marad.

21.2 Példa. Tegyük fel, hogy $n$ számú papírlapra felírtuk egyenként az $1, \ldots, n$ számokat, majd a lapokat egy kalapba tettük. Találomra egymás után, visszatevéssel kiveszünk $m$ számú lapot. Jelentse $X$ a húzott számok összegét. Mennyi $E(X)$ ?

Kipróbálhatjuk, hogy $X$ eloszlását igen komplikált előállítani.

Jelentsék $X_{1}, \ldots, X_{m}$ rendre a kihúzott számokat. A visszatevéses mintavétel miatt mindegyik $X_{k}$ azonos eloszlású, nevezetesen

$$
P\left(X_{k}=i\right)=\frac{1}{n} \quad i=1, \ldots, n
$$

Ez azt jelenti, hogy

$$
E\left(X_{k}\right)=\sum_{i=1}^{n} i \cdot \frac{1}{n}=\frac{n(n+1)}{2} \cdot \frac{1}{n}=\frac{n+1}{2} .
$$

Másrészt nyilván $X=X_{1}+\ldots+X_{m}$, ezért

$$
E(X)=E\left(X_{1}\right)+\ldots+E\left(X_{m}\right)=m \cdot \frac{n+1}{2}
$$

Tehát $E(X)$ megadható az $X$ eloszlásának ismerete nélkül is! 


\subsection{Szorzat várható értéke}

Ha $X$ és $Y$ diszkrét változók, amelyeknek van várható értékük, akkor

$$
E(X Y)=\sum_{i} \sum_{k} x_{i} y_{k} \cdot p_{i k}
$$

ahol $X$ értékkészlete $\left\{x_{1}, x_{2}, \ldots\right\}, Y$ értékkészlete $\left\{y_{1}, y_{2}, \ldots\right\}$ és $p_{i k}$ jelöli az együttes eloszlást.

Teljesen analóg módon, ha $X$ és $Y$ folytonos eloszlású változók, amelyeknek létezik várható értékük, és együttes sûrûségfüggvényük $f$, akkor

$$
E(X Y)=\int_{-\infty}^{\infty} \int_{-\infty}^{\infty} x y \cdot f(x, y) d x d y
$$

21.3 Tétel. Ha X és $Y$ függetlenek, akkor

$$
E(X Y)=E(X) \cdot E(Y)
$$

Bizonyítás. Vizsgáljuk meg a folytonos esetet, a diszkrét eset ugyanígy megy.

$$
\begin{aligned}
E(X Y) & =\int_{-\infty}^{\infty} \int_{-\infty}^{\infty} x y \cdot f(x, y) d x d y=\int_{-\infty}^{\infty} \int_{-\infty}^{\infty} x y \cdot f_{X}(x) \cdot f_{Y}(y) d x d y \\
& =\int_{-\infty}^{\infty} x f_{X}(x) d x \cdot \int_{-\infty}^{\infty} y f_{Y}(y) d y=E(X) \cdot E(Y)
\end{aligned}
$$

ugyanis a függetlenség miatt az együttes sűrúségfüggvény az $f(x, y)=f_{X}(x) \cdot f_{Y}(y)$ szorzat alakban áll elő.

\section{3. Összeg varianciája}

21.4 Tétel. Tegyük fel, hogy X és Y függetlenek, és mindkettőnek van varianciája. Akkor

$$
\operatorname{Var}(X+Y)=\operatorname{Var}(X)+\operatorname{Var}(Y)
$$

Az állitás tetszóleges véges összegre is érvényes. 
Bizonyítás. Valóban, a szorzat várható értékére vonatkozó tételünk alapján:

$$
\begin{aligned}
\operatorname{Var}(X+Y)= & E\left((X+Y-E(X+Y))^{2}\right) \\
= & E\left((X-E(X))^{2}\right)+E\left((Y-E(Y))^{2}\right) \\
& +2 E((X-E(X))(Y-E(Y))) \\
= & \operatorname{Var}(X)+\operatorname{Var}(Y)+2(E(X Y)-E(X) E(Y)) \\
= & \operatorname{Var}(X)+\operatorname{Var}(Y) .
\end{aligned}
$$

21.5 Példa. Vajon miért gondoljuk, hogy egy kísérlet többszöri elvégzésekor az eredmények átlagolásával várhatóan pontosabb eredményt kapunk?

Tegyük fel, hogy egy ismeretlen $m$ mennyiség meghatározására $n$ számú megfigyelést végzünk, amelyeknek eredményei $X_{1}, \ldots, X_{n}$ valószínúségi változók. Feltesszük, hogy a változók függetlenek, és azonos eloszlásúak, amelyekre

$$
E\left(X_{k}\right)=m, \quad D\left(X_{k}\right)=\sigma, \quad k=1,2, \ldots, n .
$$

Az a feltevésünk, hogy a változók azonos eloszlásúak, azt jelenti, hogy a megfigyeléseket (méréseket) azonos körülmények között végezzük. Ilyenkor $\sigma$ jelenti a várható hibát. Átlagoljuk az eredményeinket, azaz vezessük be az

$$
Y_{n}=\frac{X_{1}+\ldots+X_{n}}{n}
$$

valószínúségi változót. Ekkor világos, hogy $E\left(Y_{n}\right)=m$, továbbá a fenti tételünk értelmében

$$
\operatorname{Var}\left(Y_{n}\right)=\operatorname{Var}\left(\frac{1}{n}\left(X_{1}+\ldots+X_{n}\right)\right)=\frac{1}{n^{2}} n \cdot \sigma^{2}=\frac{\sigma^{2}}{n} .
$$

a függetlenség miatt. Innen az $Y_{n}$ szórására az adódik, hogy

$$
D\left(Y_{n}\right)=\frac{\sigma}{\sqrt{n}}
$$

tehát $n \rightarrow \infty$ esetén $D\left(Y_{n}\right) \rightarrow 0$, azaz az $n$ növelésével a várható hiba nullához tart.

\subsection{Kovariancia és korreláció}

Valószínúségi változók közötti összefüggés mérésére használjuk az alábbi fogalmakat.

21.6 Definíció. Az $X$ és $Y$ változók kovarianciája

$$
\operatorname{Cov}(X, Y)=E((X-E(X)) \cdot(Y-E(Y)))
$$


és korrelációs együtthatója

$$
\operatorname{Corr}(X, Y)=\frac{\operatorname{Cov}(X, Y)}{D(X) \cdot D(Y)}
$$

Könnyen látható, hogy

$$
\operatorname{Cov}(X, Y)=E(X Y-E(X) Y-E(Y) X+E(X) E(Y))=E(X Y)-E(X) E(Y),
$$

és általában ezt az egyszerúbb kifejezést használjuk a kovariancia meghatározására.

Megjegyezzük, hogy a kovariancia nem ad abszolút mérőszámot az összefüggés mérésére, hiszen bármely $\alpha \neq 0$ valós szám esetén

$$
\operatorname{Cov}(\alpha X, Y)=\alpha \operatorname{Cov}(X, Y)
$$

azaz a mérték függ a dimenziótól. Gondoljunk arra, hogy ha $X$ és $Y$ egy feladatban Euróban számított költségeket jelentenek, akkor Forintra áttérve a kovariancia kb. $310^{2}$ szeresére változik. A korrelációs együttható azonban már független a dimenziótól, hiszen bármely $\alpha \neq 0$ és $\beta$ valós számokra

$$
\operatorname{Corr}(\alpha X+\beta, \alpha Y+\beta)=\operatorname{Corr}(X, Y)
$$

azaz a korreláció invariáns a lineáris transzformációra. FIGYELEM! Ellenőrizzük ezt az egyenlőséget közvetlenül a definíció alapján!

\subsection{Tétel.}

$$
\text { 1. }-1 \leq \operatorname{Corr}(X, Y) \leq 1
$$

2. Ha X és $Y$ függetlenek, akkor $\operatorname{Cov}(X, Y)=0$

Bizonyítás. Az elsô állítás bizonyításához legyen $t \in \mathbb{R}$ tetszőleges, és tekintsük a

$$
W=[X-E(X)+t(Y-E(Y))]^{2}
$$

valószínűségi változót. Mivel $W$ nemnegatív, ezért várható értéke is nemnegatív. Ez azt jelenti, hogy

$$
E(W)=E\left((X-E(X))^{2}\right)+2 t \operatorname{Cov}(X, Y)+t^{2} E\left((Y-E(Y))^{2}\right) \geq 0
$$

minden $t$ valós számra. Ez a kifejezés $t$-ben másodfokú, ezért csak úgy lehet nemnegatív, ha a diszkriminánsa nempozitív. Tehát

$$
4 \operatorname{Cov}(X, Y)^{2}-4 E\left((X-E(X))^{2}\right) E\left((Y-E(Y))^{2}\right) \leq 0 .
$$

A jobb oldalon éppen a varianciák szorzata áll. Rendezve és mindkét oldalból négyzetgyököt vonva azt kapjuk, hogy

$$
|\operatorname{Cov}(X, Y)| \leq D(X) D(Y)
$$

amiből azonnal következik az állítás. 
A második állításunk a 21.3 Tétel közvetlen következménye.

21.8 Példa. FIGYELEM! Az alábbi példánk mutatja, hogy a tételünk második állítása nem fordítható meg. Feldobunk egymás után két érmét és legyen

$$
X_{k}=\left\{\begin{array}{cc}
0 & \text { ha a } k \text {-ik dobás fej } \\
1 & \text { ha a } k \text {-ik dobás írás }
\end{array}\right.
$$

$(k=1,2)$. Tekintsük az $Y_{1}=X_{1}+X_{2}$ és $Y_{2}=X_{1}-X_{2}$. változókat. Ekkor

\begin{tabular}{r|ccc}
$Y_{2} \backslash Y_{1}$ & 0 & 1 & 2 \\
\hline-1 & 0 & 0.25 & 0 \\
0 & 0.25 & 0 & 0.25 \\
1 & 0 & 0.25 & 0
\end{tabular}

Az együttes eloszlás vizsgálatával látható, hogy $Y_{1}$ és $Y_{2}$ nem függetlenek, de könnyen kiszámolható, hogy $\operatorname{Cov}\left(Y_{1}, Y_{2}\right)=0$

\subsection{Teljes várható érték tétel}

Tekintsük az $X$ és $Y$ diszkrét változókat, amelyek együttes eloszlása $P\left(X=x_{i}, Y=\right.$ $\left.y_{k}\right)=p_{i k}$ és $P\left(Y=y_{k}\right)>0$ az $i=1,2, \ldots$ és $k=1,2 \ldots$ indexekre.

21.9 Definíció. Képezzük az $X$ feltételes várható értékeit az $Y=y_{k}$ feltételek mellett, azaz

$$
m_{k}=E\left(X \mid Y=y_{k}\right)=\sum_{i=1} x_{i} P\left(X=x_{i} \mid Y=y_{k}\right)
$$

minden $k=1,2 \ldots$ esetén. Ezt a sorozatot az $X$ változó $Y$-ra vonatkozó feltételes várható értékének nevezzük. Jelölése $E(X \mid Y)$.

Vegyük észre, hogy itt egy valószínúségi változót definiáltunk, nevezetesen

$$
E(X \mid Y)=m_{k}, \quad \text { ha } Y=y_{k}, k=1,2, \ldots
$$

Az alábbiakban megadjuk ennek a változónak a várható értékét. Ezt az eredményünket a Teljes valószínúség tétel általánosításának tekinthetjük.

21.10 Tétel. (Teljes várható érték tétel) $E(E(X \mid Y))=E(X)$.

Bizonyítás. Valóban,

$$
\begin{aligned}
E(E(X \mid Y)) & =\sum_{k=1} m_{k} P\left(Y=y_{k}\right)=\sum_{k=1} \sum_{i=1} x_{i} P\left(X=x_{i} \mid Y=y_{k}\right) P\left(Y=y_{k}\right) \\
& =\sum_{i=1} x_{i} \sum_{k=1} P\left(X=x_{i}, Y=y_{k}\right)=\sum_{i=1} x_{i} P\left(X=x_{i}\right)=E(X)
\end{aligned}
$$

hiszen a második sorban éppen $X$ peremeloszlását kapjuk. 
FIGYELEM! Vajon a második sorban miért cserélhető fel a két szumma?

21.11 Példa. Néha könnyebb $E(X)$ előállítása a fenti tételből, mint közvetlenül. Egy call center-be egy nap alatt érkező hívások száma Poisson-eloszlású adott $\lambda>0$ paraméterrel. Minden hívás egymástól függetlenül adott $p>0$ valószínúséggel téves. Adjuk meg egy adott napon a téves hívások számának várható értékét.

Jelentse $X$ a téves hívások számát, és $Y$ az összes beérkezô hívás számát. Világos, hogy adott $n \in \mathbb{N}$ esetén az $Y=n$ feltétel mellett éppen a Bernoulli-kísérlettel állunk szemben, ezért

$$
P(X=k \mid Y=n)=\left(\begin{array}{l}
n \\
k
\end{array}\right) p^{k}(1-p)^{n-k} \quad \text { ha } \quad n \geq k
$$

illetve $P(X=k \mid Y=n)=0$, ha $n<k$. Tehát a feltételes várható érték

$$
m_{n}=E(X \mid Y=n)=n p, \quad n=1,2, \ldots
$$

Innen a Teljes várható érték tétel alapján

$$
E(X)=E(E(X \mid Y))=\sum_{n=1}^{\infty} n p \frac{\lambda^{n}}{n !} e^{-\lambda}=\lambda p
$$

FIGYELEM! Állítsuk elő a várható értéket közvetlenül $X$ eloszlása alapján is!

\section{Otthoni tanuláshoz}

1. A Feladatgyưjitemény-2 V/4 és VI/5 szakaszainak feldolgozása.

2. Házi feladatok: a V/4 szakasz 471, 473, 482, 485, 489, 504, 509, valamint a VI/5 szakasz 608, 609 és 6.10 feladatai.

3. Tankönyv-2 6.14 és 8.3 szakaszai. 



\subsection{Diszkrét változók összegének eloszlása}

Tegyük fel, hogy $X$ és $Y$ független Poisson-eloszlású változók, rendre $\lambda>0$, illetve $\mu>$ 0 paraméterekkel. Határozzuk meg $X+Y$ eloszlását. Ekkor tetszőleges $k$ nemnegatív egész számra a függetlenség miatt

$$
\begin{aligned}
P(X+Y=k) & =\sum_{i=0}^{k} P(X=i, Y=k-i)=\sum_{i=0}^{k} P(X=i) \cdot P(Y=k-i) \\
& =\sum_{i=0}^{k} \frac{\lambda^{i}}{i !} e^{-\lambda} \cdot \frac{\mu^{k-i}}{(k-i) !} e^{-\mu}=\frac{e^{-(\lambda+\mu)}}{k !} \sum_{i=0}^{k}\left(\begin{array}{l}
k \\
i
\end{array}\right) \lambda^{i} \mu^{k-i} \\
& =\frac{(\lambda+\mu)^{k}}{k !} e^{-(\lambda+\mu)}
\end{aligned}
$$

Ez az eredményünk azt mutatja, hogy a két független változó összege is Poissoneloszlású $\lambda+\mu$ paraméterrel.

Ezt az állításunkat indukcióval tetszőleges véges számú változóra is kiterjeszthetjük.

22.1 Tétel. Tegyük fel, hogy $X_{1}, \ldots, X_{n}$ független Poisson-eloszlású valószínúségi változók rendre $\lambda_{1}, \ldots, \lambda_{n}$ pozitív paraméterekkel. Akkor az.

$$
Y_{n}=X_{1}+\ldots+X_{n}
$$

változó is Poisson-eloszlású, amelynek paramétere $\lambda_{1}+\ldots+\lambda_{n}$.

\subsection{Folytonos változók összegének eloszlása}

Legyenek most $X$ és $Y$ folytonos eloszlású független változók, amelyek súrúségfüggvényei $f$ illetve $g$. Jelölje $F$ illetve $G$ az eloszlásfüggvényeket. Jelentse $H$ az $X+Y$ eloszlásfüggvényét. Ennek előállításához válasszunk egy tetszőleges $x \in \mathbb{R}$ számot. Ábra készítésével láthatjuk, hogy

$$
\begin{aligned}
H(x) & =\iint_{t+s<x} f(s) g(t) d s d s=\int_{-\infty}^{\infty} \int_{-\infty}^{x-s} f(s) g(t) d t d s \\
& =\int_{-\infty}^{\infty} f(s)\left(\int_{-\infty}^{x-s} g(t) d t\right) d s=\int_{-\infty}^{\infty} f(s) G(x-s) d s .
\end{aligned}
$$

Innen az integrál deriválásával az $X+Y$ változó $h$ sûrúségfüggvémyére az adódik, hogy

$$
h(x)=\int_{-\infty}^{\infty} f(s) g(x-s) d s
$$

és ezt az $f$ és $g$ sűrúségfüggvények konvolúciós integráljának nevezzük. 
FIGYELEM! Az integrál deriválása a fenti levezetésben nem egyszerú. Vizsgáljuk meg ezt a szabályt néhány egyszerú, könnyen kiintegrálható esetben!

22.2 Példa. Tekintsünk most azt a példát, ahol $X$ és $Y$ független, egyenletes eloszlású változók a $[0,1]$ intervallumon. Ekkor $(X, Y)$ egyenletes eloszlású a sík egységnégyzetén. Ábra készítésével mutassuk meg, hogy ha $h$ jelenti az $X+Y$ változó sûrûségfüggvényét, akkor

$$
h(x)= \begin{cases}x & \text { ha } 0<x<1 \\ 2-x & \text { ha } 1<x<2 \\ 0 & \text { különben. }\end{cases}
$$

22.3 Példa. Legyenek most $X$ és $Y$ független, azonos $\lambda$-paraméterű exponenciális eloszlású változók, és tekintsük az $X+Y$ változó $h$ sürúségfüggvényét. Ha $f$ jelenti az exponenciális eloszlás sûrűségfüggvényét, akkor az előbbiek szerint a konvolúciós integrál

$$
h(x)=\int_{-\infty}^{\infty} f(s) f(x-s) d s
$$

alakú. Az exponenciális eloszlás sűrúségfüggvénye zérus a negatív félegyenesen, ezért ez az integrandus akkor csak akkor nem nulla, ha $s>0$ és $x-s>0$, azaz $0<s<x$. Tehát

$$
h(x)=\int_{0}^{x} \lambda^{2} e^{-\lambda s} e^{-\lambda(x-s)} d s=\lambda^{2} \int_{0}^{x} e^{-\lambda x} d s=\lambda^{2} x e^{-\lambda x}
$$

bármely $x>0$ esetén, hiszen az integrandus nem függ az $s$ változótól.

Teljes indukcióval igazolhatjuk a fenti eredményünk alábbi kiterjesztését.

22.4 Tétel. Tegyük fel, hogy $X_{1}, \ldots, X_{n}$ független exponenciális eloszlású valószínúségi változók ugyanazon $\lambda>0$ paraméterrel. Akkor az.

$$
Y_{n}=X_{1}+\ldots+X_{n}
$$

változó h sưrúségfüggvénye

$$
h(x)=\frac{\lambda^{n}}{(n-1) !} x^{n-1} e^{-\lambda x}
$$

hax $>0$, és $h(x)=0$, hax $\leq 0$. 


\subsection{A Poisson-folyamat}

Ebben a szakaszban az exponenciális eloszlás és a Poisson-eloszlás egy mélyebb összefüggésére világítunk rá.

Tekintsük a $T_{1}, T_{2}, \ldots$ valószínúségi változókat, amelyek egymás utáni várakozási időket jelentenek egymás utáni "bekövetkezések" között.

Gondoljunk például egymás utáni gépjármúvek közötti időtartamra egy autóúton, egy biztosítóhoz egymás után beérkező káresemények közötti időre, ügyfélablaknál egymást követő várakozási időkre, call-center-be beérkező hívások közötti időkre, stb.

Tegyük fel, hogy a $T_{1}, T_{2}, \ldots$ változók függetlenek és azonos $\lambda>0$ paraméterú exponenciális eloszlásúak. A várható értékre tekintettel minél kisebb a $\lambda$, annál hosszabbak a várható várakozási idők. Megjegyezzük, hogy az exponenciális eloszlás memórianélküli tulajdonságából adódik, hogy az eltelt várakozási időtôl független a további várakozás időtartama.

Jelölje a továbbiakban $S_{0}=0$ és

$$
S_{n}=T_{1}+\ldots+T_{n}
$$

amely a teljes várakozási időt jelenti az $n$-ik bekövetkezésig. Adott $t>0$ esetén az

$$
\left\{S_{n} \leq t\right\}
$$

esemény azt jelenti, hogy az $n$-ik bekövetkezés a $t$ időpont előtt történt. Ez azt jelenti, hogy a $[0, t]$ időintervallumban a bekövetkezések száma legalább $n$.

Jelentse tehát $N(t)$ a bekövetkezések számát a $[0, t]$ időintervallumban, ekkor az

$$
\{N(t) \geq n\}=\left\{S_{n} \leq t\right\}
$$

események megegyeznek. Minden $t>0$ esetén $N(t)$ egy valószínúségi változó, ezt a hozzárendelést Poisson-folyamatnak nevezzük.

Kérdés, hogy adott $t>0$ mellett hogyan határozhatjuk meg az $N(t)$ változó eloszlását? Az az esemény, hogy a $[0, t]$ intervallumban pontosan $n$ bekövetkezés történik

$$
\{N(t)=n\}=\left\{S_{n} \leq t\right\} \cap \overline{\left\{S_{n+1} \leq t\right\}}=\left\{S_{n} \leq t<S_{n+1}\right\} .
$$

Mivel $\left\{S_{n+1} \leq t\right\} \subset\left\{S_{n} \leq t\right\}$, innen a valószínúségre azt kapjuk, hogy

$$
P(N(t)=n)=P\left(S_{n} \leq t\right)-P\left(S_{n+1} \leq t\right) .
$$

Jelölje most $f_{n}$ az $S_{n}$ változó, illetve $f_{n+1}$ az $S_{n+1}$ változó sűrúségfüggvényét. Mivel $T_{1}, T_{2}, \ldots$ független, azonos $\lambda$-paraméterú exponenciális eloszlású változók, azért a megelőző szakasz Tétele alapján

$$
f_{n}(x)=\frac{\lambda^{n}}{(n-1) !} x^{n-1} e^{-\lambda x} \quad \text { illetve } \quad f_{n+1}(x)=\frac{\lambda^{n+1}}{n !} x^{n} e^{-\lambda x}
$$


minden $x>0$ esetén. Tehát

$$
P(N(t)=n)=P\left(S_{n} \leq t\right)-P\left(S_{n+1} \leq t\right)=\int_{0}^{t} f_{n}(x) d x-\int_{0}^{t} f_{n+1}(x) d x .
$$

Számítsuk ki a jobb oldalon álló elsô integrált parciális integrálással.

$$
\begin{aligned}
\int_{0}^{t} f_{n}(x) d x & =\frac{\lambda^{n}}{(n-1) !} \int_{0}^{t} x^{n-1} e^{-\lambda x} d x \\
& =\frac{\lambda^{n}}{(n-1) !}\left[\frac{x^{n}}{n} e^{-\lambda x}\right]_{0}^{t}+\frac{\lambda^{n}}{(n-1) !} \int_{0}^{t} \frac{x^{n}}{n} \lambda e^{-\lambda x} d x \\
& =\frac{(\lambda t)^{n}}{n !} e^{-\lambda t}+\frac{\lambda^{n+1}}{n !} \int_{0}^{t} x^{n} e^{-\lambda x} d x
\end{aligned}
$$

Vegyük észre, hogy a legutolsó integrálban éppen $f_{n+1}$ szerepel! Innen

$$
P(N(t)=n)=\frac{(\lambda t)^{n}}{n !} e^{-\lambda t}
$$

22.5 Tétel. A Poisson-folyamatban a $[0, t]$ idöintervallumban történó bekövetkezések száma $\lambda$ t-paraméterü Poisson-eloszlású valószínúségi változó.

\subsection{Normális eloszlások összege}

Legyenek $Z_{1}$ és $Z_{2}$ független, standard normális eloszlású valószínúségi változók, és határozzuk meg az

$$
Y=Z_{1}+Z_{2}
$$

változó eloszlását. A konvolúciós integrál ebben az esetben

$$
h(x)=\int_{-\infty}^{\infty} \varphi(s) \varphi(x-s) d s
$$

ahol $h$ az $Y$ sûrüségfüggvénye. Ekkor

$$
\begin{aligned}
h(x) & =\frac{1}{2 \pi} \int_{-\infty}^{\infty} e^{-s^{2} / 2} e^{-(x-s)^{2} / 2} d s=\frac{1}{2 \pi} e^{-\frac{x^{2}}{2}} \int_{-\infty}^{\infty} e^{x s-s^{2}} d s \\
& =\frac{1}{2 \pi} e^{-\frac{x^{2}}{2}} \int_{-\infty}^{\infty} e^{-(s-x / 2)^{2}} e^{x^{2} / 4} d s=\frac{1}{2 \pi} e^{-\frac{x^{2}}{4}} \int_{-\infty}^{\infty} e^{-(s-x / 2)^{2}} d s
\end{aligned}
$$

A legutolsó integrál éppen a Gauss-integrál, amelynek értéke $\sqrt{\pi}$, tehát

$$
h(x)=\frac{1}{2 \sqrt{\pi}} e^{-\frac{x^{2}}{4}} \quad-\infty<x<\infty
$$

Ez éppen annak a normális eloszlásnak a sûrúségfüggvénye, amelynek paraméterei $m=$ 0 és $\sigma=\sqrt{2}$. 
Teljesen hasonló gondolatmenettel a következó eredményt fogalmazhatjuk meg.

22.6 Tétel. Legyenek $Z_{1}, \ldots, Z_{n}$ független, standard normális eloszlású valószínüségi változók. Akkor az $Y=Z_{1}+\ldots+Z_{n}$ változó is normális eloszlású, amelynek paraméterei $m=0$ és $\sigma=\sqrt{n}$.

\subsection{Centrális határeloszlás-tétel}

Képzeljük el, hogy valamilyen (ismeretlen) $m$ mennyiség értékének meghatározására $n$ számú független kísérletet végzünk. Az ismeretlen mennyiség közelítéséhez a kísérletek kimeneteleinek számtani átlagát használjuk.

Jelölje a kísérletek kimeneteleit rendre $X_{1}, \ldots, X_{n}$ és tegyük fel, hogy ezek független, azonos eloszlású változók, amelyekre

$$
E\left(X_{k}\right)=m, \quad D\left(X_{k}\right)=\sigma, \quad k=1,2, \ldots, n
$$

Vezessük be a következő jelölést a változók standardizált átlagára:

$$
Y_{n}=\frac{\frac{1}{n}\left(X_{1}+\ldots+X_{n}\right)-m}{\sigma / \sqrt{n}}
$$

Tételeink szerint ennek az $Y_{n}$ változónak a várható értéke 0 és a szórása 1.

Alekszandr Ljapunov orosz matematikus és a korabeli (XX.szd eleje) matematika csodálatos felismerése volt, hogy a fenti $Y_{n}$ változó eloszlása tart a standard normális eloszláshoz.

22.7 Tétel. (Centrális határeloszlás-tétel) A fenti feltételek mellett jelölje $F_{n}$ az $Y_{n}$ eloszlásfüggvényét. Ekkor minden $x \in \mathbb{R}$ esetén

$$
\lim _{n \rightarrow \infty} F_{n}(x)=\Phi(x) .
$$

22.8 Példa. Egy kisforgalmú üzletbe egy adott napon 100 látogató érkezik. Mindegyik látogató (egymástól függetlenül) $p=0.2$ valószínúséggel vásárol valamit. Mi a valószínúsége, hogy az adott napon az üzletben vásárlók száma 15 és 25 között lesz? 
Jelölje $X$ a vásárlók számát. Ekkor $X$ binomiális eloszlású $n=100$ és $p=0.2$ paraméterekkel. Ha a $k$-ik vásárlóra bevezetjük az

$$
X_{k}= \begin{cases}0 & \text { ha nem vásárol } \\ 1 & \text { ha vásárol }\end{cases}
$$

jelölést, akkor $X=X_{1}+\ldots+X_{100}$. Könnyen látható, hogy minden $k$ esetén $E\left(X_{k}\right)=0.2$ és $\operatorname{Var}\left(X_{k}\right)=0.16$. Ez azt jelenti, hogy $E(X)=20$ és $\operatorname{Var}(X)=16$. Tehát

$$
P(15<X<25)=P\left(-\frac{5}{4}<\frac{X-20}{4}<\frac{5}{4}\right)
$$

A centrális határeloszlás-tétel alapján

$$
\begin{aligned}
P\left(-\frac{5}{4}<\frac{X-20}{4}<\frac{5}{4}\right) & \approx \Phi(1.25)-\Phi(-1.25) \\
& =2 \Phi(1.25)-1=0.7888
\end{aligned}
$$

adódik a standard normális eloszlás táblázata alapján, a Feladatgyújtemény-2 339-ik oldalán.

\section{Otthoni tanuláshoz}

1. A Feladatgyújtemény-2 V/3 és VI/5 szakaszainak feldolgozása.

2. Házi feladatok: a V/3 szakasz 445, 446, 447, 452, 453, 457, 468, valamint a VI/5 szakasz 608, 609 és 6.10 feladatai.

3. Tankönyv-2 6.10, 6.11 és 8.3 szakaszai. 



\subsection{Csebisev-egyenlötlenség}

Az eddigiekben számos esetben kellett meghatároznunk

$$
P(a<X<b)
$$

alakú valószínúségeket. Ez könnyen megtehető, ha ismert az $X$ valószínúségi változó eloszlása. Nevezetesen diszkrét változó esetében

$$
P(a<X<b)=\sum_{a<x_{k}<b} P\left(X=x_{k}\right)
$$

míg egy $f$ sûrüségfüggvénnyel rendelkező változóra

$$
P(a<X<b)=\int_{a}^{b} f(x) d x
$$

Vannak esetek, amikor így nem járhatunk el, például:

1. az $X$ változó eloszlása nem ismert,

2. az $X$ eloszlása ismert, de túl bonyolult a fenti valószínúség meghatározása.

Ilyen esetekben is megelégedhetünk azonban egy, a feladat szempontjából megfelelő becsléssel a fenti valószínűségre. Erre a kérdésre ad választ a Csebisev-egyenlőtlenség. Tekintsünk egy olyan $X$ valószínúségi változót, amelynek van várható értéke és szórása.

23.1 Tétel. (Csebisev-egyenlőtlenség) Legyen az $X$ valószínüségi változó várható értéke $E(X)=m$ és szórása $D(X)=\sigma$. Ekkor

$$
P(|X-m|<k \cdot \sigma) \geq 1-\frac{1}{k^{2}}
$$

bármely $k>0$ szám esetén.

Bizonyítás. A bizonyítást folytonos esetre mutatjuk meg, diszkrét esetben teljesen hasonlóan végezhető el. Legyen tehát $f$ az $X$ sûrúségfüggvénye, ekkor

$$
\sigma^{2}=\int_{-\infty}^{\infty}(x-m)^{2} f(x) d x
$$

Ha most $k>0$ adott, akkor a jobb oldalon álló integrál értéke nem nőhet, ha kihagyjuk az $[m-k \sigma, m+k \sigma]$ intervallumot az integrálási útból. Nevezetesen

$$
\sigma^{2} \geq \int_{-\infty}^{m-k \sigma}(x-m)^{2} f(x) d x+\int_{m+k \sigma}^{\infty}(x-m)^{2} f(x) d x
$$


hiszen az integrandus nemnegatív. Másrészt a $(-\infty, m-k \sigma]$ intervallum bármely $x$ pontjában $(x-m)^{2} \geq k^{2} \sigma^{2}$, ezért

$$
\int_{-\infty}^{m-k \sigma}(x-m)^{2} f(x) d x \geq \int_{-\infty}^{m-k \sigma} k^{2} \sigma^{2} f(x) d x \geq k^{2} \sigma^{2} P(X \leq m-k \sigma) .
$$

Teljesen hasonló módon látható, hogy az $[m+k \sigma, \infty)$ intervallum bármely $x$ pontjában $(x-m)^{2} \geq k^{2} \sigma^{2}$, és ezért

$$
\int_{m+k \sigma}^{\infty}(x-m)^{2} f(x) d x \geq \int_{m+k \sigma}^{\infty} k^{2} \sigma^{2} f(x) d x \geq k^{2} \sigma^{2} P(X \geq m+k \sigma) .
$$

Ha ezt a két utóbbi egyenlőtlenséget összevetjük a 23.1 alatti egyenlőtlenséggel, akkor az adódik, hogy

$$
\sigma^{2} \geq k^{2} \sigma^{2} P(X \leq m-k \sigma)+k^{2} \sigma^{2} P(X \geq m+k \sigma) .
$$

Mindkét oldalt elosztva a $k^{2} \sigma^{2}$ pozitív kifejezéssel

$$
\frac{1}{k^{2}} \geq P(X \leq m-k \sigma)+P(X \geq m+k \sigma)=P(|X-m| \geq k \sigma) .
$$

Innen az ellentett eseményre térve adódik a tételünk állítása.

Megjegyezzük, hogy a tételünk irreleváns eredményt ad, ha $k \leq 1$, ezért az egyenlőtlenséget csak a $k>1$ esetben fogjuk használni.

23.2 Példa. Például, ha egy $X$ változó eloszlása nem ismert, de azt tudjuk, hogy a várható értéke $E(X)=8$ és szórása $D(X)=2$, akkor

$$
P(2<X<14) \geq 1-\frac{1}{9} \approx 0.8889
$$

hiszen ekkor $k=3$.

\subsection{Csebisev-egyenlőtlenség ekvivalens alakban}

Néha kényelmesebb lehet a Csebisev-egyenlőtlenséget a következő alakban használni:

$$
P(|X-E(X)|<\varepsilon) \geq 1-\frac{\operatorname{Var}(X)}{\varepsilon^{2}}
$$

ahol $\varepsilon>0$. Valóban, ez az alak ekvivalens a tételünkkel, hiszen ha $k \cdot D(X)=\varepsilon>0$, akkor

$$
\frac{1}{k^{2}}=\frac{\operatorname{Var}(X)}{\varepsilon^{2}}
$$


Fogalmazzuk meg ezt az ekvivalens tételünket a következő alakban.

23.3 Tétel. Tegyük fel, hogy az $X$ valószínüségi változó várható értéke $E(X)=m$, és szórása $D(X)=\sigma$. Akkor bármely adott $\varepsilon>0$ esetén

$$
P(|X-m|<\varepsilon) \geq 1-\frac{\sigma^{2}}{\varepsilon^{2}}
$$

23.4 Példa. Képzeljük el, hogy egy forgalmas telefonközpontba egy óra alatt 2000 hívás érkezik. Mindegyik hívás (egymástól függetlenül) 0.002 valószínűséggel téves. Mi a valószínúsége, hogy legfeljebb 8 téves hívás érkezik?

Jelölje $X$ a téves hívások számát. Világos, hogy $X$ binomiális eloszlású, amelynek paraméterei $n=2000$ és $p=0.002$. A kérdéses valószínúség tehát:

$$
P(X \leq 8)=\sum_{k=0}^{8}\left(\begin{array}{c}
2000 \\
k
\end{array}\right) 0.002^{k} \cdot 0.998^{2000-k}
$$

aminek kiszámítása elég reménytelen feladat (bár az eloszlás ismert).

Adhatunk azonban becslést a Csebisev-egyenlőtlenséggel. Itt $m=4$ és $\sigma^{2}=4$. $0.998 \approx 4$, ezért

$$
P(X \leq 8)=P(|X-4|<5) \geq 1-\frac{4}{25}=0.84
$$

\subsection{Poisson-approximáció}

23.5 Példa. Egy 2000 ágyas központi kórházban annak valószínúsége, hogy egy adott napon egy betegnek intenzív kezelésre van szüksége (a többiektôl függetlenül) 0.002 . Az igazgató egy új intenzív osztályt kíván létrehozni úgy, hogy annak valószínúsége, hogy egy olyan beteg, akinek intenzív ápolásra van szüksége, nem kap ágyat az intenzív osztályon, kisebb legyen, mint 0.01 . Hány ágyas legyen a minimális költségú intenzív osztály?

Jelentse $N$ az ágyak számát és $X$ azon betegek számát, akiknek intenzív kezelés szükséges az adott napon, akkor (mivel $X$ nyilvánvalóan binomiális eloszlású $m=4$ várható értékkel, és $\sigma^{2}=4 \cdot 0.998 \approx 4$ varianciával),

$$
P(X \leq N)=\sum_{k=0}^{N}\left(\begin{array}{c}
2000 \\
k
\end{array}\right) 0.002^{k} 0.998^{2000-k} \geq 0.99
$$

és ez az egyenlőtlenség megoldandó az egyenlőtlenség a legkisebb $N$-re (amely a legkisebb költséget jelenti). 
Ez az az eset, amikor ugyan $X$ eloszlása ismert, de kezelhetetlenül bonyolult ahhoz, hogy eredményre jussunk. Ehelyett használhatjuk a Csebisev-egyenlőtlenséget:

$$
P(|X-4|<\varepsilon) \geq 1-\frac{4}{\varepsilon^{2}}=0.99
$$

ahonnan $\varepsilon=20$ és így $N=23$ adódik az új intenzív osztály ágyainak számára.

Általában a Csebisev-egyenlőtlenségtől (hiszen minden eloszlásra érvényes) nem várhatunk pontos becslést. Sokkal pontosabb eredményt kaphatunk, ha a Poissonapproximációt használjuk. Az approximációt leíró tételt lásd a 18.5 szakaszban. Nevezetesen

$$
\sum_{k=0}^{N}\left(\begin{array}{c}
2000 \\
k
\end{array}\right) 0.002^{k} 0.998^{2000-k} \approx \sum_{k=0}^{N} \frac{4^{k}}{k !} e^{-4}
$$

hiszen " $n=2000$ elég nagy és $p=0.002$ elég kicsi", továbbá $n p=4$. A Poissoneloszlás táblázatát vizsgálva (lásd Feladatgyújtemény-2, 332-ik oldal) azt láthatjuk, hogy a jobb oldali szumma $N=9$-nél lépi át a 0.99 értéket. Ezért ezen approximáció alapján a feladatra az $N=9$ megoldás adódik. (Azt nem vizsgáljuk, hogy ez mennyire pontos közelítés.)

\subsection{Nagy számok törvénye}

Képzeljük el, hogy egy kísérletet elvégzünk egymás után $n$ esetben, egymástól függetlenül, és minden esetben megfigyeljük, hogy egy bizonyos $A$ esemény bekövetkezik-e, vagy sem (Bernoulli-kísérlet).

Tegyük fel, hogy az $A$ esemény valószínúsége $P(A)=p$ (ahol $0 \leq p \leq 1)$ és jelölje $X$ azon kísérletek számát, amelyekben $A$ bekövetkezik. Világos, hogy ekkor $X / n$ az $A$ esemény relatív gyakoriságát jelenti.

Azt szeretnénk megvizsgálni, hogy a relatív gyakoriság közelít-e a valódi valószínúséghez, ha növeljük a kísérletek számát, azaz $n \rightarrow \infty$ ?

Ez a kérdés elvi jelentôségû, hiszen a pozitív válasz azt mutatja, hogy az axiómáinkból egy tapasztalati tényt vezethetünk le. Ez azt jelenti, hogy az eddig felépített axiomatikus elméletünk a valóságot tükrözi, tehát helyesen választottuk meg az axiómáinkat.

Világos, hogy $X$ binomiális eloszlású $n$ és $p$ paraméterekkel. Válasszunk egy $\varepsilon>0$ számot és használjuk fel a Csebisev-egyenlőtlenséget.

$$
P\left(\left|\frac{X}{n}-p\right| \geq \varepsilon\right)=P(|X-n p| \geq n \varepsilon)
$$

Mivel $E(X)=n p$ és $\operatorname{Var}(X)=n p(1-p)$, ez a Csebisev-egyenlőtlenség alapján úgy is írható, hogy

$$
P(|X-n p| \geq n \varepsilon) \leq \frac{n p(1-p)}{n^{2} \varepsilon^{2}}
$$


Mivel $p(1-p) \leq 1 / 4$ bármely $p$ valós számra, innen

$$
P\left(\left|\frac{X}{n}-p\right| \geq \varepsilon\right) \leq \frac{1}{4 n \varepsilon^{2}} \rightarrow 0
$$

ha $n \rightarrow \infty$. Ezt az eredményünket az alábbi tételben fogalmazhatjuk meg.

\subsection{Tétel. (Nagy számok Bernoulli-féle törvénye)}

$$
\lim _{n \rightarrow \infty} P\left(\left|\frac{X}{n}-p\right|<\varepsilon\right)=1
$$

bármely $\varepsilon>0$ mellett.

23.7 Példa. Egy közvéleménykutató cég választási előrejelzést készít egy párt számára. Választók megkérdezésével kívánnak becslést adni a párt százalékos támogatottságára. Hány választót kell megkérdezniük, hogy a felmérésből adódó arány a valódi aránytól $90 \%$ valószínúséggel legfeljebb 1\%-kal térjen el?

Jelölje $0<p<1$ az ismeretlen valódi arányt (a párt valóságos támogatottsága), erre kívánunk becslést kapni. Tegyük fel, hogy a minta (egyelőre ismeretlen) nagysága $n$ és jelentse ezek közül $X$ az adott párt támogatóinak számát.

Világos, hogy kísérletünk egy Bernoulli-kísérlet, ezért $X$ binomiális eloszlású, így $E(X)=n p$ és $\operatorname{Var}(X)=n p(1-p)$. Tehát a nagy számok törvénye szerint

$$
P\left(\left|\frac{X}{n}-p\right| \leq 0.01\right) \geq 1-\frac{1}{4 n \cdot 10^{-4}}
$$

A felmérésból adódó $X / n$ arányra ezért a feltételünk miatt

$$
1-\frac{1}{4 n \cdot 10^{-4}}=0.90
$$

teljesül, azaz $n=25000$.

Tehát a cégnek a kívánt pontosság eléréséhez ekkora mintát kell választania a felméréshez. Természetesen a gyakorlatban bonyolultabb statisztikai módszerek alkalmazásával ennél kisebb minta is elegendő lehet. Ugyanakkor nehéz garantálni, hogy a megkérdezett választók halmaza homogén és reprezentatív legyen, abban az értelemben, hogy a mintából adódó arány tükrözze a teljes választói arányt.

\section{Otthoni tanuláshoz}

1. A Feladatgyújtemény-2 IV/3 szakaszának feldolgozása.

2. Házi feladatok: a IV/3 szakasz 396, 397, 398, 402, 403, 404, 408 és 409 feladatai.

3. Tankönyv-2 5.1, 5.2 és 5.3 szakaszai. 




\subsection{Kétdimenziós normális eloszlás}

24.1 Definíció. Legyen $r$ olyan adott valós szám, amelyre $|r|<1$. Ha az $X$ és $Y$ változók együttes sûrüségfüggvénye

$$
h(x, y)=\frac{1}{2 \pi \sqrt{1-r^{2}}} e^{-\frac{x^{2}-2 r x y+y^{2}}{2\left(1-r^{2}\right)}}
$$

akkor azt mondjuk, hogy $X$ és $Y$ normális együttes eloszlású $r$ paraméterrel.

24.2 Tétel. Ha X és $Y$ együttes sürüségfüggvénye a (24.1) alatti függvény, akkor X és $Y$ peremeloszlásai egyaránt standard normális eloszlások.

Bizonyítás. Mivel a sűrűségfüggvény a két változóban szimmetrikus, ezért elég az állítást az $X$ változó peremsûrűségfüggvényére igazolni.

Ha $f$ jelenti az $X$ sűrűségfüggvényét, akkor

$$
f(x)=\int_{-\infty}^{\infty} h(x, y) d y=\frac{1}{2 \pi \sqrt{1-r^{2}}} \int_{-\infty}^{\infty} e^{-\frac{x^{2}-2 r x y+y^{2}}{2\left(1-r^{2}\right)}} d y
$$

Teljes négyzetté alakítással az integrál mögötti exponenciális függvény úgy írható, hogy

$$
-\frac{x^{2}-2 r x y+y^{2}}{2\left(1-r^{2}\right)}=-\frac{x^{2}}{2}-\frac{(y-r x)^{2}}{2\left(1-r^{2}\right)} .
$$

Ha az integrálból kiemeljük az y-tól nem függő részt, akkor azt kapjuk, hogy

$$
f(x)=\frac{1}{2 \pi \sqrt{1-r^{2}}} e^{-\frac{x^{2}}{2}} \int_{-\infty}^{\infty} e^{-\frac{(y-r x)^{2}}{2\left(1-r^{2}\right)}} d y
$$

Vezessük be ebben az improprius integrálban a

$$
t=\frac{y-r x}{\sqrt{1-r^{2}}}
$$

helyettesítést, akkor az adódik, hogy

$$
f(x)=\frac{1}{2 \pi \sqrt{1-r^{2}}} e^{-\frac{x^{2}}{2}} \int_{-\infty}^{\infty} e^{-t^{2} / 2} \cdot \sqrt{1-r^{2}} d t
$$

A $\sqrt{1-r^{2}}$ kifejezéssel egyszerúsítve láthatjuk, hogy az utolsó integrál éppen a Gaussintegrál, amelynek értéke $\sqrt{2 \pi}$, tehát

$$
f(x)=\frac{1}{\sqrt{2 \pi}} e^{-\frac{x^{2}}{2}} \quad-\infty<x<\infty
$$

ami éppen a standard normális sûrúségfüggvény. 


\subsection{Korrelálatlan normális eloszlások}

24.3 Definíció. Az $X$ és $Y$ valószínúségi változókat korrelálatlannak nevezzük, ha $\operatorname{Corr}(X, Y)=0$.

Amint láttuk, a független változók korrelálatlanok, de példán láttuk, hogy ennek az állításnak a megfordítása általában nem érvényes. Normális eloszlású változók esetében azonban a két fogalom ekvivalens.

Tekintsük ebben a szakaszban újra a

$$
h(x, y)=\frac{1}{2 \pi \sqrt{1-r^{2}}} e^{-\frac{x^{2}-2 r x y+y^{2}}{2\left(1-r^{2}\right)}}
$$

kétdimenziós normális sûrúségfüggvényt, és határozzuk meg az $X$ és $Y$ változók $\operatorname{Corr}(X, Y)$ korrelációs együtthatóját. Az előző szakaszban láttuk, hogy $X$ és $Y$ peremeloszlásai standard normális eloszlások, ezért

$$
E(X)=E(Y)=0 \quad \text { és } \quad D(X)=D(Y)=1
$$

A szorzat várható értékét az

$$
E(X Y)=\int_{-\infty}^{\infty} x y h(x, y) d x d y=\frac{1}{2 \pi \sqrt{1-r^{2}}} \int_{-\infty}^{\infty} x y e^{-\frac{x^{2}-2 r x y+y^{2}}{2\left(1-r^{2}\right)}} d x d y
$$

integrál szolgáltatja. Ezt az integrált kétváltozós helyettesítéssel lehet kiszámolni, ez az eljárás azonban túlmegy a tankönyvünk keretein. A részletes számítást megtaláljuk a Tankönyv-2 198-ik oldalán. Eszerint $E(X Y)=r$, és innen azonnal következik, hogy

$$
\operatorname{Corr}(X, Y)=r \text {. }
$$

Mivel $r=0$ esetén a $h$ együttes sûrűségfüggvény láthatóan két standard normális sûrûségfüggvény szorzatára bomlik, azaz $X$ és $Y$ függetlenek, megfogalmazhatjuk a következő állítást.

24.4 Tétel. Ha az X és $Y$ változók együttes eloszlását a 24.1) alatti együttes sürüségfüggvény szolgáltatja, úgy X és $Y$ akkor és csak akkor függetlenek, ha korrelálatlanok.

\subsection{Normálisból származtatott eloszlások}

24.5 Példa. Állítsuk elő a standard normális eloszlású $Z$ változó négyzetének eloszlását. Jelölje $H$, illetve $h$ a $Z^{2}$ eloszlás, illetve sưrúségfüggvényét. 
Ekkor tetszőleges $x>0$ mellett

$$
H(x)=P\left(Z^{2}<x\right)=P(|Z|<\sqrt{x})=P(-\sqrt{x}<Z<\sqrt{x})=2 \Phi(\sqrt{x})-1
$$

továbbá $H(x)=0$, ha $x \leq 0$. Innen deriválással adódik, hogy

$$
h(x)=\frac{1}{2 \sqrt{x}} 2 \varphi(\sqrt{x})=\frac{1}{\sqrt{2 \pi}} x^{-\frac{1}{2}} e^{-\frac{x}{2}} \text { ha } x>0,
$$

és $h(x)=0$, ha $x \leq 0$. Ennek az eloszlásnak a várható értékére és szórására

$$
E\left(Z^{2}\right)=1, \quad \operatorname{Var}\left(Z^{2}\right)=2
$$

adódik.

24.6 Példa. Legyenek most $Z_{1}$ és $Z_{2}$ független, standard normális eloszlású valószínúségi változók, és tekintsük a

$$
\chi^{2}=Z_{1}^{2}+Z_{2}^{2}
$$

összeget. Jelentse $h$ a $Z_{1}^{2}$ és $Z_{2}^{2}$ változók sûrúségfüggvényét, továbbá $k$ a $\chi^{2}$ sûrúségfüggvényét. Ekkor az előző példa alapján a konvolúciós integrál a következő alakot ölti:

$$
k(x)=\int_{-\infty}^{\infty} h(s) h(x-s) d s .
$$

Az integrandus akkor és csak akkor nem nulla, ha $s>0$ és $x-s>0$, azaz ha $0<s<x$. Tehát a konvolúciós integrál úgy írható, hogy

$$
k(x)=\frac{1}{2 \pi} \int_{0}^{x} s^{-\frac{1}{2}} e^{-\frac{s}{2}}(x-s)^{-\frac{1}{2}} e^{-\frac{x-s}{2}} d s=\frac{1}{2 \pi} e^{-\frac{x}{2}} \int_{0}^{x}\left(s x-s^{2}\right)^{-\frac{1}{2}} d s
$$

Ez utóbbi integrál elég komplikált, kiszámítása az úgynevezett Euler-féle bétafüggvényhez vezet (lásd a Tankönyv-2 247-ik oldalát), és az értéke $\pi$. Ennek alapján

$$
k(x)=\frac{1}{2} e^{-\frac{x}{2}} \quad \text { ha } \quad x>0
$$

és $k(x)=0$, ha $x \leq 0$, ami éppen az 1/2-paraméterú exponenciális eloszlás. Ezért

$$
E\left(\chi^{2}\right)=2, \quad \text { és } \operatorname{Var}\left(\chi^{2}\right)=4
$$

adódik a várható értékre és a varianciára. 


\subsection{A $\chi^{2}$-eloszlás, a $t$-eloszlás és az $F$-eloszlás}

24.7 Definíció. Tekintsük a $Z_{1}, \ldots Z_{n}$ független, standard normális eloszlású valószínúségi változókat. Ekkor a

$$
\chi_{n}^{2}=Z_{1}^{2}+\ldots+Z_{n}^{2}
$$

változót $n$-szabadságfokú $\chi^{2}$-eloszlásúnak nevezzük.

Ennek a változónak a várható értéke és varianciája

$$
E\left(\chi_{n}^{2}\right)=n \quad \text { és } \operatorname{Var}\left(\chi_{n}^{2}\right)=2 n
$$

az előző szakasz példája alapján.

24.8 Definíció. Tekintsük a $Z_{1}, \ldots Z_{n}$ és $Z$ független, standard normális eloszlású valószínûségi változókat. Ekkor a

$$
t_{n}=\frac{Z \sqrt{n}}{\sqrt{Z_{1}^{2}+\ldots+Z_{n}^{2}}}
$$

valószínűségi változót $n$-szabadságfokú t-eloszlásnak nevezzük.

Ennek az eloszlásnak $n=1$ esetén nem létezik várható értéke, míg $n \geq 2$ mellett $E\left(t_{n}\right)=0$. Az is megmutatható, hogy $n<3$ esetén a variancia nem létezik, továbbá

$$
\operatorname{Var}\left(t_{n}\right)=\frac{n}{n-2}
$$

ha $n \geq 3$.

24.9 Definíció. Legyenek most $X_{1}, \ldots, X_{m}$ és $Y_{1}, \ldots, Y_{n}$ független, standard normális eloszlású valószínúségi változók. Ekkor az

$$
F_{m, n}=\frac{\frac{1}{m} \sum_{k=1}^{m} X_{k}^{2}}{\frac{1}{n} \sum_{k=1}^{n} Y_{k}^{2}}
$$

változót $(m, n)$-szabadságfokú F-eloszlásnak nevezzük.

\section{Otthoni tanuláshoz}

1. A Feladatgyújtemény-2 VI/5 és VI/6 szakaszainak feldolgozása.

2. Házi feladatok: a VI/6 szakasz feladatai. Egész féléves ismétlés és az internetes oldalon kijelölt minta vizsgafeladatok gyakorlása.

3. Tankönyv-2 6.15, 9.5, 9.6 és 9.7 szakaszai. 
III. rész

Harmadik félév:

Lineáris algebra 

25. VEKTORTEREK ÉS ALTEREK 



\subsection{Az $\mathbb{R}^{n}$ vektortér}

Legyen $n$ adott természetes szám. Az $\mathbb{R}^{n}$ halmazt az összes valós szám $n$-esek halmazaként értelmezzük, azaz:

$$
\mathbb{R}^{n}=\left\{x=\left[\begin{array}{c}
x_{1} \\
\vdots \\
x_{n}
\end{array}\right]: x_{1}, \ldots, x_{n} \in \mathbb{R}\right\}
$$

E halmaz elemeit vektoroknak, a komponenseit koordinátáknak nevezzük. A szokásos koordinátákra gondolva ez a halmaz $n=2$ esetén a síkot, $n=3$ esetén a háromdimenziós teret adja.

A továbbiakban a vektorokat általában kis latin betúkkel, a valós számokat, vagy más néven skalárokat, kis görög betúkkel jelöljük.

$\mathrm{Az} \mathbb{R}^{n}$ vektorai között az alábbi múveleteket értelmezzük:

Vektorok összege

$$
x=\left[\begin{array}{c}
x_{1} \\
\vdots \\
x_{n}
\end{array}\right] \text { és } y=\left[\begin{array}{c}
y_{1} \\
\vdots \\
y_{n}
\end{array}\right] \text { esetén } x+y=\left[\begin{array}{c}
x_{1}+y_{1} \\
\vdots \\
x_{n}+y_{n}
\end{array}\right] \in \mathbb{R}^{n}
$$

\section{Vektor szorzása skalárral}

$$
\alpha \in \mathbb{R} \text { és } x=\left[\begin{array}{c}
x_{1} \\
\vdots \\
x_{n}
\end{array}\right] \text { esetén } \alpha x=\left[\begin{array}{c}
\alpha x_{1} \\
\vdots \\
\alpha x_{n}
\end{array}\right] \in \mathbb{R}^{n}
$$

Ezekkel a múveletekkel ellátva az $\mathbb{R}^{n}$ halmazt vektortérnek nevezzük.

25.1 Definíció. Legyenek $a_{1}, \ldots, a_{k}$ vektorok a vektortérben, és $\alpha_{1}, \ldots, \alpha_{k}$ tetszóleges valós számok (skalárok). Az

$$
\alpha_{1} a_{1}+\ldots+\alpha_{k} a_{k}
$$

vektort az $a_{1}, \ldots, a_{k}$ vektorok egy lineáris kombinációjának nevezzük.

25.2 Példa. Legyenek például

$$
a_{1}=\left[\begin{array}{r}
2 \\
-1 \\
3
\end{array}\right] \text { és } a_{2}=\left[\begin{array}{l}
3 \\
0 \\
4
\end{array}\right] \text { továbbá } \alpha_{1}=3 \text { és } \alpha_{2}=-2
$$

akkor

$$
\alpha_{1} a_{1}+\alpha_{2} a_{2}=\left[\begin{array}{r}
0 \\
-3 \\
1
\end{array}\right]
$$




\subsection{Alterek}

25.3 Definíció. Az $\mathbb{R}^{n}$ vektortér egy $M$ részhalmazát altérnek nevezzük, ha

- bármely $x, y \in M$ esetén $x+y \in M$, és

- bármely $x \in M$ és $\alpha \in \mathbb{R}$ esetén $\alpha x \in M$.

A definícióból világos, hogy egy altér a 0 vektort mindig tartalmazza. A legszúkebb altér az egyelemú $\{0\}$ altér, a legbővebb az egész vektortér.

25.4 Tétel. Ha $M$ altér, akkor bármely $a_{1}, \ldots, a_{k} \in M$ vektorok és bármely $\alpha_{1}, \ldots, \alpha_{k} \in$ $\mathbb{R}$ skalárok esetén

$$
\alpha_{1} a_{1}+\ldots+\alpha_{k} a_{k} \in M
$$

Könnyen látható, hogy például az $\mathbb{R}^{3}$ vektortérben az origón átmenő egyenesek illetve síkok egyaránt alterek.

25.5 Példa. Tekintsük az $\mathbb{R}^{n}$ vektortér következő részhalmazát:

$$
M=\left\{x=\left[\begin{array}{c}
x_{1} \\
\vdots \\
x_{n}
\end{array}\right] \in \mathbb{R}^{n}: x_{1}+x_{2}=0\right\}
$$

Mutassuk meg, hogy $M$ altér.

Valóban, ha $x, y \in M$, akkor $x_{1}+x_{2}=0$ és $y_{1}+y_{2}=0$, ezért az $x+y$ vektor első két koordinátájára is $\left(x_{1}+y_{1}\right)+\left(x_{2}+y_{2}\right)=0$. Ez azt jelenti, hogy $x+y \in M$.

Teljesen hasonlóan, ha $x \in M$ és $\alpha \in \mathbb{R}$, akkor az $x_{1}+x_{2}=0$ egyenlőségből adódik, hogy $\alpha\left(x_{1}+x_{2}\right)=0$, tehát $\alpha x \in M$.

Könnyen elképzelhető, hogy $n=3$ estén a fenti $M$ altér egy olyan, az alapsíkra merôleges sík, amely tartalmazza a harmadik tengelyt, és az alapsíkot a $-45^{\circ}$-os egyenesben metszi. KÉSZÍTSÜNK ÁBRÁT!

Az is könnyen ellenőrizhető, hogy ha az $M$ halmaz definíciójában $x_{1}+x_{2}$ értékének bármilyen nullától különböző számot írtunk volna elő, akkor az $M$ nem lett volna altér. Ekkor az összeadás és a skalárral való szorzás is kivezetett volna az $M$ halmazból.

25.6 Tétel. Alterek metszete is altér.

Bizonyítás. Elég az állítást két altérre igazolni, a bizonyítás tetszőleges számú altérre hasonlóan megy. 
Legyenek $L$ és $M$ alterek. Ha $x, y \in L \cap M$, akkor $x+y \in L$ és $x+y \in M$, mert mindketten alterek. Tehát $x+y \in L \cap M$.

Teljesen hasonlóan, ha $x \in L \cap M$ és $\alpha \in \mathbb{R}$, akkor $\alpha x \in L$ és $\alpha x \in M$, mert mindketten alterek. Ezért $\alpha x \in L \cap M$.

\subsection{Generált altér}

A 25.6 Tétel alapján beszélhetünk adott vektorokat tartalmazó legszúkebb altérrôl. Ezt fogalmazza meg a következő definíció.

25.7 Definíció. Az $a_{1}, \ldots, a_{k}$ vektorokat tartalmazó legszúkebb alteret, jelölésben:

$$
\operatorname{lin}\left\{a_{1}, \ldots, a_{k}\right\}
$$

ezen vektorokat tartalmazó összes altér metszeteként értelmezzük, és az adott vektorok által generált altérnek nevezzük.

Mivel egy altér a vektorainak összes lineáris kombinációit tartalmazza, és ezek már önmagukban is alteret alkotnak, megfogalmazhatjuk az alábbi tételt.

25.8 Tétel. $A z a_{1}, \ldots, a_{k}$ vektorok által generált altér ezen vektorok összes

$$
\alpha_{1} a_{1}+\ldots+\alpha_{k} a_{k}
$$

lineáris kombinációinak halmaza, ahol $\alpha_{1}, \ldots, \alpha_{k} \in \mathbb{R}$.

25.9 Példa. Például, ha az $\mathbb{R}^{3}$ vektortérben tekintjük az

$$
a_{1}=\left[\begin{array}{l}
1 \\
0 \\
0
\end{array}\right] \text { és } a_{2}=\left[\begin{array}{l}
0 \\
1 \\
0
\end{array}\right]
$$

vektorokat, akkor

$$
\operatorname{lin}\left\{a_{1}, a_{2}\right\}=\left\{x=\left[\begin{array}{l}
x_{1} \\
x_{2} \\
x_{3}
\end{array}\right] \in \mathbb{R}^{3}: x_{3}=0\right\}
$$

azaz mindazon vektorok halmaza, amelyek harmadik koordinátája nulla. Gondoljuk meg, hogy ez a halmaz valóban altér! 


\subsection{Lineáris függetlenség}

25.10 Definíció. Az $\mathbb{R}^{n}$ vektortér $a_{1}, \ldots, a_{k}$ vektorait lineárisan függetlennek nevezzük, ha valamely $\alpha_{1}, \ldots, \alpha_{k}$ skalárokra

$$
\alpha_{1} a_{1}+\ldots+\alpha_{k} a_{k}=0 \Rightarrow \alpha_{1}=\ldots=\alpha_{k}=0 .
$$

Ellenkező esetben a vektorokat lineárisan összefüggóknek nevezzük.

A lineáris függetlenség az algebra egyik legfontosabb alapfogalma, azt fogalmazza meg, hogy a vektorok egy lineáris kombinációja CSAK úgy lehet 0 , ha minden együttható 0 .

FIGYELEM! A definíció nem azt mondja, hogy ha minden együttható 0, akkor a lineáris kombináció is 0 , ez ugyanis nyilvánvaló! Az implikáció fordított irányú!

Független vektorok közül egyik sem fejezhető ki a többi lineáris kombinációjaként. Ezt fogalmazza meg a következő tételünk.

25.11 Tétel. Az $a_{1}, \ldots, a_{k}$ vektorok akkor és csak akkor lineárisan összefüggók, ha valamelyik kifejezhetố a többi lineáris kombinációjaként.

Bizonyítás. Ha valamelyik vektor, például $a_{1}$ kifejezhető a többi vektor lineáris kombinációjaként, akkor

$$
a_{1}=\alpha_{2} a_{2}+\ldots+\alpha_{k} a_{k} .
$$

Ezt átrendezve azt kapjuk, hogy

$$
-a_{1}+\alpha_{2} a_{2}+\ldots+\alpha_{k} a_{k}=0 .
$$

Ez azt jelenti, hogy a lineáris kombináció úgy nulla, hogy az első együttható nem nulla. Tehát a vektorok nem függetlenek.

Fordítva, tegyük fel, hogy a vektorok összefüggők. Ekkor van olyan lineáris kombináció, amelyre

$$
\alpha_{1} a_{1}+\ldots+\alpha_{k} a_{k}=0,
$$

de nem minden együttható nulla, például éppen $\alpha_{1} \neq 0$. Akkor

$$
a_{1}=-\frac{\alpha_{2}}{\alpha_{1}} a_{2}-\ldots-\frac{\alpha_{k}}{\alpha_{1}} a_{k},
$$

azaz $a_{1}$ kifejezhető a többi vektor lineáris kombinációjaként.

25.12 Példa. Tekintsük a következô vektorokat az $\mathbb{R}^{3}$ térben

$$
a_{1}=\left[\begin{array}{r}
2 \\
-1 \\
3
\end{array}\right] \quad a_{2}=\left[\begin{array}{l}
3 \\
0 \\
4
\end{array}\right] \quad a_{3}=\left[\begin{array}{r}
1 \\
-2 \\
2
\end{array}\right]
$$

és döntsük el, hogy lineárisan függetlenek-e. 
Egyszerú számolással láthatjuk, hogy $a_{3}=2 a_{1}-a_{2}$, ezért a fenti vektorok összefüggôk.

Az alábbi egyszerú állítások könnyen ellenőrizhetők a definíció alapján.

25.13 Tétel. Tekintsük az $a_{1}, \ldots, a_{k}$ vektorokat az $\mathbb{R}^{n}$ vektortérben.

- Ha a vektorok lineárisan függetlenek, akkor bármely részhalmazuk is az.

- Ha a vektorok között szerepel a 0, akkor lineárisan összefüggók.

- Ha a vektorok között szerepel két azonos, akkor lineárisan összefüggók.

- Ha a vektorok összefüggók, akkor bármilyen vektorral bôvítve is összefüggók.

Bizonyítás. Csak útmutatót adunk a bizonyítás elvégzéséhez, a részletek kidolgozása házi feladat.

- Tekintsük a részhalmaz egy lineáris kombinációját, és szerepeltessük a hiányzó vektorokat nulla együtthatóval.

- Tekintsük a vektorok egy olyan lineáris kombinációját, amelyben a nulla vektor az 1, az összes többi vektor nulla együtthatóval szerepel.

- Tekintsük a vektorok egy olyan lineáris kombinációját, amelyben a két azonos vektor +1 illetve -1 együtthatóval, az összes többi vektor nulla együtthatóval szerepelnek.

- Tekintsük a vektorok egy olyan lineáris kombinációját, amely nulla, de nem minden együttható nulla, és szerepeltessük a kibővített vektorokat nulla együtthatóval.

25.14 Példa. Tegyük fel, hogy az $a, b$ és $c$ vektorok lineárisan függetlenek. Vajon igaz-e, hogy az $a+b, b+c, c+a$ vektorok is lineárisan függetlenek?

Irjuk fel az adott vektorok egy lineáris kombinációját, amelyről tegyük fel, hogy nulla:

$$
\alpha_{1}(a+b)+\alpha_{2}(b+c)+\alpha_{3}(c+a)=0 .
$$

Rendezve az egyenlőséget

$$
\left(\alpha_{1}+\alpha_{3}\right) a+\left(\alpha_{1}+\alpha_{2}\right) b+\left(\alpha_{2}+\alpha_{3}\right) c=0
$$

A függetlenség miatt innen az adódik, hogy

$$
\alpha_{1}+\alpha_{3}=0 \quad \alpha_{1}+\alpha_{2}=0 \quad \alpha_{2}+\alpha_{3}=0
$$

Ennek egyetlen megoldása $\alpha_{1}=\alpha_{2}=\alpha_{3}=0$, azaz az $a+b, b+c$ és $c+a$ vektorok is lineárisan függetlenek. 


\section{Otthoni tanuláshoz}

1. A Feladatgyưjtemény-1 II/1 és II/3 szakaszok kidolgozott példáinak feldolgozása.

2. Házi feladatok: a II/1 szakasz 1.1.3, 1.1.4, 1.2.2, 1.2.3, továbbá a II/3 szakasz 3.1.3, 3.1.4, 3.2.3, 3.2.4, 3.3.2 és 3.3.4 feladatai. feladatai.

3. Tankönyv-1 12.1, 12.2, 12.3, és 12.4 szakaszai. 


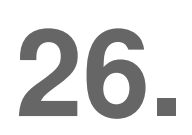

LINEÁRIS FÜGGETLENSÉG ÉS BÁZIS 



\subsection{Generátorrendszer}

26.1 Definíció. Az $\mathbb{R}^{n}$ vektortérben az $a_{1}, \ldots, a_{k}$ vektorrendszert generátorrendszernek nevezzük, ha

$$
\operatorname{lin}\left\{a_{1}, \ldots, a_{k}\right\}=\mathbb{R}^{n},
$$

azaz a tér minden vektora előáll az adott vektorok lineáris kombinációjaként.

26.2 Példa. Tekintsük a következő vektorokat az $\mathbb{R}^{3}$ térben

$$
a_{1}=\left[\begin{array}{l}
1 \\
0 \\
0
\end{array}\right] \quad a_{2}=\left[\begin{array}{l}
0 \\
1 \\
0
\end{array}\right] \quad a_{3}=\left[\begin{array}{r}
3 \\
-2 \\
0
\end{array}\right]
$$

és döntsük el, hogy generátorrendszert alkotnak-e.

Könnyú meggondolni, hogy nem alkotnak generátorrendszert, hiszen egyetlen olyan vektort sem tudunk kifejezni, amelyiknek a harmadik koordinátája nem nulla. Ezek a vektorok nem is függetlenek, hiszen $a_{3}=3 a_{1}-2 a_{2}$.

Ugyanakkor a következő vektorrendszer

$$
e_{1}=\left[\begin{array}{l}
1 \\
0 \\
0
\end{array}\right] \quad e_{2}=\left[\begin{array}{l}
0 \\
1 \\
0
\end{array}\right] \quad e_{3}=\left[\begin{array}{l}
0 \\
0 \\
1
\end{array}\right]
$$

generátorrendszert alkot, hiszen bármely $x$ vektor elóállítható az alábbi módon:

$$
x=x_{1} e_{1}+x_{2} e_{2}+x_{3} e_{3},
$$

ahol $x_{1}, x_{2}, x_{3}$ az $x$ vektor koordinátái. Egyszerúen ellenőrizhető, hogy ezek a vektorok egyébként lineárisan függetlenek is.

Teljesen hasonlóan értelmezhetjük az $\mathbb{R}^{n}$ valamely $M$ alterének generátorrendszerét is.

26.3 Definíció. Azt mondjuk, hogy az $a_{1}, \ldots, a_{k}$ vektorok az $M$ altér generátorrendszerét alkotják (vagy az $M$ alteret generálják), ha az $M$ bármely vektora elóállítható az $a_{1}, \ldots, a_{k}$ vektorok lineáris kombinációjaként. 


\subsection{Bázis}

26.4 Definíció. Az $\mathbb{R}^{n}$ vektortérben az $a_{1}, \ldots, a_{k}$ vektorrendszert bázisnak nevezzük, ha

- lineárisan független rendszer, és

- generátorrendszer.

26.5 Példa. Ahogy az előző példánkban láttuk, az $\mathbb{R}^{3}$ vektortérben az

$$
e_{1}=\left[\begin{array}{l}
1 \\
0 \\
0
\end{array}\right] \quad e_{2}=\left[\begin{array}{l}
0 \\
1 \\
0
\end{array}\right] \quad e_{3}=\left[\begin{array}{l}
0 \\
0 \\
1
\end{array}\right]
$$

vektorrendszer bázis, hiszen egyszerre lineárisan független és generátorrendszer. Teljesen hasonlóan látható, hogy az

$$
a_{1}=\left[\begin{array}{l}
1 \\
1 \\
1
\end{array}\right] \quad a_{2}=\left[\begin{array}{l}
0 \\
1 \\
1
\end{array}\right] \quad a_{3}=\left[\begin{array}{l}
0 \\
0 \\
1
\end{array}\right]
$$

vektorrendszert ugyancsak bázist alkot. (Ellenőrizzük!) Ugyanakkor a

$$
a_{1}=\left[\begin{array}{l}
2 \\
0 \\
0
\end{array}\right] \quad a_{2}=\left[\begin{array}{r}
0 \\
-1 \\
0
\end{array}\right]
$$

vektorrendszer nem bázis, hiszen nem alkot generátorrendszert (bár lineárisan független).

A definíciója alapján ellenőrizhetjük a bázis következő tulajdonságait.

- Egy bázis maximális elemszámú lineárisan független rendszer.

- Egy bázis minimális elemszámú generátorrendszer.

- Egy vektortérben minden bázis azonos elemszámú.

- Egy vektortérben bármely vektor egyértelmúen írható fel a bázisvektorok lineáris kombinációjaként. 
26.6 Definíció. $\quad \mathrm{Az} \mathbb{R}^{n}$ vektortérben az alábbi vektorrendszert standard bázisnak nevezzük:

$$
e_{1}=\left[\begin{array}{c}
1 \\
0 \\
\vdots \\
0
\end{array}\right] \quad e_{2}=\left[\begin{array}{c}
0 \\
1 \\
\vdots \\
0
\end{array}\right] \quad \ldots \quad e_{n}=\left[\begin{array}{c}
0 \\
0 \\
\vdots \\
1
\end{array}\right]
$$

ezekre a vektorokra a továbbiakban mindig az $e_{k}$ jelölést használjuk $(k=1, \ldots, n)$.

Ellenőrizzük, hogy ezek a vektorok valóban bázist alkotnak! Bizonyos értelemben a vektortérben ez a "legegyszerúbb" bázis, hiszen bármely $x$ vektor esetében

$$
x=x_{1} e_{1}+\ldots+x_{n} e_{n} .
$$

ahol $x_{1}, \ldots, x_{n}$ az $x$ vektor koordinátáit jelölik.

\subsection{Dimenzió}

A bázis tulajdonságai alapján bevezethetjük az alábbi definíciót.

26.7 Definíció. Egy vektortér vagy altér dimenzióján a benne található maximális lineárisan független rendszer (azaz bázis) elemszámát értjük.

26.8 Példa. A 26.6 Példa értelmében bármely $n$ természetes számra

$$
\operatorname{dim} \mathbb{R}^{n}=n
$$

hiszen az $e_{1}, \ldots, e_{n}$ független rendszer maximális, azaz tovább nem bővíthető.

26.9 Példa. Tekintsük most az

$$
a_{1}=\left[\begin{array}{r}
2 \\
2 \\
-3
\end{array}\right] \quad a_{2}=\left[\begin{array}{r}
1 \\
-1 \\
1
\end{array}\right] \quad a_{3}=\left[\begin{array}{r}
5 \\
3 \\
-5
\end{array}\right]
$$

vektorok által generált $M$ alteret, és határozzuk meg a dimenzióját!

Könnyen ellenőrizhető, hogy $a_{1}$ és $a_{2}$ lineárisan függetlenek, de $a_{1}, a_{2}, a_{3}$ már nem, hiszen

$$
2 a_{1}+a_{2}=a_{3} .
$$

Ezért a generált altér dimenziójára az adódik, hogy

$$
\operatorname{dim} M=\operatorname{dim} \operatorname{lin}\left\{a_{1}, a_{2}, a_{3}\right\}=2 .
$$

Az előző megállapításunk szerint persze az is igaz, hogy $\operatorname{dim} \operatorname{lin}\left\{a_{1}, a_{2}\right\}=2$. 
26.10 Definíció. Valamely $a_{1}, \ldots, a_{k}$ vektorok által generált altér dimenzióját a vektorrendszer rangjának is nevezzük, jelölésben:

$$
\operatorname{rank}\left\{a_{1}, \ldots, a_{k}\right\}=\operatorname{dim} \operatorname{lin}\left\{a_{1}, \ldots, a_{k}\right\} .
$$

\subsection{Elemi bázistranszformáció}

Ebben a szakaszban egy nagyon egyszerű és széleskörúen használható eljárást mutatunk be, amellyel gyorsan ellenőrizhető, hogy egy adott vektorrendszer lineárisan független-e.

Tekintsünk az $\mathbb{R}^{n}$ vektortérben egy $a$ vektort, amely a standard bázissal az

$$
a=\alpha_{1} e_{1}+\ldots+\alpha_{n} e_{n}
$$

alakban írható fel. Tekintsünk egy másik $b$ vektort is, amelynek előállítása

$$
b=\beta_{1} e_{1}+\ldots+\beta_{n} e_{n} \text { ahol } \beta_{1} \neq 0 .
$$

KÉRDÉS: Milyen lineáris kombinációval adható meg az a vektor, ha a standard bázis helyett a $b, e_{2}, \ldots, e_{n}$ bázist tekintjük, azaz az $e_{1}$ vektort a $b$ vektorra cseréljük?

MEGJEGYZÉS: Könnyen látható, hogy a $\beta_{1} \neq 0$ feltétel miatt a $b, e_{2}, \ldots, e_{n}$ rendszer bázis, hiszen egyrészt $n$-elemú, másrészt független a többi vektortól (hiszen $b$ előállításához szükség van az $e_{1}$ vektorra is).

Fejezzük ki az $e_{1}$ vektort a 26.2 egyenlőségből:

$$
e_{1}=\frac{1}{\beta_{1}} b-\frac{\beta_{2}}{\beta_{1}} e_{2}-\ldots-\frac{\beta_{n}}{\beta_{1}} e_{n}
$$

majd helyettesítsük ezt be $e_{1}$ helyére a 26.1 egyenlőségbe. Rendezés után azt kapjuk, hogy

$$
a=\frac{\alpha_{1}}{\beta_{1}} b+\left(\alpha_{2}-\frac{\alpha_{1}}{\beta_{1}} \beta_{2}\right) e_{2}+\ldots+\left(\alpha_{n}-\frac{\alpha_{1}}{\beta_{1}} \beta_{n}\right) e_{n} .
$$

Ez az eljárás, amelyet elemi bázistranszformációnak nevezünk, megadja az a vektor előállítását az új $b, e_{2}, \ldots, e_{n}$ bázisban.

26.11 Példa. Az elemi bázistranszformáció használatával vizsgáljuk meg, hogy az

$$
a=\left[\begin{array}{r}
1 \\
-1 \\
2
\end{array}\right] \quad b=\left[\begin{array}{r}
2 \\
1 \\
-1
\end{array}\right] \quad c=\left[\begin{array}{r}
3 \\
3 \\
-4
\end{array}\right]
$$


vektorok lineárisan függetlenek-e. Az eljárás a következő:

$$
\left|\begin{array}{rrr|rr|r}
1 & 2 & 3 & 2 & 3 & -1 \\
-1 & 1 & 3 & 3 & 6 & 2 \\
2 & -1 & -4 & -5 & -10 & 0
\end{array}\right|
$$

Ez a számolás azt mutatja, hogy a vektorok nem lineárisan függetlenek, nevezetesen a $c$ vektor kifejezhetô az $a$ és $b$ vektorok segítségével, éspedig $c=-a+2 b$. Ekkor az $a, b, c$ vektorrendszer rangja 2 , azaz

$$
\operatorname{dim} \operatorname{lin}\{a, b, c\}=2 .
$$

26.12 Példa. Tekintsük az $\mathbb{R}^{4}$ tér következő vektorait

$$
a_{1}=\left[\begin{array}{r}
1 \\
0 \\
-1 \\
2
\end{array}\right] \quad a_{2}=\left[\begin{array}{r}
2 \\
1 \\
0 \\
-1
\end{array}\right] \quad a_{3}=\left[\begin{array}{r}
-1 \\
-2 \\
-3 \\
8
\end{array}\right] \quad a_{4}=\left[\begin{array}{l}
1 \\
1 \\
1 \\
3
\end{array}\right]
$$

és határozzuk meg, hogy az $\mathbb{R}^{4}$ vektortérben hány dimenziós az $a_{1}, a_{2}, a_{3}, a_{4}$ vektorok által generált

$$
M=\operatorname{lin}\left\{a_{1}, a_{2}, a_{3}, a_{4}\right\}
$$

altér!

Végezzük el az elemi bázistranszformációt a megadott vektorokra, akkor azt kapjuk, hogy

$$
\left|\begin{array}{rrrr|rrr|rr}
1 & 2 & -1 & 1 & 2 & -1 & 1 & 3 & -1 \\
0 & 1 & -2 & 1 & 1 & -2 & 1 & -2 & 1 \\
-1 & 0 & -3 & 1 & 2 & -4 & 2 & 0 & 0 \\
2 & -1 & 8 & -3 & -5 & 10 & -5 & 0 & 0
\end{array}\right|
$$

Innen azt láthatjuk, hogy az $a_{3}$ és $a_{4}$ vektorok lineárisan függnek az $a_{1}$ és $a_{2}$ vektoroktól, nevezetesen

$$
a_{3}=3 a_{1}-2 a_{2}
$$

illetve

$$
a_{4}=-a_{1}+a_{2}
$$

Tehát az $a_{1}, a_{2}, a_{3}, a_{4}$ vektorrendszerben csak két lineárisan független vektor van $a_{1}$ és $a_{2}$. Innen adódik, hogy

$$
\operatorname{dim} M=\operatorname{dim} \operatorname{lin}\left\{a_{1}, a_{2}, a_{3}, a_{4}\right\}=2 .
$$




\section{Otthoni tanuláshoz}

1. A Feladatgyújtemény-1 II/3 szakasza kidolgozott példáinak feldolgozása.

2. Házi feladatok: a II/3 szakasz 3.1.4, 3.1.5, 3.2.4, 3.2.5, 3.3.2 , 3.3.5 feladatai.

3. Tankönyv-1 14.1 szakasza. 


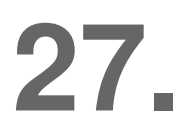

\section{LINEÁRIS LEKÉPEZÉSEK ÉS MÁTRIXOK}





\subsection{Lineáris leképezések}

Legyenek $n$ és $m$ természetes számok, és tekintsük az $\mathbb{R}^{n}$ és $\mathbb{R}^{m} n$, illetve $m$-dimenziós vektortereket.

27.1 Definíció. Az $A: \mathbb{R}^{n} \rightarrow \mathbb{R}^{m}$ leképezést lineáris leképezésnek nevezzük, ha

- $A(x+y)=A x+A y$

- $A(\alpha x)=\alpha A x$

bármely $x, y \in \mathbb{R}^{n}$ vektorok és $\alpha \in \mathbb{R}$ skalár esetén.

Ha $n=m$, azaz a leképezés a vektorteret önmagába képezi, akkor lineáris transzformációról beszélünk.

Könnyen ellenőrizhetjük egy lineáris leképezés következő tulajdonságait:

- $A(\alpha x+\beta y)=\alpha A x+\beta A y$ bármely $x, y$ vektorokra és $\alpha, \beta$ skalárokra.

- $A 0=0$, azaz a 0 vektor képe mindig a 0 vektor.

27.2 Példa. Az alábbiakban megadunk olyan leképezéseket, amelyek az $\mathbb{R}^{2}$ síkot önmagába képezik.

1. Legyen $A$ az a leképezés, amely bármely $x$ vektorhoz a $\lambda$-szorosát rendeli, azaz $A x=\lambda x$.

2. Legyen $A$ az a leképezés, amely bármely $x$ vektorhoz a vízszintes tengelyre vonatkozó tükörképét rendeli.

3. Legyen $A$ az a leképezés, amely bármely vektorhoz az $y=x 45^{\circ}$-os egyenesre vonatkozó vetületét rendeli.

4. Legyen $A$ az a leképezés, amely bármely $x$ vektorhoz az origó körül $\varphi$ szöggel pozitív irányba történő elforgatottját rendeli.

Mutassuk meg, hogy a fenti példák mindegyikében $A$ az $\mathbb{R}^{2}$ sík egy lineáris transzformációját definiálja, azaz kielégíti a definíció két egyenlőségét. Készítsünk ábrákat! 


\subsection{Leképezések mátrixa}

Az alábbiakban azt vizsgáljuk meg, hogy ha egy lineáris leképezés esetén ismerjük a bázisvektorok képeit, akkor már tetszőleges vektor képét elő tudjuk állítani.

Legyen ugyanis $A: \mathbb{R}^{n} \rightarrow \mathbb{R}^{m}$ lineáris leképezés, továbbá legyen $e_{1}, \ldots, e_{n}$ a standard bázis az $\mathbb{R}^{n}$ vektortérben. Ha most $x \in \mathbb{R}^{n}$ egy tetszőleges vektor, akkor $x$ felírható a standard bázis lineáris kombinációjaként:

$$
x=x_{1} e_{1}+\ldots+x_{n} e_{n} .
$$

Alkalmazzuk mindkét oldalra az A leképezést, akkor a linearitás tulajdonságát felhasználva

$$
A x=x_{1} A e_{1}+\ldots+x_{n} A e_{n},
$$

azaz $A x$ megadásához csak az $A e_{1}, \ldots, A e_{n}$ vektorokra van szükség.

Tegyük fel ezért, hogy $f_{1}, \ldots, f_{m}$ a standard bázis az $\mathbb{R}^{m}$ vektortérben, és írjuk fel az $A e_{1}, \ldots, A e_{n}$ vektorokat a bázis lineáris kombinációiként ebben a térben:

$$
\begin{aligned}
A e_{1} & =a_{11} f_{1}+a_{21} f_{2}+\ldots+a_{m 1} f_{m} \\
A e_{2} & =a_{12} f_{1}+a_{22} f_{2}+\ldots+a_{m 2} f_{m} \\
& \vdots \\
A e_{n} & =a_{1 n} f_{1}+a_{2 n} f_{2}+\ldots+a_{m n} f_{m}
\end{aligned}
$$

Ezekben az egyenlőségekben álló együtthatókat egy táblázatba gyưjtve az alábbi $m \times n$ es mátrixhoz, jutunk, amelyet az A leképezés mátrixának nevezünk.

$$
A=\left[\begin{array}{rrrr}
a_{11} & a_{12} & \ldots & a_{1 n} \\
a_{21} & a_{22} & \ldots & a_{2 n} \\
& \vdots & & \\
a_{m 1} & a_{m 2} & \ldots & a_{m n}
\end{array}\right]
$$

amelynek $m$ sora és $n$ oszlopa van. A mátrix $j$-ik oszlopa az $A e_{j}$ eleőállítása az $\mathbb{R}^{m}$ tér $f_{1}, \ldots, f_{m}$ bázisában. Ezáltal egy $x$ vektor $A x$ képét úgy állíthatjuk elő, hogy az $A$ mátrixát megszorozzuk az $x$ vektor koordinátáival az alábbi módon:

$$
A x=\left[\begin{array}{cccc}
a_{11} & a_{12} & \ldots & a_{1 n} \\
a_{21} & a_{22} & \ldots & a_{2 n} \\
& & \vdots & \\
a_{m 1} & a_{m 2} & \ldots & a_{m n}
\end{array}\right] \cdot\left[\begin{array}{c}
x_{1} \\
x_{2} \\
\vdots \\
x_{n}
\end{array}\right]=\left[\begin{array}{c}
a_{11} x_{1}+\ldots+a_{1 n} x_{n} \\
a_{21} x_{1}+\ldots+a_{2 n} x_{n} \\
\vdots \\
a_{m 1} x_{1}+\ldots+a_{m n} x_{n}
\end{array}\right]
$$

azaz, az $A x$ szorzat egy $m$-koordinátájú $\mathbb{R}^{m}$ térbeli vektor lesz. 
Világos, hogy minden lineáris leképezés az adott bázisban mátrix-alakban írható fel. Ugyanakkor fordítva, az is világos, hogy a 27.1 egyenlőséggel a vektortéren egy lineáris leképezést értelmezünk. Tehát kölcsönösen egyértelmú megfeleltetést találtunk a lineáris leképezések és a mátrixok között.

FIGYELEM! A továbbiakban nem teszünk különbséget a lineáris leképezések és mátrixaik között.

27.3 Példa. Tekintsük a 27.2 Példában értelmezett lineáris transzformációkat, akkor azok mátrixai sorrendben:

$$
\begin{aligned}
\text { 1. } A & =\left[\begin{array}{ll}
\lambda & 0 \\
0 & \lambda
\end{array}\right] \quad \text { 2. } A=\left[\begin{array}{rr}
1 & 0 \\
0 & -1
\end{array}\right] \quad \text { 3. } A=\left[\begin{array}{rr}
1 / 2 & 1 / 2 \\
1 / 2 & 1 / 2
\end{array}\right] \\
\text { 4. } A & =\left[\begin{array}{rr}
\cos \varphi & -\sin \varphi \\
\sin \varphi & \cos \varphi
\end{array}\right]
\end{aligned}
$$

Készítsünk ábrát, és azon ellenőrizzük!

\subsection{Mátrix rangja és szabadságfoka}

27.4 Definíció. Tekintsünk egy $A: \mathbb{R}^{n} \rightarrow \mathbb{R}^{m}$ lineáris leképezést (azaz $m \times n$-es mátrixot). Az A értékészletét

$$
\operatorname{im} A=\left\{y \in \mathbb{R}^{m}: \text { van olyan } x \in \mathbb{R}^{n} \text {, hogy } y=A x\right\}
$$

az A képterének, míg a

$$
\operatorname{ker} A=\left\{x \in \mathbb{R}^{n}: A x=0\right\}
$$

halmazt az $A$ magterének nevezzük. Világos, hogy $\operatorname{ker} A$, illetve $\operatorname{im} A$ egyaránt alterek az $\mathbb{R}^{n}$ illetve $\mathbb{R}^{m}$ vektorterekben.

A definíció szerint az $\operatorname{im} A$ altér nem más, mint azon vektorok altere, amelyek kifejezhetôk az $A$ oszlopainak lineáris kombinációiként. Ha tehát $a_{1}, \ldots, a_{n}$ jelölik az $A$ oszlopvektorait, akkor

$$
\operatorname{im} A=\operatorname{lin}\left\{a_{1}, \ldots, a_{n}\right\} .
$$

Teljesen hasonlóan a $\operatorname{ker} A$ altér azon $x$ vektorokból áll, amelyekre

$$
A x=x_{1} a_{1}+\ldots+x_{n} a_{n}=0,
$$

ahol $x_{1}, \ldots, x_{n}$ az $x$ vektor koordinátáit jelentik.

27.5 Példa. Tekintsük például a következő $A$ mátrixot:

$$
A=\left[\begin{array}{rrr}
1 & 3 & 1 \\
-2 & 1 & 5 \\
2 & 2 & -2
\end{array}\right]
$$


és oszlopait jelölje rendre $a_{1}, a_{2}$ és $a_{3}$. Elemi bázistranszformációval láthatjuk, hogy az oszlopok nem függetlenek, hiszen $a_{3}=-2 a_{1}+a_{2}$. Ezért $A$ képtere, azaz az oszlopvektorok által generált altér:

$$
\operatorname{im} A=\operatorname{lin}\left\{a_{1}, a_{2}\right\} .
$$

Másrészt az előző egyenlőséget rendezve azt kapjuk, hogy

$$
-2 a_{1}+a_{2}-a_{3}=0 .
$$

Ez azt mutatja, hogy

$$
\operatorname{ker} A=\operatorname{lin}\left\{\left[\begin{array}{r}
-2 \\
1 \\
-1
\end{array}\right]\right\}=\left\{t \cdot\left[\begin{array}{r}
-2 \\
1 \\
-1
\end{array}\right] \in \mathbb{R}^{3}: t \in \mathbb{R}\right\},
$$

azaz mindezen vektorokat $A$-val szorozva a nulla vektort kapjuk.

27.6 Definíció. Az $A m \times n$-es mátrix rangján a képtér dimenzióját értjük:

$$
\operatorname{rank} A=\operatorname{dimim} A
$$

azaz az $A$ lineárisan független oszlopainak maximális számát. Az A szabadságfoka

$$
\operatorname{deg} A=\operatorname{dim} \operatorname{ker} A .
$$

Például a 27.5Példában vizsgált $A$ mátrix esetében $\operatorname{rank} A=2$ és $\operatorname{deg} A=1$.

27.7 Tétel. Bármely $A m \times n$-es mátrixra $\operatorname{rank} A+\operatorname{deg} A=n$

Bizonyítás. Legyenek $a_{1}, \ldots, a_{k}$ a $\operatorname{ker} A$ altér, illetve $A b_{1}, \ldots, A b_{m}$ az im $A$ altér bázisvektorai. Megmutatjuk, hogy az

$$
a_{1}, \ldots, a_{k}, b_{1}, \ldots, b_{m}
$$

vektorok együttesen az $\mathbb{R}^{n}$ tér bázisát adják. Egyrészt lineárisan függetlenek, mert az

$$
\alpha_{1} a_{1}+\ldots+\alpha_{k} a_{k}+\beta_{1} b_{1}+\ldots+\beta_{m} b_{m}=0
$$

egyenlőséget $A$-val szorozva a

$$
\beta_{1} A b_{1}+\ldots+\beta_{m} A b_{m}=0
$$

egyenlőséghez jutunk, és innen $\beta_{1}=\ldots=\beta_{m}=0$ adódik. Ebből következik, hogy $\alpha_{1}=\ldots=\alpha_{k}=0$. 
Másrészt generátorrendszert is alkotnak, ugyanis, ha $x \in \mathbb{R}^{n}$ tetszőleges, akkor $A x \in$ $\operatorname{im} A$, és így kifejezhető az $A b_{1}, \ldots, A b_{m}$ vektorokkal:

$$
A x=\beta_{1} A b_{1}+\ldots+\beta_{m} A b_{m}
$$

Ekkor $x-\left(\beta_{1} b_{1}+\ldots+\beta_{m} b_{m}\right) \in \operatorname{ker} A$, ezért kifejezhető az $a_{1}, \ldots, a_{k}$ vektorok lineáris kombinációjával, azaz

$$
x-\left(\beta_{1} b_{1}+\ldots+\beta_{m} b_{m}\right)=\alpha_{1} a_{1}+\ldots+\alpha_{k} a_{k}
$$

Következésképpen $k+m=n$.

\subsection{Mátrixok szorzása}

Tekintsük az alábbiakban az $A: \mathbb{R}^{n} \rightarrow \mathbb{R}^{m}$ és $B: \mathbb{R}^{m} \rightarrow \mathbb{R}^{k}$ lineáris leképezéseket. Ekkor képezhetjük a $B \circ A: \mathbb{R}^{n} \rightarrow \mathbb{R}^{k}$ kompozíció leképezést, amelyet lineáris leképezések esetén szorzatként jelölünk:

$$
B A=B \circ A
$$

Könnyű ellenôrizni, hogy $B A: \mathbb{R}^{n} \rightarrow \mathbb{R}^{k}$ is lineáris leképezés, tehát a standard bázisban a mátrixa $k \times n$ méretû. Vajon hogyan állítható elő ez a mátrix?

Valamelyik $j$ indexre tekintsük az $A e_{j}$ vektor képét a $B$ leképezésnél, azaz a $B\left(A e_{j}\right)$ vektort. Ennek a vektornak az $i$-ik koordinátája:

$$
b_{i 1} a_{1 j}+\ldots+b_{i m} a_{m j}
$$

ami a $B A$ szorzatmátrix $i$-ik sorában és $j$-ik oszlopában álló elem lesz. Tehát a két mátrixot úgy szorozzuk össze, hogy $B$ sorait a fenti szabály szerint megszorozzuk $A$ oszlopaival.

FIGYELEM! A sorrend fontos, a $B A$ szorzat nem egyezik meg $A B$-vel, sốt előfordulhat, hogy a fordított sorrend nincs is értelmezve!

27.8 Példa. A fenti szabály szerint ellenőrizzük a következő mátrixszorzást:

$$
\left[\begin{array}{rrrr}
2 & 3 & 1 & 0 \\
-1 & 0 & 2 & 1 \\
1 & 1 & -1 & 1
\end{array}\right] \cdot\left[\begin{array}{rrr}
-1 & 2 & -4 \\
1 & -1 & 1 \\
0 & 3 & -2 \\
1 & 1 & 0
\end{array}\right]=\left[\begin{array}{rrr}
1 & 4 & -7 \\
2 & 5 & -1 \\
1 & -1 & -1
\end{array}\right]
$$

azaz a szorzatmátrix $3 \times 3$ méretû. 
27.9 Példa. Tekintsük az $\alpha$ paraméterrel megadott

$$
A=\left[\begin{array}{rrr}
1 & 2 & 5 \\
2 & -1 & 0 \\
-3 & 1 & \alpha
\end{array}\right]
$$

mátrixot, és határozzuk meg a rangját és szabadságfokát. Elemi bázistranszformációval

$$
\left|\begin{array}{rrr|rr|r}
1 & 2 & 5 & 2 & 5 & 1 \\
2 & -1 & 0 & -5 & -10 & 2 \\
-3 & 1 & \alpha & 7 & \alpha+15 & \alpha+1
\end{array}\right|
$$

Innen azt a következtetést vonhatjuk le, hogy

$$
\operatorname{rank} A= \begin{cases}3 & \text { ha } \alpha \neq-1 \\ 2 & \text { ha } \alpha=-1\end{cases}
$$

és ennek megfelelően, a 27.7 Tétel értelmében

$$
\operatorname{deg} A= \begin{cases}0 & \text { ha } \alpha \neq-1 \\ 1 & \text { ha } \alpha=-1\end{cases}
$$

\section{Otthoni tanuláshoz}

1. A Feladatgyújtemény-1 II/2 és II/3 szakaszai kidolgozott példáinak feldolgozása.

2. Házi feladatok: a II/2 szakasz 2.1.2, 2.1.3, továbbá a II/3 szakasz 3.4.4, 3.4.6, 3.4.7, 3.4.8, 3.5.2, 3.6.2, 3.7.6, 3.7.7 feladatai.

3. Tankönyv-1 12.6, 12.7, 12.8 és 14.2 szakaszai. 



\subsection{Homogén lineáris egyenletrendszerek}

Homogén lineáris egyenletrendszeren az alábbi rendszert értjük:

$$
\begin{aligned}
a_{11} x_{1}+\ldots+a_{1 n} x_{n} & =0 \\
& \vdots \\
a_{m 1} x_{1}+\ldots+a_{m n} x_{n} & =0
\end{aligned}
$$

ahol az $a_{i j}$ együtthatók adott valós számok. Megoldandó az egyenletrendszer az $x_{1}, \ldots, x_{n}$ ismeretlenekre.

Ha összeállítjuk az együtthatók $A$ mátrixát és az ismeretlenek $x$ vektorát a következő módon:

$$
A=\left[\begin{array}{ccc}
a_{11} & \ldots & a_{1 n} \\
& \vdots & \\
a_{m 1} & \ldots & a_{m n}
\end{array}\right] \quad x=\left[\begin{array}{r}
x_{1} \\
\vdots \\
x_{n}
\end{array}\right]
$$

akkor a fenti homogén rendszer a következô egyszerú alakban írható fel:

$$
A x=0
$$

amely megoldásainak halmaza éppen a $\operatorname{ker} A$ altér. Az $x=0$ vektor mindig megoldás, ha nem ez az egyetlen, akkor végtelen sok megoldás van.

28.1 Példa. Állítsuk elő az alábbi homogén lineáris egyenletrendszer általános megoldását (azaz az összes megoldást).

$$
\begin{aligned}
x_{1}+3 x_{2}-3 x_{3} & =0 \\
2 x_{1}+x_{2}+4 x_{3} & =0 \\
x_{1}+2 x_{2}-x_{3} & =0
\end{aligned}
$$

Ekkor az egyenletrendszer együttható-mátrixa

$$
A=\left[\begin{array}{rrr}
1 & 3 & -3 \\
2 & 1 & 4 \\
1 & 2 & -1
\end{array}\right]
$$

és az egyenletrendszer az $A x=0$ alakban írható fel. Alkalmazzuk az $A$ mátrixra az elemi bázistranszformációt:

$$
\left|\begin{array}{rrr|rr|r}
\hline 1 & 3 & -3 & 3 & -3 & 3 \\
2 & 1 & 4 & -5 & 10 & -2 \\
1 & 2 & -1 & -1 & 2 & 0
\end{array}\right|
$$


Ez azt jelenti, hogy $A$ oszlopai lineárisan összefüggók, az oszlopokat az $a_{1}, a_{2}, a_{3}$ vektorokkal jelölve

$$
a_{3}=3 a_{1}-2 a_{2}, \quad \text { azaz } 3 a_{1}-2 a_{2}-a_{3}=0 .
$$

Ezért $x_{1}=3, x_{2}=-2$ és $x_{3}=-1$ nyilvánvalóan megoldást szolgáltatnak, az általános megoldás pedig az

$$
x=t \cdot\left[\begin{array}{r}
3 \\
-2 \\
-1
\end{array}\right], \quad t \in \mathbb{R}
$$

alakban adható meg. Világos, hogy ebben az esetben

$$
\operatorname{deg} A=1 \quad \text { és } \operatorname{rank} A=2 \text {. }
$$

\subsection{Inhomogén lineáris egyenletrendszerek}

Tekintsük az $A m \times n$-es mátrixot, és legyen $b \in \mathbb{R}^{m}$ adott nem nulla vektor. Ekkor az

$$
A x=b
$$

rendszert inhomogén lineáris egyenletrendszernek nevezzük.

28.2 Állítás. A 28.2 rendszer akkor és csak akkor megoldható, ha $b \in \operatorname{im} A$, azaz a b vektor elóállítható az A oszlopainak lineáris kombinációjaként.

A rendszer megoldása csak akkor egyértelmü, ha az A oszlopai lineárisan függetlenek, azaz a szabadságfoka nulla.

Bizonyítás. Csak az egyértelmúséget kell igazolnunk. Indirekt módon, ha lenne két különböző megoldás, $x$ és $y$, akkor

$$
A(x-y)=A x-A y=b-b=0,
$$

ekkor azonban $A$ oszlopai lineárosan összefüggők.

Tegyük fel, hogy ismerjük az inhomogén rendszer valamely $\bar{x}$ partikuláris megoldását. Ekkor a rendszer bármely megoldását előállíthatjuk a homogén rendszer megoldásainak ismeretében. Ezt fogalmazza meg a következő tételünk.

28.3 Tétel. Legyen $\bar{x}$ az inhomogén rendszer valamely megoldása. Ekkor az inhomogén rendszer bármely megoldása elóállítható az.

$$
x=\bar{x}+x_{0}
$$

alakban, ahol $x_{0}$ a homogén rendszer valamely megoldása. Fordítva, ha $x_{0}$ a homogén rendszer tetszóleges megoldása, akkor $\bar{x}+x_{0}$ kielégíti az inhomogén rendszert. 
Bizonyítás. Valóban, ha $x$ az inhomogén rendszer valamely megoldása, akkor tekintsük az $x_{0}=x-\bar{x}$ vektort. Erre a vektorra

$$
A x_{0}=A(x-\bar{x})=A x-A \bar{x}=b-b=0,
$$

azaz $x_{0}$ kielégíti a homogén rendszert, és $x=\bar{x}+x_{0}$.

Fordítva, ha $x_{0}$ a homogén rendszer egy tetszőleges megoldása, akkor az $x=\bar{x}+x_{0}$ vektorra

$$
A x=A\left(\bar{x}+x_{0}\right)=A \bar{x}+A x_{0}=b+0=b,
$$

azaz $x$ az inhomogén rendszer megoldását adja.

28.4 Példa. Adjuk meg az alábbi inhomogén rendszer általános megoldását:

$$
\begin{aligned}
x_{1}-x_{2}+3 x_{3}+3 x_{4} & =1 \\
x_{1}-2 x_{2}+x_{3}-x_{4} & =4 \\
2 x_{1}+x_{2}-x_{3}+5 x_{4} & =6 .
\end{aligned}
$$

Ekkor a korábbi jelöléseinket használva

$$
A=\left[\begin{array}{rrrr}
1 & -1 & 3 & 3 \\
1 & -2 & 1 & -1 \\
2 & 1 & -1 & 5
\end{array}\right] \quad \text { és } \quad b=\left[\begin{array}{l}
1 \\
4 \\
6
\end{array}\right]
$$

Mivel az $A$ mátrixnak 3 sora és 4 oszlopa van, ezért a szabadságfoka legalább 1, azaz a megoldás biztosan nem lesz egyértelmú. Elemi bázistranszformációval

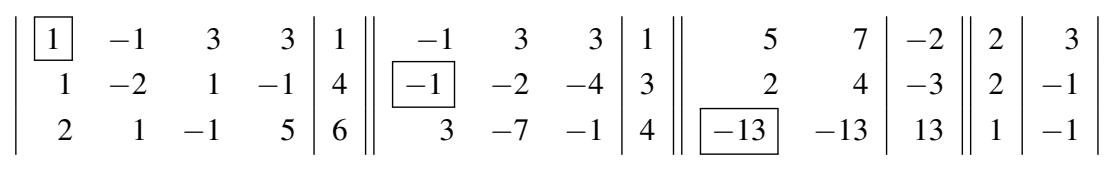

Tehát az $A$ mátrix rangja 3, és a szabadságfoka 1 . Ha az $A$ mátrix oszlopaira rendre az $a_{1}, a_{2}, a_{3}, a_{4}$ jelölést használjuk, akkor ez a számolás azt mutatja (lásd az utolsó két oszlopot), hogy

$$
a_{4}=2 a_{1}+2 a_{2}+a_{3} \quad \text { továbbá } \quad b=3 a_{1}-a_{2}-a_{3} .
$$

Igy megadhatjuk az inhomogén rendszer és a homogén rendszer egy-egy megoldását:

$$
\bar{x}=\left[\begin{array}{r}
3 \\
-1 \\
-1 \\
0
\end{array}\right] \quad \text { és } \quad x_{0}=\left[\begin{array}{r}
2 \\
2 \\
1 \\
-1
\end{array}\right]
$$

Tehát a fenti tételünk értelmében az inhomogén rendszer általános megoldása:

$$
x=\bar{x}+t \cdot x_{0}=\left[\begin{array}{r}
3 \\
-1 \\
-1 \\
0
\end{array}\right]+t \cdot\left[\begin{array}{r}
2 \\
2 \\
1 \\
-1
\end{array}\right] \quad t \in \mathbb{R} .
$$


28.5 Példa. Tekintsük az $\alpha$ és $\beta$ valós paraméterekkel megadott $A x=b$ inhomogén rendszert, ahol

$$
A=\left[\begin{array}{rrr}
1 & -1 & 0 \\
2 & 1 & 3 \\
-1 & 1 & \alpha
\end{array}\right] \quad \text { és } \quad b=\left[\begin{array}{l}
1 \\
2 \\
\beta
\end{array}\right]
$$

Vizsgáljuk meg, hogy a paraméterek milyen értékei mellett oldható meg az egyenletrendszer. Végezzük el az elemi bázistranszformációt:

$$
\left|\begin{array}{rrr|r||rr|r||r|r}
1 & -1 & 0 & 1 \\
2 & 1 & 3 & 2 \\
-1 & 1 & \alpha & \beta & -1 & 0 & 1 & 1 & 1 \\
3 & 3 & 0 & 1 & 0 \\
0 & \alpha & \beta+1 & \alpha & \beta+1
\end{array}\right|
$$

Ennek alapján az alábbi következtetést vonhatjuk le:

- pontosan egy megoldás van, ha $\alpha \neq 0$ és $\beta$ tetszőleges

- végtelen sok megoldás van, ha $\alpha=0$ és $\beta=-1$

- nincs megoldás, ha $\alpha=0$ és $\beta \neq-1$

Az A mátrix rangjára és szabadságfokára az adódik, hogy

$$
\operatorname{rank} A= \begin{cases}3 & \text { ha } \alpha \neq 0 \\ 2 & \text { ha } \alpha=0\end{cases}
$$

illetve

$$
\operatorname{deg} A= \begin{cases}0 & \text { ha } \alpha \neq 0 \\ 1 & \text { ha } \alpha=0\end{cases}
$$

\subsection{Inverz mátrix}

Jelölje $E$ azt az $n \times n$ méretû mátrixot, amelynek fődiagonálisában minden elem 1, azon kívül minden elem 0 . Ezt a mátrixot $n \times n$-es egységmátrixnak nevezzük. Világos, hogy $E$ mint lineáris leképezés, az identikus leképezés, hiszen minden $x$ vektorra $E x=x$.

28.6 Definíció. Tekintsünk egy $n \times n$-es $A$ négyzetes mátrixot. Azt mondjuk, hogy $A$ invertálható, ha van olyan $n \times n$-es $A^{-1}$ mátrix, amelyre

$$
A \cdot A^{-1}=E .
$$

Ezt az $A^{-1}$ mátrixot az $A$ inverzének nevezzük. 
Könnyen látható, hogy $A^{-1}$ az inverz leképezés, azaz $A A^{-1} x=x$ minden $x \in \mathbb{R}^{n}$ esetén. Az is világos, hogy ilyenkor $A^{-1} A=E$ is érvényes.

Az inverz létezésének szükséges és elégséges feltétele, hogy a leképezés kölcsönösen egyértelmú legyen. Ezen az észrevételen alapul a következő tétel.

28.7 Tétel. Egy A $n \times n$-es mátrixra a következó állítások ekvivalensek:

1. A invertálható

2. az A oszlopai lineárisan függetlenek

3. $\operatorname{ker} A=\{0\}$

4. $\operatorname{im} A=\mathbb{R}^{n}$

5. $\operatorname{rank} A=n$

6. $\operatorname{deg} A=0$.

A páronkénti ekvivalenciák ellenőrzése helyett az ilyen állításokat a matematikában úgy szokták bizonyítani, hogy sorrendben igazoljuk a következő implikációkat:

$$
1 \Rightarrow 2 \Rightarrow 3 \Rightarrow 4 \Rightarrow 5 \Rightarrow 6 \Rightarrow 1
$$

Gondoljuk végig, hogy ezek az implikációk valóban könnyen ellenőrizhetők, és ezekből valóban következik a fenti állítások ekvivalenciája.

Invertálható mátrixok esetében az inhomogén lineáris egyenletrendszerek megoldását nagyon egyszerúen lehet megadni.

28.8 Tétel. Legyen A $n \times n$-es invertálható mátrix. Akkor az,

$$
A x=b
$$

inhomogén lineáris egyenletrendszer egyértelmúen megoldható, és a megoldás az

$$
x=A^{-1} b
$$

alakban adható meg.

Érdemes megjegyezni, hogy ennek ellenére az egyenletrendszer megoldása az előzô szakaszban tanult elemi bázistranszformációval általában kevesebb számolással jár, mint az inverz meghatározása. Az inverz kiszámítása akkor előnyös, ha az inhomogén egyenletrendszert többször, más és más $b$ vektorral a rendszer jobb oldalán kell megoldani. 


\subsection{Az inverz mátrix meghatározása}

Tekintsünk egy $A n \times n$-es invertálható mátrixot. Az inverz mátrix meghatározását úgy képzeljük el, hogy keressük azt az $X n \times n$-es mátrixot, amelyre $A X=E$. Ha az ismeretlen $X$ mátrix oszlopait rendre $x_{1}, \ldots, x_{n}$ jelöli, akkor ez az $n$-számú

$$
A x_{k}=e_{k}
$$

$(k=1, \ldots, n)$ inhomogén lineáris egyenletrendszer megoldását jelenti. Ezt az eljárást az alábbi példán szemléltetjük (ahol egyszerre oldjuk meg az egyenletrendszereket).

28.9 Példa. Invertálható-e az alábbi $A$ mátrix? Ha igen, állítsuk elő az inverzét:

$$
A=\left[\begin{array}{lll}
1 & 1 & 1 \\
0 & 1 & 1 \\
1 & 0 & 1
\end{array}\right]
$$

$\mathrm{Az} A x=e_{1}, A x=e_{2}, A x=e_{3}$ egyenletrendszereket egyszerre megoldva:

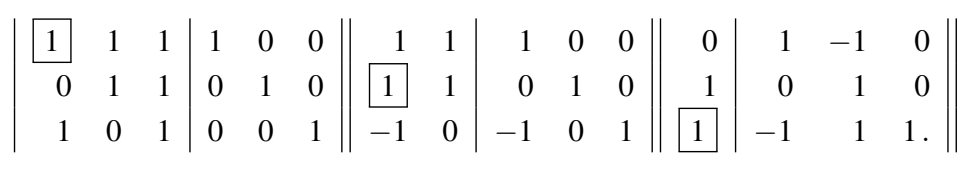

Ha a kijelölt elemi bázistranszformációt elvégezzük az utolsó három oszlopon, akkor azt kapjuk, hogy

$$
A^{-1}=\left[\begin{array}{rrr}
1 & -1 & 0 \\
1 & 0 & -1 \\
-1 & 1 & 1
\end{array}\right]
$$

amirôl közvetlen szorzással ellenôrizhetjük, hogy $A A^{-1}=E$, azaz valóban az $A$ inverze. 


\section{Otthoni tanuláshoz}

1. A Feladatgyứjtemény-1 II/4 és II/5 szakaszai kidolgozott példáinak feldolgozása.

2. Házi feladatok: a II/4 szakasz 4.1.5, 4.1.6, 4.2.2, 4.2.3, 4.3 .4 továbbá a II/5 szakasz 5.1.3, 5.2.2, 5.3.6, 5.3.7, 5.4.2 feladatai.

3. Tankönyv-1 12.1, 13.7 és 14.2 szakaszai. 

29.

SAJÁTÉRTÉK, SAJÁTVEKTOR 



\subsection{Sajátérték, sajátvektor}

29.1 Definíció. Tekintsük az $A: \mathbb{R}^{n} \rightarrow \mathbb{R}^{n}$ lineáris transzformációt, azaz $n \times n$-es mátrixot. Azt mondjuk, hogy a $\lambda$ szám az $A$ sajátértéke, ha van olyan $v \neq 0$ vektor, amelyre

$$
A v=\lambda v .
$$

Ilyenkor a $v$ vektort a $\lambda$ sajátértékhez tartozó sajátvektornak nevezzük.

29.2 Példa. Tekintsük például az $\mathbb{R}^{3}$ tér alábbi $A$ transzformációját és a v vektort, ahol

$$
A=\left[\begin{array}{rrr}
2 & 1 & -1 \\
0 & 1 & 1 \\
2 & 0 & -2
\end{array}\right] \quad \text { és } \quad v=\left[\begin{array}{l}
2 \\
1 \\
1
\end{array}\right]
$$

ekkor könnyen ellenőrizhető, hogy

$$
A v=2 v
$$

azaz $\lambda=2$ az $A$ sajátértéke, és $v$ egy hozzá tartozó sajátvektor. Az is látható, hogy az

$$
u=\left[\begin{array}{r}
1 \\
-1 \\
1
\end{array}\right]
$$

vektorra

$$
A u=0
$$

tehát $\lambda=0$ is sajátérték, és $u$ egy hozzá tartozó sajátvektor. Ellenôrizzük, hogy $\lambda=-1$ is az $A$ sajátértéke, és keressünk hozzá tartozó sajátvektort is!

FIGYELEM! Valamely $\lambda$ sajátértékhez tartozó sajátvektor soha nem egyértelmú. Gondoljuk meg, hogy ha $v$ sajátvektor, akkor annak bármely $\alpha v$ skalárszorosa is az. Valóban,

$$
A(\alpha v)=\alpha A v=\alpha \cdot \lambda v=\lambda(\alpha v)
$$

29.3 Példa. Vizsgáljuk most meg a 27.2 Példában ismertetett síkbeli transzformációkat.

1. Ha $A$ az $\alpha$-szoros nyújtás, akkor $\alpha$ az $A$ egyetlen sajátértéke, és a sík minden vektora sajátvektor.

2. Ha $A$ a vízszintes tengelyre vonatkozó tükrözés, akkor $\lambda_{1}=1$ sajátérték, és az $e_{1}$ vektor egy megfelelő sajátvektor, továbbá $\lambda_{2}=-1$ is sajátérték, és $e_{2}$ egy hozzá tartozó sajátvektor. 
3. Ha $A$ a $45^{\circ}$-os szögfelezőre történő merőleges vetítés, akkor a sajátértékek és a megfelelő sajátvektorok a következők:

$$
\lambda_{1}=1 \quad \text { és } \quad v_{1}=\left[\begin{array}{l}
1 \\
1
\end{array}\right] \quad \text { illetve } \quad \lambda_{2}=0 \quad \text { és } \quad v_{2}=\left[\begin{array}{r}
-1 \\
1
\end{array}\right]
$$

4. Ha $A$ az origó körüli $0 \leq \varphi<2 \pi$ szöggel történő elforgatás, akkor $\varphi=0$ esetén $\lambda=1$, míg $\varphi=\pi$ esetén $\lambda=-1$ az egyetlen sajátérték. Mindkét esetben a sík minden vektora sajátvektor.

Más $\varphi$ szögekre az $A$ elforgatásnak nincs valós sajátértéke.

\subsection{Sajátaltér}

29.4 Definíció. Tekintsük az $\mathbb{R}^{n}$ tér valamely $A$ lineáris transzformációját, és tegyük fel, hogy $\lambda$ az $A$ sajátértéke. Ekkor mindazon $v$ vektorok, amelyekre $A v=\lambda v$ alteret alkotnak, amelyet az $A$ transzformáció $\lambda$ sajátértékéhez tartozó sajátaltérnek nevezünk. Jelölésben

$$
S_{A}(\lambda)=\left\{v \in \mathbb{R}^{n}: A v=\lambda v\right\}
$$

29.5 Példa. Vizsgáljuk meg például a következő mátrixot

$$
A=\left[\begin{array}{lll}
1 & 0 & 0 \\
1 & 2 & 0 \\
0 & 0 & 2
\end{array}\right]
$$

Egyszerû számolással ellenôrizhetjük, hogy $\lambda=2$ az $A$ sajátértéke, és az $e_{2}, e_{3}$ vektorok egyaránt sajátvektorok, és lineárisan függetlenek.

Az is világos, hogy további független sajátvektorokat ehhez a sajátértékhez nem találhatunk, ezért a sajátaltérre

$$
\operatorname{dim} S_{A}(2)=2
$$

továbbá $e_{2}$ és $e_{3}$ ennek az altérnek a bázisát szolgáltatják. 


\subsection{Sajátvektorok meghatározása}

Tegyük fel ebben a szakaszban, hogy $A$ olyan $n \times n$-es mátrix, amelynek a $\lambda$ szám sajátértéke. Vajon hogyan határozható meg az összes megfelelő sajátvektor?

Jelölje $E$ az $n \times n$-es egységmátrixot, és tegyük fel, hogy $v$ valamelyik, a $\lambda$ sajátértékhez tartozó sajátvektor. Ekkor

$$
A v=\lambda v=\lambda E v
$$

illetve az egyenlőséget átrendezve

$$
(A-\lambda E) v=0
$$

tehát a $v$ vektorra egy homogén lineáris egyenletrendszer adódik. Fogalmazzuk meg tételben ezt az észrevételünket.

29.6 Tétel. Legyen A egy $n \times$-es mátrix, és $\lambda$ az A sajátértéke. Ekkor

$$
S_{A}(\lambda)=\operatorname{ker}(A-\lambda E)
$$

azaz a sajátaltér egy homogén lineáris egyenletrendszer általános megoldása.

Külön érdekes a $\lambda=0$ eset. Ha ugyanis ez sajátérték, akkor az $A v=0$ homogén lineáris egyenletrendszernek van nem nulla megoldása, azaz $A$ rangja nem lehet $n$. Ezt egy külön tételben is megfogalmazzuk.

29.7 Tétel. A akkor és csak akkor invertálható, ha $\lambda=0$ nem sajátérték.

Általában jóval nehezebb feladat azonban egy $A$ lineáris transzformáció sajátértékeinek megtalálása.

\subsection{Lineárisan független sajátvektorok}

Tekintsük az $A$ transzformációt az $\mathbb{R}^{n}$ téren, és tegyük fel, hogy a $\lambda_{1}, \ldots, \lambda_{k}$ különböző számok az $A$ sajátértékei, továbbá $v_{1}, \ldots, v_{k}$ az azonos indexú sajátértékekhez tartozó nem nulla sajátvektorok. Megmutatjuk, hogy ezek a vektorok lineárisan függetlenek.

29.8 Tétel. Különbözó sajátértékekhez tartozó nem nulla sajátvektorok lineárisan függetlenek. 
Bizonyítás. A tételt teljes indukcióval igazoljuk. Az állítás $k=1$-re nyilvánvaló. Tegyük fel, hogy az állítás $k-1$-ig igaz, és indirekt módon tegyük fel, hogy $v_{1}, \ldots, v_{k}$ összefüggók. Ezt jelenti, hogy van olyan lineáris kombinációjuk, amelyre

$$
\alpha_{1} v_{1}+\ldots+\alpha_{k} v_{k}=0
$$

de nem minden együttható nulla, pl. az egyszerúség kedvéért $\alpha_{1} \neq 0$. Alkalmazzuk mindkét oldalra az $A$ transzformációt, akkor

$$
\alpha_{1} A v_{1}+\ldots+\alpha_{k} A v_{k}=\alpha_{1} \lambda_{1} v_{1}+\ldots+\alpha_{k} \lambda_{k} v_{k}=0
$$

Ha ez utóbbi egyenlőségből kivonjuk a 29.1 egyenlőség $\lambda_{k}$-szorosát, akkor utolsó tag kiesik, és azt kapjuk, hogy

$$
\alpha_{1}\left(\lambda_{1}-\lambda_{k}\right) v_{1}+\ldots+\alpha_{k-1}\left(\lambda_{k-1}-\lambda_{k}\right) v_{k-1}=0 .
$$

Mivel a sajátértékek mind különbözőek, azért $\alpha_{1} \neq 0$ miatt itt a $v_{1}$ együtthatója nem nulla, ami azt jelentené, hogy a $v_{1}, \ldots, v_{k-1}$ vektorok lineárisan összefüggók. Ez azonban ellentmond az indukciós feltevésnek.

29.9 Példa. Tekintsük a 29.2 Példában vizsgált $A$ mátrixot. Egyszerú számolással láthatjuk, hogy $\lambda_{1}=2, \lambda_{2}=0$ és $\lambda_{3}=-1$ egyaránt az $A$ sajátértékei, és hozzájuk tartozó sajátvektorok rendre

$$
v_{1}=\left[\begin{array}{l}
2 \\
1 \\
1
\end{array}\right], \quad v_{2}=\left[\begin{array}{r}
1 \\
-1 \\
1
\end{array}\right] \quad \text { és } \quad v_{3}=\left[\begin{array}{r}
1 \\
-1 \\
2
\end{array}\right]
$$

Elemi bázistranszformációval könnyen ellenórizhetjük, hogy a $v_{1}, v_{2}, v_{3}$ vektorok valóban lineárisan függetlenek.

\subsection{Transzformációk diagonális alakja}

Egy mátrixot diagonális alakúnak nevezünk, ha a fődiagonálisan kívül csak nulla elemei vannak. Az ilyen mátrixok kezelése (pl. szorzás, hatványozás) igen egyszerû, ezért hasznosak lehetnek a lineáris algebrában, és az alkalmazásaiban is. Érdekes kérdés tehát, hogy egy adott mátrixhoz találhatunk-e olyan bázist, amelyben az diagonális alakú lesz. Látni fogjuk, hogy ez éppen a sajátvektorokból álló bázis (amennyiben ez létezik).

Tegyük fel, hogy az $n \times n$-es $A$ mátrix sajátértékei $\lambda_{1}, \ldots, \lambda_{n}$ (nem feltétlenül mind különbözőek), és a hozzájuk tartozó sajátvektorok $v_{1}, \ldots, v_{n}$, amelyekról tegyük fel, hogy lineárisan függetlenek. Mivel a számuk $n$, ezért ezek a vektorok ilyenkor az $\mathbb{R}^{n}$ bázisát alkotják. 
Irjuk most fel az $A$ transzformáció mátrixát a sajátvektorok bázisában. Jelölje $\hat{A}$ a mátrixot az új bázisban. Mivel a sajátvektorokra

$$
A v_{k}=\lambda v_{k} \quad k=1, \ldots, n
$$

azért $\hat{A}$ a következő alakot ölti:

$$
\hat{A}=\left[\begin{array}{ccc}
\lambda_{1} & \ldots & 0 \\
& \ddots & \\
0 & \ldots & \lambda_{n}
\end{array}\right]
$$

Vizsgáljuk meg, hogy milyen összefüggés van az $A$ transzformáció $e_{1}, \ldots, e_{n}$ bázisban, illetve a $v_{1}, \ldots, v_{n}$ bázisban felírt mátrixai között. Jelentse $S$ azt az $n \times n$ méretú mátrixot, amelynek oszlopai rendre a $v_{1}, \ldots, v_{n}$ sajátvektorok, azaz

$$
S e_{k}=v_{k}
$$

Világos, hogy $S$ invertálható, hiszen a feltételünk szerint az oszlopai lineárisan függetlenek. Továbbá

$$
A v_{k}=S \hat{A} e_{k}
$$

minden $k=1, \ldots, n$ esetén. Mindkét oldalt az $S^{-1}$ mátrix-szal szorozva

$$
S^{-1} A S e_{k}=\hat{A} e_{k}
$$

minden $k$ index mellett, ezért

$$
\hat{A}=S^{-1} A S
$$

Ezt az eredményünket a következő tételben foglaljuk össze.

29.10 Tétel. Tegyük fel, hogy A olyan $n \times n$-es mátrix, amelynek sajátértékei $\lambda_{1}, \ldots, \lambda_{n}$ és a hozzá tartozó $v_{1}, \ldots, v_{n}$ sajátvektorok a tér bázisát alkotják. Akkor a sajátvektorok bázisában A olyan Â diagonális alakú mátrix, amelynek fódiagonálisában a sajátértékek állnak, továbbá

$$
\hat{A}=S^{-1} A S
$$

ahol az S mátrix oszlopai a $v_{1}, \ldots, v_{n}$ sajátvektorok. 
29.11 Példa. Tekintsük újra a 29.2 Példában megadott $A$ transzformációt. Ekkor a $\lambda_{1}=2, \lambda_{2}=0$ és $\lambda_{3}=-1$ sajátértékekhez tartozó

$$
v_{1}=\left[\begin{array}{l}
2 \\
1 \\
1
\end{array}\right], \quad v_{2}=\left[\begin{array}{r}
1 \\
-1 \\
1
\end{array}\right] \quad \text { és } \quad v_{3}=\left[\begin{array}{r}
1 \\
-1 \\
2
\end{array}\right]
$$

sajátvektorok lineárisan függetlenek, ezért az $\mathbb{R}^{3}$ tér bázisát alkotják. Tehát a sajátvektorok által alkotott bázisban az $A$ transzformáció mátrixa diagonális alakú lesz. A tételünk szerint az

$$
S=\left[\begin{array}{rrr}
2 & 1 & 1 \\
1 & -1 & 1 \\
1 & -1 & 2
\end{array}\right] \quad \text { és } \hat{A}=\left[\begin{array}{rrr}
2 & 0 & 0 \\
0 & 0 & 0 \\
0 & 0 & -1
\end{array}\right]
$$

jelölésekkel

$$
\hat{A}=S^{-1} A S
$$

Ellenőrizzük ezt az egyenlőséget közvetlenül is, az $S^{-1}$ inverz mátrix meghatározásával, és a kijelölt mûveletek elvégzésével!

\section{Otthoni tanuláshoz}

1. A Feladatgyújtemény-1 II/6 szakasza kidolgozott példáinak feldolgozása.

2. Házi feladatok: a II/6 szakasz 6.4.1, 6.4.2, 6.4.3, 6.4.4, 6.4.5, 6.4.8, 6.4.9 és 6.4.10 feladatai.

3. Tankönyv-1 14.4 és 14.5 szakaszai. 
30.

DETERMINÁNS 



\subsection{Permutációk}

Tekintsük az első $n$ természetes szám $H=\{1, \ldots, n\}$ halmazát.

30.1 Definíció. Egy $p: H \rightarrow H$ kölcsönösen egyértelmú leképezést a $H$ halmaz permutációjának nevezünk.

Szemléletesen egy permutáció a $H$ halmaz elemeinek egy sorrendbe rakását jelenti. A $H$ halmaz összes permutációinak száma $n$ ! ( $n$ faktoriális).

30.2 Definíció. Tekintsük a $H$ halmaz valamely $p$ permutációját, amelyre

$$
p(1)=i_{1}, \quad \ldots \quad p(n)=i_{n}
$$

azaz az $\left\{i_{1}, \ldots, i_{n}\right\}$ sorrendet. Azt mondjuk, hogy az $i_{j}$ és $i_{k}$ elemek inverziót alkotnak, ha $j<k$ és $i_{j}>i_{k}$.

30.3 Példa. Például $n=5$ esetén az

$$
\{1,3,2,4,5\}
$$

egyetlen inverziót tartalmaz, míg a

$$
\{2,3,1,5,4\}
$$

sorrendben három inverzió található.

30.4 Definíció. A $H$ halmaz $p$ permutációját páratlannak nevezzük, ha az inverziók száma páratlan, ellenkező esetben a permutációt párosnak nevezzük. 


\subsection{A determináns fogalma}

Tekintsük a következő $n \times n$ méretű $A$ mátrixot

$$
A=\left[\begin{array}{rrrr}
a_{11} & a_{12} & \ldots & a_{1 n} \\
a_{21} & a_{22} & \ldots & a_{2 n} \\
\vdots & & & \\
a_{n 1} & a_{n 2} & \ldots & a_{n n}
\end{array}\right]
$$

30.5 Definíció. Az A mátrix determinánsán az alábbi kifejezést értjük:

$$
\operatorname{det} A=\sum(-1)^{\mathscr{P}} a_{1 i_{1}} a_{2 i_{2}} \cdots a_{n i_{n}}
$$

ahol az összegzést az $\{1, \ldots, n\}$ halmaz összes $\left\{i_{1}, \ldots, i_{n}\right\}$ permutációjára végezzük, tehát a szumma $n$ ! tagból áll. A $(-1)$ kitevője aszerint páros vagy páratlan, hogy az adott $\left\{i_{1}, \ldots, i_{n}\right\}$ permutáció páros vagy páratlan.

Szokásos még az alábbi jelölésmód is:

$$
\operatorname{det} A=|A|=\left|\begin{array}{rrrr}
a_{11} & a_{12} & \ldots & a_{1 n} \\
a_{21} & a_{22} & \ldots & a_{2 n} \\
\vdots & & & \\
a_{n 1} & a_{n 2} & \ldots & a_{n n}
\end{array}\right|
$$

Látható a definícióból, hogy a szumma mögötti szorzatokat úgy állítjuk össze, hogy a mátrix minden sorából és minden oszlopából pontosan egy tényezôt tartalmazzanak.

30.6 Példa. Ellenőrizzük közvetlenül a definíció alapján, hogy az

$$
A=\left[\begin{array}{rr}
2 & -1 \\
3 & 4
\end{array}\right] \quad \text { és } \quad B=\left[\begin{array}{rrr}
2 & 1 & -1 \\
0 & 1 & 3 \\
1 & 0 & -2
\end{array}\right]
$$

mátrixokra $\operatorname{det} A=11$ és $\operatorname{det} B=0$.

\subsection{A determináns tulajdonságai}

30.7 Állítás. $\operatorname{det} A=\operatorname{det} A^{T}$. 
Valóban, ha a mátrix oszlopait és sorait felcseréljük, akkor az inverziók paritása nem változik.

30.8 Állítás. Ha egy mátrix valamely sora csupa nullából áll, akkor a determinánsa zérus.

Valóban, ekkor a szumma mögött mindegyik tagban szerepel zérus tényező.

30.9 Állítás. Ha egy mátrix két sorát felcseréljük, akkor a determinánsa elójelet vált.

Valóban, ilyenkor mindegyik tagban az inverziók száma eggyel megváltozik.

30.10 Állítás. Ha egy mátrixban két sor azonos, akkor a determinánsa zérus.

Valóban, a két azonos sort felcserélve egyrészt a determináns előjelet vált, másrészt természetesen nem változik, azaz $\operatorname{det} A=-\operatorname{det} A$, és így $\operatorname{det} A=0$.

30.11 Állítás. Ha egy mátrix valamely sorát $\lambda$-val szorozzuk, akkor a determinánsa is $\lambda$-val szorzódik.

Valóban, ilyenkor a szumma mögött minden tag $\lambda$-val szorzódik, hiszen minden tag minden sorból pontosan egy tényezôt tartalmaz.

30.12 Állítás. Ha egy mátrixban valamelyik sor egy másik $\lambda$-szorosa, akkor a determinánsa zérus.

Valóban, ha a $\lambda$ szorzót az adott sorból kiemeljük, akkor olyan mátrixhoz jutunk, amelyben két azonos sor található.

30.13 Állítás. Ha egy mátrixban egy sor minden eleme összegként áll elô, például

$$
a_{i j}=b_{i j}+c_{i j} \quad j=1, \ldots, n
$$

akkor a determinánsa azon két determináns összege, amelyeknél az $i$-ik sor rendre a $b_{i j}$ illetve a $c_{i j}$ elemekból áll.

Valóban, a szumma mögött minden szorzat pontosan ilyen összegre bomlik.

30.14 Állítás. Ha egy mátrix valamely sora a többi sor lineáris kombinációja, akkor a determinánsa zérus. 
Valóban, bontsuk fel a determinánst összegre a megelező állítás értelmében. Ha most a skalár együtthatókat mindegyik determinánsból kiemelve olyan determinánsokhoz jutunk, amelyekben rendre két sor megegyezik, ezért mindegyik zérus.

30.15 Állítás. Ha egy mátrixban valamely sorhoz hozzáadjuk egy másik sor $\lambda$-szorosát, akkor a determinánsa nem változik.

Valóban, ekkor determináns két olyan determináns összegére bomlik, ahol a második tag zérus.

30.16 Állítás. Ha $A$ ás $B n \times n$-es mátrixok, akkor $\operatorname{det}(A B)=\operatorname{det} A \cdot \operatorname{det} B$.

Ez az állítás az előző állításaink felhasználásával, a mátrixszorzás lépésenkénti elvégzésével ellenőrizhető.

Végezetül állítasaink következményeként az alábbi fontos tételt fogalmazhatjuk meg.

30.17 Tétel. Az A négyzetes mátrix oszlopai akkor és csak akkor lineárisan összefüggók, ha $\operatorname{det} A=0$.

A szükségesség a 30.14 Állítás közvetlen következménye. Az elégségesség abból adódik, hogy ha $A$ oszlopai lineárisan függetlenek, akkor $A$ invertálható, és ezért $A A^{-1}=E$. Tehát

$$
\operatorname{det}\left(A A^{-1}\right)=\operatorname{det} A \cdot \operatorname{det} A^{-1}=\operatorname{det} E=1
$$

következésképpen $\operatorname{det} A \neq 0$.

\subsection{A determináns kiszámítása}

A definíció alapján világos, hogy egy $2 \times 2$-es mátrix determinánsa

$$
\operatorname{det} A=a_{11} a_{22}-a_{12} a_{21}
$$

Teljesen hasonlóan egy $3 \times 3$-as mátrix determinánsa a következő alakban írható

$$
\operatorname{det} A=a_{11}\left|\begin{array}{ll}
a_{22} & a_{23} \\
a_{32} & a_{33}
\end{array}\right|-a_{12}\left|\begin{array}{ll}
a_{21} & a_{23} \\
a_{31} & a_{33}
\end{array}\right|+a_{13}\left|\begin{array}{ll}
a_{21} & a_{22} \\
a_{31} & a_{32}
\end{array}\right|
$$

Ha ezt az észrevételt induktívan többször alkalmazzuk, akkor a következő eredményhez jutunk.

30.18 Tétel. Tekintsük az A $n \times n$-es mátrixot, és jelentse $A_{1 j}$ azt az $(n-1) \times(n-1)$-es mátrixot, amelyet az A elsó sorának és j-ik oszlopának elhagyásával nyerünk. Ekkor

$$
\operatorname{det} A=\sum_{j=1}^{n}(-1)^{j+1} a_{1 j} \operatorname{det} A_{1 j}
$$

Ezt az eljárást aldeterminánsokra történó felbontásnak nevezzük. 
30.19 Példa. Használjuk az aldeterminánsokra történő felbontási eljárást az

$$
A=\left[\begin{array}{llll}
3 & 6 & 0 & 2 \\
0 & 1 & 2 & 4 \\
4 & 8 & 3 & 5 \\
1 & 2 & 0 & 0
\end{array}\right]
$$

mátrixra. Ellenôrizzük lépésenként elôször $3 \times 3$-as, majd $2 \times 2$-es aldeterminánsokra való felbontással, hogy $\operatorname{det} A=-6$.

\subsection{Sajátértékek meghatározása}

Tegyük fel a továbbiakban, hogy $A$ egy $n \times n$-es mátrix, amelynek $\lambda$ sajátértéke, és $v \neq 0$ egy hozzá tartozó sajátvektor, azaz $A v=\lambda \nu$. Ezt úgy is írhatjuk, hogy

$$
A v-\lambda v=(A-\lambda E) v=0 .
$$

Ez az egyenlőség azt jelenti, hogy az $A-\lambda E$ mátrix oszlopai lineárisan összefüggők, hiszen a homogén lineáris egyenletrendszernek létezik nemtriviális megoldása. Tehát a 30.17Tétel értelmében a következő eredményt fogalmazhatjuk meg.

30.20 Tétel. A $\lambda$ szám akkor és csak akkor az A sajátértéke, ha $\operatorname{det}(A-\lambda E)=0$.

Ez a szükséges és elégséges feltétel egy $n$-edfokú egyenletet ad az $A$ sajátértékeire.

30.21 Példa. Tekintsük a következő mátrixot

$$
A=\left[\begin{array}{lll}
0 & 1 & 1 \\
1 & 0 & 1 \\
1 & 1 & 0
\end{array}\right]
$$

és keressük meg a sajátértékeit. Állítsuk elő az $A-\lambda E$ mátrix determinánsát:

$$
\operatorname{det}(A-\lambda E)=(\lambda+1)^{2}(\lambda-2)
$$

Ennek a harmadfokú polinomnak a gyökei $\lambda_{1}=-1$ (kétszeres gyök), illetve $\lambda_{2}=2$, amelyek az $A$ sajátértékei. Gyakorlásképpen keressük meg a megfelelő sajátvektorokat is. Ekkor az

$$
(A-\lambda E) v=0
$$

homogén lineáris egyenletrendszer lineáriasan független megoldásaira például $\lambda=-1$ mellett

$$
v_{1}=\left[\begin{array}{r}
-1 \\
1 \\
0
\end{array}\right] \quad \text { és } \quad v_{2}=\left[\begin{array}{r}
-1 \\
0 \\
1
\end{array}\right]
$$


illetve $\lambda=2$ mellett

$$
v_{3}=\left[\begin{array}{l}
1 \\
1 \\
1
\end{array}\right]
$$

vektorok adódnak. Tehát a $v_{1}, v_{2}, v_{3}$ bázisban az $A$ mátrix az

$$
\hat{A}=\left[\begin{array}{rrr}
-1 & 0 & 0 \\
0 & -1 & 0 \\
0 & 0 & 2
\end{array}\right]
$$

diagonális alakot ölti.

\section{Otthoni tanuláshoz}

1. A Feladatgyứjtemény-1 II/2 és II/6 szakaszai kidolgozott példáinak feldolgozása.

2. Házi feladatok: a II/2 szakasz 2.3.2, 2.3.3 és 2.3.6, továbbá a II/6 szakasz 6.4.1, 6.4.2, 6.4.3, 6.4.4, 6.4.5, 6.4.8, 6.4.9 és 6.4.10 feladatai.

3. Tankönyv-1 13.1, 13.2, 13.3, 13.4 és 13.5 szakaszai. 
31.

SKALÁRIS SZORZAT 



\subsection{Skaláris szorzat}

31.1 Definíció. Az $x$ és $y \mathbb{R}^{n}$-beli vektorok skaláris szorzatán az

$$
\langle x, y\rangle=x_{1} y_{1}+\ldots+x_{n} y_{n}
$$

kifejezést értjük, ahol a jobb oldalon a vektorok koordinátái szerepelnek.

Gondoljuk meg, hogy ez az értelmezés $n=2$ esetében pontosan megegyezik a középiskolában tanult fogalommal.

31.2 Definíció. Az $x \in \mathbb{R}^{n}$ vektor normáján (vagy abszolút értékén) a következőt értjük:

$$
\|x\|=(\langle x, x\rangle)^{1 / 2}=\sqrt{x_{1}^{2}+\ldots+x_{n}^{2}}
$$

amelyet a vektor hosszának is nevezünk.

Könnyen látható, hogy a Pitagorasz-tétel értelmében ez a megfogalmazásunk összhangban van az eddigi geometriai szemléletünkkel. Az is világos, hogy $\|x\|=0$ akkor és csak akkor áll, ha $x=0$.

31.3 Definíció. Az $x$ és $y$ vektorok távolságán az $\|x-y\|$ kifejezést értjük.

31.4 Példa. Például az

$$
x=\left[\begin{array}{r}
2 \\
-2 \\
1
\end{array}\right] \text { és } y=\left[\begin{array}{r}
4 \\
-3 \\
0
\end{array}\right]
$$

vektorokra $\langle x, y\rangle=14$, továbbá $\|x\|=3$, illetve $\|y\|=5$. A két vektor távolságára $\| x-$ $y \|=\sqrt{6}$ adódik.

\subsection{Vektorok szöge, merölegesség}

31.5 Tétel. Cauchy-Schwarz-egyenlötlenség Bármely $x, y \in \mathbb{R}^{n}$ vektorokra

$$
|\langle x, y\rangle| \leq\|x\| \cdot\|y\|
$$


Bizonyítás. Legyen $t$ tetszőleges valós szám, és tekintsük az alábbi másodfokú polinomot:

$$
g(t)=\langle x+t y, x+t y\rangle
$$

Először is a skaláris szorzat értelmezése alapján

$$
g(t)=\|x\|^{2}+2 t\langle x, y\rangle+t^{2}\|y\|^{2}
$$

másrészt ez a kifejezés az $x+t y$ vektor normája, tehát nem negatív, azaz

$$
g(t) \geq 0 \quad \text { minden } t \text { esetén. }
$$

Ha egy másodfokú polinom nem negatív, akkor a diszkriminánsa nem pozitív, azaz

$$
4(\langle x, y\rangle)^{2} \leq 4\|x\|^{2} \cdot\|y\|^{2}
$$

4-gyel egyszerúsítve, és mindkét oldalból négyzetgyököt vonva éppen azt kapjuk, hogy

$$
|\langle x, y\rangle| \leq\|x\| \cdot\|y\|
$$

amit igazolnunk kellett.

31.6 Tétel. (Háromszög-egyenlőtlenség) $\|x+y\| \leq\|x\|+\|y\|$.

Bizonyítás. Valóban, a Cauchy-Schwartz-egyenlőtlenség folytán

$$
\begin{aligned}
\|x+y\|^{2} & =\langle x+y, x+y\rangle=\|x\|^{2}+2\langle x, y\rangle+\|y\|^{2} \\
& \leq\|x\|^{2}+2\|x\| \cdot\|y\|+\|y\|^{2}=(\|x\|+\|y\|)^{2}
\end{aligned}
$$

ahonnan négyzetgyökvonással adódik a tétel állítása.

31.7 Definíció. Az $x$ és $y$ nem nulla vektorok által bezárt szögön azt a $0 \leq \varphi \leq \pi$ szöget értjük, amelyre

$$
\cos \varphi=\frac{\langle x, y\rangle}{\|x\| \cdot\|y\|}
$$

Azt mondjuk továbbá, hogy $x$ és $y$ egymásra ortogonálisak (vagy merőlegesek), jelölésben $x \perp y$, ha

$$
\langle x, y\rangle=0
$$

hiszen ilyenkor $\cos \varphi=0$, azaz $\varphi=\pi / 2$. A 0 vektor minden más vektorra meróleges.

FIGYELEM! Gondoljuk meg, hogy a vektorok szögét jól definiáltuk, ugyanis a Cauchy-Schwartz-féle egyenlőtlenség értelmében $-1 \leq \cos \varphi \leq 1$. 


\subsection{Ortogonális vektorok}

31.8 Definíció. Azt mondjuk, hogy az $\mathbb{R}^{n}$ térben az $a_{1}, \ldots, a_{k}$ vektorok ortogonális rendszert alkotnak, ha egyikük sem nulla vektor, és a vektorok páronként merôlegesek, azaz

$$
\left\langle a_{i}, a_{j}\right\rangle=0
$$

bármely $i \neq j$ indexekre.

31.9 Tétel. Minden ortogonális rendszer lineárisan független.

Bizonyítás. Tekintsük az $a_{1}, \ldots, a_{k}$ ortogonális rendszert, és tegyük fel, hogy

$$
\alpha_{1} a_{1}+\ldots+\alpha_{k} a_{k}=0 .
$$

Szorozzuk meg skalárisan mindkét oldalt az $a_{i}$ vektorral. Ekkor a páronkénti ortogonalitás miatt az $i$-ik tag kivételével mindegyik szorzat nulla, azaz

$$
\alpha_{i}\left\|a_{i}\right\|^{2}=0
$$

adódik. Mivel $a_{i} \neq 0$, innen azt kapjuk, hogy $\alpha_{i}=0$. Ezt a gondolatot mindegyik $i=$ $1, \ldots, k$ indexre alkalmazhatjuk, ezért $\alpha_{1}=\ldots=\alpha_{k}=0$. Ez éppen azt jelenti, hogy az $a_{1}, \ldots, a_{k}$ vektorok lineárisan függetlenek.

Ez a tételünk azt mutatja, hogy az $\mathbb{R}^{n}$ térben maximum $n$-elemú ortogonális rendszer található. Egyúttal egy $n$-elemú ortogonális rendszer a tér bázisát alkotja.

31.10 Definíció. Az $\mathbb{R}^{n}$ tér egy ortogonális bázisán egy $a_{1}, \ldots, a_{n}$ ortogonális rendszert értünk. Azt mondjuk, hogy ez a bázis ortonormált, ha a bázisvektorok egységnyi normájúak, azaz $\left\|a_{i}\right\|=1$ minden $i=1, \ldots, n$ esetén.

Analóg módon értelmezzük egy tetszőleges $M$ altér ortonormált bázisát is.

31.11 Példa. Könnyen ellenőrizhetô például, hogy az

$$
a_{1}=\left[\begin{array}{r}
\frac{\sqrt{3}}{2} \\
0 \\
-\frac{1}{2}
\end{array}\right], \quad a_{2}=\left[\begin{array}{r}
\frac{1}{2} \\
0 \\
\frac{\sqrt{3}}{2}
\end{array}\right], \quad a_{3}=\left[\begin{array}{r}
0 \\
-1 \\
0
\end{array}\right]
$$

vektorok az $\mathbb{R}^{3}$ tér ortonormált bázisát szolgáltatják. 


\subsection{Gram-Schmidt-féle eljárás}

Ortonormált bázisban felírt vektorokkal nagyon könnyű számolni, ezért természetes kérdésként merül fel, hogy vajon minden altérben létezik-e ortonormált bázis. Erre ad pozitív választ a Gram-Schmidt-módszer, amelynek segítségével elő is tudjuk állítani ezt a bázist.

Tekintsük az $\mathbb{R}^{n}$ tér egy tetszóleges $M$ alterét, amelynek $a_{1}, \ldots, a_{k}$ bázisa. Megmutatjuk, hogy ebből kiindulva megszerkeszthetünk egy ortonormált bázist.

Legyen $b_{1}=a_{1}$. Ezután legyen $b_{2}=a_{2}+\alpha_{1} b_{1}$, ahol az ismeretlen $\alpha_{1}$ együtthatót úgy választjuk meg, hogy $b_{2}$ merôleges legyen a $b_{1}$ vektorra. Tehát

$$
\left\langle b_{2}, b_{1}\right\rangle=\left\langle a_{2}, b_{1}\right\rangle+\alpha_{1}\left\langle b_{1}, b_{1}\right\rangle=0
$$

Ebből az egyenlőségből azt kapjuk, hogy

$$
\alpha_{1}=-\frac{\left\langle b_{1}, a_{2}\right\rangle}{\left\|b_{1}\right\|^{2}}
$$

ahonnan

$$
b_{2}=a_{2}-\frac{\left\langle b_{1}, a_{2}\right\rangle}{\left\|b_{1}\right\|^{2}} b_{1} .
$$

Teljesen hasonló gondolatmenet alapján a $b_{3}$ vektort a

$$
b_{3}=a_{3}+\beta_{1} b_{1}+\beta_{2} b_{2}
$$

alakban keressük úgy, hogy $b_{3}$ ortogonális legyen a $b_{1}$ és $b_{2}$ vektorok mindegyikére. Ekkor a két feltételből az együtthatókat meghatározva

$$
b_{3}=a_{3}-\frac{\left\langle b_{1}, a_{3}\right\rangle}{\left\|b_{1}\right\|^{2}} b_{1}-\frac{\left\langle b_{2}, a_{3}\right\rangle}{\left\|b_{2}\right\|^{2}} b_{2} .
$$

adódik. Az eljárást folytatva az $M$ altér egy ortogonális bázisához jutunk. Ezt az eredményt a következő tételben fogalmazzuk meg.

31.12 Tétel. (Gram-Schmidt) Az $\mathbb{R}^{n}$ tér bármely alterében van ortonormált bázis.

Bizonyítás. A fenti eljárásban mindegyik $b_{i}$ bázisvektort osszuk el a $\left\|b_{i}\right\|$ pozitív számmal, akkor egy ortonormált bázishoz jutunk.

\subsection{Az ortogonális komplementer}

Tekintsünk egy tetszőleges $M$ alteret az $\mathbb{R}^{n}$ vektortérben.

31.13 Definíció. Az $M$ altér összes vektorára merőleges vektorok halmazát, jelölésben

$$
M^{\perp}=\left\{y \in \mathbb{R}^{n}:\langle y, x\rangle=0 \text { minden } x \in M \text { esetén }\right\}
$$

az $M$ ortogonális komplementerének nevezzük. 
Könnyen ellenôrizhető, hogy $M^{\perp}$ is altér az $\mathbb{R}^{n}$ térben.

31.14 Példa. A három dimenziós térben egy origón átmenő egyenes merôleges kiegészítője az origón átmenô, az egyenesre merôleges sík. Fordítva, a sík merôleges kiegészítője a rá merőleges egyenes.

Ha például az $M$ altér két adott vektor által generált altér, például

$$
M=\operatorname{lin}\left\{\left[\begin{array}{r}
-1 \\
0 \\
1
\end{array}\right],\left[\begin{array}{l}
1 \\
2 \\
1
\end{array}\right]\right\}
$$

akkor a merőleges kiegészítője az alábbi egyetlen vektor által generált altér:

$$
M^{\perp}=\operatorname{lin}\left\{\left[\begin{array}{r}
1 \\
-1 \\
1
\end{array}\right]\right\}
$$

Ez fordítva is igaz, ezt fogalmazza meg a következô tétel.

31.15 Tétel. Bármely $M$ altérre $\left(M^{\perp}\right)^{\perp}=M$.

Az állítást könnyen ellenőrizhetjük közvetlenül a definíció alapján.

31.16 Tétel. Legyen $a \in \mathbb{R}^{n}$ és $M$ egy tetszóleges altér. Akkor van pontosan egy olyan $u \in M$ vektor, amelyre

$$
a-u \in M^{\perp}
$$

Bizonyítás. Válasszunk egy $b_{1}, \ldots, b_{k}$ ortonormált bázist az $M$ altérben. Keressük az $u$ vektort az $M$ altérben az

$$
u=\alpha_{1} b_{1}+\ldots+\alpha_{k} b_{k}
$$

alakban. Az ismeretlen együtthatókat úgy kell megválasztanunk, hogy $a-u$ mindegyik bázisvektorra ortogonális legyen. Ez azt jelenti, hogy

$$
\left\langle b_{i}, a-u\right\rangle=\left\langle b_{i}, a\right\rangle-\alpha_{i}=0
$$

minden $i=1, \ldots, k$ indexre, amivel az ismeretlen együtthatókat meghatároztuk.

Ezt az $u$ vektort az $a$ ortogonális vetületének nevezzük az $M$ altérre.

31.17 Tétel. Legyen $M a z \mathbb{R}^{n}$ egy tetszóleges altere. Akkor bármely a $\in \mathbb{R}^{n}$ vektor egyértelmüen írható fel

$$
a=u+v
$$

alakban, ahol $u \in M$ és $v \in M^{\perp}$. 
Bizonyítás. Jelentse $u \in M$ az $a$ ortogonális vetületét az $M$ altérre. Ekkor a $v=a-u$ ortogonális az $M$ altérre, ezért $v \in M^{\perp}$.

Az egyértelmúség abból következik, hogy ha

$$
a=u^{\prime}+v^{\prime}
$$

is ilyen előállítás lenne, akkor a két egyenletet kivonva $u-u^{\prime}=v-v^{\prime}$ adódna. Ez azt jelentené, hogy $u-u^{\prime} \in M$ és $u-u^{\prime} \in M^{\perp}$. Tehát $u-u^{\prime}$ merőleges lenne saját magára is, azaz

$$
0=\left\langle u-u^{\prime}, u-u^{\prime}\right\rangle=\left\|u-u^{\prime}\right\|^{2}
$$

és ez csak úgy lehetséges, ha $u-u^{\prime}=0$ és ugyanígy $v-v^{\prime}=0$.

31.18 Tétel. Legyen $M$ az $\mathbb{R}^{n}$ tér egy tetszóleges altere. Akkor

$$
\operatorname{dim} M+\operatorname{dim} M^{\perp}=n .
$$

Bizonyítás. Tekintsük az $M$ valamely $u_{1}, \ldots, u_{k}$ ortonormált bázisát, illetve az $M^{\perp}$ valamely $v_{1}, \ldots, v_{m}$ ortonormált bázisát. Ekkor az előző tételünk szerint az

$$
u_{1}, \ldots, u_{k}, v_{1}, \ldots, v_{m}
$$

vektorrendszer a tér minden vektorát előállítja, tehát generátorrendszer, ezért $k+m \geq n$. Másrészt a vektorrendszer elemei páronként ortogonálisak, ezért lineárisan függetlenek, ezért $k+m \leq n$. Következésképpen $k+m=n$.

\section{Otthoni tanuláshoz}

1. A Feladatgyưjitemény-1 II/1 szakasza kidolgozott példáinak feldolgozása.

2. Házi feladatok: a II/1 szakasz 1.3.2, 1.3.4, 1.4.3, 1.4.4, 1.5.3, 1.5.4, 1.6.3, 1.7.3, $1.8 .4,1.9 .2,1.9 .8,1.10 .2$ és 1.10 .3 feladatai.

3. Tankönyv-1 12.4 és 12.5 szakaszai. 


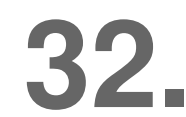

A SPEKTRÁLTÉTEL 



\subsection{Transzponált mátrix}

Tekintsük az $\mathbb{R}^{n}$ tér egy $A$ lineáris transzformációját, azaz $n \times n$-es mátrixot.

32.1 Definíció. Az A transzponáltján azt az $A^{T}$ transzformációt értjük, amelyre

$$
\left\langle A^{T} y, x\right\rangle=\langle y, A x\rangle
$$

minden $x, y \in \mathbb{R}^{n}$ esetén.

Vajon milyen alakú az $A^{T}$ mátrix? Irjuk fel a definíciót speciálisan a bázisvektorokra, akkor

$$
\left\langle A^{T} e_{i}, e_{j}\right\rangle=\left\langle e_{i}, A e_{j}\right\rangle
$$

bármely $i$ és $j$ indexekre. Az egyenlôség jobb oldalán $a_{i j}$ azaz $A i$-ik sorának $j$-ik eleme áll, a bal oldalon $A^{T} j$-ik sorának $i$-ik eleme. Tehát az $A^{T}$ mátrixot az $A$ sorainak és oszlopainak felcserélésével kapjuk.

Úgy is fogalmazhatjuk, hogy az $A^{T}$ mátrix az $A$ elemeinek a fődiagonálisra tükrözésével nyerhető. Nyilvánvalóan $\left(A^{T}\right)^{T}=A$.

32.2 Tétel. Bármely $A n \times n$-es mátrixra

$$
\operatorname{ker} A=\left(\operatorname{im} A^{T}\right)^{\perp}
$$

Bizonyítás. Egyrészt, ha az $x$ vektor ortogonális az im $A^{T}$ altérre, akkor

$$
0=\left\langle A^{T} y, x\right\rangle=\langle y, A x\rangle
$$

minden $y$ vektor esetén. Ez csak úgy lehetséges, ha $A x=0$, azaz $x \in \operatorname{ker} A$.

Fordítva, a fenti egyenlőség miatt $\operatorname{ker} A$ minden eleme ortogonális az $\operatorname{im} A^{T}$ altérre.

Ebből az észrevételből könnyen következik a mátrixok rangtétele.

32.3 Tétel. (Mátrixok rangtétele) Bármely $A n \times n$-es mátrixra

$$
\operatorname{rank} A=\operatorname{rank} A^{T}
$$

Bizonyítás. Valóban, az előző tételünk és a 31.18 Tétel szerint

$$
\operatorname{dim} \operatorname{ker} A+\operatorname{dimim} A^{T}=n
$$

és innen a 27.7 Tétel alapján $\operatorname{dimim} A=\operatorname{dimim} A^{T}$, ami az állításunkat igazolja.

Ezt a tételünket úgy is megfogalmazhatjuk, hogy egy négyzetes mátrixban a lineárisan független oszlopok száma megegyezik a lineárisan független sorok számával. 


\subsection{Ortogonális mátrixok}

32.4 Definíció. Az $\mathbb{R}^{n}$ tér egy $S$ transzformációját ortogonálisnak nevezzük, ha invertálható, és $S^{-1}=S^{T}$.

Vajon milyen alakú $S$ mátrixa? Az $S^{T} S=E$ egyenlőség azt jelenti, hogy az $S i$-ik oszlopának önmagával vett skaláris szorzata 1 , továbbá $i \neq j$ esetén az $i$-ik és a $j$ ik oszlopok skaláris szorzata nulla. Tehát mindegyik oszlop egységnyi normájú, és a különböző oszlopok páronként ortogonálisok. Innen ered az elnevezés is.

32.5 Példa. Jelentse például $S$ a sík vektorainak origó körüli elforgatását $\varphi$ szöggel pozitív irányba. Amint már láttuk, ennek a transzformációnak a mátrixa

$$
S=\left[\begin{array}{rr}
\cos \varphi & -\sin \varphi \\
\sin \varphi & \cos \varphi
\end{array}\right]
$$

amelyrôl könnyen látható, hogy ortogonális, hiszen az oszlopok egységnyi normájúak, és a két oszlop skaláris szorzata nulla. Tehát

$$
S^{-1}=\left[\begin{array}{rr}
\cos \varphi & \sin \varphi \\
-\sin \varphi & \cos \varphi
\end{array}\right]
$$

ami éppen a $-\varphi$ szöggel történő elforgatás mátrixa. Ellenőrizzük ezt közvetlenül az $S^{T} S$ szorzatmátrix kiszámolásával is.

32.6 Tétel. Egy ortogonális transzformáció megtartja a vektorok hosszát.

Bizonyítás. Valóban, ha $S$ ortogonális transzformáció, akkor

$$
\|S x\|^{2}=\langle S x, S x\rangle=\left\langle S^{T} S x, x\right\rangle=\langle x, x\rangle=\|x\|^{2}
$$

minden $x$ vektor esetén.

32.7 Tétel. Egy ortogonális transzformáció minden sajátértéke egységnyi abszolút értékú.

Bizonyítás. Ha $\lambda$ az $S$ ortogonális transzformáció sajátértéke, és $v \neq 0$ egy hozzá tartozó sajátvektor, akkor

$$
\lambda^{2}\|v\|^{2}=\langle\lambda v, \lambda v\rangle=\langle S v, S v\rangle=\left\langle S^{T} S v, v\right\rangle=\|v\|^{2}
$$

ahonnan adódik, hogy $\lambda^{2}=1$. 


\subsection{Szimmetrikus mátrixok}

32.8 Definíció. Az $\mathbb{R}^{n}$ tér egy $A$ transzformációját szimmetrikusnak nevezzük, ha $A=$ $A^{T}$.

Világos, hogy az A mátrixa ilyenkor szimmetrikus (innen a név) a fődiagonálisra, azaz $a_{i j}=a_{j i}$ minden $i$ és $j$ indexre. A 32.2 Tétel speciális eseteként adódik az alábbi állítás.

32.9 Tétel. Ha A szimmetrikus mátrix, akkor

$$
\operatorname{ker} A=(\operatorname{im} A)^{\perp}
$$

Mit mondhatunk egy $A n \times n$-es szimmetrikus transzformáció sajátértékeiről és sajátvektorairól? Jelentse

$$
P(\lambda)=\operatorname{det}(A-\lambda E)
$$

az $A$ (n-edfokú) karakterisztikus polinomját.

32.10 Tétel. A P polinomnak van valós gyöke. Ezért az A szimmetrikus transzformációnak létezik valós sajátértéke, és hozzá tartozó nem nulla sajátvektora.

A tétel bizonyítása elég komplikált számolást igényel, ezért azt elhagyjuk. Megjegyezzük, hogy az is igazolható, hogy a $P$ polinomnak multiplicitással számolva pontosan $n$ valós gyöke van.

32.11 Tétel. Ha A szimmetrikus transzformáció, akkor az, $\mathbb{R}^{n}$ térnek létezik az A sajátvektoraiból álló ortonormált bázisa.

Bizonyítás. A bizonyítást teljes indukcióval végezzük az $1 \leq k \leq n$ értékekre. Az előző tétel alapján, ha $k=1$, akkor az $A$ transzformációnak van egy $\lambda_{1}$ valós sajátértéke, és egy hozzá tartozó $v_{1}$ sajátvektor, amelyre $\left\|v_{1}\right\|=1$.

Tegyük fel, hogy már találtunk $v_{1}, \ldots, v_{k-1}$ ortonormált sajátvektort, és jelölje $M$ az általuk generált alteret. Ekkor $A$ az $M^{\perp}$ alteret önmagába képezi (invariáns), ha ugyanis $x \in M^{\perp}$ tetszőleges vektor, akkor

$$
\left\langle v_{i}, A x\right\rangle=\left\langle A v_{i}, x\right\rangle=\left\langle\lambda v_{i}, x\right\rangle=0
$$

minden $i=1, \ldots, k-1$ esetén, tehát $A x \in M^{\perp}$. Ha most az $A$ szimmetrikus transzformációt az $M^{\perp}$ altérre leszúkítve tekintjük, akkor az előző tételünk szerint itt is van legalább egy valós $\lambda_{k}$ sajátértéke, és hozzá tartozó $v_{k}$ sajátvektora, amelyre $\left\|v_{k}\right\|=1$.

A konstrukció folytán ez a $v_{k}$ sajátvektor ortogonális a $v_{1}, \ldots, v_{k-1}$ sajátvektorokra, ezért $v_{1}, \ldots, v_{k}$ ortonormált rendszert alkotnak. 


\subsection{Szimmetrikus mátrixok spektráltétele}

Ebben a szakaszban azt mutatjuk meg, hogy hogyan végezhető el egy szimmetrikus mátrix diagonális alakra transzformálása.

Legyen tehát $A$ egy adott $n \times n$-es szimmetrikus mátrix. A 32.11 Tétel értelmében található az $\mathbb{R}^{n}$ térnek olyan ortonormált bázisa, amely az $A$ sajátvektoraiból áll. Jelentse $S$ azt a mátrixot, amelynek oszlopai rendre ezek a sajátvektorok.

Világos, hogy $S$ ekkor ortogonális mátrix, tehát $S^{-1}=S^{T}$. A 29.10 Tételt így speciálisan szimmetrikus mátrixokra a következő módon fogalmazhatjuk át.

32.12 Tétel. (Szimmetrikus mátrixok spektráltétele) Legyen A $n \times n$-es szimmetrikus mátrix, és tekintsük a tér egy sajátvektorokból álló ortonormált bázisát. Jelentse $S$ a sajátvektorokból alkotott mátrixot. Ekkor $S$ ortogonális, továbbá A mátrixa a sajátvektorok bázisában

$$
\hat{A}=S^{T} A T
$$

alakú, ahol Â a következố alakú diagonális mátrix:

$$
\hat{A}=\left[\begin{array}{ccc}
\lambda_{1} & \ldots & 0 \\
& \ddots & \\
0 & \ldots & \lambda_{n}
\end{array}\right]
$$

ahol a fódiagonálisban rendre a megfeleló sajátértékek állnak.

Nézzük meg, hogy egy adott $A$ szimmetrikus mátrix esetén hogyan állítható elő az $S$ mátrix.

Az egyszerú eset az, amikor az $A$ mátrixnak $n$ számú különböző sajátértéke van. Ilyenkor a megfelelő sajátvektorok automatikusan ortogonálisok egymásra. Ezért az $S$ mátrixot úgy nyerjük, hogy az egymás utáni oszlopokba írjuk az egységnyi normájú sajátvektorokat.

32.13 Példa. Tekintsük a következő szimmetrikus $A$ mátrixot

$$
A=\left[\begin{array}{rrr}
2 & 0 & 2 \\
0 & -2 & 0 \\
2 & 0 & 5
\end{array}\right]
$$

Határozzuk meg a sajátértékeket! Az A karakterisztikus polinomja

$$
P(\lambda)=\left(\lambda^{2}-7 \lambda+6\right)(-2-\lambda)
$$

amelynek gyökei $\lambda_{1}=1, \lambda_{2}=-2$ és $\lambda_{3}=6$. A megfelelő sajátvektorokat különböző $\lambda$ sajátértékekre megkapjuk az $(A-\lambda E) x=0$ homogén rendszer megoldásaiként. Ezek 
pl. rendre

$$
v_{1}=\left[\begin{array}{r}
2 \\
0 \\
-1
\end{array}\right] \quad v_{2}=\left[\begin{array}{l}
0 \\
1 \\
0
\end{array}\right] \quad v_{3}=\left[\begin{array}{l}
1 \\
0 \\
2
\end{array}\right]
$$

Ezek a sajátvektorok egymásra ortogonálisok, amelyeket normálni kell, így az $S$ ortogonális mátrix:

$$
S=\left[\begin{array}{rrr}
\frac{2}{\sqrt{5}} & 0 & \frac{1}{\sqrt{5}} \\
0 & 1 & 0 \\
-\frac{1}{\sqrt{5}} & 0 & \frac{2}{\sqrt{5}}
\end{array}\right] \quad \text { és } \quad \hat{A}=\left[\begin{array}{rrr}
1 & 0 & 0 \\
0 & -2 & 0 \\
0 & 0 & 6
\end{array}\right]
$$

Ekkor

$$
\hat{A}=S^{T} A S
$$

amelyet ellenőrizünk közvetlenül a kijelölt szorzások elvégzésével is.

Kicsit bonyolultabb a helyzet akkor, ha egy sajátértékhez több lineárisan független sajátérték is tartozik. Ilyenkor szükség lehet a Gram-Schmidt-féle eljárásra ahhoz, hogy ezek a sajátvektorok is ortogonálisok legyenek egymásra. Ezt az esetet mutatjuk be egy példán keresztuil.

32.14 Példa. Módosítsuk az előzô példát a következő módon:

$$
A=\left[\begin{array}{lll}
2 & 0 & 2 \\
0 & 6 & 0 \\
2 & 0 & 5
\end{array}\right]
$$

ekkor a karakterisztikus polinom a következő alakot ölti

$$
P(\lambda)=(6-\lambda)\left(\lambda^{2}-7 \lambda+6\right)
$$

amelynek gyökei $\lambda_{1}=1$ és $\lambda_{2}=6$, ez utóbbi kétszeres gyök. A $\lambda_{1}$ sajátértékhez alkalmas sajátvektor az előző példa $v_{1}$ sajátvektora. A $\lambda_{2}=6$ sajátérték esetén az $(A-6 E) x=0$ homogén rendszer szabadságfoka 2, ezért két lineárisan független megoldás van, például

$$
v_{2}=\left[\begin{array}{l}
1 \\
0 \\
2
\end{array}\right] \quad \text { és } \quad v_{3}=\left[\begin{array}{l}
1 \\
1 \\
2
\end{array}\right]
$$

Ez a két vektor azonban nem ortogonális, ezért alkalmazzuk a Gram-Schmidt-féle eljárást. Ekkor $v_{3}$ helyett az alábbi $u_{3}$ sajátvektor adódik:

$$
u_{3}=v_{3}-\frac{\left\langle v_{3}, v_{2}\right\rangle}{\left\|v_{2}\right\|^{2}} v_{2}=\left[\begin{array}{l}
0 \\
1 \\
0
\end{array}\right]
$$


Tehát ekkor a következő mátrixokhoz jutunk

$$
S=\left[\begin{array}{ccc}
\frac{2}{\sqrt{5}} & \frac{1}{\sqrt{5}} & 0 \\
0 & & 1 \\
-\frac{1}{\sqrt{5}} & \frac{2}{\sqrt{5}} & 0
\end{array}\right] \text { és } \hat{A}=\left[\begin{array}{lll}
1 & 0 & 0 \\
0 & 6 & 0 \\
0 & 0 & 6
\end{array}\right]
$$

és ekkor

$$
\hat{A}=S^{T} A S
$$

amelyet újra ellenőrizzünk közvetlenül a kijelölt mátrixok összeszorzásának elvégzésével is.

1. A Feladatgyújtemény-1 II/6 szakasza kidolgozott példáinak feldolgozása.

2. Házi feladatok: a II/6 szakasz 6.2.4, 6.3.2, 6.3.3, 6.3.4, 6.4.2, 6.4.3, 6.4.6, 6.4.7, és 6.4.10 feladatai.

3. Tankönyv-1 14.5 és 14.6 szakaszok. 
33.

KVADRATIKUS ALAKOK 



\subsection{Kvadratikus alakok}

$\mathrm{Az} \mathbb{R}^{n}$ téren értelemezett tisztán másodfokú függvényt, azaz kvadratikus alakot, az alábbi módon értelmezzük.

33.1 Definíció. A $Q: \mathbb{R}^{n} \rightarrow \mathbb{R}$ függvényt kvadratikus alaknak nevezzük, ha

$$
Q(x)=Q\left(x_{1}, \ldots, x_{n}\right)=a_{11} x_{1}^{2}+a_{12} x_{1} x_{2}+a_{22} x_{2}^{2}+a_{13} x_{1} x_{3}+\ldots+a_{n n} x_{n}^{2}
$$

alakú, azaz olyan hatványfüggvény, amelyben minden tag tisztán másodfokú.

Egy kvadratikus alakhoz mindig megadhatunk egy $A n \times n$-es mátrixot úgy, hogy $Q$ a

$$
Q(x)=\langle x, A x\rangle
$$

skaláris szorzat alakjában írható fel, amint azt a következő példa mutatja.

33.2 Példa. Tekintsük az $\mathbb{R}^{3}$ téren értelmezett

$$
Q(x)=Q\left(x_{1}, x_{2}, x_{3}\right)=3 x_{1}^{2}-4 x_{1} x_{2}+2 x_{1} x_{3}+x_{2}^{2}+6 x_{2} x_{3}-5 x_{3}^{2}
$$

kvadratikus alakot. Az együtthatókból állítsuk össze az

$$
A=\left[\begin{array}{rrr}
3 & -4 & 2 \\
0 & 1 & 6 \\
0 & 0 & -5
\end{array}\right]
$$

mátrixot. Ellenőrizzük, hogy erre az $A$ mátrixra valóban $Q(x)=\langle x, A x\rangle$. Ez azonban nem az egyetlen ilyen tulajdonságú mátrix. Ha ugyanis a

$$
B=\left[\begin{array}{rrr}
3 & -2 & 1 \\
-2 & 1 & 3 \\
1 & 3 & -5
\end{array}\right]
$$

mátrixot tekintjük, akkor erre is teljesül, hogy $Q(x)=\langle x, B x\rangle$ minden $x \in \mathbb{R}^{3}$ mellett.

Ezen észrevétel alapján azt mondhatjuk, hogy végtelen sok olyan $A$ mátrix található, amelyre fennáll a 33.1 azonosság, de csak egyetlen olyan $B$ mátrix, amelynek elemei a főátlóra nézve szimmetrikusak. 


\subsection{Kvadratikus alak mátrixa}

33.3 Definíció. Az $n \times n$-es $B$ mátrixot szimmetrikusnak nevezzük, ha az elemei a fóátlóra nézve szimmetrikusak, azaz

$$
b_{i j}=b_{j i}
$$

bármely $i, j=1, \ldots, n$ indexekre.

Szimmetrikus mátrixokra megfogalmazhatjuk az előző szakasz észrevételét kvadratikus alakokra.

33.4 Tétel. Tekintsünk egy $Q: \mathbb{R}^{n} \rightarrow \mathbb{R}$ kvadratikus alakot. Akkor található pontosan egy $B n \times n$-es szimmetrikus mátrix, amelyre

$$
Q(x)=\langle x, B x\rangle
$$

minden $x \in \mathbb{R}^{n}$ esetén. Fordítva, bármely B szimmetrikus mátrix a fenti skalárszorzattal egy kvadratikus alakot definiál.

Ez a tételünk azt fogalmazza meg, hogy a kavadratikus alakok és a szimmetrikus mátrixok között kölcsönösen egyértelmú megfeleltetés van.

33.5 Példa. Tekintsük például a

$$
Q\left(x_{1}, x_{2}, x_{3}\right)=2 x_{1}^{2}-2 x_{1} x_{2}+4 x_{1} x_{3}-x_{2}^{2}+8 x_{2} x_{3}+3 x_{3}^{2}
$$

kvadratikus alakot, és állítsuk elő a neki megfelelő $B$ szimmetrikus mátrixot.

Ekkor az előző szakasz példájához hasonlóan a vegyes szorzatok együtthatóit megfelezzük, és a következő szimmetrikus mátrixhoz jutunk:

$$
B=\left[\begin{array}{rrr}
2 & -1 & 2 \\
-1 & -1 & 4 \\
2 & 4 & 3
\end{array}\right]
$$

Ellenőrizzük, hogy ekkor valóban $Q(x)=\langle x, B x\rangle$ minden $x \in \mathbb{R}^{3}$ esetén. 


\subsection{Kvadratikus alakok definitsége}

A többváltozós szélsőérték megkereséséhez szükségünk lesz arra, hogy kvadratikus alakok milyen előjelú értékeket vesznek fel. Ehhez vezetjük be a következő definíciót.

33.6 Definíció. Azt mondjuk, hogy a $Q$ kvadratikus alak

- pozitív definit, ha $Q(x)>0$ minden $x \in \mathbb{R}^{n}, x \neq 0$ esetén,

- pozitív szemidefinit, ha $Q(x) \geq 0$ minden $x \in \mathbb{R}^{n}$ esetén, és van olyan $x_{0} \neq 0$, hogy $Q\left(x_{0}\right)=0$,

- negatív definit, ha $Q(x)<0$ minden $x \in \mathbb{R}^{n}, x \neq 0$ esetén,

- negatív szemidefinit, ha $Q(x) \leq 0$ minden $x \in \mathbb{R}^{n}$ esetén, és van olyan $x_{0} \neq 0$, hogy $Q\left(x_{0}\right)=0$,

- indefinit, ha a fentiek egyike sem teljesül.

33.7 Példa. Például a háromváltozós

$$
Q\left(x_{1}, x_{2}, x_{3}\right)=2 x_{1}^{2}-2 x_{1} x_{2}+x_{2}^{2}+3 x_{3}^{2}
$$

kvadratikus alak pozitív definit, hiszen a következőképpen alakítható át teljes négyzetek összegévé:

$$
Q\left(x_{1}, x_{2}, x_{3}\right)=x_{1}^{2}+\left(x_{1}-x_{2}\right)^{2}+3 x_{3}^{2},
$$

és ez a kifejezés minden $x \neq 0$ vektor esetén pozitív.

Ugyanakkor a

$$
Q\left(x_{1}, x_{2}, x_{3}\right)=x_{1}^{2}-2 x_{1} x_{2}+x_{2}^{2}+3 x_{3}^{2}=\left(x_{1}-x_{2}\right)^{2}+3 x_{3}^{2}
$$

kvadratikus alak csak pozitív szemidefinit, hiszen egyrészt $Q(x) \geq 0$ minden $x$ vektor mellett, másrészt például $Q(1,1,0)=0$, azaz található olyan nem nulla vektor, amelyen $Q$ nulla értéket vesz fel.

Teljesen hasonlóan a

$$
Q\left(x_{1}, x_{2}, x_{3}\right)=2 x_{1}^{2}-2 x_{1} x_{2}+x_{2}^{2}-3 x_{3}^{2}
$$

kvadratikus alak indefinit, hiszen egyaránt felvesz pozitív és negatív értékeket is. Behelyettesítéssel ellenőrizhető, hogy például $Q(1,1,0)=1>0$, és $Q(0,0,1)=-3<0$.

A továbbiakban a definitség fogalmait ugyanilyen módon fogjuk használni a $Q$ kvadratikus alaknak megfelelő $B$ szimmetrikus mátrixra is. 


\subsection{Teljes négyzetté alakítás}

Egy kvadratikus alak definitsége nagyon egyszerúen eldönthető, ha csak tiszta négyzetes tagokból áll (azaz nincs vegyesszorzat).

33.8 Példa. Tekintsük például az $\mathbb{R}^{4}$ téren a

$$
Q(x)=5 x_{1}^{2}+3 x_{2}^{2}+9 x_{3}^{2}+2 x_{4}^{2}
$$

kvadratikus alakot. Ez nyilván pozitív definit, hiszen a négyzetösszeg pozitív, ha $x \neq 0$.

$\mathrm{Az}$ is könnyen látható, hogy a

$$
R(x)=3 x_{1}^{2}+5 x_{2}^{2}-2 x_{4}^{2}
$$

kvadratikus alak viszont indefinit, hiszen például az

$$
x_{1}=1 \quad x_{2}=1 \quad x_{3}=0 \quad x_{4}=0
$$

vektoron felvett értéke pozitív, ugyanakkor az

$$
x_{1}=0 \quad x_{2}=0 \quad x_{3}=0 \quad x_{4}=1
$$

választással $R$ negatív értéket vesz fel.

Teljesen hasonló módon ellenőrizhetjük, hogy például a

$$
P(x)=3 x_{2}^{2}+x_{3}^{2}+x_{4}^{2}
$$

kvadratikus alak (FIGYELEM, $x_{1}$ hiányzik!) pozitív szemidefinit. Egyrészt ugyanis a négyzetösszeg nemnegatív, másrészt található olyan $x \neq 0$ vektor, nevezetesen

$$
x_{1}=1 \quad \text { és } \quad x_{2}=x_{3}=x_{4}=0
$$

amelyre $P$ értéke nulla. Ezért $P$ nem lehet pozitív definit.

A fenti példa észrevételeit a következő tételben fogalmazhatjuk meg.

33.9 Tétel. Tegyük fel, hogy $Q$ olyan kvadratikus alak, amely csak tisztán négyzetes tagokat tartalmaz, nevezetesen

$$
Q(x)=b_{1} x_{1}^{2}+b_{2} x_{2}^{2}+\ldots+b_{n} x_{n}^{2}
$$

Akkor az együtthatók elójelei alapján a következö eseteket különböztetjük meg.

- Ha minden $k$ indexre $b_{k}>0$, akkor Q pozitív definit.

- Ha mindegyik $b_{k} \geq 0$, és van olyan $j$, amelyre $b_{j}=0$, akkor $Q$ pozitív szemidefinit. 
- Ha az együtthatók között elöfordul pozitív és negatív is, akkor Q indefinit.

Természetesen analóg eseteket fogalmazhatunk meg a negatív definit, illetve negatív szemidefinit esetekre is. Tételünk alapján a továbbiakban azt vizsgáljuk, hogy egy kvadratikus alak hogyan transzformálható olyanná, amelyben csak tiszta négyzetes tagok állnak (teljes négyzetté alakítás $n$-dimenzióban).

\subsection{Definitség a sajátértékek alapján}

Tekintsük a $Q: \mathbb{R}^{n} \rightarrow \mathbb{R}$ kvadratikus alakot, és jelölje $B$ a hozzá tartozó $n \times n$-es szimmetrikus mátrixot.

A szimmetrikus mátrixok spektráltétele (lásd előző fejezet) szerint az $\mathbb{R}^{n}$ térnek létezik a $B$ sajátvektoraiból álló

$$
v_{1}, \ldots, v_{n}
$$

ortonormált bázisa, amelyre

$$
B v_{1}=\lambda_{1} v_{1} \quad \ldots \quad B v_{n}=\lambda_{n} v_{n} .
$$

Ebben a bázisban a $B$ mátrix a következő $\hat{B}$ diagonális alakot ölti:

$$
\hat{B}=\left[\begin{array}{ccc}
\lambda_{1} & \ldots & 0 \\
& \ddots & \\
0 & \ldots & \lambda_{n}
\end{array}\right]
$$

Itt $\lambda_{1}, \ldots, \lambda_{n}$ a $B$ megfelelő sajátvektorai (nem feltétlenül mind különbözőek). Könnyen látható, hogy ezzel a diagonális mátrix-szal a kvadratikus alak tiszta négyzetes alakú lesz. Ugyanis a tér bármely $y=y_{1} v_{1}+\ldots+y_{n} v_{n}$ vektorára

$$
\langle y, \hat{B} y\rangle=\lambda_{1} y_{1}^{2}+\ldots+\lambda_{n} y_{n}^{2}
$$

Ezen észrevétel alapján a következő tételt fogalmazzuk meg.

33.10 Tétel. Tekintsük a $Q$ kvadratikus alakot, és jelentse $B$ a hozzá tartozó szimmetrikus mátrixot, azaz

$$
Q(x)=\langle x, B x\rangle
$$

minden $x \in \mathbb{R}^{n}$ esetén. Tekintsük a $B$ sajátértékeit.

- Ha minden sajátérték pozitív, akkor Q pozitív definit.

- Ha minden sajátérték nemnegatív, és van köztük nulla, akkor Q pozitív szemidefinit. 
- Ha minden sajátérték negatív, akkor Q negatív definit.

- Ha minden sajátérték nempozitív, és van köztük nulla, akkor Q negatív szemidefinit.

- Ha van pozitív és negatív sajátérték is, akkor Q indefinit.

Bizonyítás. Az eddigiek alapján csak annyit kell igazolnunk, hogy $B$ és $\hat{B}$ definitsége megegyezik. Ha a korábbi jelöléseinket használva $S$ jelenti a $B$ sajátvektoraiból álló mátrixot, akkor

$$
\langle y, \hat{B} y\rangle=\left\langle y, S^{T} B S y\right\rangle=\langle S y, B S y\rangle=\langle x, B x\rangle
$$

a tér bármely $y$ vektorára. Mivel $S$ invertálható, azért $x=S y$ a tér minden vektorát előállítja.

\subsection{Példa.}

Állapítsuk meg a $Q(x)=2 x_{1}^{2}+5 x_{1} x_{3}+5 x_{2}^{2}-x_{3} x_{1}-x_{3}^{2}$ kvadratikus alak definitségét! Világos, hogy a hozzá tartozó $B$ szimmetrikus mátrix a következő:

$$
B=\left[\begin{array}{rrr}
2 & 0 & 2 \\
0 & 5 & 0 \\
2 & 0 & -1
\end{array}\right]
$$

amelynek karakterisztikus polinomja

$$
\operatorname{det}(B-\lambda E)=(5-\lambda)(\lambda-3)(\lambda+2) .
$$

Ennek gyökei, azaz a $B$ sajátértékei

$$
\lambda_{1}=5 \quad \lambda_{2}=3 \quad \text { és } \quad \lambda_{3}=-2
$$

Ezek között pozitív és negatív is előfordul, ezért $Q$ indefinit.

\section{Otthoni tanuláshoz}

1. A Feladatgyújtemény-1 II/1 és II/7 szakaszok kidolgozott példáinak feldolgozása.

2. Házi feladatok: a II/1 szakasz 1.6.4, 1.7.3, 1.8.3, 1.8.5, 1.9.3, 1.9.4, 1.9.5, továbbá a II/7 szakasz 7.1.4, 7.2.3, 7.3.4, 7.3.5, 7.4.4, 7.4.5 feladatai.

3. Tankönyv-1 12.5, 15.8 és 15.9 szakaszai. 


\section{4.}

TÖBBVÁLTOZÓS FÜGGVÉNYEK DERIVÁLÁSA 



\subsection{Differenciálhatóság}

Többváltozós függvény differenciálhatóságát egy pontban úgy értelmezzük, hogy a függvény az adott pont valamely környezetében "jól közelíthető" a pontbeli érintővel. A jó közelíthetôség fogalmához van szükség az alábbi definícióra.

34.1 Definíció. Azt mondjuk, hogy az $r: \mathbb{R}^{n} \rightarrow \mathbb{R}^{m}$ kisrendú az origóban, ha

$$
\lim _{n \rightarrow \infty} \frac{\left\|r\left(v_{n}\right)\right\|}{\left\|v_{n}\right\|}=0
$$

bármely $v_{n} \neq 0$ és $\left\|v_{n}\right\| \rightarrow 0$ sorozatra.

34.2 Definíció. Tekintsük az $f: \mathbb{R}^{n} \rightarrow \mathbb{R}^{m}$ függvényt, amely értelmezve van az $x$ pont egy környezetében. Azt mondjuk, hogy $f$ differenciálható az $x$ pontban, ha található olyan $A: \mathbb{R}^{n} \rightarrow \mathbb{R}^{m}$ lineáris leképezés (azaz $m \times n$-es mátrix), hogy bármely $v$ vektorra

$$
f(x+v)=f(x)+A v+r(v),
$$

ahol az $r$ függvény kisrendú az orogóban. Ebben az esetben az $A$ leképezést az $f$ deriváltjának nevezzük az $x$ pontban. Jelölése $A=f^{\prime}(x)$.

FIGYELEM! Gondoljuk meg, hogy $n=m=1$ esetén ez a definíció ekvivalens a korábban tanultakkal!

Nem világos a definícióból, hogy a derivált egyértelmúen meghatározott, azaz csak egyetlen olyan $A$ lineáris leképezés létezhet, amely kielégíti a fenti definíciót. Erre ad választ az alábbi állítás.

34.3 Állítás. A derivált egyértelmúen meghatározott.

Bizonyítás. Tegyük fel, hogy az $A$ és $B$ lineáris leképezések egyaránt eleget tesznek a definíció követelményeinek, azaz bármely $v$ vektor esetén

$$
\begin{aligned}
& f(x+v)=f(x)+A v+r(v) \\
& f(x+v)=f(x)+B v+q(v),
\end{aligned}
$$

ahol $r$ és $q$ kisrendú függvények. Ekkor a $C=B-A$ jelöléssel a $C v=r(v)-q(v)=o(v)$ egyenlőséghez jutunk, amely ugyancsak kisrendú függvény. Tehát tetszőleges $v \neq 0$ vektor mellet

$$
\frac{\|C v\|}{\|v\|}=\frac{\left\|C\left(\frac{1}{n} v\right)\right\|}{\left\|\frac{1}{n} v\right\|}=\frac{\left\|o\left(\frac{1}{n} v\right)\right\|}{\left\|\frac{1}{n} v\right\|} \rightarrow 0,
$$

ha $n \rightarrow \infty$. Ez azt jelenti, hogy $C v=0$, azaz $C=B-A=0$. 
Könnyű meggondolni, hogy ha egy $f$ függvény differenciálható egy $x$ pontban, akkor ott folytonos is.

34.4 Állítás. Ha $f$ lineáris, akkor minden $x \in X$ pontban differenciálható, és $f^{\prime}(x)=f$.

Bizonyítás. Valóban, alkalmazzuk a definíciót az $A=f, r=0$ szereposztás mellett.

34.5 Példa. Tekintsük az $\mathbb{R}^{n}$ téren a

$$
Q(x)=\langle x, B x\rangle
$$

kvadratikus alakot, ahol $B n \times n$-es szimmetrikus mátrix. Megmutatjuk, hogy $Q$ minden $x$ pontban differenciálható éspedig $Q^{\prime}(x)=2 B x$.

Valóban, bármely $v$ vektor mellett

$$
\begin{aligned}
f(x+v)-f(x) & =\langle x+v, B(x+v)\rangle-\langle x, B x\rangle \\
& =\langle v, B x\rangle+\langle x, B v\rangle+\langle v, B v\rangle \\
& =\langle v, 2 B x\rangle+\langle v, B v\rangle
\end{aligned}
$$

hiszen $B$ szimmetrikus. Állításunk igazolásához tehát elég belátni, hogy $\langle v, B v\rangle$ kisrendû. Ez azonban egyszerúen látható a

$$
|\langle v, B v\rangle| \leq\|B\| \cdot\|v\|^{2}
$$

Cauchy-Schwarz-féle egyenlőtlenségből.

Az alábbiakban összefoglaljuk a derivált legfontosabb tulajdonságait. A következő állítás egyszerúen adódik a definícióból.

34.6 Állítás. Tegyük fel, hogy az $f$ és g függvények egyaránt differenciálhatók az $x$ pontban, és legyen $\lambda$ tetszóleges skalár. Akkor $f+g$, illetve $\lambda f$ is differenciálhatók az $x$ pontban, és

$$
\begin{aligned}
(f+g)^{\prime}(x) & =f^{\prime}(x)+g^{\prime}(x) \\
(\lambda f)^{\prime}(x) & =\lambda f^{\prime}(x)
\end{aligned}
$$




\subsection{Láncszabály}

Tekintsük az $f: \mathbb{R}^{n} \rightarrow \mathbb{R}^{m}$, valamint a $g: \mathbb{R}^{m} \rightarrow \mathbb{R}^{k}$ függvényeket. Tegyük fel, hogy $x$ belsô pontja az $f$ értelmezési tartományának, és $f(x)$ is belsô pontja a $g$ értelmezési tartományának.

34.7 Tétel. (Láncszabály) Ha $f$ differenciálható az x pontban, továbbá g differenciálható az $f(x)$ pontban, akkor $g \circ f$ is differenciálható az x pontban, éspedig

$$
(g \circ f)^{\prime}(x)=g^{\prime}(f(x)) f^{\prime}(x) .
$$

Bizonyítás. A feltételeink azt jelentik, hogy

$$
f(x+v)=f(x)+f^{\prime}(x) v+r(v),
$$

illetve

$$
g(f(x)+u)=g(f(x))+g^{\prime}(f(x)) u+q(u),
$$

ahol $r$ és $q$ egyaránt kisrendûk. Ha most $v$ tetszóleges, akkor az $u=f(x+v)-f(x)$ jelöléssel

$$
\begin{aligned}
g(f(x+v))-g(f(x)) & =g^{\prime}(f(x)) u+q(u) \\
& =g^{\prime}(f(x))(f(x+v)-f(x))+q(u) \\
& =g^{\prime}(f(x))\left(f^{\prime}(x) v+r(v)\right)+q(u) \\
& =g^{\prime}(f(x)) f^{\prime}(x) v+g^{\prime}(f(x)) r(v)+q(u) .
\end{aligned}
$$

Azt kell igazolni, hogy $g^{\prime}(f(x)) r(v)+q(u)$ kisrendű $v$ szerint. Ezt tagonként mutatjuk meg. Az elsố tagra ez a megállapítás nyilvánvaló, hiszen

$$
\lim _{v \rightarrow 0} \frac{\left\|g^{\prime}(f(x)) r(v)\right\|}{\|v\|} \leq\left\|g^{\prime}(f(x))\right\| \lim _{v \rightarrow 0} \frac{\|r(v)\|}{\|v\|}=0 .
$$

A második tag kisrendû $u$ szerint. Ez azonban $v$ szerint is igaz, ugyanis

$$
\frac{\|q(u)\|}{\|v\|}= \begin{cases}0, & \text { ha } f(x+v)-f(x)=0 \\ \frac{\|q(u)\|}{\|u\|} \frac{\|f(x+v)-f(x)\|}{\|v\|}, & \text { ha } f(x+v)-f(x) \neq 0\end{cases}
$$

Mivel az $f$ folytonossága miatt $v \rightarrow 0$ esetén $u \rightarrow 0$ is fennáll, azért

$$
\lim _{v \rightarrow 0} \frac{\|q(u)\|}{\|v\|}=0
$$

hiszen az

$$
\frac{\|f(x+v)-f(x)\|}{\|v\|}=\frac{\left\|f^{\prime}(x) v+r(v)\right\|}{\|v\|} \leq\left\|f^{\prime}(x)\right\|+\frac{\|r(v)\|}{\|v\|}
$$

tört korlátos. 
Esetünkben $g^{\prime}(f(x)) k \times m$, illetve $f^{\prime}(x) m \times n$ méretû́ mátrixok, és ennek megfelelően a $(g \circ f)^{\prime}(x)$ szorzatmátrix $k \times n$ méretú.

\subsection{Parciális deriváltak}

Természetes kérdés, hogy hogyan határozható meg a derivált mátrixa.

Tekintsünk egy olyan $f: \mathbb{R}^{n} \rightarrow \mathbb{R}^{m}$ függvényt, amely differenciálható az $x \in X$ pontban. Ekkor $f^{\prime}(x), m \times n$ méretú mátrix. Mivel

$$
f=\left[\begin{array}{c}
f_{1} \\
f_{2} \\
\vdots \\
f_{m}
\end{array}\right]
$$

ahol az $f_{i}$ függvények az $f$ koordinátafüggvényei, azárt az $f^{\prime}(x)$ mátrix sorait az egyes koordinátafüggvények deriváltjai alkotják, azaz

$$
f^{\prime}(x)=\left[\begin{array}{c}
f_{1}^{\prime}(x) \\
f_{2}^{\prime}(x) \\
\vdots \\
f_{m}^{\prime}(x)
\end{array}\right]
$$

Elegendő tehát megvizsgálni, hogy hogyan állítható elő egyetlen koordinátafüggvény deriváltjának a mátrixa.

Megjegyezzükk, hogy az $f$ differenciálhatóságából következik a koordinátafüggvények differenciálhatósága, és fordítva, ha az $f$ minden koordinátafüggvénye differenciálható, akkor $f$ is differenciálható.

Legyen tehát $f: \mathbb{R}^{n} \rightarrow \mathbb{R}$ és jelölje $e_{1}, \ldots, e_{n}$ az ortonormált bázist.

34.8 Definíció. Legyen $x$ az $f$ értelmezési tartományának belső pontja. Azt mondjuk, hogy $f$ parciálisan differenciálható az $i$-ik változó szerint az $x$ pontban, ha létezik a

$$
\lim _{t \rightarrow 0} \frac{1}{t}\left(f\left(x+t e_{i}\right)-f(x)\right)=f_{i}^{\prime}(x)
$$

határérték, és ez véges. Az $f_{i}^{\prime}(x)$ határértéket az $f$ parciális deriváltjának nevezzük az $x$ pontban.

Ha bevezetjük a $g(t)=f\left(x+t e_{i}\right)$ függvényt a számegyenesen, akkor az $f$ parciális differenciálhatósága az $i$-ik változó szerint az $x$ pontban azt jelenti, hogy $g$ differenciálható a 0 pontban, és $g^{\prime}(0)=f_{i}^{\prime}(x)$. Ennek az a szemléletes tartalma, hogy az $f$ 
függvényt csak az $i$-ik változójában vizsgáljuk, a többi változót rögzített konstansnak tekintjük az $x$ pontban. Parciális deriváltakra néha az

$$
f_{i}^{\prime}(x)=\frac{\partial f}{\partial x_{i}}(x)
$$

jelölés is használatos.

34.9 Tétel. Ha $f$ differenciálható az x pontban, akkor $f$ minden változója szerint parciálisan differenciálható az x pontban, éspedig

$$
f_{i}^{\prime}(x)=f^{\prime}(x) e_{i}
$$

minden $i=1, \ldots, n$ indexre.

Bizonyítás. Valóban, a differenciálhatóság miatt

$$
\frac{1}{t}\left(f\left(x+t e_{i}\right)-f(x)\right)=\frac{1}{t}\left(f^{\prime}(x)\left(t e_{i}\right)+r\left(t e_{i}\right)\right)=f^{\prime}(x) e_{i}+\frac{r\left(t e_{i}\right)}{t},
$$

amiből $t \rightarrow 0$ mellett azonnal adódik az állítás.

34.10 Példa. Megmutatjuk, hogy a fenti tételünk nem fordítható meg. Nevezetesen nem nehéz példát mutatni olyan függvényre, amely valamely pontban parciálisan differenciálható az összes változója szerint, de a függvény még csak nem is folytonos abban a pontban. Tekintsük például a síkon az

$$
f(x, y)= \begin{cases}\frac{2 x y}{x^{2}+y^{2}}, & \text { ha } x^{2}+y^{2} \neq 0 \\ 0, & \text { különben }\end{cases}
$$

függvényt. Könnyen látható, hogy $f_{1}^{\prime}(0,0)=f_{2}^{\prime}(0,0)=0$, azonban $f$ nem folytonos az origóban. Valóban, $f$ a koordinátatengelyek mentén zérus, míg a $45^{\circ}$-os egyenes mentén 1 , így $f$ az origó bármely környezetében egyaránt felveszi a 0 és az 1 értékeket is.

\subsection{A Jacobi-mátrix és a gradiens}

A parciális deriváltak segítségével a derivált mátrixa már előállítható. Tekintsük az $f: \mathbb{R}^{n} \rightarrow \mathbb{R}^{m}$ függvényt, amely differenciálható az $x$ pontban. Jelöljék $f_{1}, \ldots, f_{m}$ az $f$ koordinátafüggvényeit. Ekkor

$$
f^{\prime}(x)=\left[\begin{array}{cccc}
\left(f_{1}\right)_{1}^{\prime}(x) & \left(f_{1}\right)_{2}^{\prime}(x) & \ldots & \left(f_{1}\right)_{n}^{\prime}(x) \\
\left(f_{2}\right)_{1}^{\prime}(x) & \left(f_{2}\right)_{2}^{\prime}(x) & \ldots & \left(f_{2}\right)_{n}^{\prime}(x) \\
\vdots & \vdots & & \vdots \\
\left(f_{m}\right)_{1}^{\prime}(x) & \left(f_{m}\right)_{2}^{\prime}(x) & \ldots & \left(f_{m}\right)_{n}^{\prime}(x)
\end{array}\right]
$$


Ezt az $m \times n$ méretû́ $f^{\prime}(x)$ mátrixot szokás az $f$ függvény Jacobi-mátrixának is nevezni az $x$ pontban.

34.11 Példa. Legyenek például

$$
f_{1}\left(x_{1}, x_{2}, x_{3}\right)=2 x_{1} x_{2} x_{3} \quad f_{2}\left(x_{1}, x_{2}, x_{3}\right)=x_{1}^{2}+x_{2}^{3}+x_{3}^{4}
$$

Ekkor az $f=\left(f_{1}, f_{2}\right): \mathbb{R}^{3} \rightarrow \mathbb{R}^{2}$ függvény Jacobi-mátrixa az $x=\left(x_{1}, x_{2}, x_{3}\right)$ pontban:

$$
f^{\prime}(x)=\left[\begin{array}{ccc}
2 x_{2} x_{3} & 2 x_{1} x_{3} & 2 x_{1} x_{2} \\
2 x_{1} & 3 x_{2}^{2} & 4 x_{3}^{3}
\end{array}\right]
$$

amely egy $2 \times 3$ méretû́ mátrix.

Speciáliasan az $m=1$ esetben az $f: \mathbb{R}^{n} \rightarrow \mathbb{R}$ függvény Jacobi-mátrixa (deriváltja) egyetlen sorból áll, nevezetesen

$$
f^{\prime}(x)=\left[f_{1}^{\prime}(x), \ldots, f_{n}^{\prime}(x)\right]
$$

Ezt a deriváltat az irodalomban néha az $f$ gradiens vektorának nevezik az $x$ pontban.

34.12 Példa. Tekintsük például azt az $f: \mathbb{R}^{2} \rightarrow \mathbb{R}^{2}$ függvényt, amely a sík pontjainak poláris koordinátáit derékszögú koordinátákra váltja, azaz

$$
f(r, \alpha)=\left[\begin{array}{c}
r \cos \alpha \\
r \sin \alpha
\end{array}\right],
$$

és legyen $g: \mathbb{R}^{2} \rightarrow \mathbb{R}^{3}$ a következő leképezés

$$
g(x, y)=\left[\begin{array}{c}
x^{2}-x y \\
y^{2}-x y \\
2 x y
\end{array}\right]
$$

Határozzuk meg a $(g \circ f)^{\prime}(1, \pi / 3)$ mátrixot. Ekkor

$$
f^{\prime}(r, \alpha)=\left[\begin{array}{rr}
\cos \alpha & -r \sin \alpha \\
\sin \alpha & r \cos \alpha
\end{array}\right],
$$

továbbá

$$
g^{\prime}(x, y)=\left[\begin{array}{cc}
2 x-y & -x \\
-y & 2 y-x \\
2 y & 2 x
\end{array}\right] .
$$


Ezért a kompozíció függvény differenciálhatósága alapján:

$$
\begin{aligned}
& (g \circ f)^{\prime}(1, \pi / 3)= \\
& =\left[\begin{array}{cc}
1-\sqrt{3} / 2 & -1 / 2 \\
-\sqrt{3} / 2 & \sqrt{3}-1 / 2 \\
\sqrt{3} & 1
\end{array}\right] \cdot\left[\begin{array}{cc}
1 / 2 & -\sqrt{3} / 2 \\
\sqrt{3} / 2 & 1 / 2
\end{array}\right] \\
& =\left[\begin{array}{cc}
1 / 2-\sqrt{3} / 2 & 1 / 2-\sqrt{3} / 2 \\
3 / 2-\sqrt{3} / 2 & 1 / 2+\sqrt{3} / 2 \\
\sqrt{3} & 1
\end{array}\right],
\end{aligned}
$$

amely természetesen $3 \times 2$ méretû mátrix.

34.13 Speciális eset. A láncszabály gyakran előforduló speciális esete a következő. Legyenek $f_{1}, \ldots, f_{n}: \mathbb{R} \rightarrow \mathbb{R}$ differenciálható függvények és $f(t)=\left(f_{1}(t), \ldots, f_{n}(t)\right)$. Legyen továbbá $g: \mathbb{R}^{n} \rightarrow \mathbb{R}$ olyan függvény, amelynek a parciális deriváltjai léteznek és folytonosak. Ekkor

$$
(g \circ f)^{\prime}(t)=\sum_{k=1}^{n} g_{k}^{\prime}\left(f_{1}(t), \ldots, f_{n}(t)\right) f_{k}^{\prime}(t)
$$

Valóban, a $g$ Jacobi-mátrixa (gradiense) ekkor egyetlen sorból áll:

$$
g^{\prime}(f(t))=\left[g_{1}^{\prime}(f(t)), \ldots, g_{n}^{\prime}(f(t))\right]
$$

míg az $f$ Jacobi-mátrixa egyetlen oszlopot tartalmaz:

$$
f^{\prime}(t)=\left[\begin{array}{c}
f_{1}^{\prime}(t) \\
\vdots \\
f_{n}^{\prime}(t)
\end{array}\right]
$$

A két vektor skaláris szorzatából adódik a fenti formula.

34.14 Példa. Tekintsünk egy $g: \mathbb{R}^{n} \rightarrow \mathbb{R}$ függvényt, amelynek a parciális deriváltjai léteznek és folytonosak, és legyen $v \in \mathbb{R}^{n}$ adott vektor. Ekkor az

$$
F(t)=g(a+t v)
$$

egyváltozós függvény deriváltja a fentiek szerint:

$$
F^{\prime}(t)=\left\langle g^{\prime}(a+t v), v\right\rangle
$$

speciálisan $F^{\prime}(0)=\left\langle g^{\prime}(a), v\right\rangle$. 


\section{Otthoni tanuláshoz}

1. A Feladatgyûjjtemény-1 III/1 szakasza kidolgozott példáinak feldolgozása.

2. Házi feladatok: a III/1 szakasz 1.1.4, 1.1.5, 1.1.6, 1.1.7, 1.4.3, 1.4.4, 1.4.5, 1.5.3, 1.5.4, 1.6.3, 1.6.5 feladatai.

3. Tankönyv-1 15.3, 15.4, 15.6, 16.1 és 16.2 szakaszai. 


\section{5.}

MÁSODRENDÜ DERIVÁLTAK 



\subsection{Folytonos differenciálhatóság}

Tegyük fel, hogy $f: \mathbb{R}^{n} \rightarrow \mathbb{R}$ differenciálható az $x$ pont egy környezetében. Tekintsük az $f^{\prime}: \mathbb{R}^{n} \rightarrow \mathbb{R}^{n}$ deriváltfüggvényt, és tegyük fel, hogy ez folytonos az $x$ pont adott környezetében. Ilyenkor azt mondjuk, hogy $f$ folytonosan differenciálható.

35.1 Tétel. Az f függvény akkor és csak akkor folytonosan differenciálható az x pontban, ha a parciális deriváltjai az x egy környezetében léteznek, és folytonosak az $x$ pontban.

Bizonyítás. Először a szükségességet igazoljuk. Tekintsük az $x$ pontot, és legyen $\varepsilon>0$. Ekkor az $f^{\prime}$ folytonossága miatt létezik olyan $\delta>0$, hogy $\|x-y\|<\delta$ esetén $\left\|f^{\prime}(x)-f^{\prime}(y)\right\|<\varepsilon$. Ekkor a 34.9 Állítás folytán a parciális deriváltak léteznek, és

$$
\begin{aligned}
\left|f_{i}^{\prime}(x)-f_{i}^{\prime}(y)\right| & =\left|\left(f^{\prime}(x)-f^{\prime}(y)\right) e_{i}\right| \\
& \leq\left\|f^{\prime}(x)-f^{\prime}(y)\right\|<\varepsilon
\end{aligned}
$$

bármely $i=1, \ldots, n$ mellett. Ez éppen a parciális deriváltak folytonosságát jelenti.

Térjünk rá az elegendőség bizonyítására. Legyen adott az $x$ pont és $\varepsilon>0$. Ekkor a parciális deriváltak folytonossága alapján van olyan $\delta>0$, hogy minden $x, y \in X$, $\|x-y\|<\delta$ esetén

$$
\left|f_{i}^{\prime}(x)-f_{i}^{\prime}(y)\right|<\varepsilon / n
$$

bármely $i=1, \ldots, n$ mellett. (Ez nyilván megtehetô úgy, hogy minden $i$ esetén választunk egy ilyen $\delta$ számot, majd az így kapott $n$ darab $\delta$ közül kiválasztjuk a legkisebbet.)

Válasszunk ezután egy olyan $v$ vektort, amelyre $\|v\|<\delta$. Ha $v$ koordinátái rendre a $v_{1}, \ldots, v_{n}$ valós számok, úgy vezessük be a

$$
v^{i}=\left[\begin{array}{c}
v_{1} \\
\vdots \\
v_{i} \\
0 \\
\vdots \\
0
\end{array}\right],
$$

és $v^{0}=0$ jelöléseket $(i=1, \ldots, n)$. Ekkor a Lagrange-féle középérték-tétel szerint vannak olyan $0<t_{i}<1$ számok, hogy

$$
\begin{aligned}
f(x+v)-f(x) & =\sum_{i=1}^{n}\left(f\left(x+v^{i}\right)-f\left(x+v^{i-1}\right)\right)= \\
& =\sum_{i=1}^{n} f_{i}^{\prime}\left(x+v^{i-1}+t_{i} v_{i} e_{i}\right) v_{i}= \\
\sum_{i=1}^{n} f_{i}^{\prime}(x) v_{i} & +\sum_{i=1}^{n}\left(f_{i}^{\prime}\left(x+v^{i-1}+t_{i} v_{i} e_{i}\right)-D_{i} f(x)\right) v_{i} .
\end{aligned}
$$


Itt a második szumma kisrendû $v \rightarrow 0$ esetén, hiszen

$$
\frac{1}{\|v\|}\left|\sum_{i=1}^{n}\left(f_{i}^{\prime}\left(x+v^{i-1}+t_{i} v_{i} e_{i}\right)-f_{i}^{\prime}(x)\right) v_{i}\right| \leq \sum_{i=1}^{n} \frac{\varepsilon}{n} \frac{\left|v_{i}\right|}{\|v\|}<\varepsilon .
$$

Ez éppen azt jelenti, hogy $f$ differenciálható az $x$ pontban. Mivel $f^{\prime}(x)=$ $\left[f_{1}^{\prime}(x), \ldots, f_{n}^{\prime}(x)\right]$, azért a koordinátafüggvények folytonossága miatt $f^{\prime}$ is folytonos is az $x$ pontban.

\subsection{Másodrendű deriváltak}

Tekintsük az $f: \mathbb{R}^{n} \rightarrow \mathbb{R} n$-változós differenciálható függvényt, és tegyük fel, hogy az $f^{\prime}: \mathbb{R}^{n} \rightarrow \mathbb{R}^{n}$ derivált függvény is differenciálható az $x$ pont egy környezetében. Ekkor beszélhetünk az $f$ függvény másodrendû deriváltjáról. A Jacobi-mátrixhoz hasonlóan elkészítjük az

$$
f^{\prime}(x)=\left[\begin{array}{r}
f_{1}^{\prime}(x) \\
\vdots \\
f_{n}^{\prime}(x)
\end{array}\right]
$$

koordinátafüggvényeinek parciális deriváltjait, amelyeket az $f$ másodrendû parciális deriváltjainak nevezünk. Ekkor az $i$-ik, majd $k$-ik változók szerinti másodrendú parciális derivált

$$
\frac{\partial^{2} f}{\partial x_{i} \partial x_{k}}\left(x_{1}, \ldots, x_{n}\right)=f_{i k}^{\prime \prime}\left(x_{1}, \ldots, x_{n}\right)
$$

Hasonlóan, az $x_{i}$ változó szerinti másodrendú parciális derivált:

$$
\frac{\partial^{2} f}{\partial x_{i}^{2}}\left(x_{1}, \ldots, x_{n}\right)=f_{i i}^{\prime \prime}\left(x_{1}, \ldots, x_{n}\right)
$$

Ekkor az $f^{\prime \prime}(x)$ másodrendû derivált a következő $n \times n$ méretû́ mátrix

$$
f^{\prime \prime}(x)=\left[\begin{array}{cccc}
f_{11}^{\prime \prime}(x) & f_{12}^{\prime \prime}(x) & \ldots & f_{1 n}^{\prime \prime}(x) \\
f_{21}^{\prime \prime}(x) & f_{22}^{\prime \prime}(x) & \ldots & f_{2 n}^{\prime \prime}(x) \\
\vdots & \vdots & & \vdots \\
f_{n 1}^{\prime \prime}(x) & f_{n 2}^{\prime \prime}(x) & \ldots & f_{n n}^{\prime \prime}(x)
\end{array}\right]
$$

amelyet az $f$ függvény Hesse-mátrixának is nevezünk az $x$ pontban. 


\subsection{Young-tétel}

35.2 Példa. Könnyen látható, hogy például az $f(x, y)=2 x^{3}+5 x^{2} y^{3}-\ln \left(x y^{2}\right)$ függvény esetében

$$
\begin{aligned}
f_{1}^{\prime}(x, y) & =6 x^{2}+10 x y^{3}-1 / x \\
f_{2}^{\prime}(x, y) & =15 x^{2} y^{2}-1 / y^{2} \\
f_{11}^{\prime \prime}(x, y) & =12 x+10 y^{3}-1 / x^{2} \\
f_{22}^{\prime \prime}(x, y) & =30 x^{2} y-2 / y^{3} \\
f_{12}^{\prime \prime}(x, y) & =f_{21}^{\prime \prime}(x, y)=30 x y^{2}
\end{aligned}
$$

A fenti példánkban azt láthatjuk, hogy az $f$ függvény vegyes parciális deriváltjai megegyeznek. A következó tételünk azt fogalmazza meg, hogy ez nem véletlen, viszonylag általános feltételek mellett ez mindig érvényes.

35.3 Tétel. (Young) Ha az $f$ n-változós függvény másodrendú parciális deriváltfüggvényei léteznek és folytonosak, akkor a Hesse-mátrix szimmetrikus, azaz.

$$
f_{i k}^{\prime \prime}(x)=f_{k i}^{\prime \prime}(x)
$$

bármely $i, k=1,2, \ldots, n$ indexekre.

Bizonyítás. Nyilván elég a bizonyítást a kétváltozós esetre elvéegezni. Tegyük fel, hogy $f: \mathbb{R}^{2} \rightarrow \mathbb{R}$ kétszer folytonosan differenciálható az $(x, y)$ pontban. Legyen $v \in \mathbb{R}$ rögzített, ás tekintsük az

$$
F(t)=f(t, y+v)-f(t, y), \quad G(t)=f(x+v, t)-f(x, t)
$$

függvényeket. A feltevésünk szerint ezek differenciálhatók az $x$, illetve az y pont egy környezetében, és

$$
F(x+v)-F(x)=G(y+v)-G(y) .
$$

A Lagrange-féle középértéktétel szerint található olyan $0<t<1$ szám, amelyre

$$
F(x+v)-F(x)=F^{\prime}(x+t v) v,
$$

azaz az $F$ definíciójára tekintettel

$$
\begin{aligned}
F(x+v)-F(x) & =\left(f_{1}^{\prime}(x+t v, y+v)-f_{1}^{\prime}(x+t v, y)\right) v \\
& =\left(D_{12} f(x+t v, y) v+o(v)\right) v
\end{aligned}
$$


Innen a második derivált folytonossága alapján

$$
\lim _{v \rightarrow 0} \frac{F(x+v)-F(x)}{v^{2}}=f_{12}^{\prime \prime}(x, y) .
$$

Teljesen hasonló gondolatmenettel az adódik, hogy

$$
\lim _{v \rightarrow 0} \frac{G(y+v)-G(y)}{v^{2}}=f_{21}^{\prime \prime}(x, y) .
$$

Ezért a 35.1 egyenlőségből azonnal következik, hogy

$$
f_{12}^{\prime \prime}(x, y)=f_{21}^{\prime \prime}(x, y)
$$

azaz a második derivált szimmetrikus mátrix.

35.4 Példa. Legyen például $f: \mathbb{R}^{3} \rightarrow \mathbb{R}$ az

$$
f(x, y, z)=2 x^{2} y+x y z-y^{2} z^{2}
$$

formulával értelmezett függvény. Ellenőrizzük, hogy a második derivált az $(x, y, z)$ helyen az

$$
f^{\prime \prime}(x, y, z)=\left[\begin{array}{ccc}
4 y & 4 x+z & y \\
4 x+z & -2 z^{2} & x-4 y z \\
y & x-4 y z & -2 y^{2}
\end{array}\right]
$$

szimmetrikus mátrix.

\subsection{Taylor-formula}

Tekintsünk egy $f: \mathbb{R}^{n} \rightarrow \mathbb{R}$ függvényt.

35.5 Tétel. Tegyük fel, hogy $f$ kétszer folytonosan differenciálható az x pont egy környezetében. Akkor

$$
f(x+v)=f(x)+f^{\prime}(x) v+\frac{1}{2}\left\langle v, f^{\prime \prime}(x) v\right\rangle+o\left(\|v\|^{2}\right),
$$

ahol

$$
\lim _{v \rightarrow 0} \frac{o\left(\|v\|^{2}\right)}{\|v\|^{2}}=0
$$


Bizonyítás. Legyen adott $\varepsilon>0$. A második derivált folytonossága miatt az $x$ pontnak van olyan környezete, amelyben

$$
\left\|f^{\prime \prime}(x+v)-f^{\prime \prime}(x)\right\|<\varepsilon .
$$

Vezessük be a számegyenesen a

$$
g(t)=f(x+t v)
$$

függvényt. Mivel ekkor $g$ egy elsőfokú függvény és az $f$ kompozíciójaként áll elő, a láncszabály alapján világos, hogy $g$ kétszer folytonosan differenciálható az origó egy környezetében, és

$$
g^{\prime}(0)=f^{\prime}(x) v \quad g^{\prime \prime}(0)=\left\langle v, f^{\prime \prime}(x) v\right\rangle .
$$

Alkalmazzuk a $g$ függvényre az egyváltozós Taylor-formulát, akkor található olyan $t \in$ $[0,1]$ pont, amelyre

$$
g(1)=g(0)+g^{\prime}(0)+\frac{1}{2} g^{\prime \prime}(t) .
$$

Mivel $g^{\prime \prime}(t)=\left\langle v, f^{\prime \prime}(x+t v) v\right\rangle$, innen azt kapjuk, hogy

$$
f(x+v)=f(x)+f^{\prime}(x) v+\frac{1}{2}\left\langle v, f^{\prime \prime}(x) v\right\rangle+\frac{1}{2}\left\langle v,\left(f^{\prime \prime}(x+t v)-f^{\prime \prime}(x)\right) v\right\rangle .
$$

Itt az $r(v)=\frac{1}{2}\left\langle v,\left(f^{\prime \prime}(x+t v)-f^{\prime \prime}(x)\right) v\right\rangle$ jelöléssel világos, hogy

$$
|r(v)| \leq \frac{1}{2}\left\|f^{\prime \prime}(x+t v)-f^{\prime \prime}(x)\right\| \cdot\|v\|^{2}<\varepsilon\|v\|^{2}
$$

Ez éppen azt jelenti, hogy $r(v)=o\left(\|v\|^{2}\right)$, amit igazolnunk kellett.

\section{Otthoni tanuláshoz}

1. A Feladatgyűjtemény-1 III/2 szakasza kidolgozott példáinak feldolgozása.

2. Házi feladatok: a III/2 szakasz 2.2.2, 2.2.3, 2.2.4, 2.2.6, 2.2.8, 2.2.10, 2.2.11, 2.2.14, 2.2.15, 2.2.16 feladatai.

3. Tankönyv-1 17 . fejezet. 



\section{6.}

TÖBBVÁLTOZÓS SZÉLSŐÉRTÉK 



\subsection{Lokális szélsőérték}

36.1 Definíció. Az $\mathbb{R}^{n}$ tér origó középpontú egységgömbjén a

$$
B=\left\{x \in \mathbb{R}^{n}:\|x\| \leq 1\right\}
$$

halmazt értjük. Világos, hogy valamely $a \in \mathbb{R}^{n}$ pont körüli $r>0$ sugarú gömb az

$$
a+r B=\left\{x \in \mathbb{R}^{n}:\|x-a\| \leq r\right\}
$$

formulával adható meg.

Tekintsünk egy $f: \mathbb{R}^{n} \rightarrow \mathbb{R}$ függvényt. Azt mondjuk, hogy az értelmezési tartomány valamely $a$ pontja az $f$ lokális minimumhelye, ha található olyan $\varepsilon>0$, hogy

$$
f(x) \geq f(a)
$$

az értelmezési tartomány minden olyan $x$ pontjában, amelyre $x \in a+\varepsilon B$, azaz $\|x-a\| \leq$ $\varepsilon$.

Hasonlóan értelmezzük a lokális maximum fogalmát, és értelemszerúen fogalmazhatjuk meg a globális minimum és maximum definícióját is.

\subsection{Elsőrendű szükséges feltétel}

Tegyük fel a továbbiakban, hogy az $f: \mathbb{R}^{n} \rightarrow \mathbb{R}$ függvény differenciálható az $a$ pont egy környezetében.

36.2 Tétel. Ha az $a \in \mathbb{R}^{n}$ pont az $f$ lokális minimumhelye, akkor $f_{1}^{\prime}(a)=\ldots=f_{n}^{\prime}(a)=$ 0 .

Tekintsük ugyanis az $e_{k} \in \mathbb{R}^{n}$ egységvektorokat, és jelölje

$$
g(t)=f\left(a+t e_{k}\right) .
$$

A lokális minimum definíciója alapján a $g$ függvénynek lokális minimumhelye van a $t=0$ pontban, másrészt a Láncszabály szerint $g$ differenciálható is, éspedig

$$
g^{\prime}(t)=\left\langle f^{\prime}\left(a+t e_{k}\right), e_{k}\right\rangle .
$$

Innen adódik, hogy minden $k=1, \ldots, n$ indexre:

$$
0=g^{\prime}(0)=\left\langle f^{\prime}(a), e_{k}\right\rangle=f_{k}^{\prime}(a)
$$


A fenti tétel szerint a parciális deriváltakra felírt egyenletrendszer megoldásai között kereshetjük a függvény szélsőértékhelyeit. Ez az egyenletrendszer azonban (az egyváltozós esethez hasonlóan) csak szükséges feltételt fogalmaz meg. Például az

$$
f(x, y)=x^{3} y^{2}
$$

függvény esetében az $f_{1}^{\prime}(x, y)=f_{2}^{\prime}(x, y)=0$ egyenletrendszer egyik megoldása $(x, y)=$ $(0,0)$. Ekkor

$$
f(0,0)=0
$$

de ez nem lehet szélsőérték, hiszen $f$ az origó körüli bármilyen sugarú gömb belsejében felvesz pozitív és negatív értékeket is.

Szükségünk van tehát másodrendû (szükséges, illetve elégséges) feltételekre.

\subsection{Másodrendú szükséges feltétel}

A továbbiakban feltesszük, hogy $f: \mathbb{R}^{n} \rightarrow \mathbb{R}$ kétszer folytonosan differenciálható az $a$ pont egy környezetében.

36.3 Tétel. Tegyük fel, hogy a az f lokális minimuhelye. Akkor az $f$ Hesse-mátrixa az a helyen pozitív szemidefinit.

Bizonyítás. Legyen $v \in \mathbb{R}^{n}$ tetszőleges, és vezessük be a korábbiakban vizsgált

$$
g(t)=f(a+t v)
$$

függvényt. A feltételünk szerint $g$ kétszer differenciálható, és ha $a$ az $f$ lokális minimumhelye, akkor 0 a $g$ lokális minimumhelye, ezért $g^{\prime \prime}(0) \geq 0$. Ez azt jelenti, hogy

$$
0 \leq g^{\prime \prime}(0)=\left\langle f^{\prime \prime}(a) v, v\right\rangle
$$

Mivel $v \in \mathbb{R}^{n}$ tetszőleges volt, ez éppen azt jeleneti, hogy a Hesse-mátrix pozitív szemidefinit.

Ez a tételünk még nem ad elégséges (csak szükséges) feltételt a szélsőértékre, elég, ha az

$$
f(x, y)=x^{5}+y^{4}
$$

függvényre gondolunk. A $(0,0)$ pontban a parciális deriváltak nullák és a Hesse-mátrix is a nulla mátrix (tehát egyszerre pozitív és negatív szemidefinit), de ez a pont nem szélsőérték.

Természetesen a tételünkkel analóg állítást fogalmazhatunk meg lokális maximumhely esetére is. 


\subsection{A szélsőérték elégséges feltétele}

Tegyük fel újra, hogy az $f: \mathbb{R}^{n} \rightarrow \mathbb{R}$ függvény kétszer folytonosan differenciálható az $a$ pont egy környezetében.

36.4 Tétel. Tegyük fel, hogy az a pontban az $f$ parciális deriváltak nullák, és itt az $f^{\prime \prime}(a)$ Hesse-mátrix pozitív definit. Akkor a az f lokális minimumhelye.

Bizonyítás. A Taylor-formula alapján (ld. 35.5Tétel) az $a$ valamely környezetében

$$
f(a+v)-f(a)=\frac{1}{2}\left\langle v, f^{\prime \prime}(a) v\right\rangle+o\left(\|v\|^{2}\right)
$$

Jelölje $\lambda$ az $f^{\prime \prime}(a)$ mátrix legkisebb sajátértékét, akkor a feltételünk szerint $\lambda$ pozitív, továbbá

$$
\left\langle v, f^{\prime \prime}(a) v\right\rangle \geq \lambda\|v\|^{2}
$$

minden $v$ vektor mellett. Legyen $\delta>0$ olyan, hogy bármely $\|v\|<\delta$ esetén

$$
\left|\frac{o\left(\|v\|^{2}\right)}{\|v\|^{2}}\right|<\frac{\lambda}{3} .
$$

Ezeket a 36.1 egyenlőségbe visszahelyettesítve azt kapjuk, hogy

$$
f(a+v)-f(a) \geq \frac{\lambda}{6}\|v\|^{2}>0,
$$

hacsak $\|v\|<\delta, v \neq 0$. Ez éppen azt jelenti, hogy a az $f$ lokális (szigorú) minimumhelye.

Magától értetődően a tételünkben az $f^{\prime \prime}(a)$ negatív definitsége lokális maximumot jelent.

\subsection{A szélsőérték meghatározása}

Egy $n$-változós függvény szélsőértékeinek meghatározásához tehát a következő lépéseket kell elvégeznünk:

1. Határozzuk meg a parciális deriváltakat

2. Mindegyik parciális deriváltat tegyük egyenlővé nullával, és oldjuk meg az így keletkező egyenletrendszert

3. Ezen helyek mindegyikén állítsuk elő a függvény Hesse-mátrixát

4. Ha egy adott helyen a Hesse-mátrix pozitív definit, akkor az a függvény lokális minimumhelye 
5. Ha egy adott helyen a Hesse-mátrix negatív definit, akkor az a függvény lokális maximumhelye

6. Ha egy adott helyen a Hesse-mátrix indefinit, akkor itt a függvénynek nincs szélsőértéke

7. Ha egy adott helyen a Hesse-mátrix szemidefinit, de nem definit, akkor a feladat tételeink alapján nem oldható meg, az eset egyedi vizsgálatot kíván

36.5 Példa. Vegyük elsô példaként az

$$
f(x, y)=x^{4}+y^{2}
$$

függvényt. Az egyetlen hely, ahol a parciális deriváltak nullák az origó. Ebben a pontban a Hesse-mátrix

$$
H=\left[\begin{array}{ll}
0 & 0 \\
0 & 2
\end{array}\right]
$$

amely nyilván pozitív szemidefinit. Világos azonban, hogy az origó a függvény (globális) minimumhelye.

Teljesen hasonló számítást hajthatunk végre, ha a

$$
g(x, y)=-x^{4}+y^{2}
$$

függvényt vizsgáljuk. Ugyanúgy az origó az egyetlen kritikus pont, és a megfelelő Hesse-mátrix is azonos. Ekkor azonban az origó nem lehet szélsőértékhely, hiszen a függvény az origóhoz tetszőlegesen közel felvesz pozitív és negatív értékeket is.

Az ilyen pontot a $g$ függvény nyeregpontjának nevezzük.

Hasonló példákat találhatunk a negatív szemidefinit Hesse-mátrix esetére is.

Mindenesetre megállapíthatjuk, hogy szemidefinit (de nem definit) Hesse-mátrix esetében minden előfordulhat: az adott pont lehet minimum, maximum vagy nyeregpont is.

Tegyük fel ezután, hogy a Hesse-mátrix nem zérus. Ekkor csak az alábbi esetek fordulhatnak elő:

- Ha a Hesse-mátrix pozitív szemidefinit, akkor az adott pontban csak minimum vagy nyeregpont lehet.

- Ha a Hesse-mátrix negatív szemidefinit, akkor az adott pontban csak maximum vagy nyeregpont lehet. 
36.6 Példa. Keressük meg az alábbi függvény szélsőértékeit:

$$
f(x, y, z)=\left(x^{2}-4 y\right) e^{-\left(x+y+z^{2}\right)}
$$

Ekkor az elsőrendú parciális deriváltakra az alábbi egyenletrendszert kapjuk:

$$
\begin{aligned}
& f_{1}^{\prime}(x, y, z)=\left(2 x-x^{2}+4 y\right) e^{-\left(x+y+z^{2}\right)}=0 \\
& f_{2}^{\prime}(x, y, z)=\left(-4-x^{2}+4 y\right) e^{-\left(x+y+z^{2}\right)}=0 \\
& f_{3}^{\prime}(x, y, z)=-2 z\left(x^{2}-4 y\right) e^{-\left(x+y+z^{2}\right)}=0
\end{aligned}
$$

amelynek egyetlen megoldása $(x, y, z)=(-2,2,0)$

Alkalmazzuk ezután a másodrendú feltételünket.

Nem hosszú számolással ellenőrizhetjük, hogy ezen a helyen a Hesse-mátrix a következő lesz:

$$
H=\left[\begin{array}{lll}
6 & 4 & 0 \\
4 & 4 & 0 \\
0 & 0 & 8
\end{array}\right]
$$

A Hesse-mátrixnak megfelelő kvadratikus alak ezért

$$
6 x_{1}^{2}+8 x_{1} x_{2}+4 x_{2}^{2}+8 x_{3}^{2}=2 x_{1}^{2}+4\left(x_{1}+x_{2}\right)^{2}+8 x_{3}^{2} .
$$

Tehát a Hesse-mátrix pozitív definit, ezért a $(-2,2,0)$ pontban az $f$ függvénynek lokális minimuma van.

\section{Otthoni tanuláshoz}

1. A Feladatgyưjitemény-1 III/2 szakasza kidolgozott példáinak feldolgozása.

2. Házi feladatok: a III/2 szakasz 2.2.2, 2.2.3, 2.2.4, 2.2.6, 2.2.8, 2.2.10, 2.2.11, $2.2 .14,2.2 .15,2.2 .16$ feladatai.

3. Tankönyv-1 17. fejezet. 



\section{Irodalmi utalások, kitekintés}

Természetesen tisztában vagyunk azzal, hogy egy három féléves matematika tárgyba jelen tananyagnál többet nem célszerú bepréselni. Ennek ellenére minden tanévben számos olyan érdeklődő hallgatónk akad, akik örömmel hallanának további érdekes feladatokról, nehezebb problémákról, és akik szívesen vállalnának még komolyabb kihívásokat. Számukra készült az alábbi útmutató, ahol megtalálhatják azokat a forrásokat, amelyek feldolgozása során kipróbálhatják magukat.

Analízis, többváltozós függvények: Walter Rudin: A matematikai analízis alapjai, Typotex, Budapest, 2012. (Talán a mai napig a világ legjobb klasszikus analízis tankönyve, nehéz és érdekes feladatokkal.)

Lineáris algebra: Dancs István és Puskás Csaba: Vektorterek, Aula Kiadó, 2005. (Az egyik legjobb magyar nyelvú lineáris algebra tankönyv, kifejezetten a matematikus-közgazdász hallgatók szempontjai szerint szerkesztve.)

Valószínúiségszámítás: Medvedev Péter: Bevezetés a valószínúségszámításba. Letölthető: http://medvegyev.uni-corvinus.hu/kisvalszam.pdf (Szép, és nagyon igényes bevezetés, számos izgalmas közgazdasági, pénzügyi alkalmazással.)

Valószínúségszámítás: Kai Lai Chung: Elementary Probability Theory with Stochastic Processes, Springer-Verlag, New York, Heidelberg, Berlin, 1979. (Örök klasszikus, gyönyörú tárgyalásmód, gondolkodtató feladatok. Fontos magyar vonatkozása, hogy a szerző Pólya György diákja volt a Berkeley egyetemen.)

E könyv szerzője szívesen segít hallgatóinak a források beszerzésében, és nagy örömmel nyújt segítséget azok megértésében, feldolgozásában. 



\section{Matematika előadások}

Hogyan határozhatjuk meg egy vásárló optimális döntését korlátozó feltételek mellett? Milyen árat határozzon meg a termelő a maximális nyereség érdekében? Milyen következtetéseket tudunk levonni egy rendelkezésünkre álló adatsor vizsgálatából?

Ezek olyan típusú kérdések, amelyek a közgazdaságtan alapjainak tanulmányozásakor a mikroökonómiában, a makroökonómiában, vagy a statisztikában gyakran felmerülnek. És ezen kérdések megválaszolásához mindmind matematikai eszközökre, eljárásokra van szükségünk.

Ez a kézikönyv ennek a matematikai eszköztárnak az elsajátításához kíván segítséget nyújtani szigorúan hetekre bontott előadások formájában. 